Supporting Information

\title{
Au- and Pt-Catalyzed Cycloisomerizations of 1,5-Enynes to Cyclohexadienes with a Broad Alkyne Scope
}

\section{(Spectra)}

Jianwei Sun, Matthew P. Conley, Liming Zhang and Sergey A. Kozmin*

Department of Chemistry, University of Chicago

5735 S. Ellis, Chicago, IL 60637 


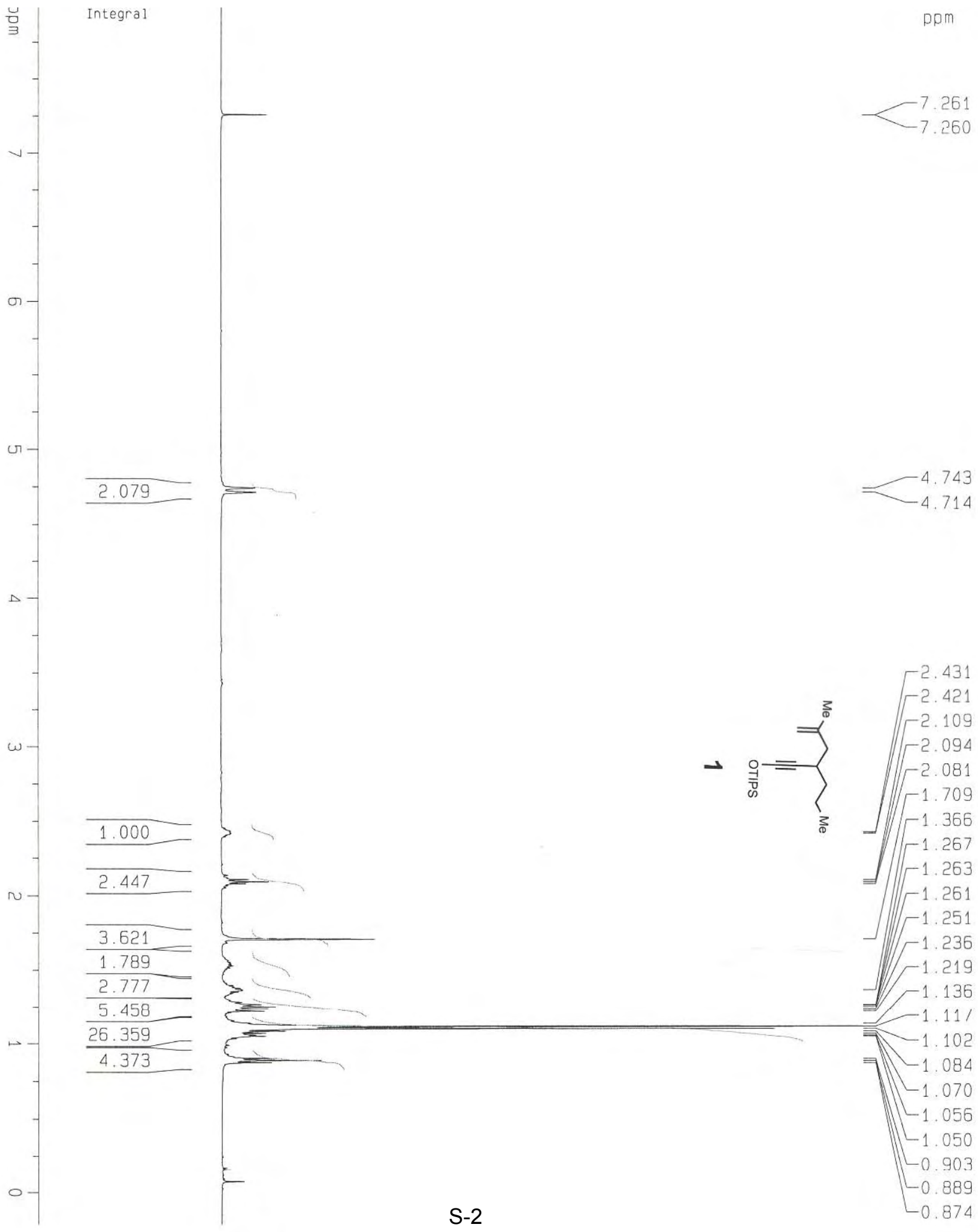




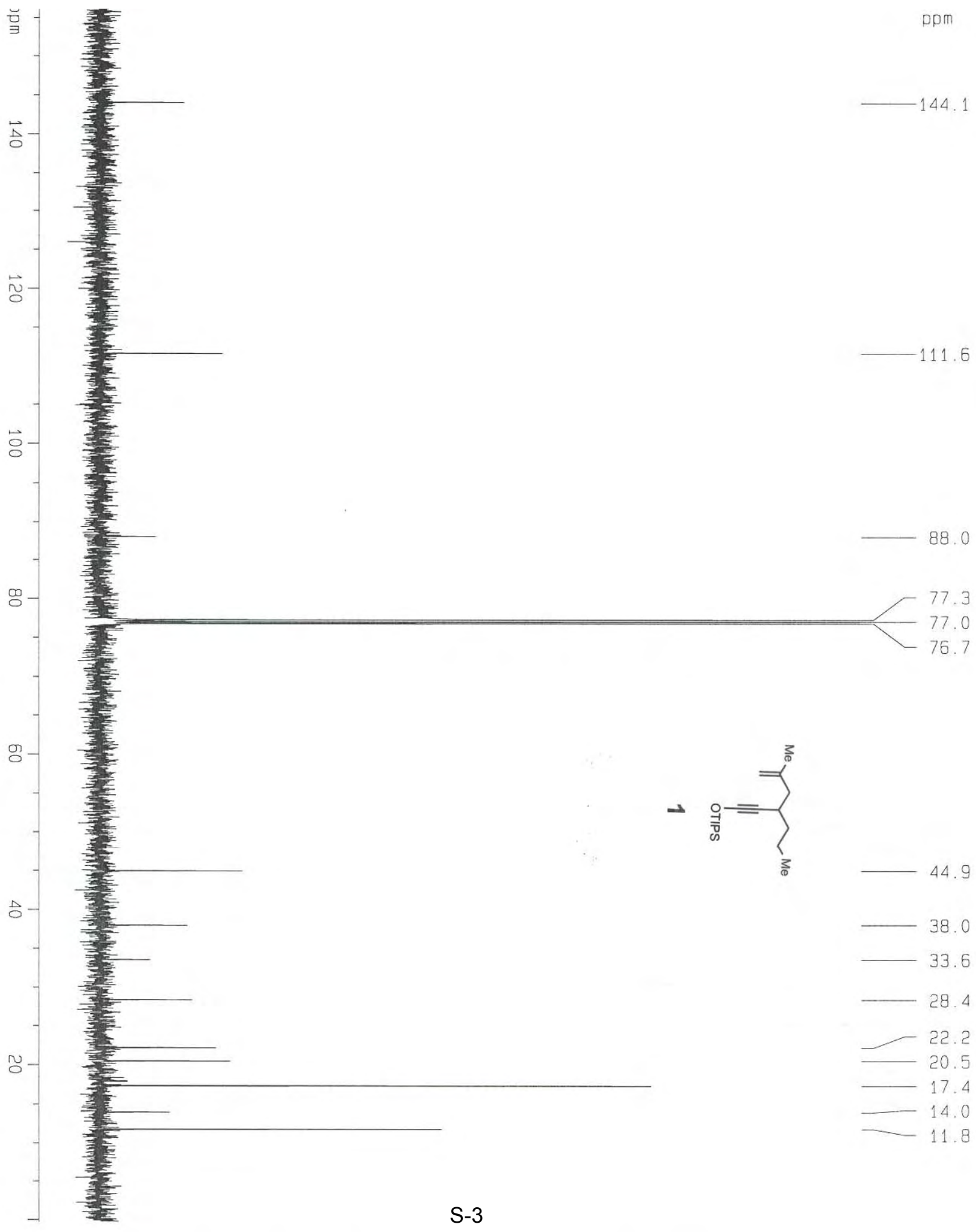




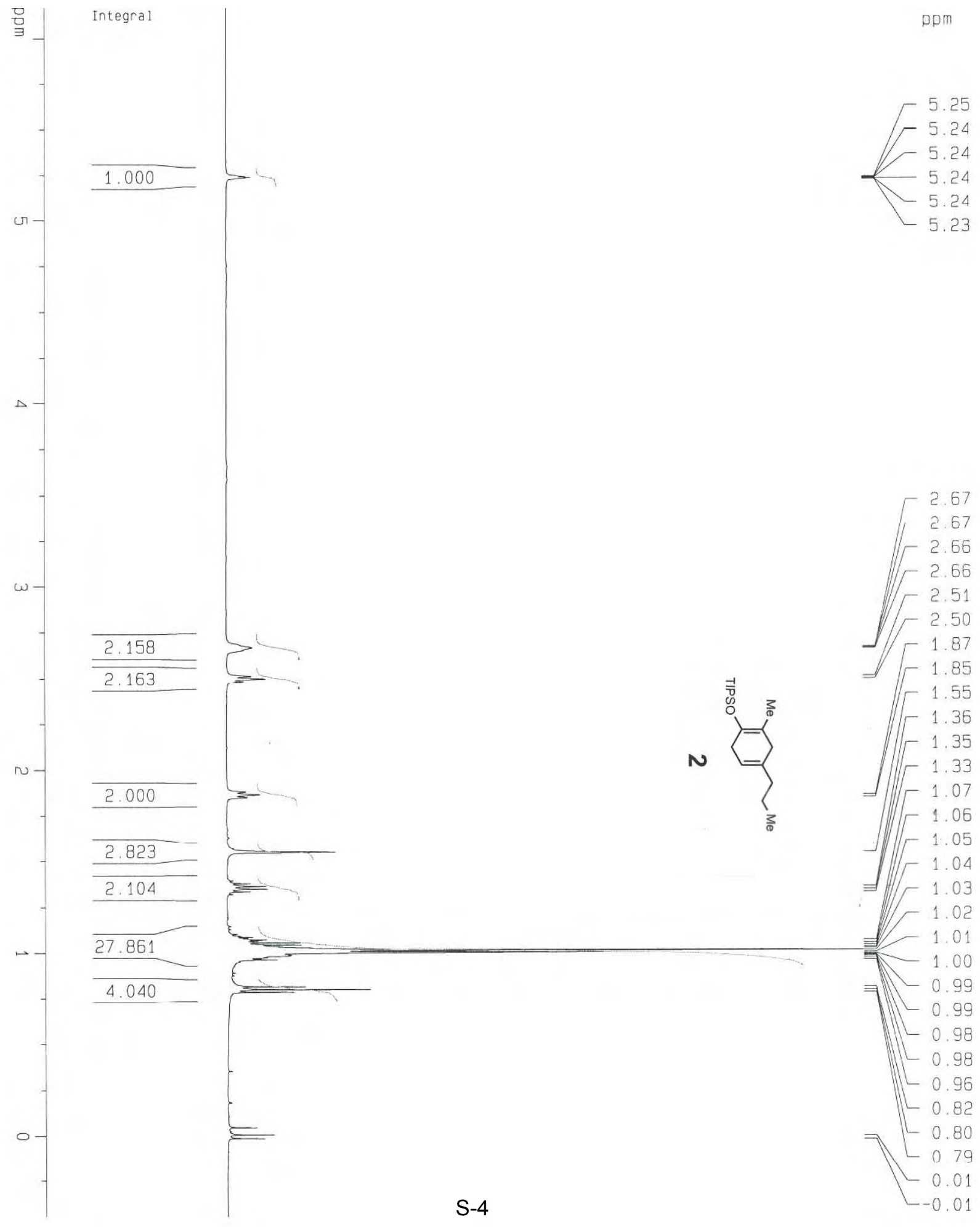




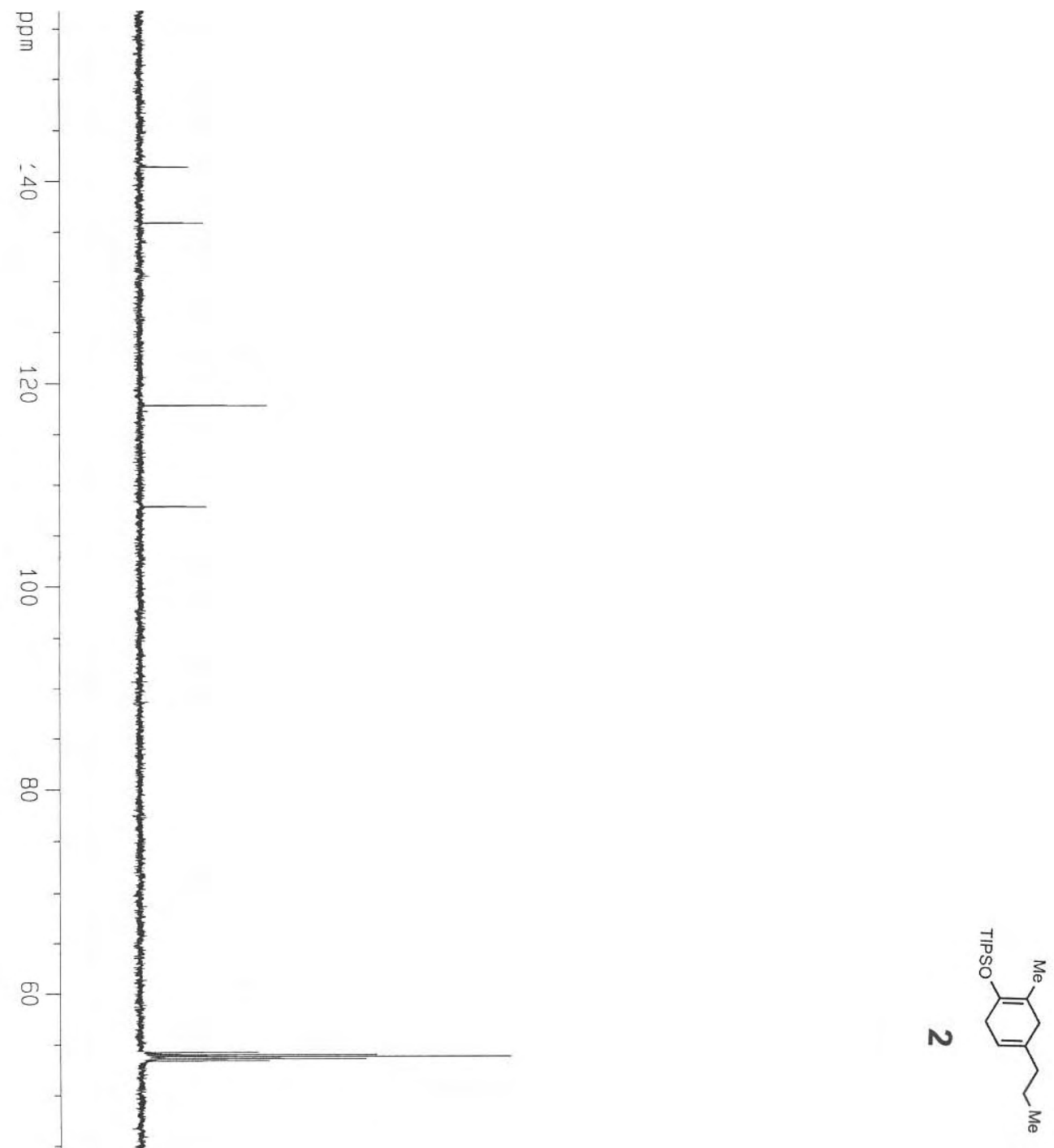

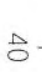

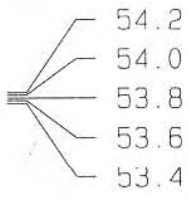

$-39.1$

36.1

32.5

?

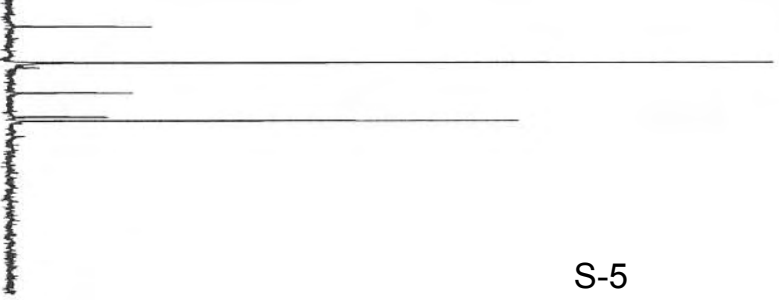

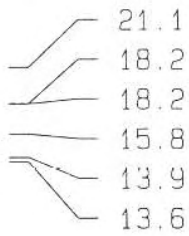




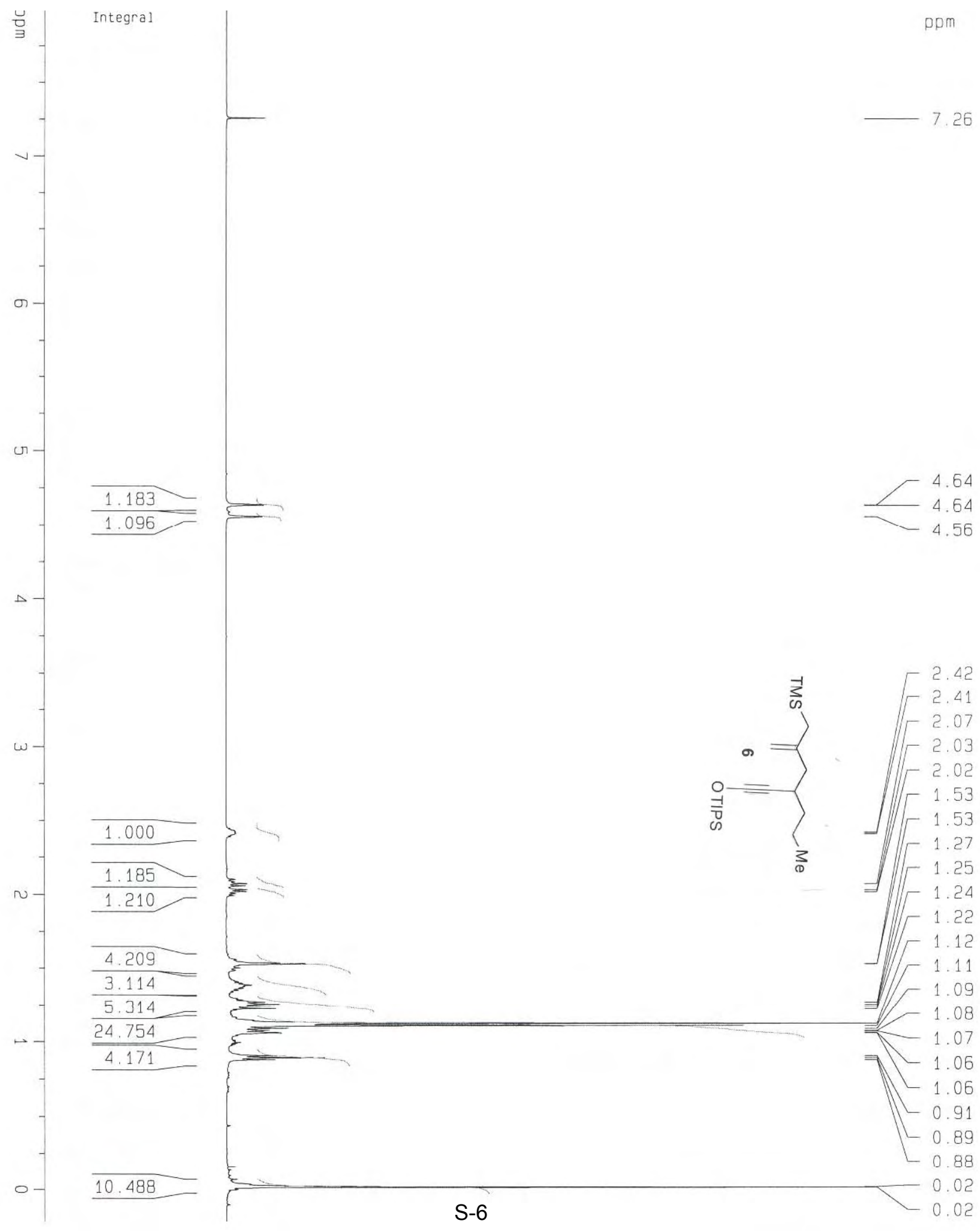



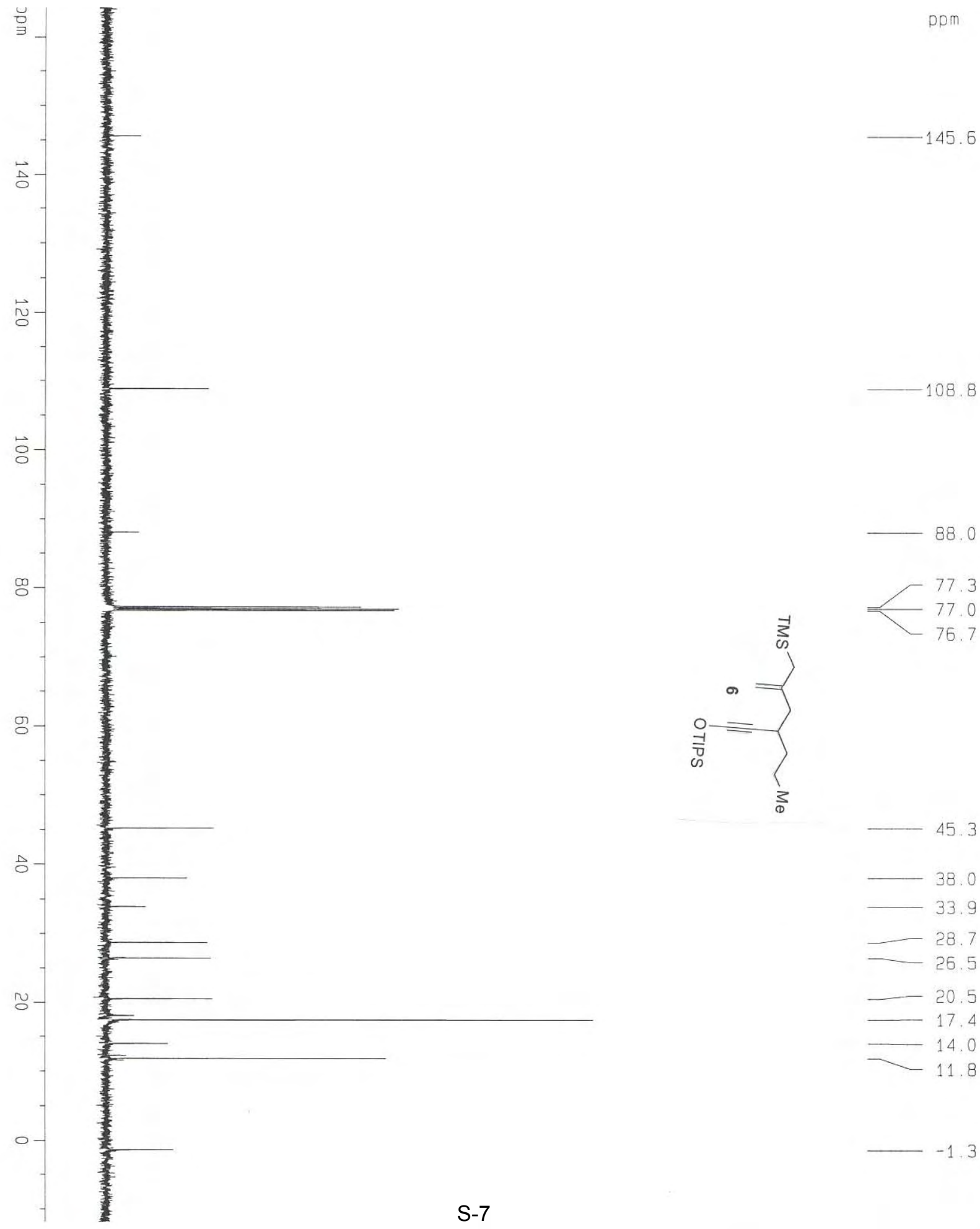

45. 3

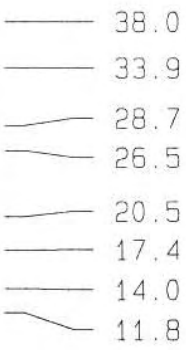




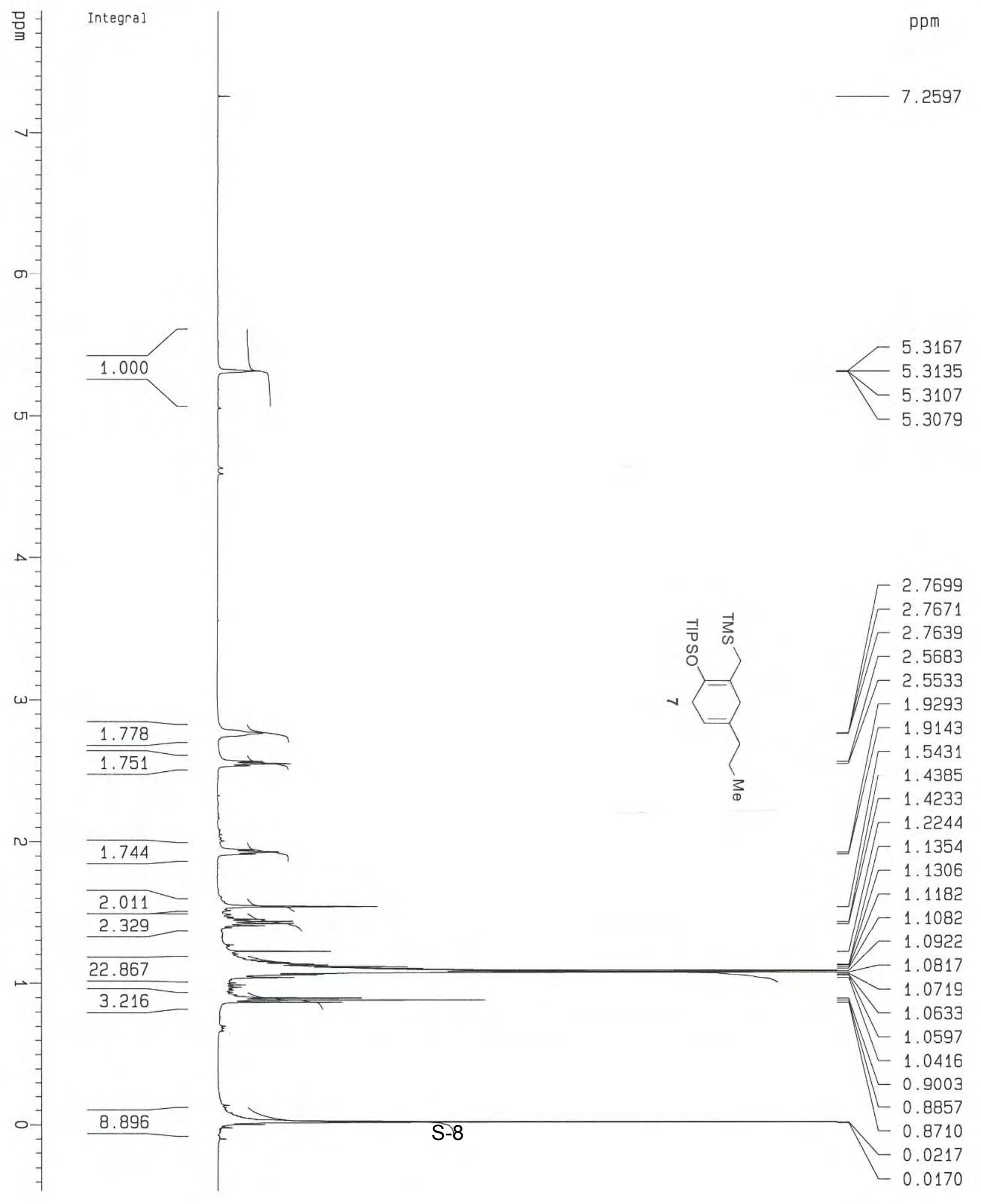



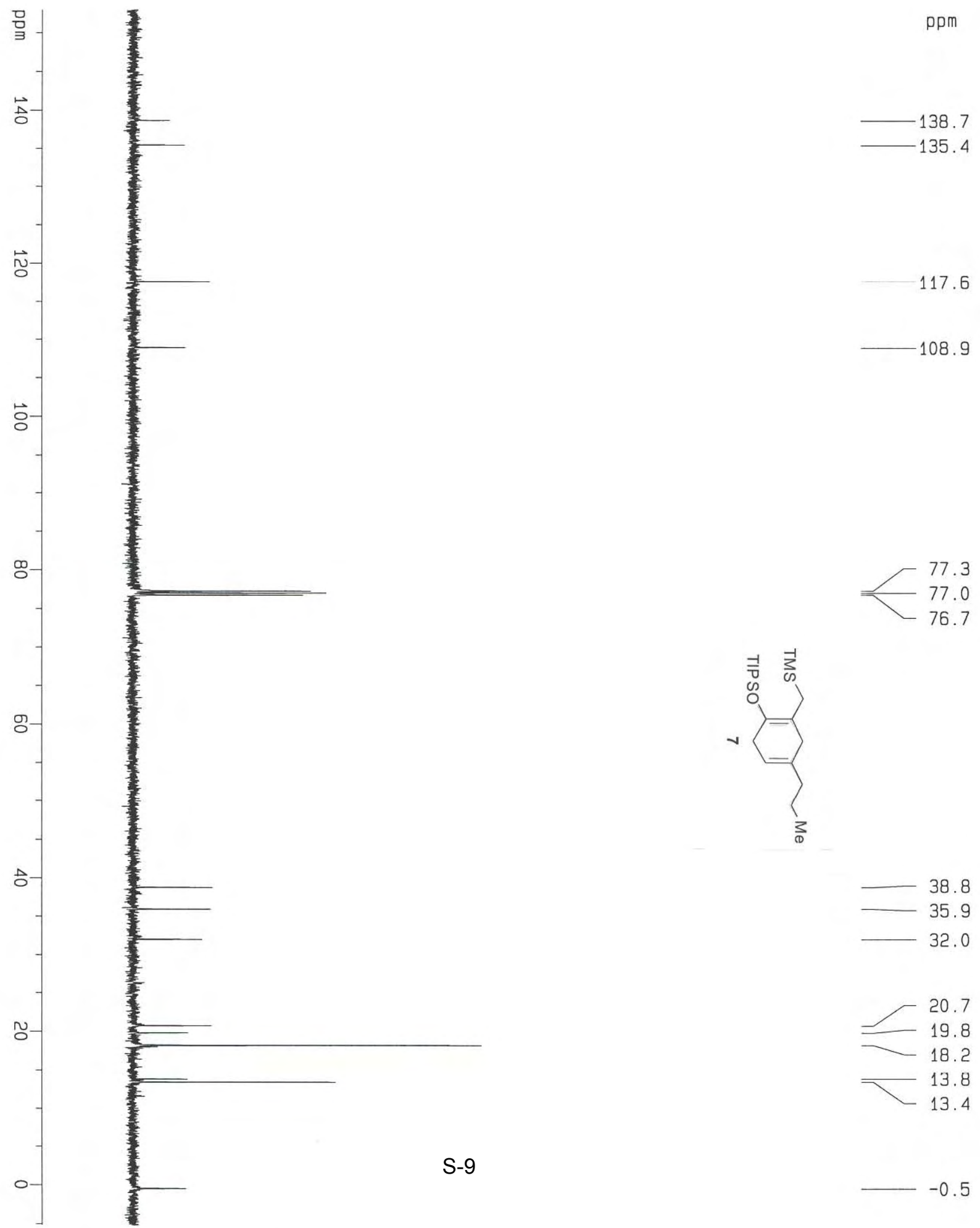

38.8

35.9

32. 0

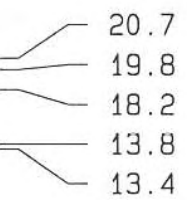

0.7

19.8

18. 2

13.8
13.4

-9 


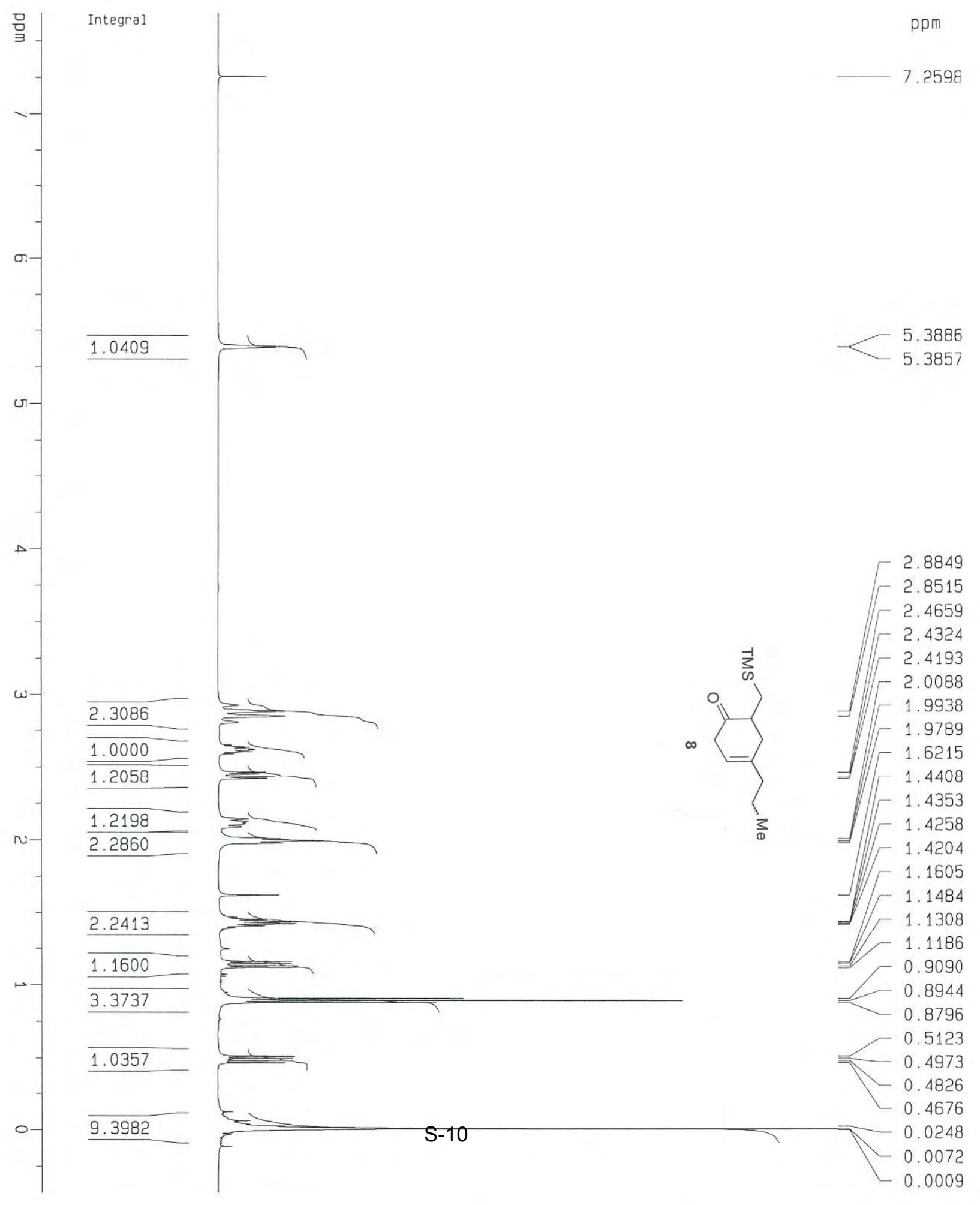



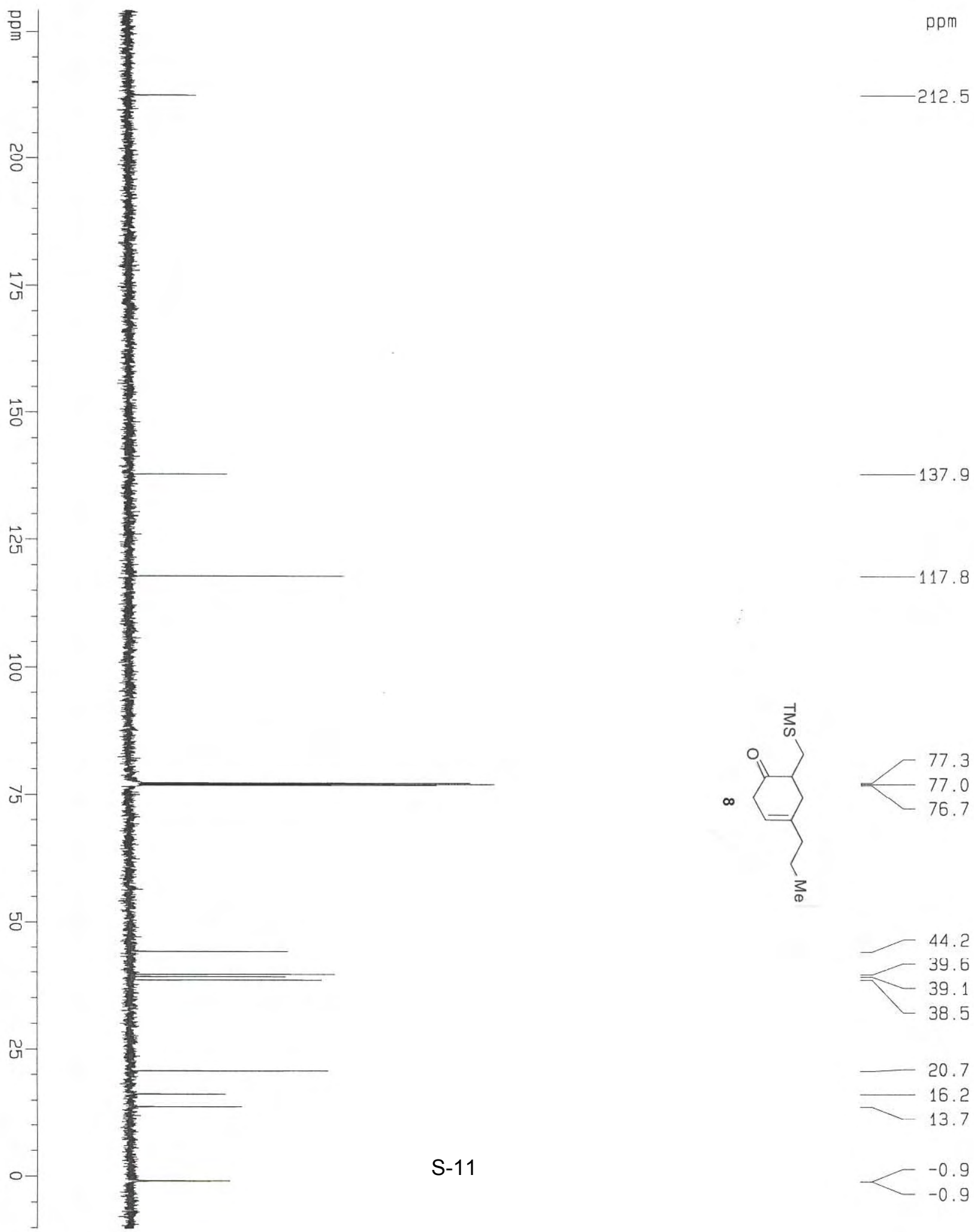

44.2 39.6 39.1 38.5 20.7 16.2 13.7 $\longrightarrow-0.9$ 


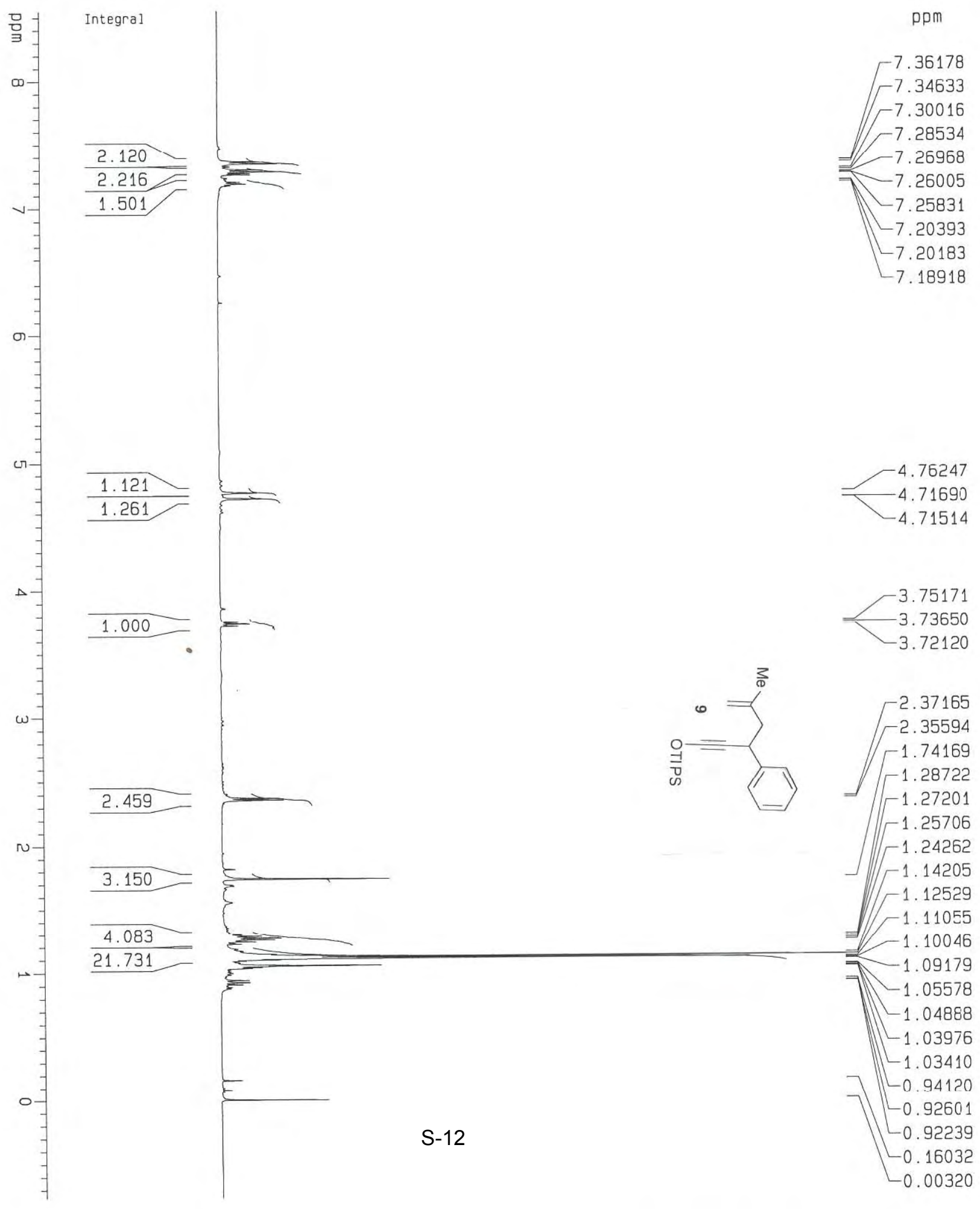



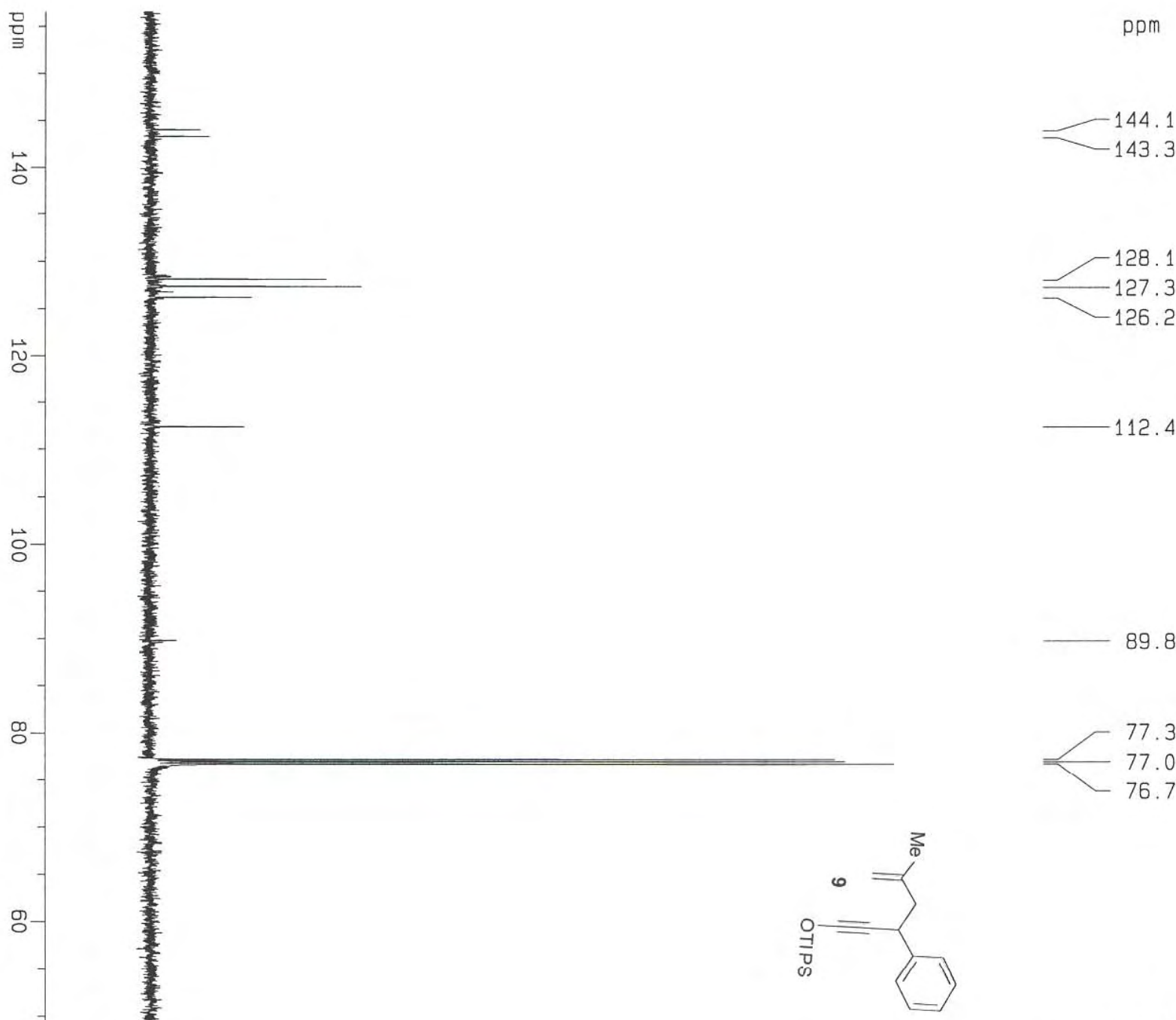


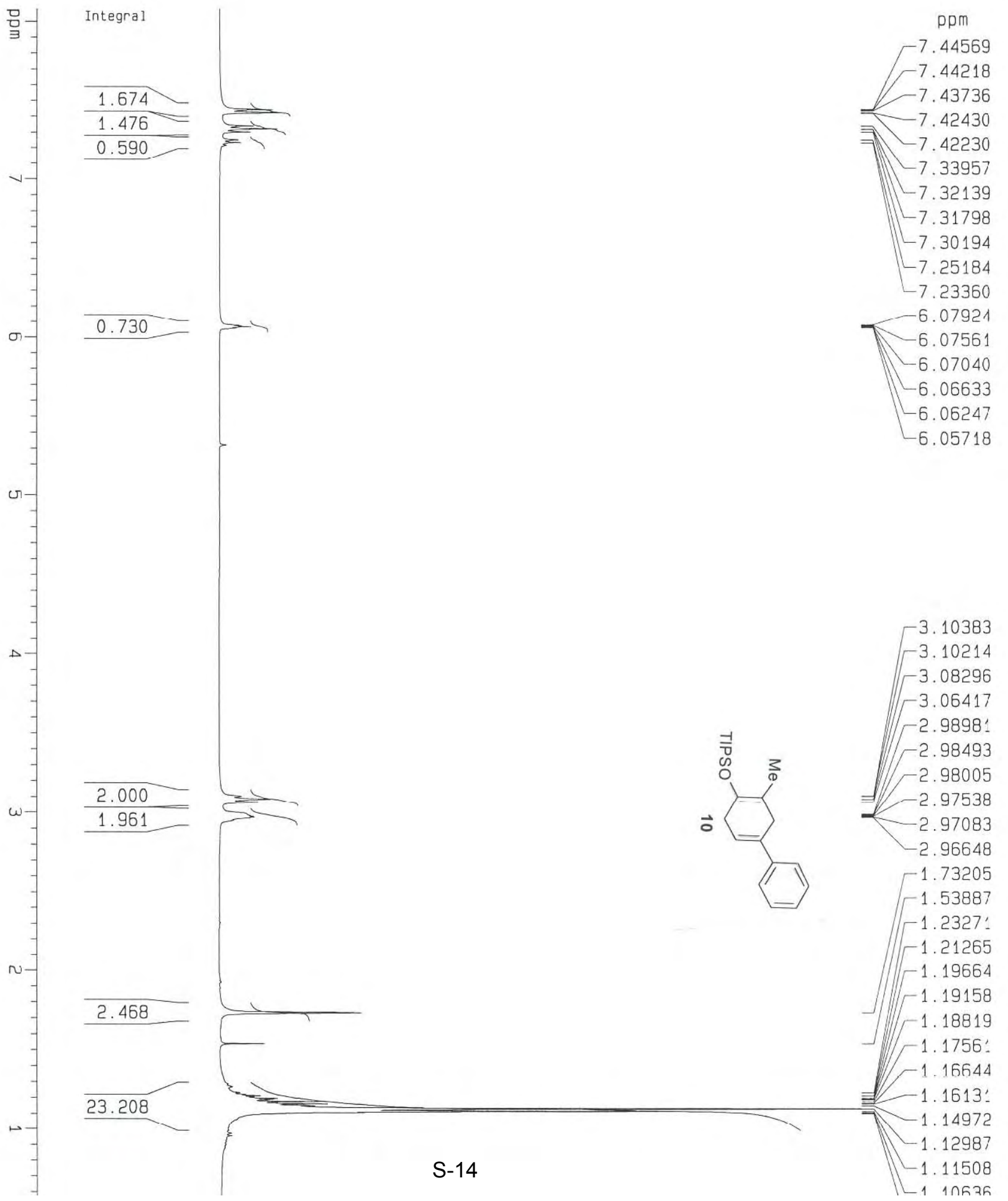




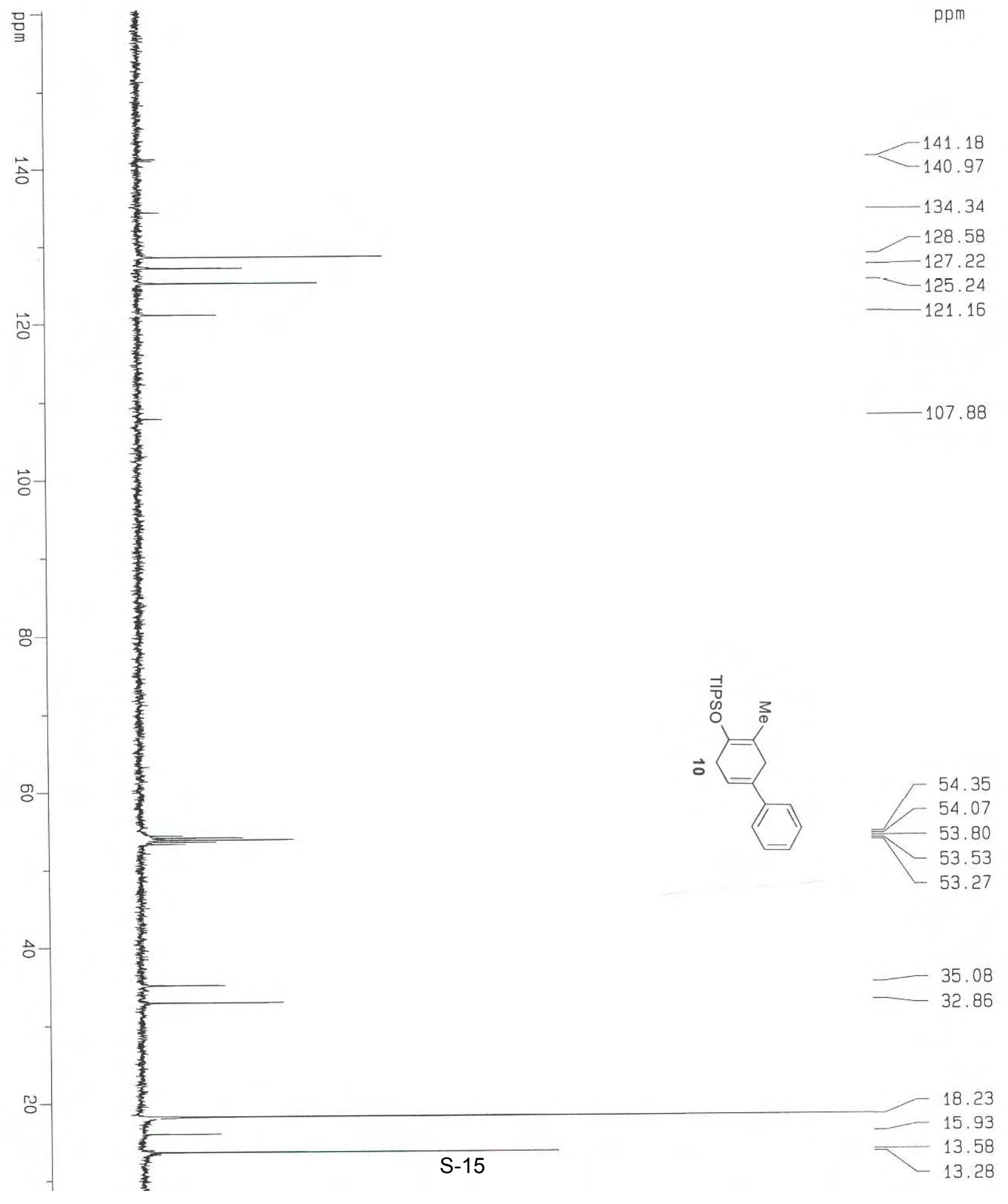




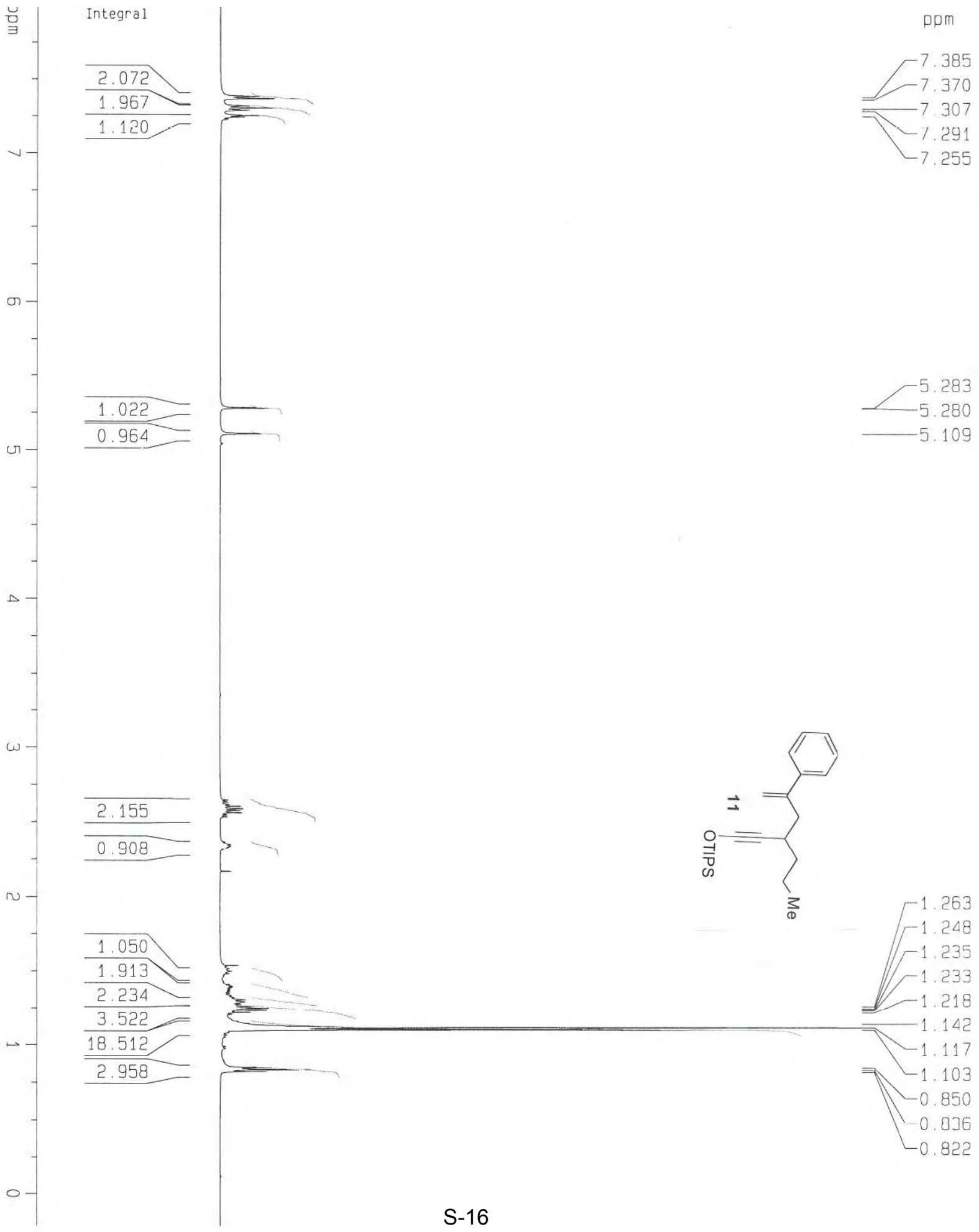




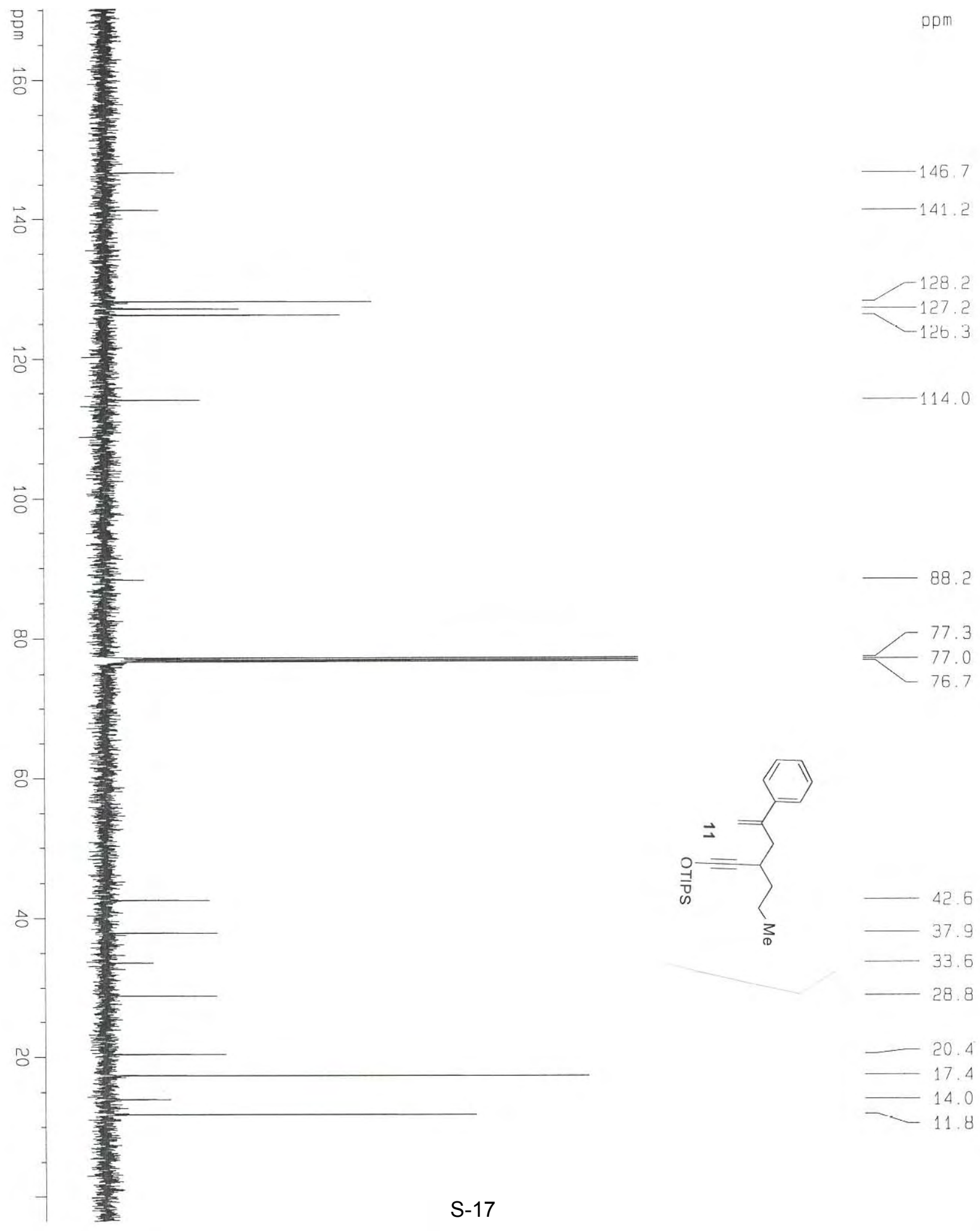




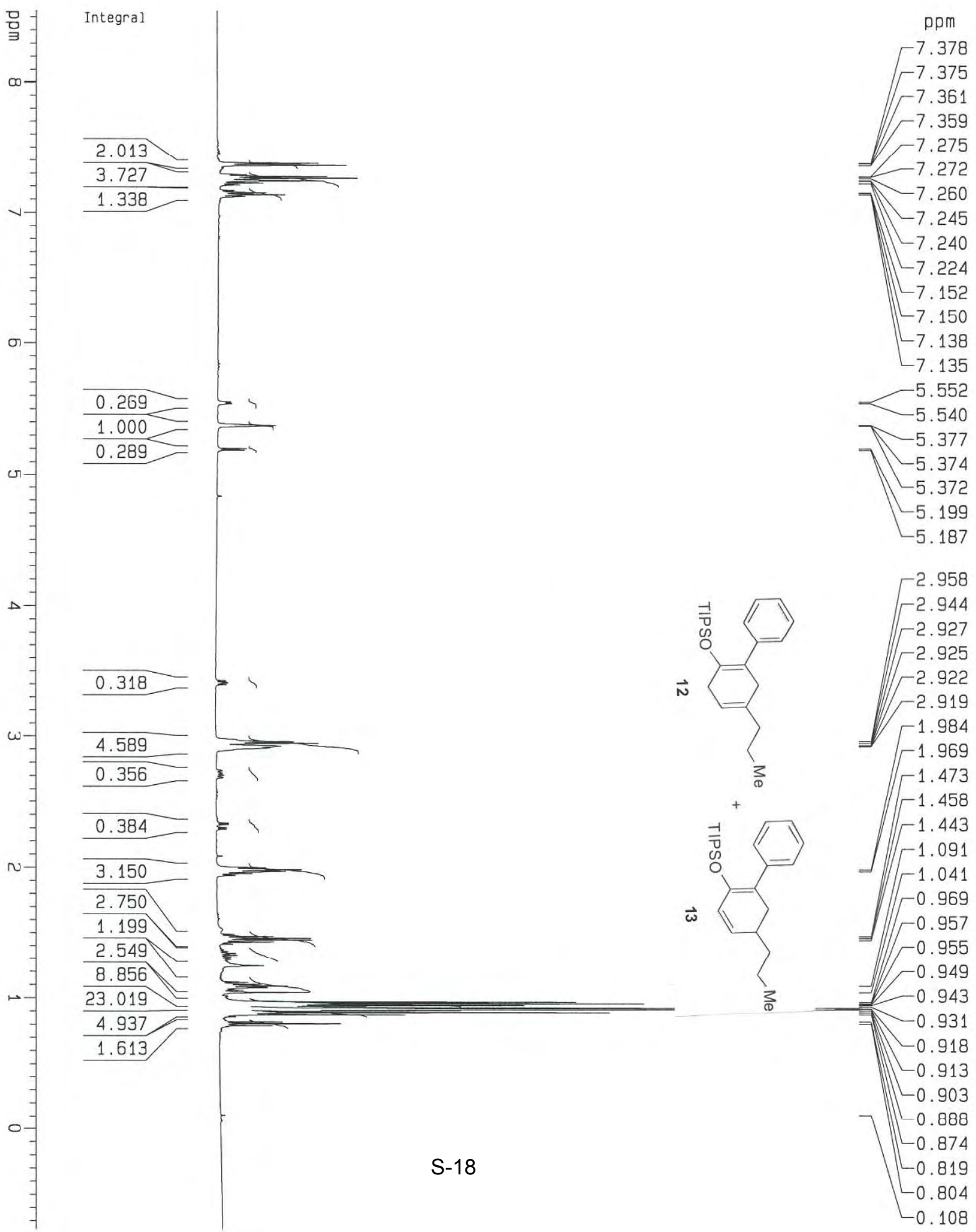




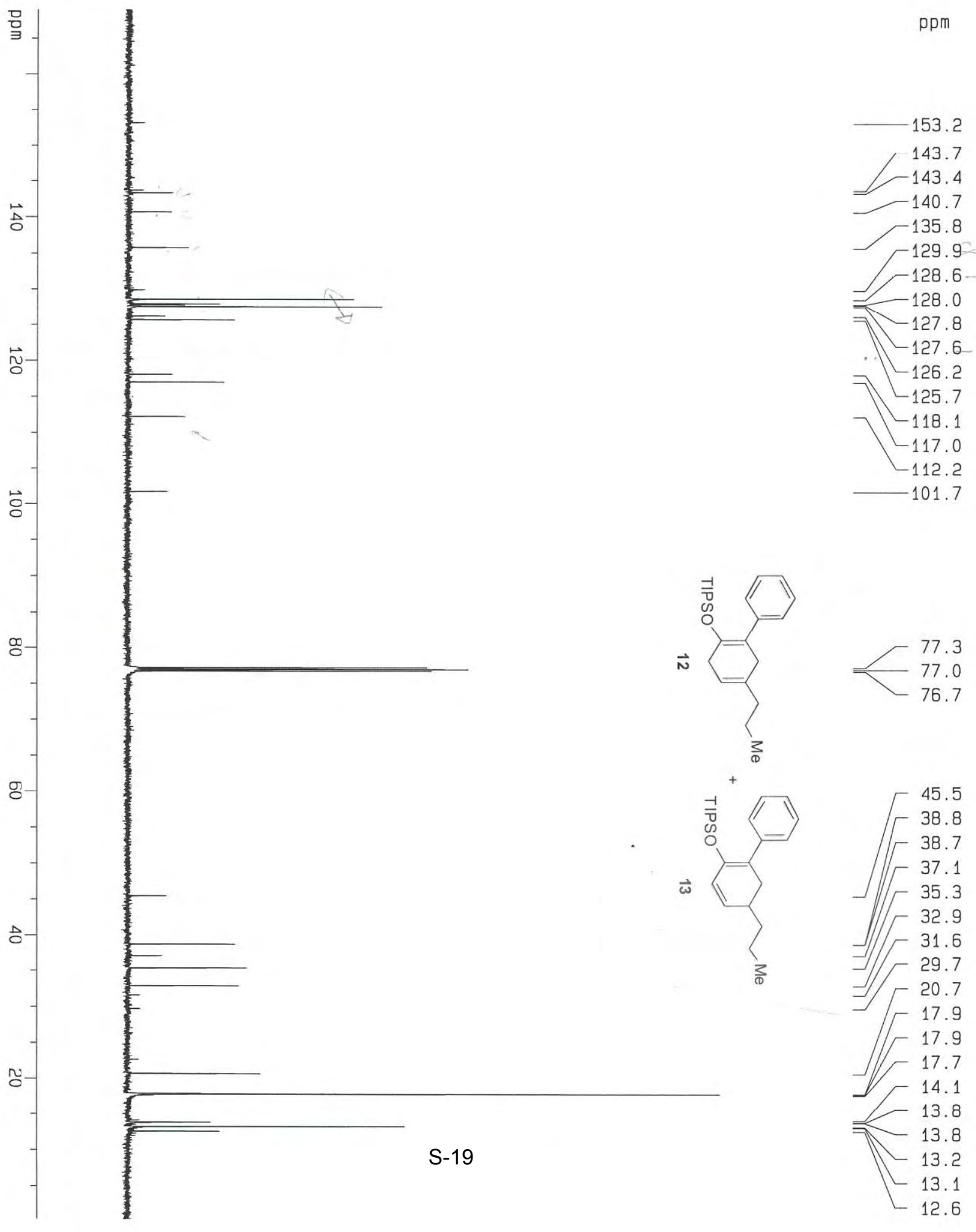




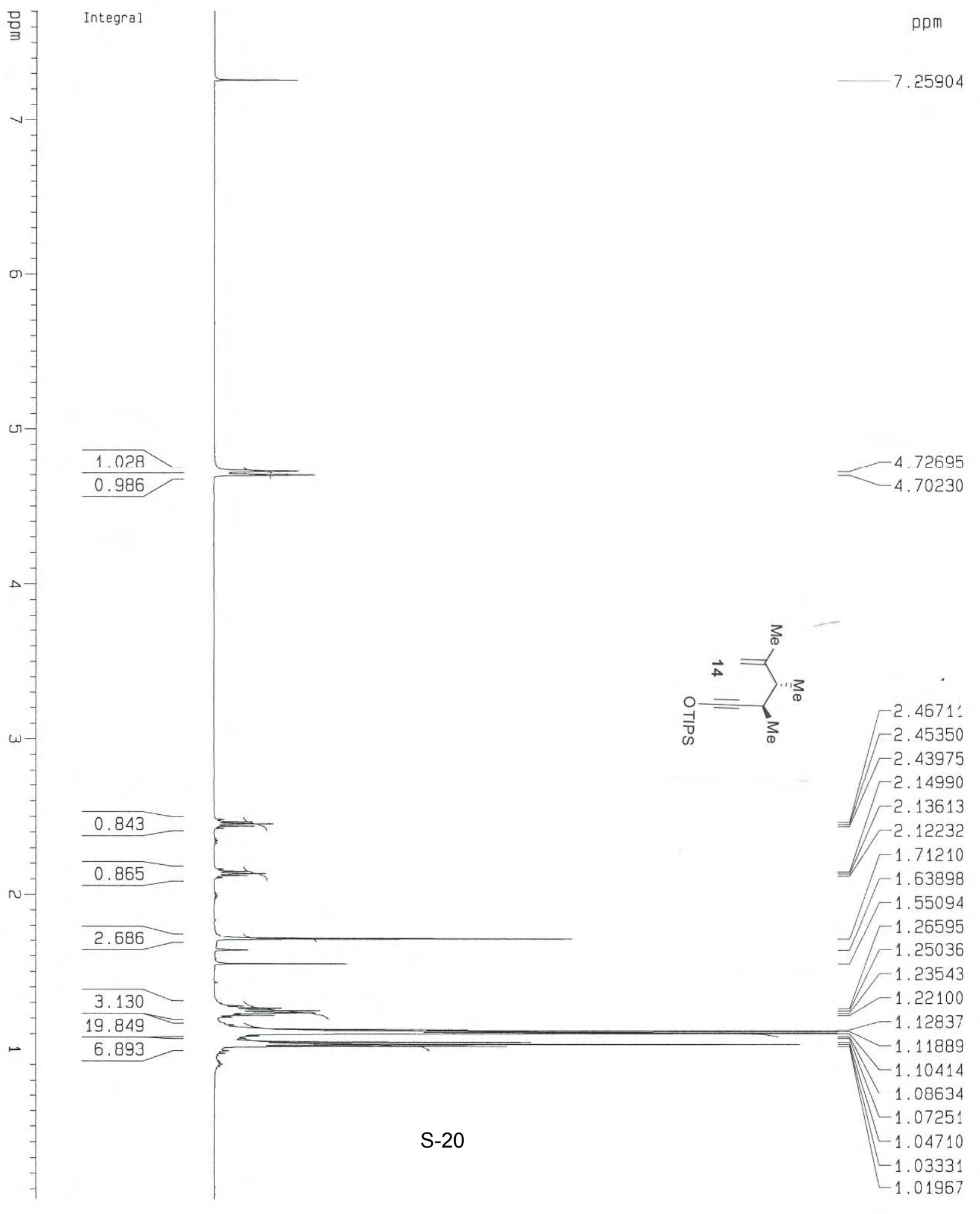



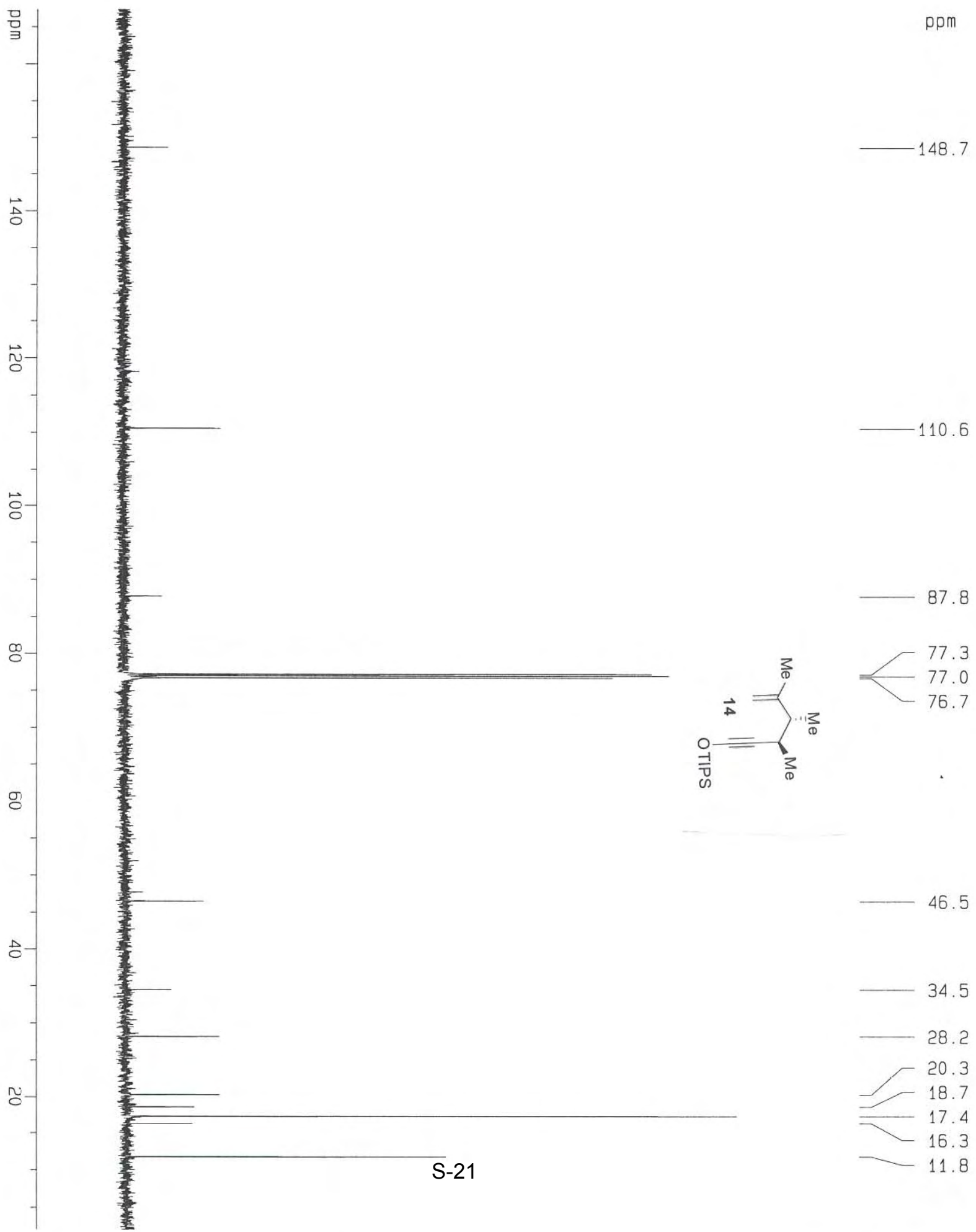

46.5

34.5

28.2

20.3

18. 7

17. 4

16. 3

11.8 


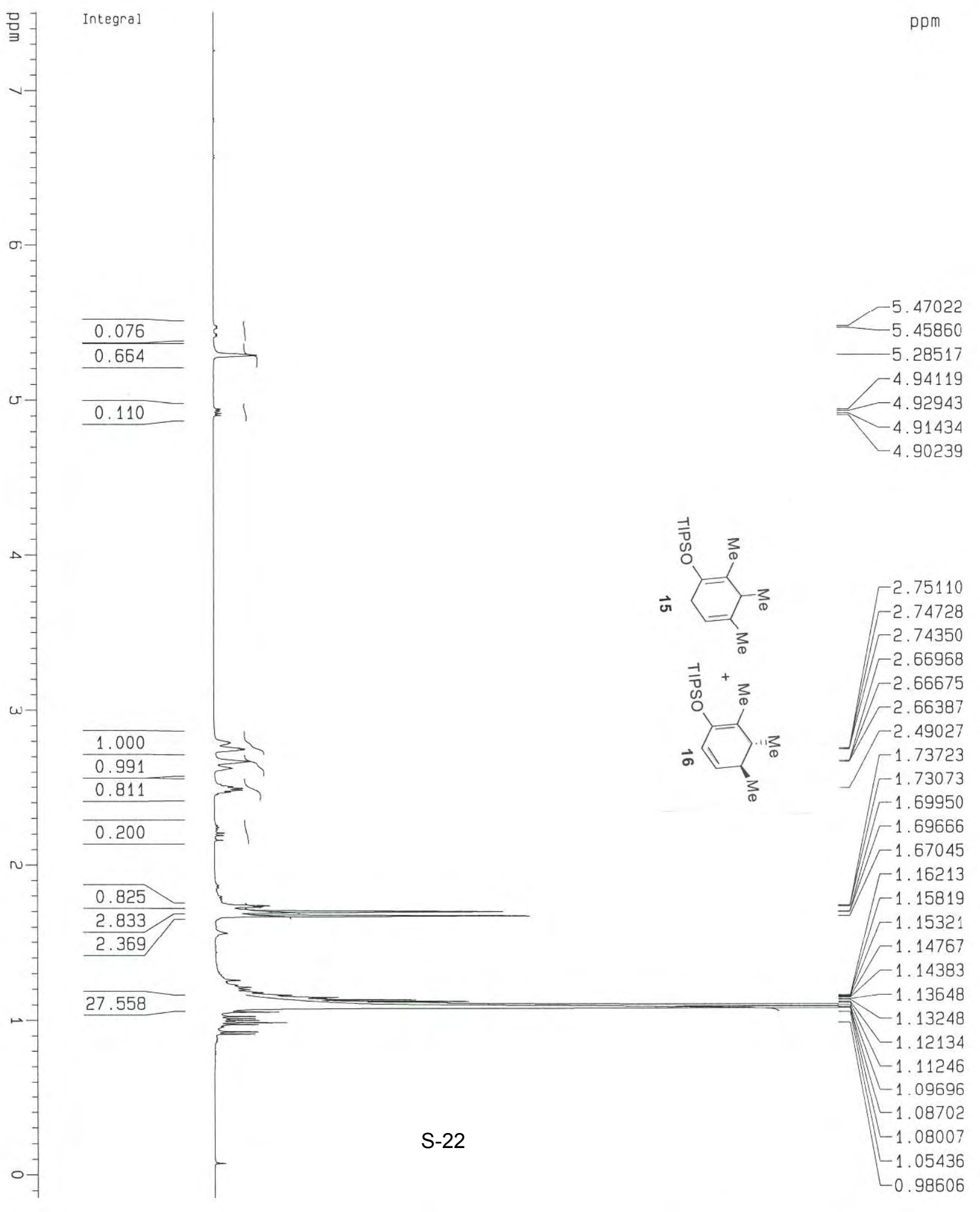




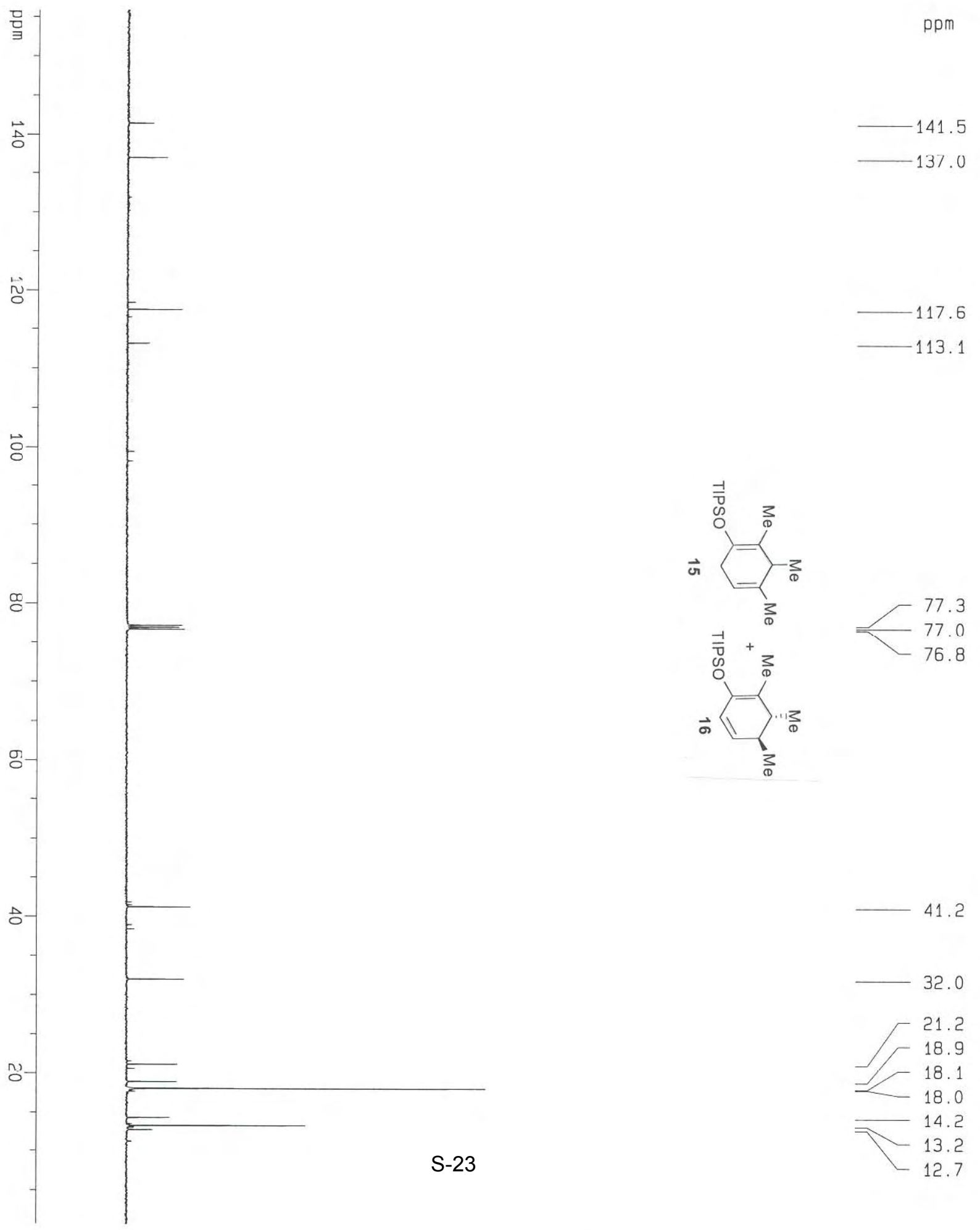




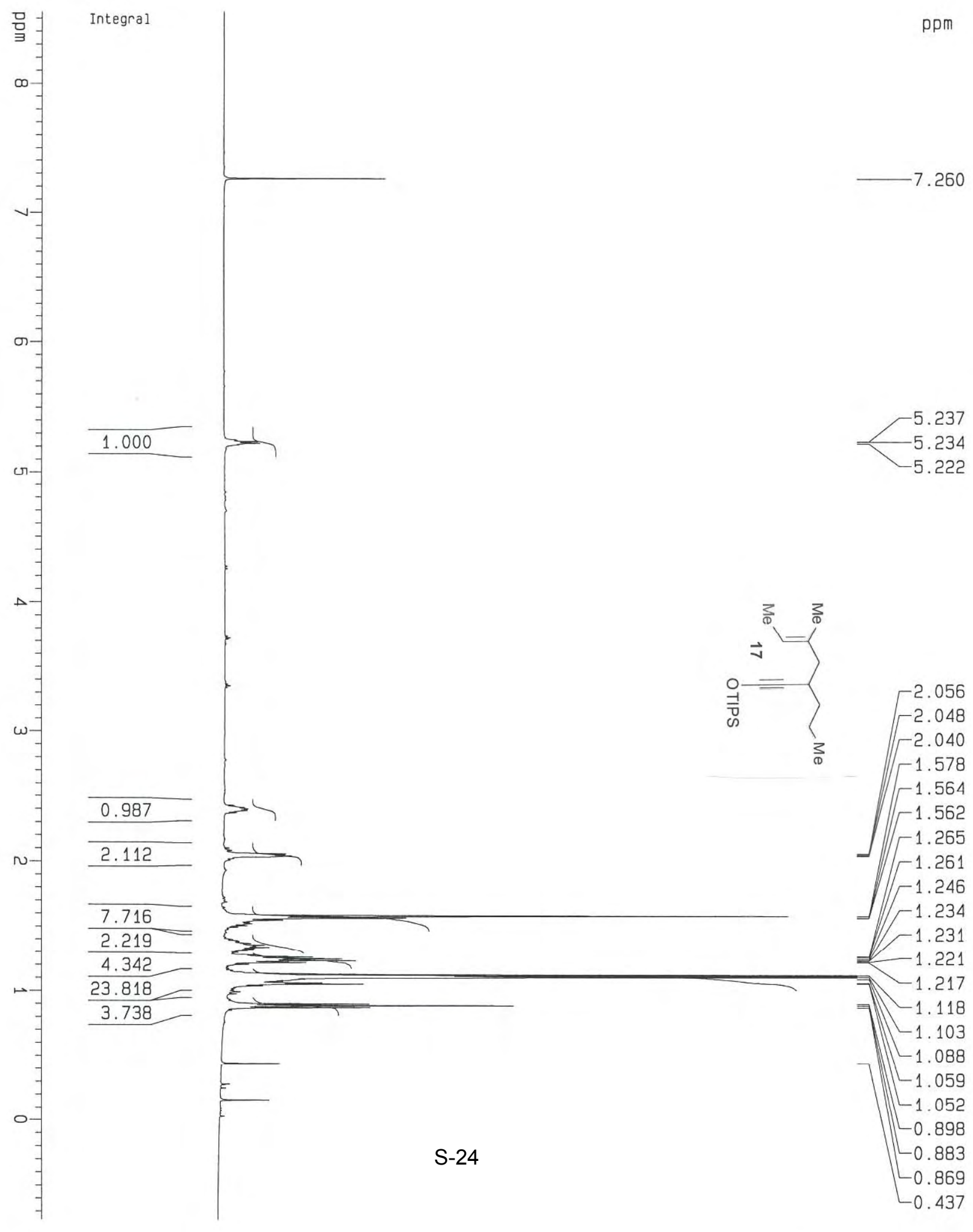




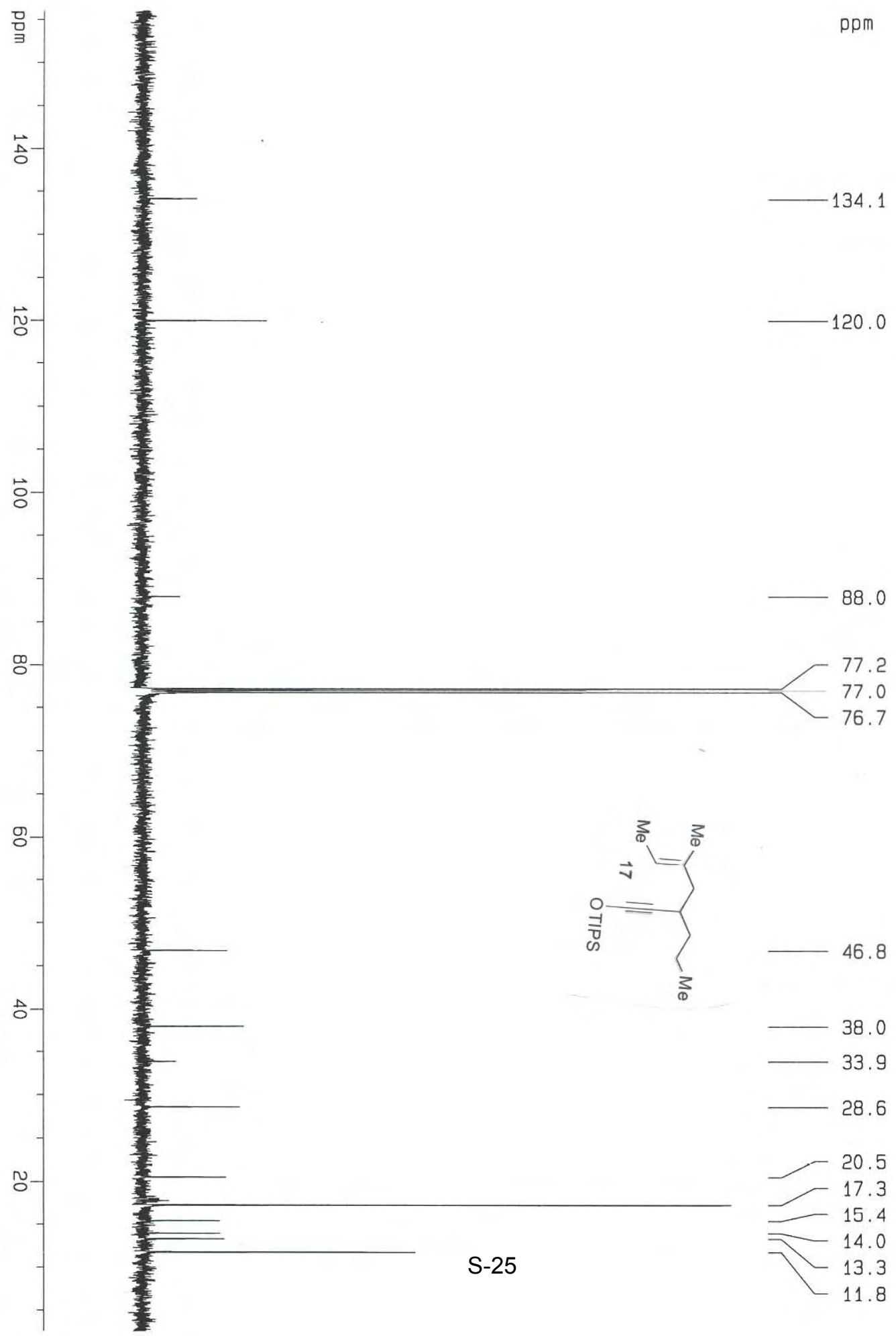




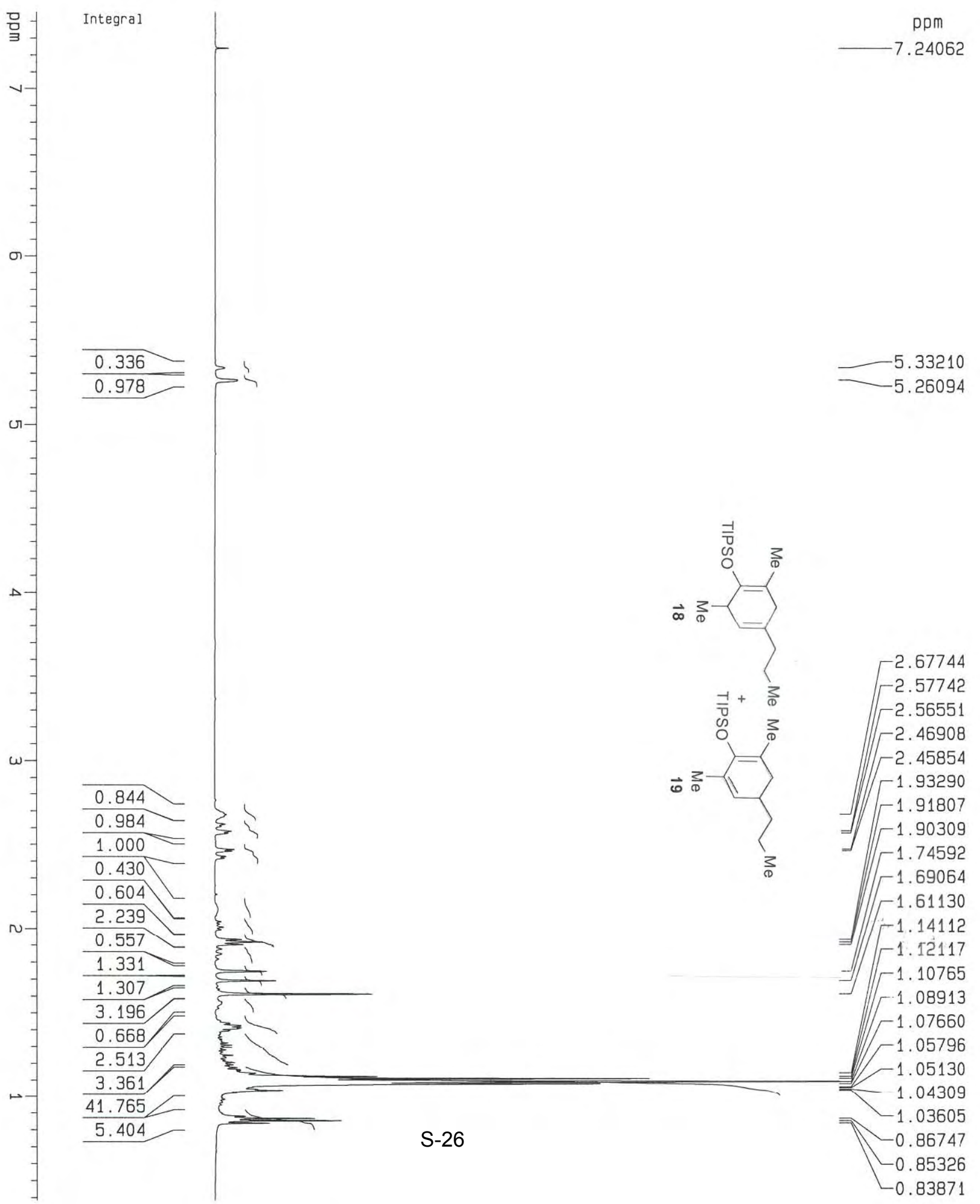



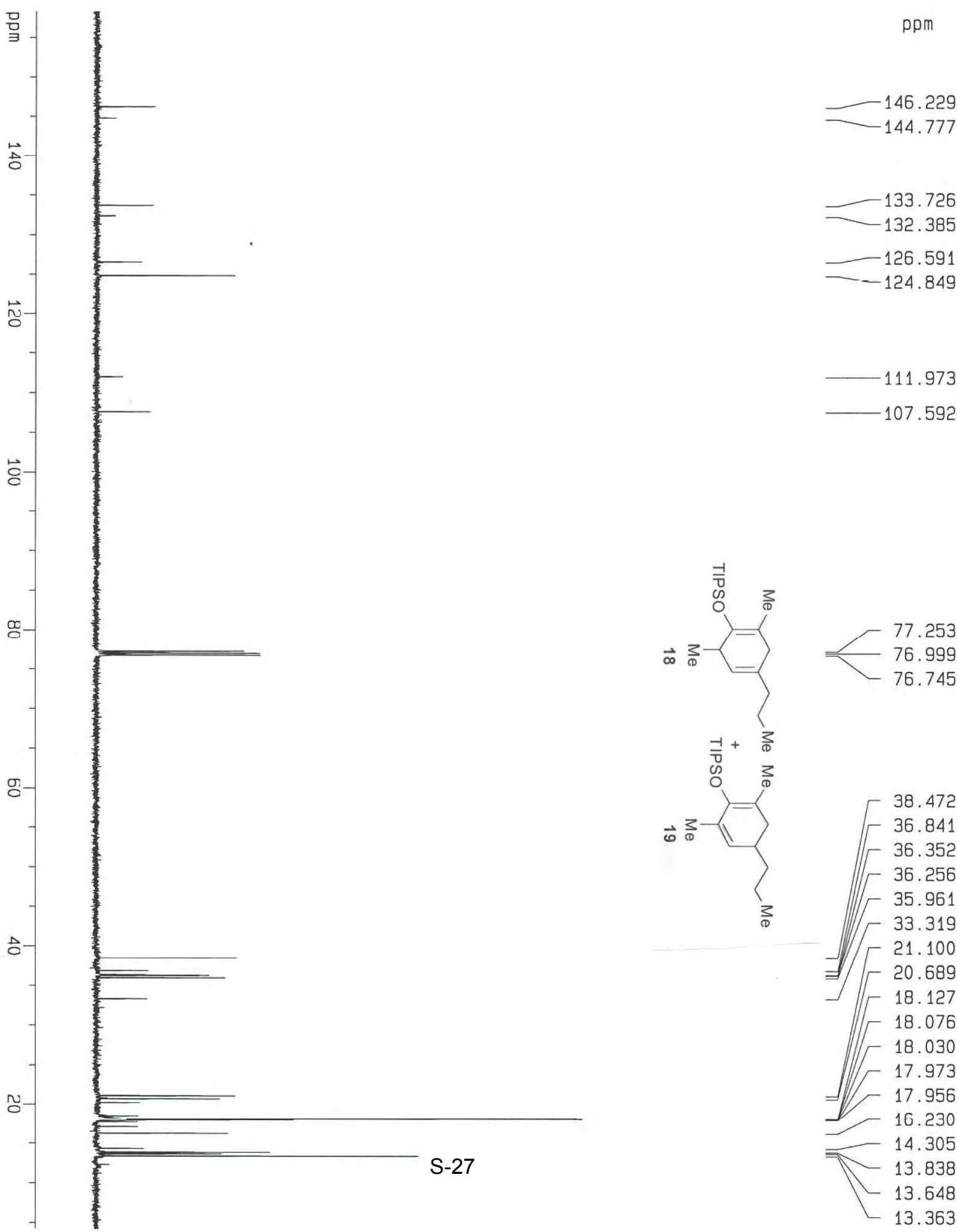
76.745

$-38.472$ - 36.841 $-36.352$ 


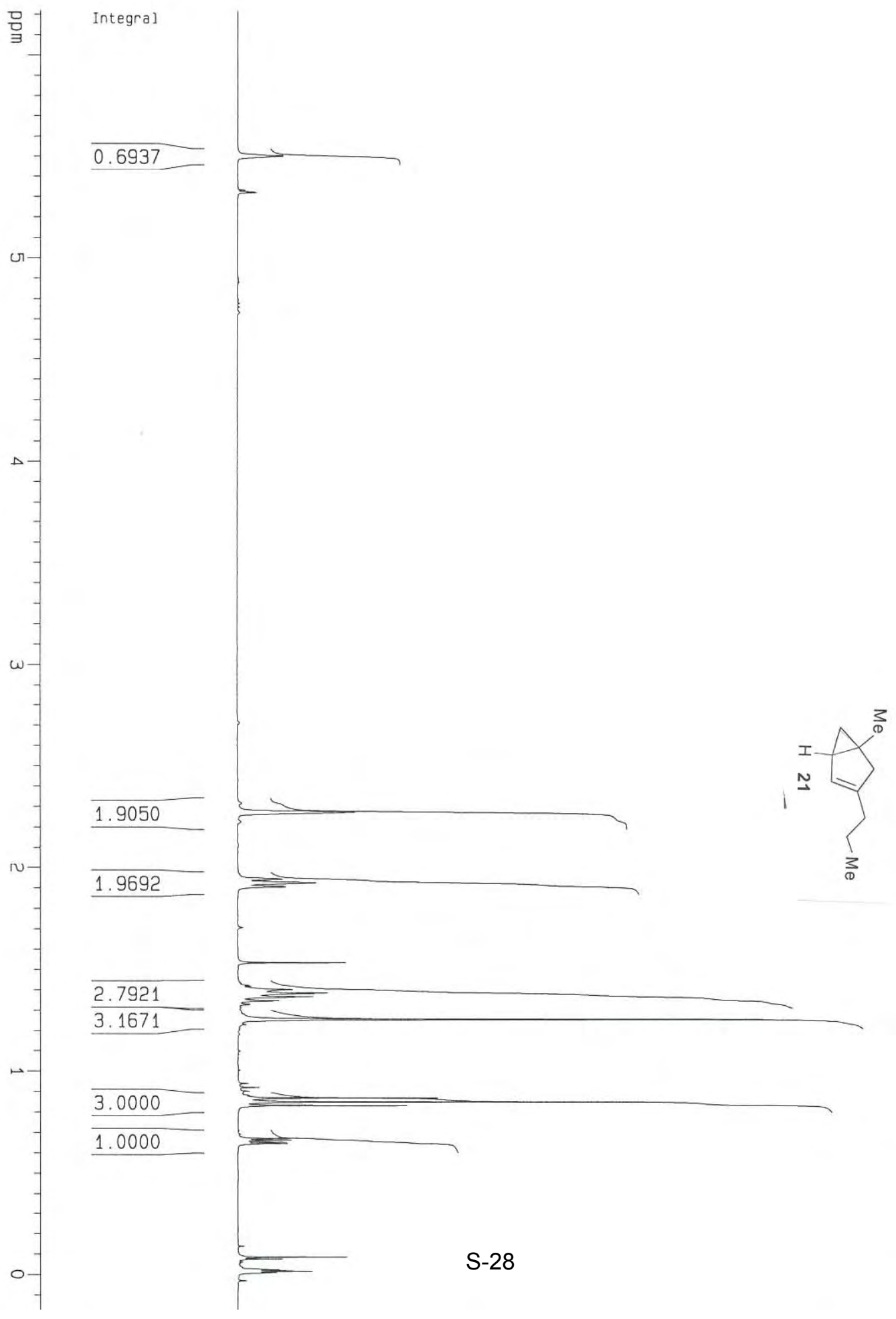




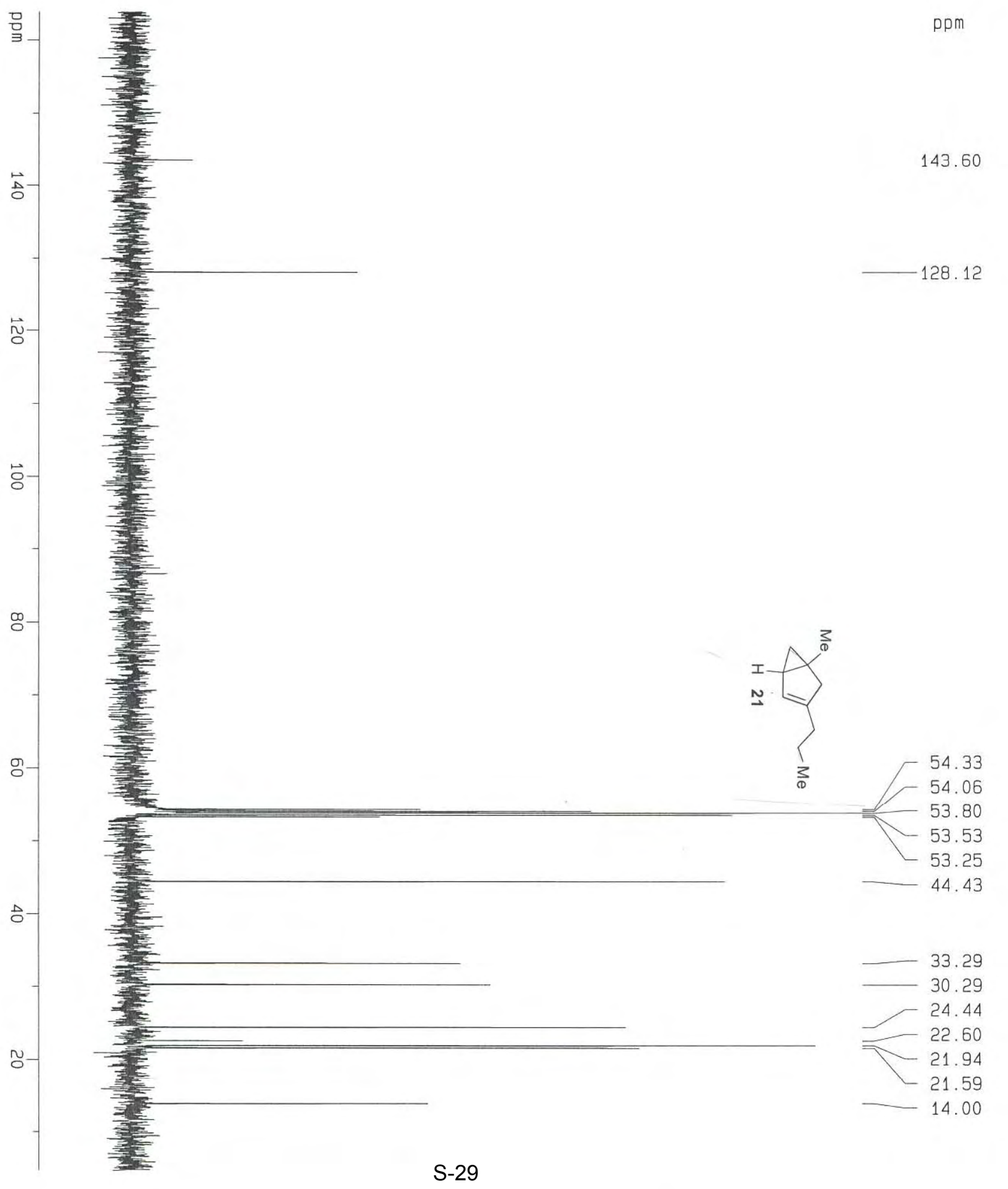




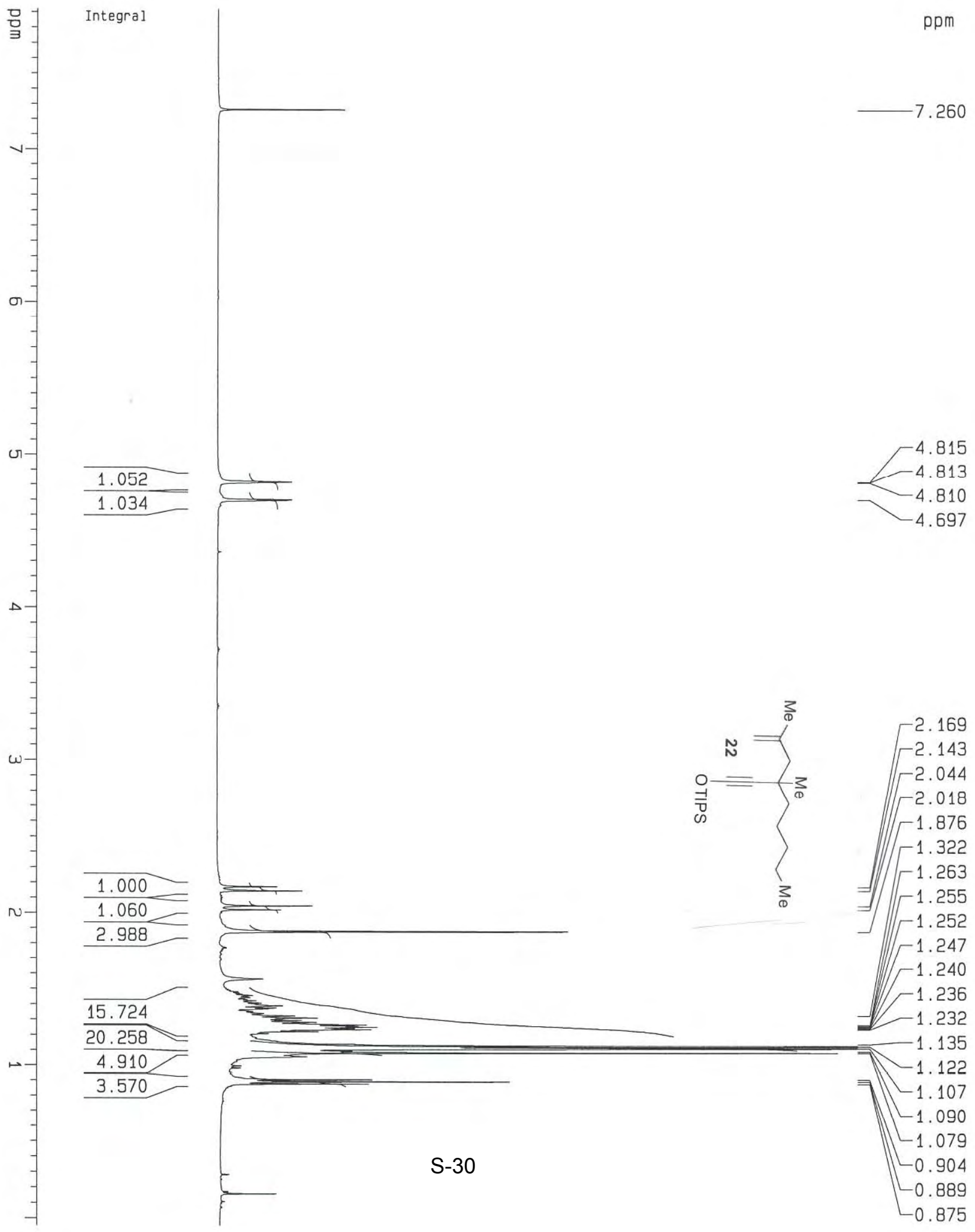



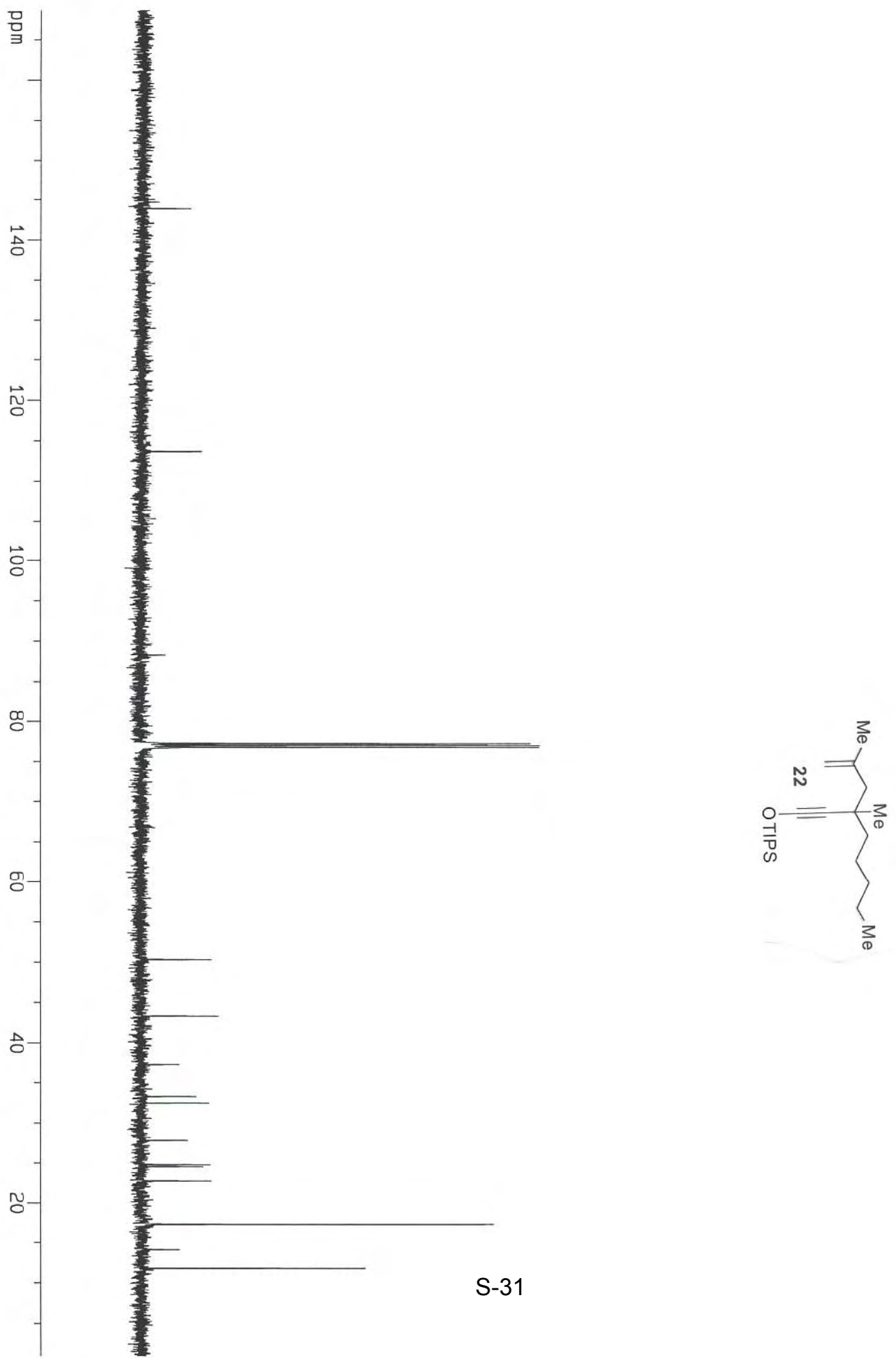

50.3

43.3

37.3

33.3 32.5

27.9 24.8 24.5 22. 8 17.4 14. 1 11.8 


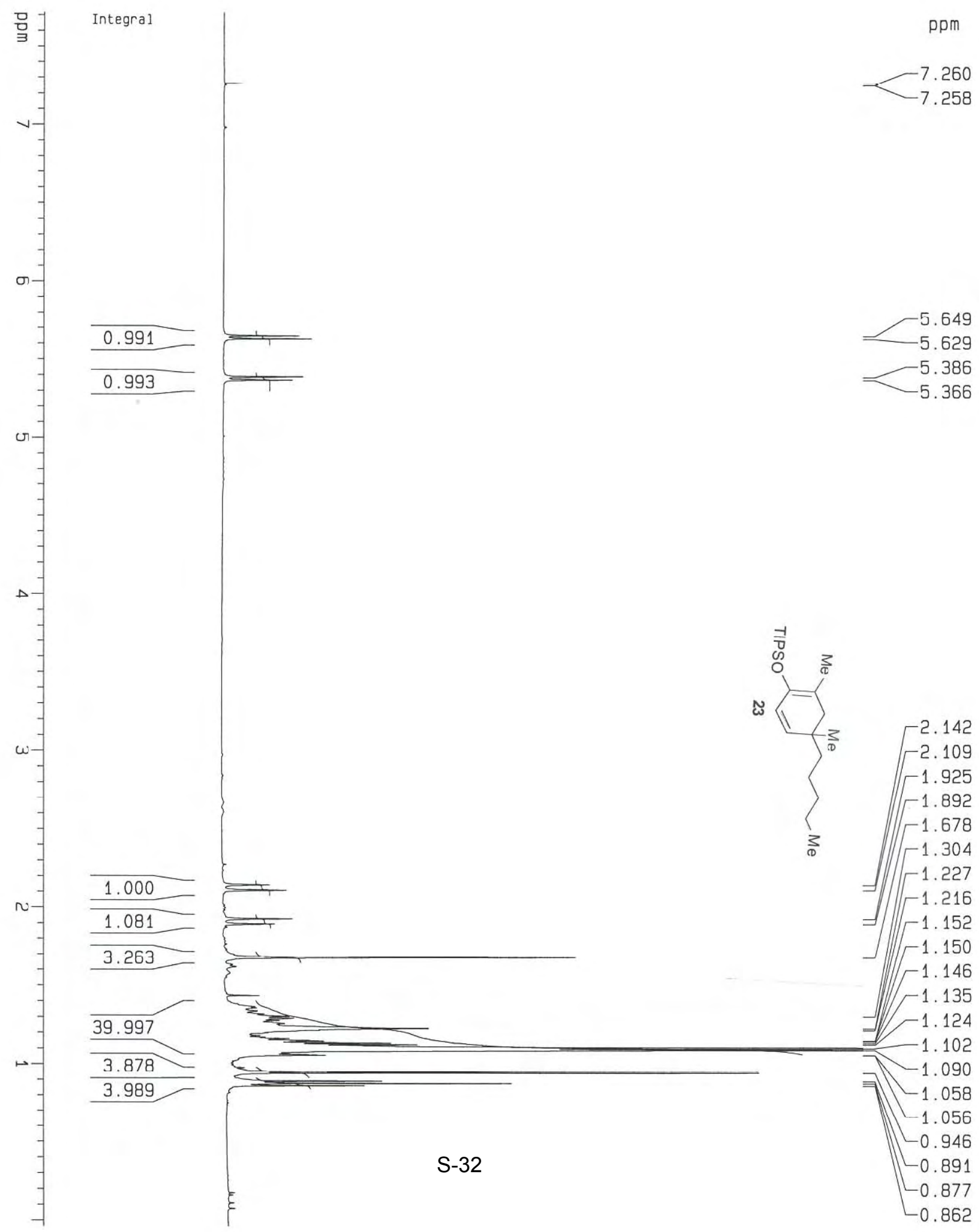




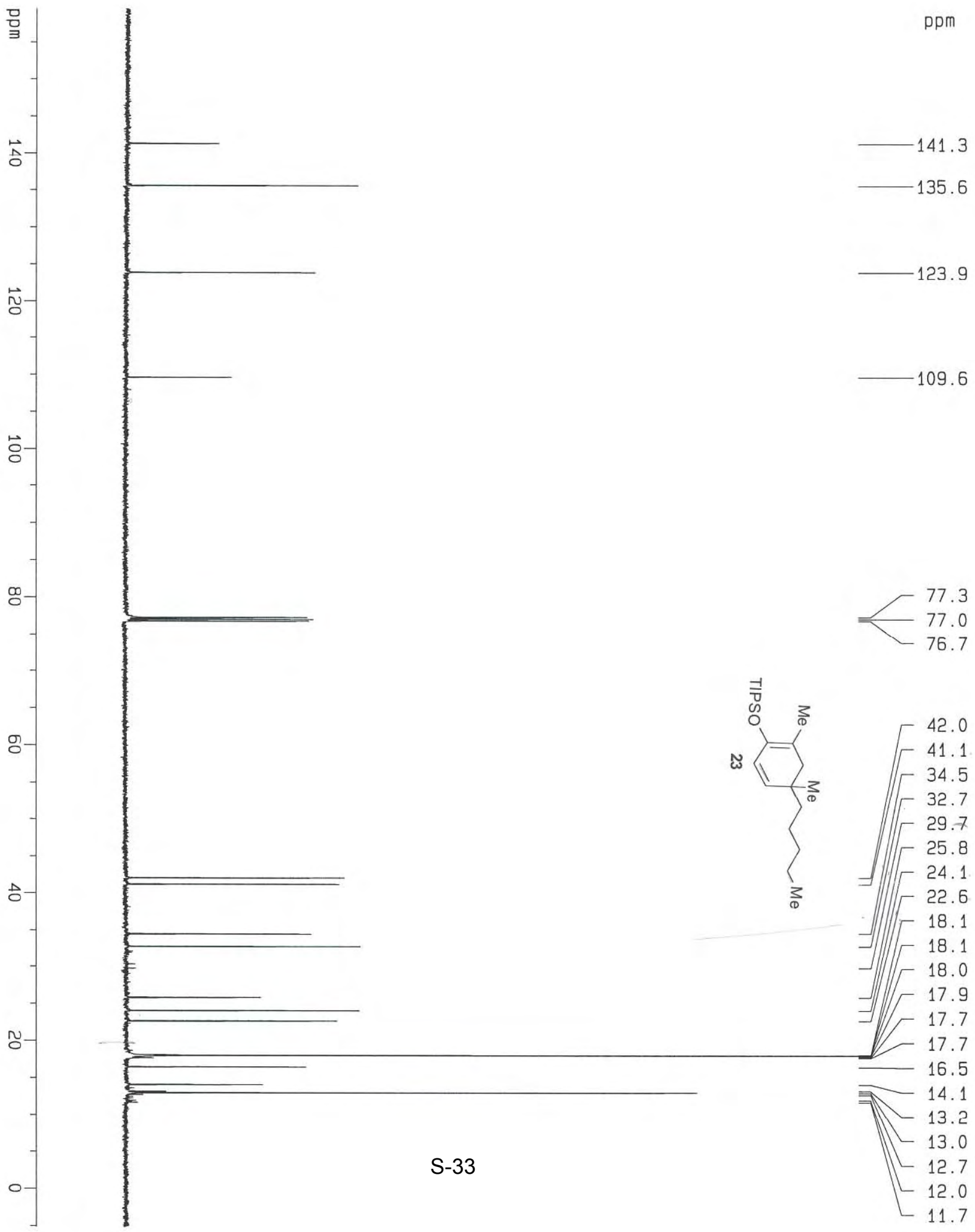




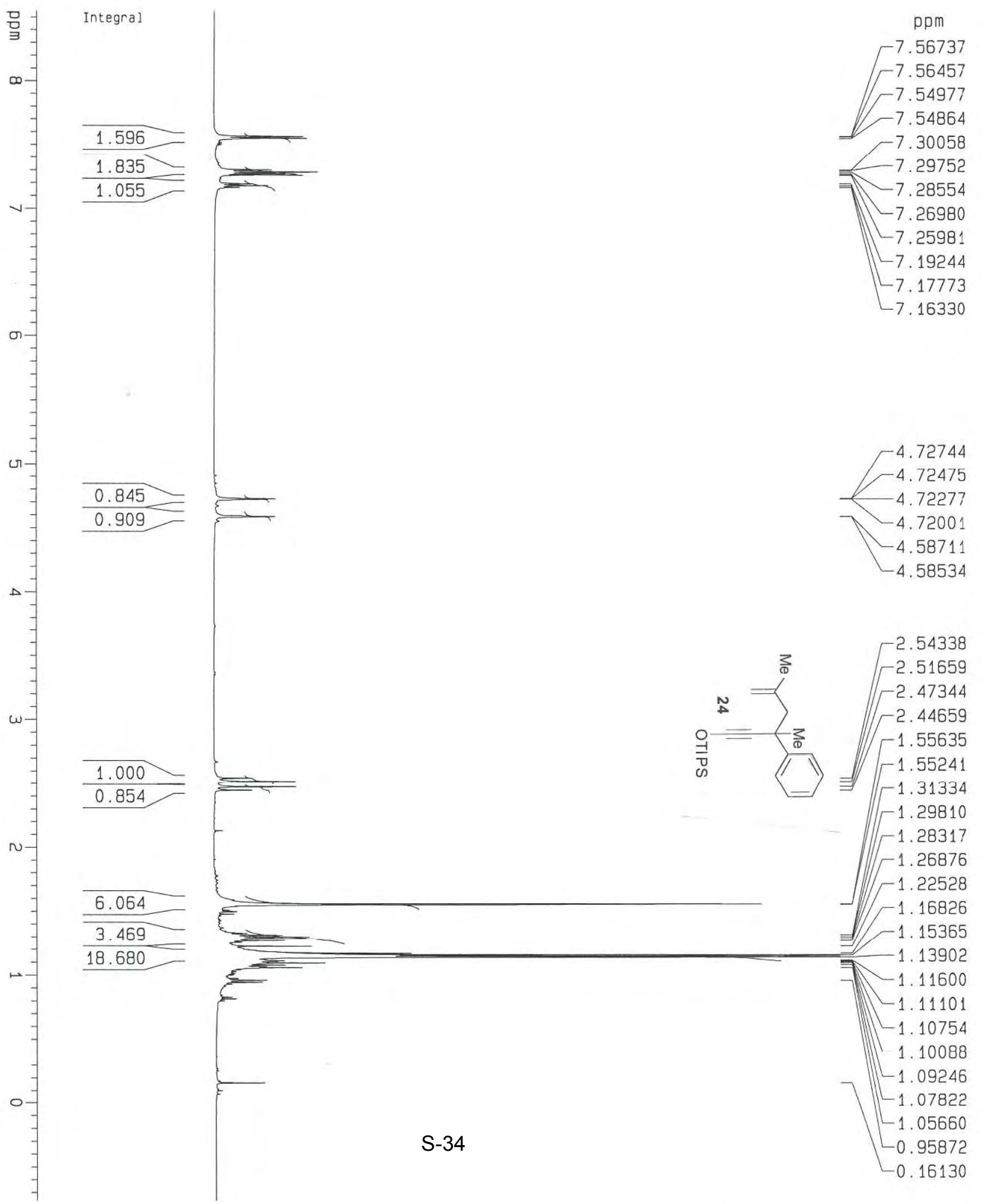




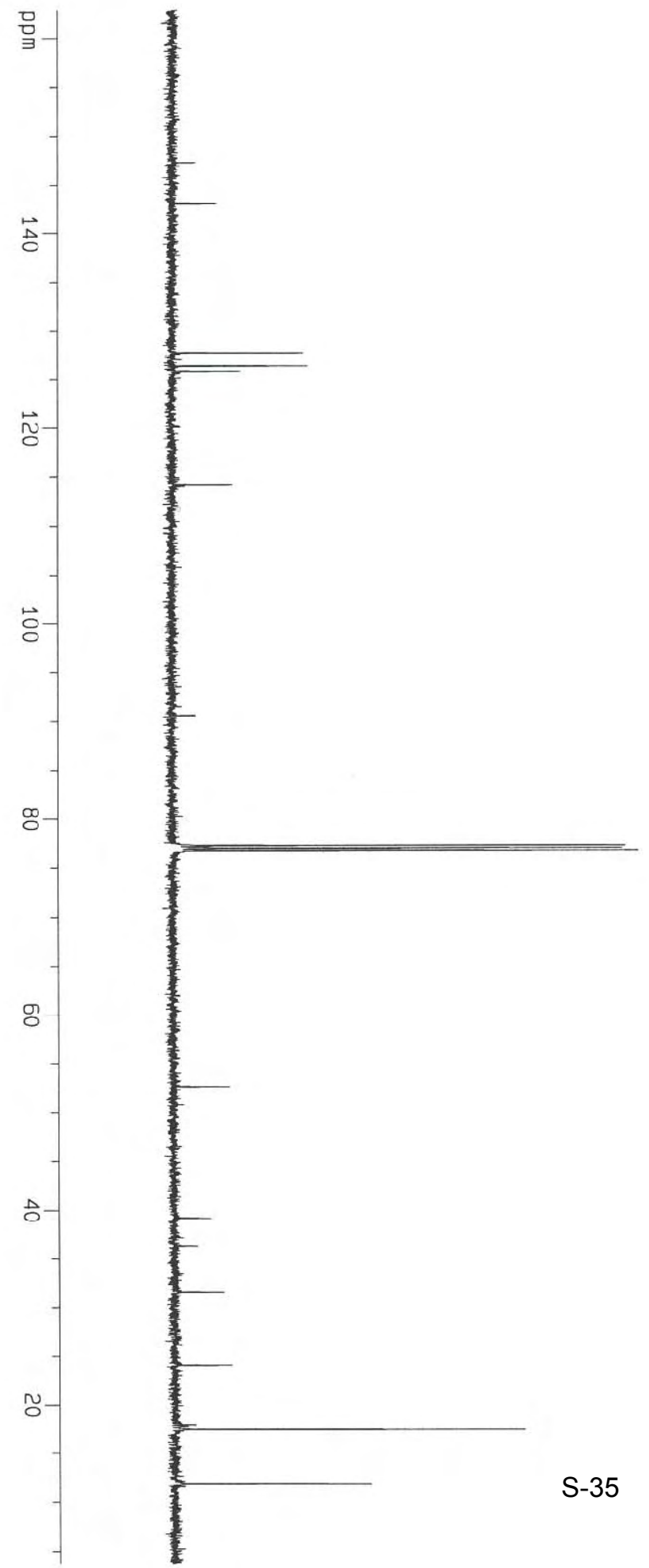

$-127.7$ 126.4 125.8
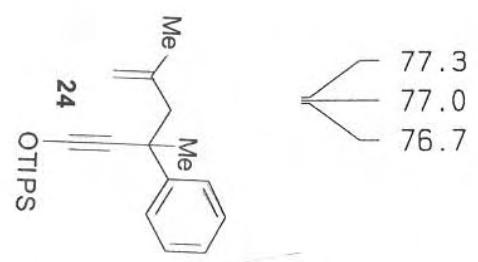

52.6

39.2

36.3

31.6

24.1

17.4

11.9 


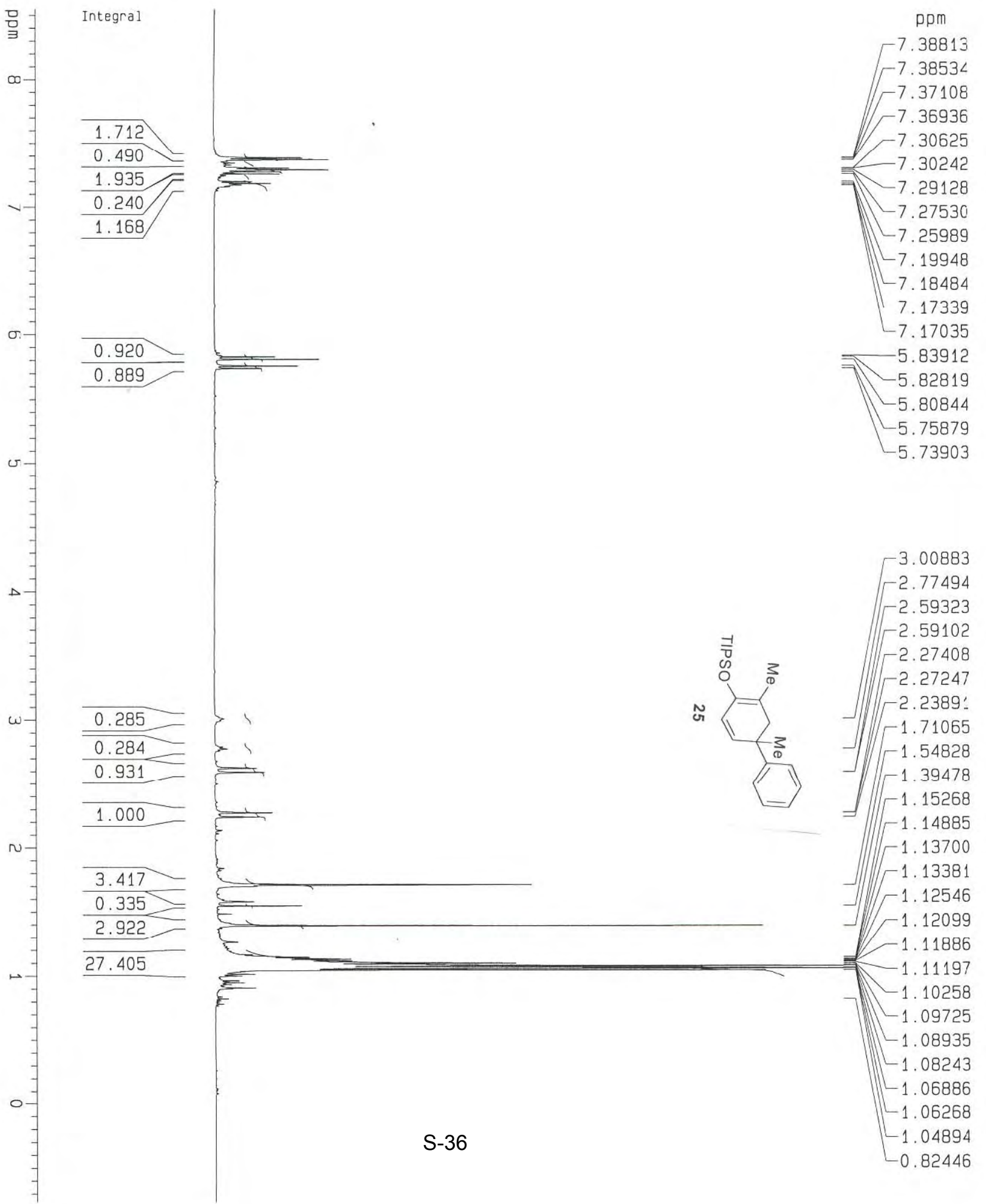




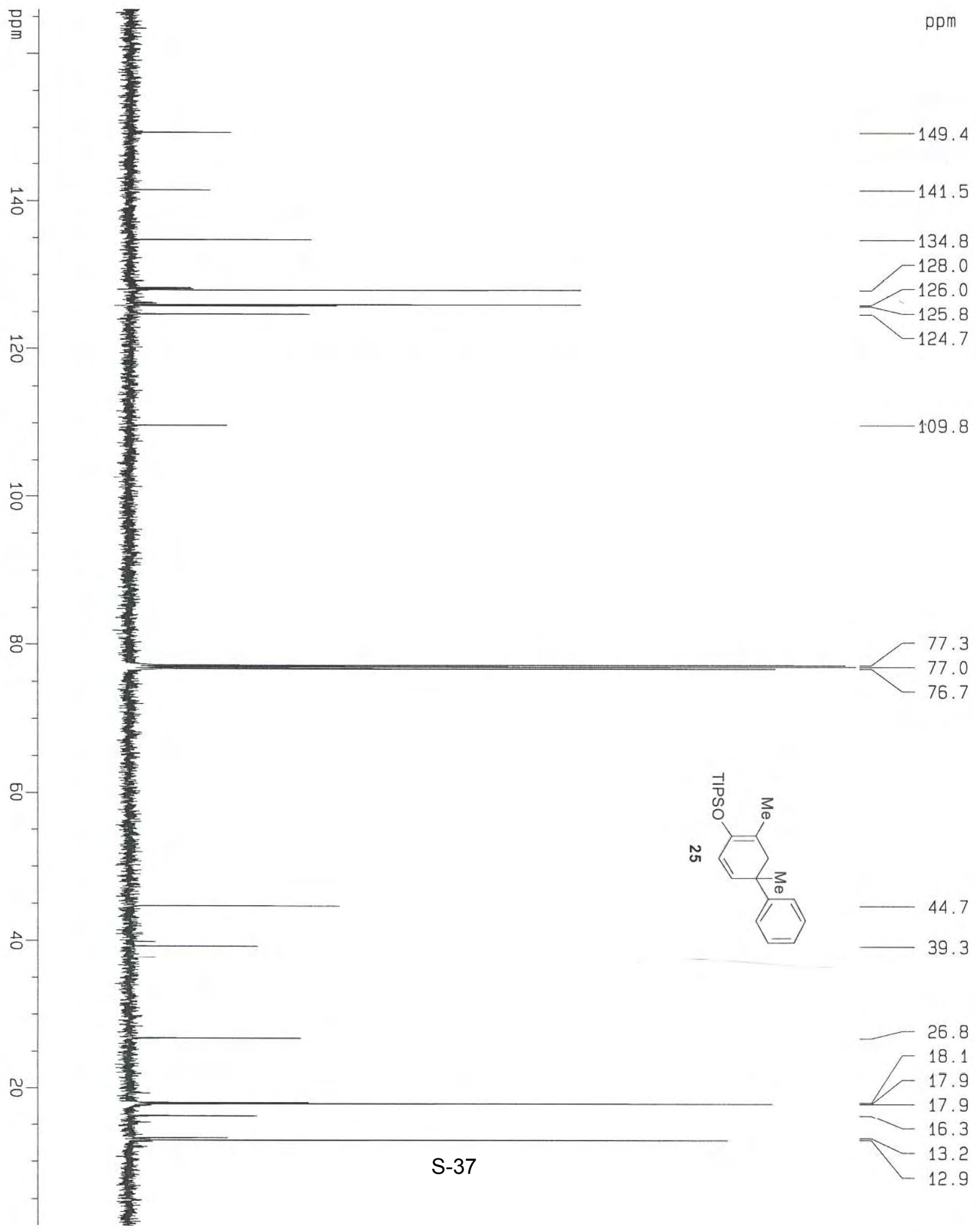




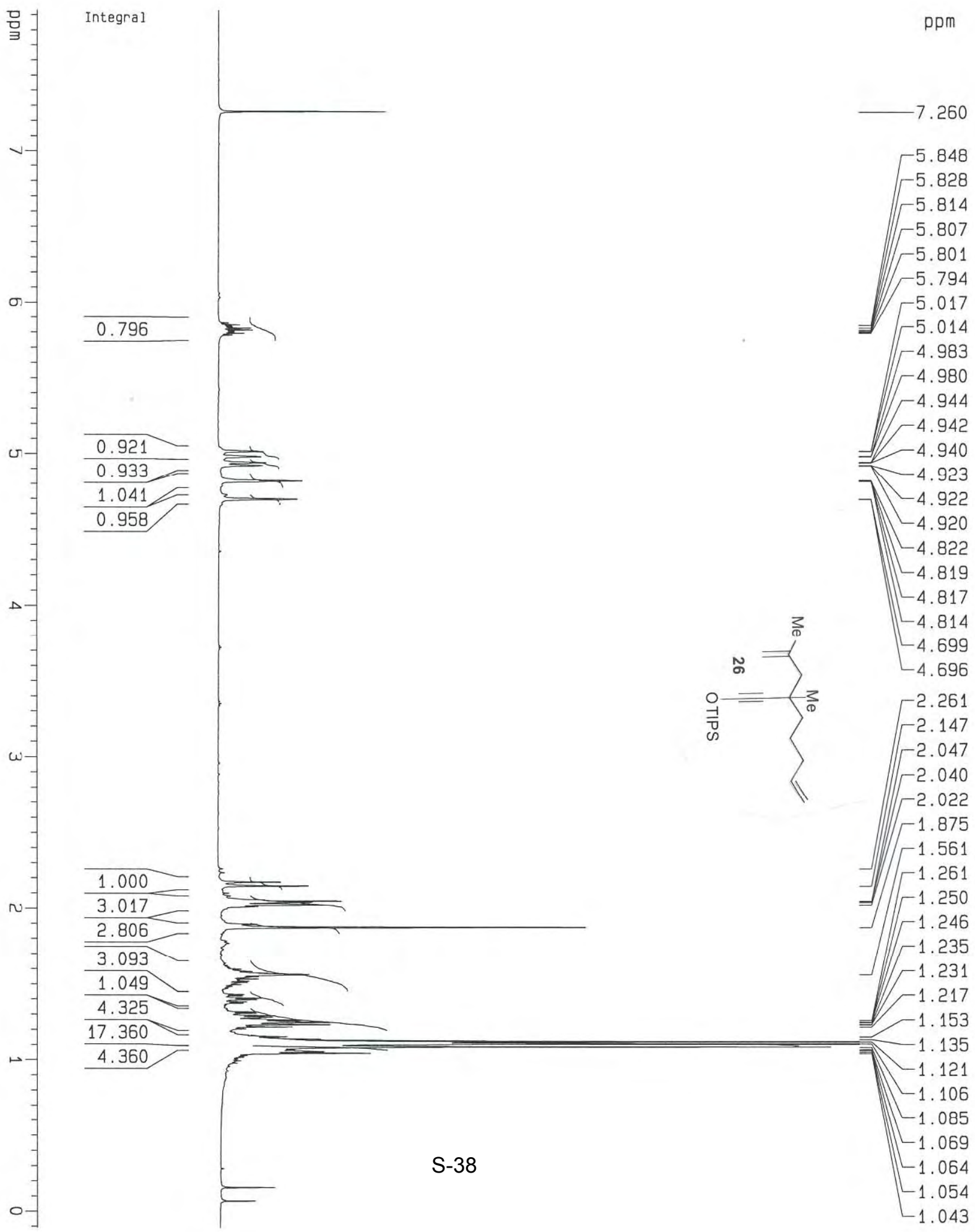



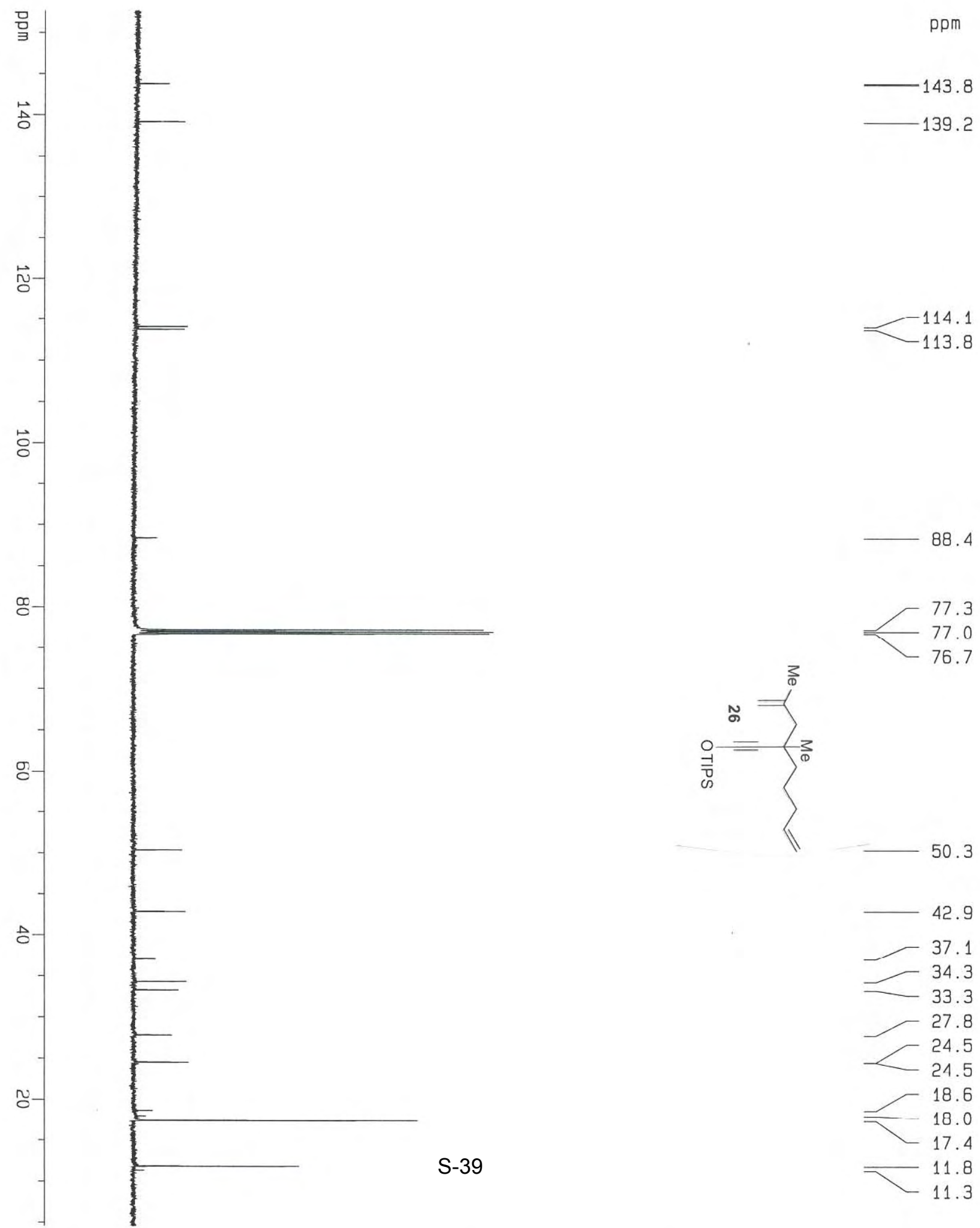

50.3

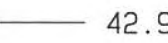

$-37.1$ 34.3 33.3 27.8 24.5 24.5 18.6 18.0 17.4 11.8 11.3 


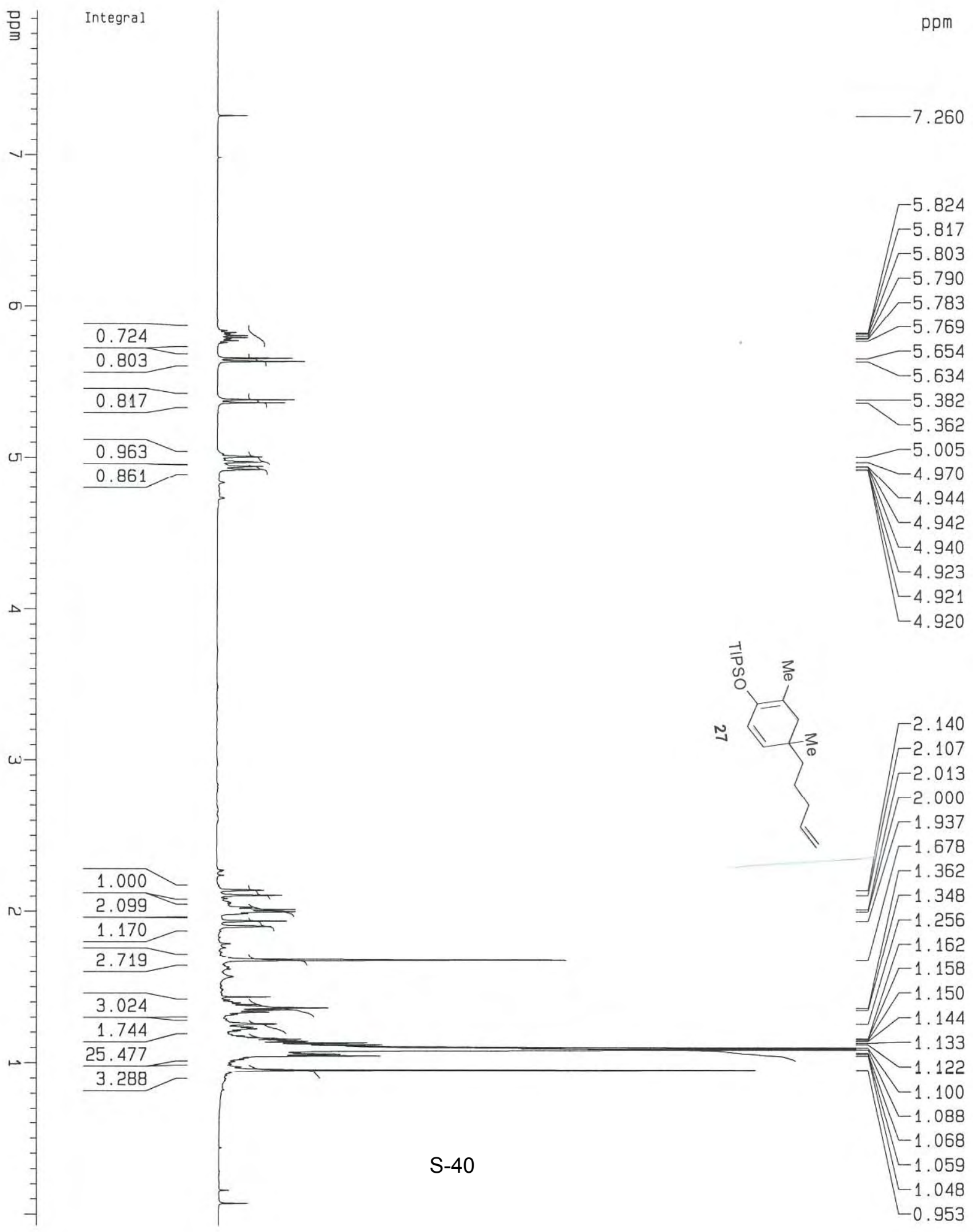




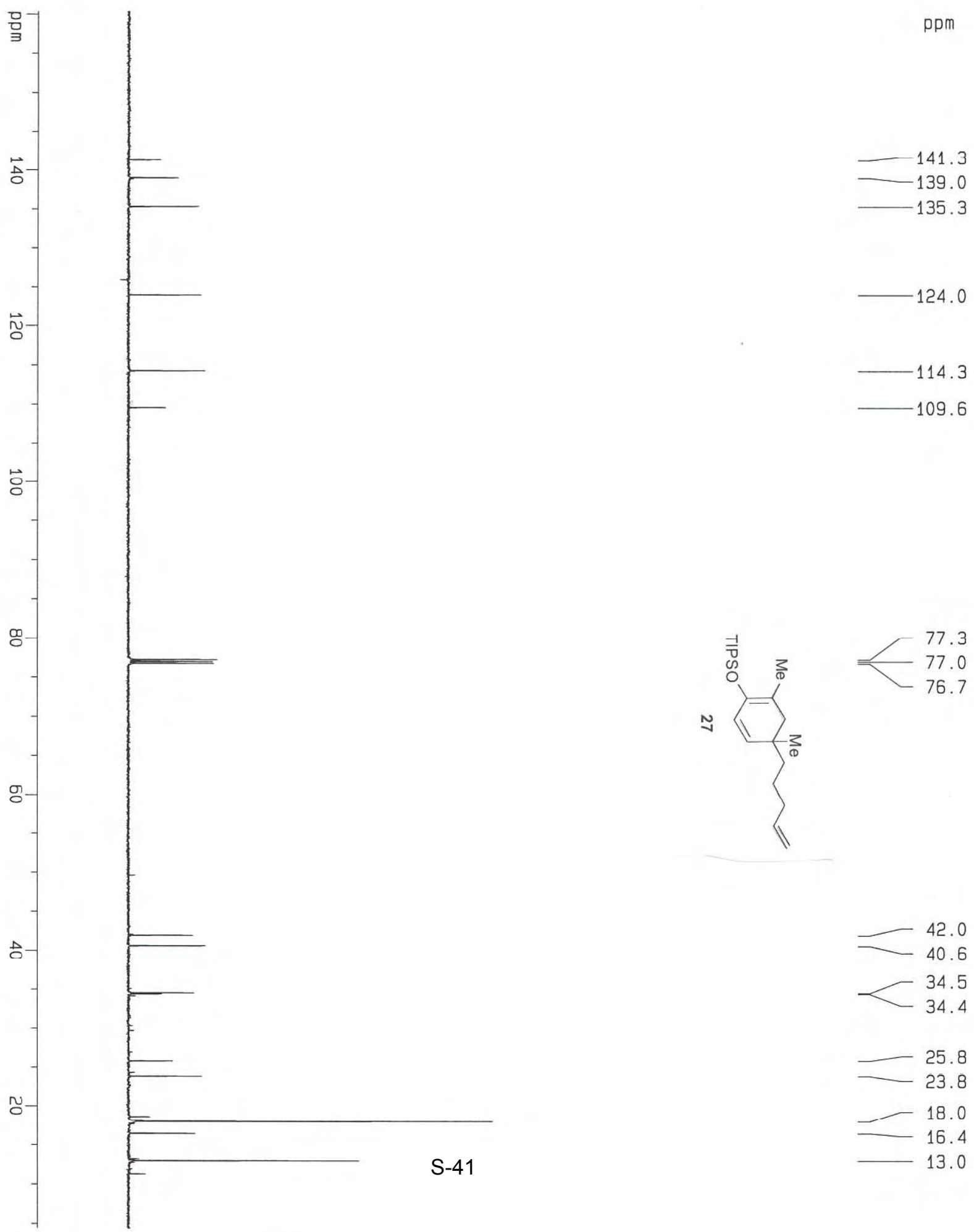




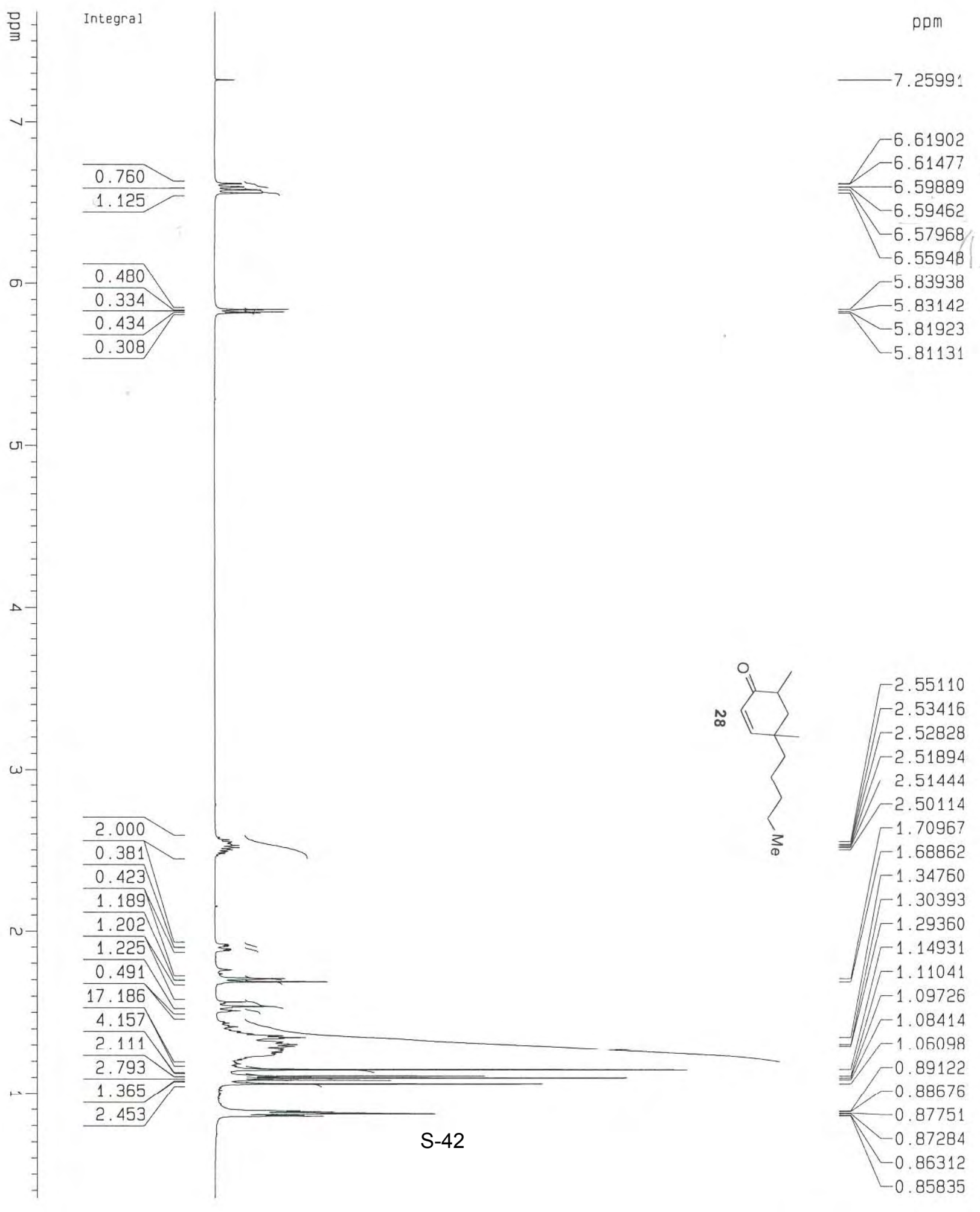



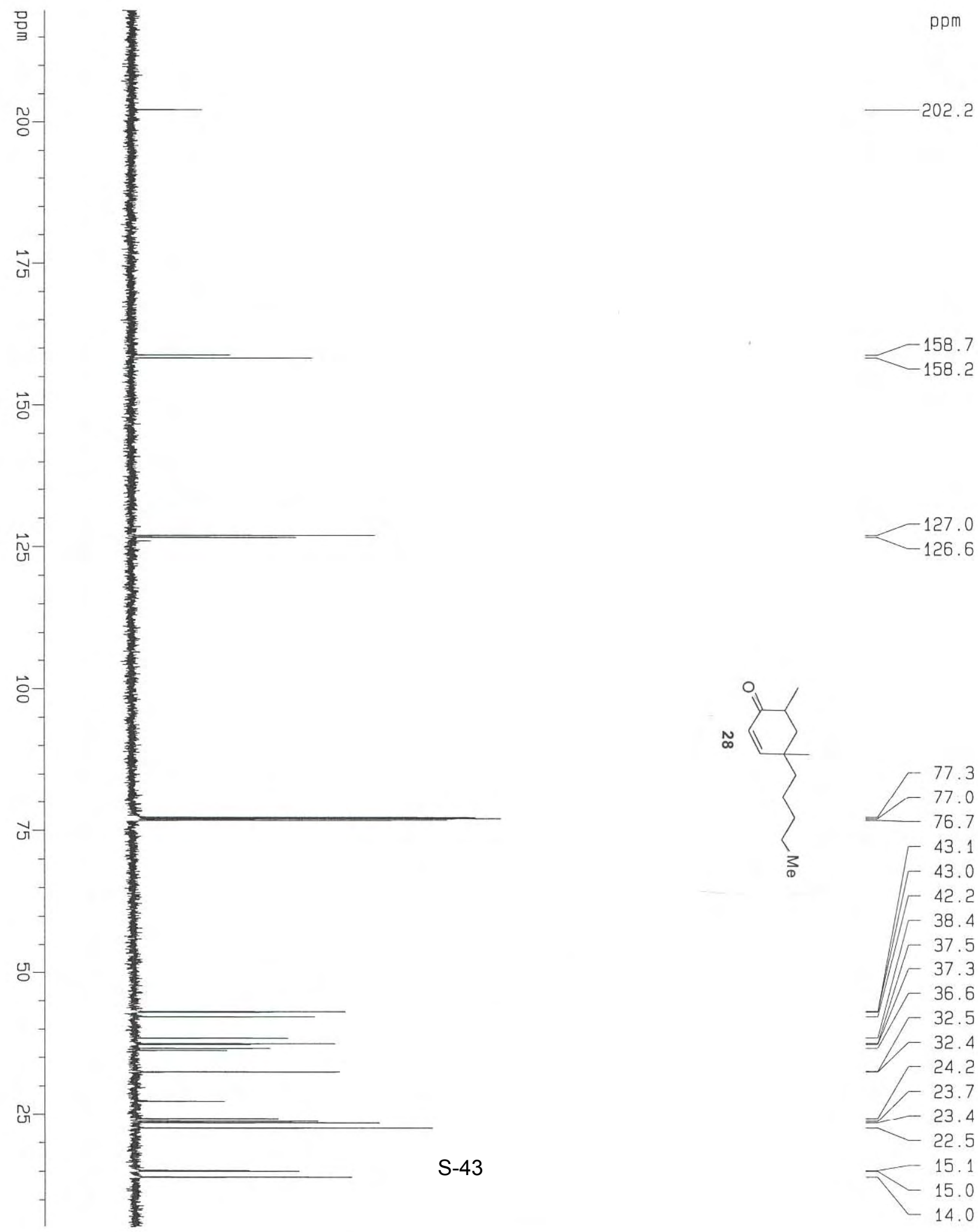


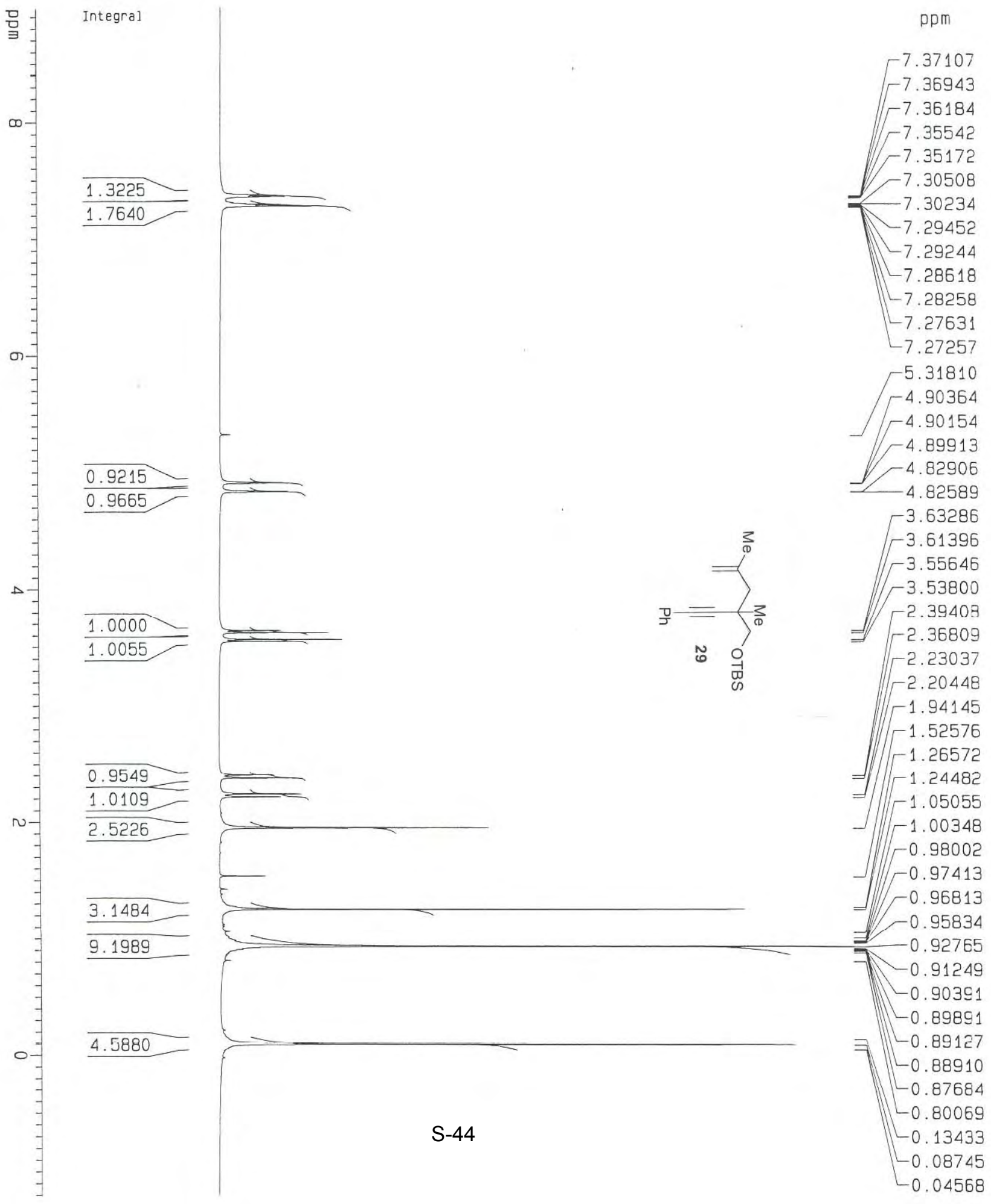




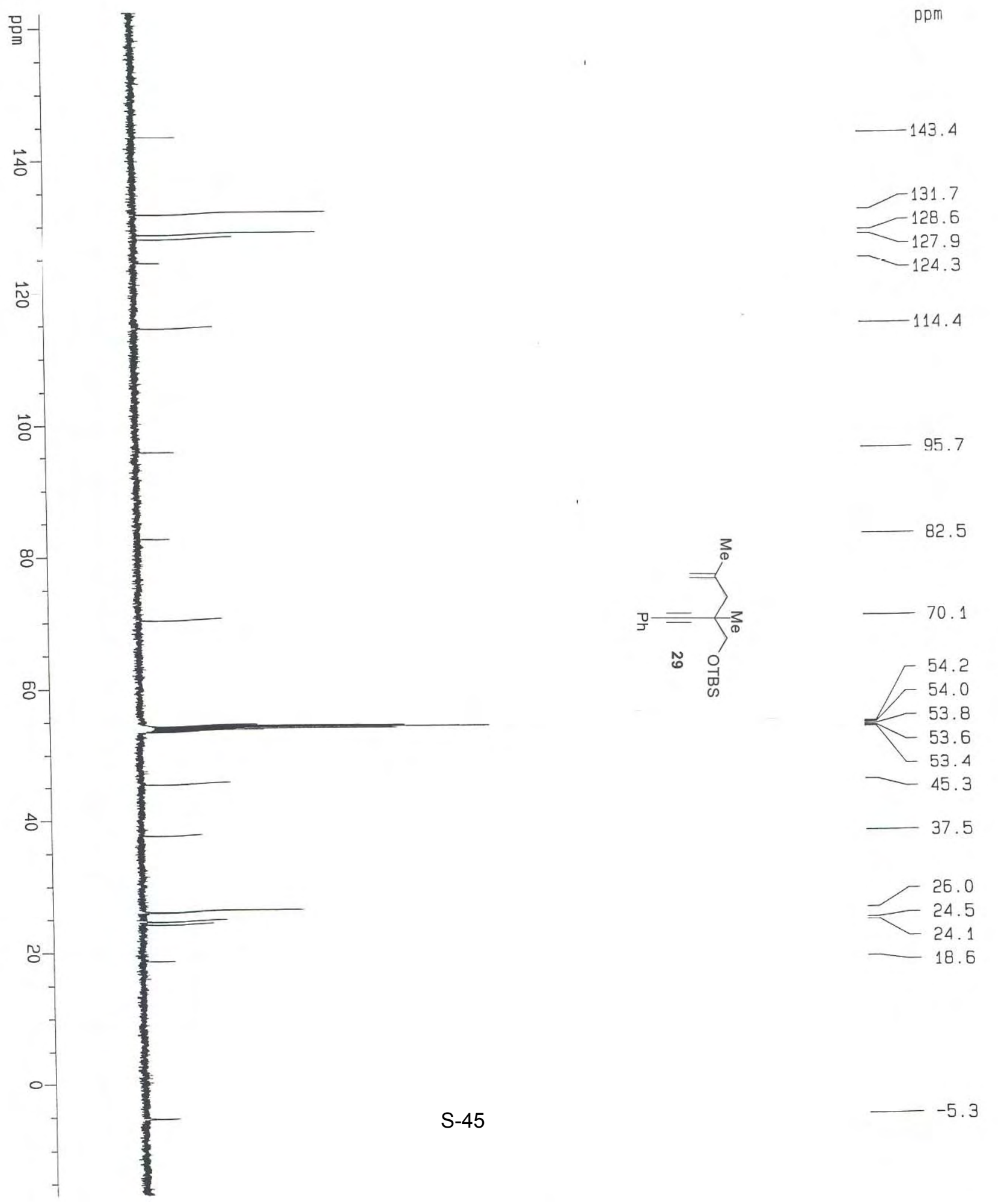




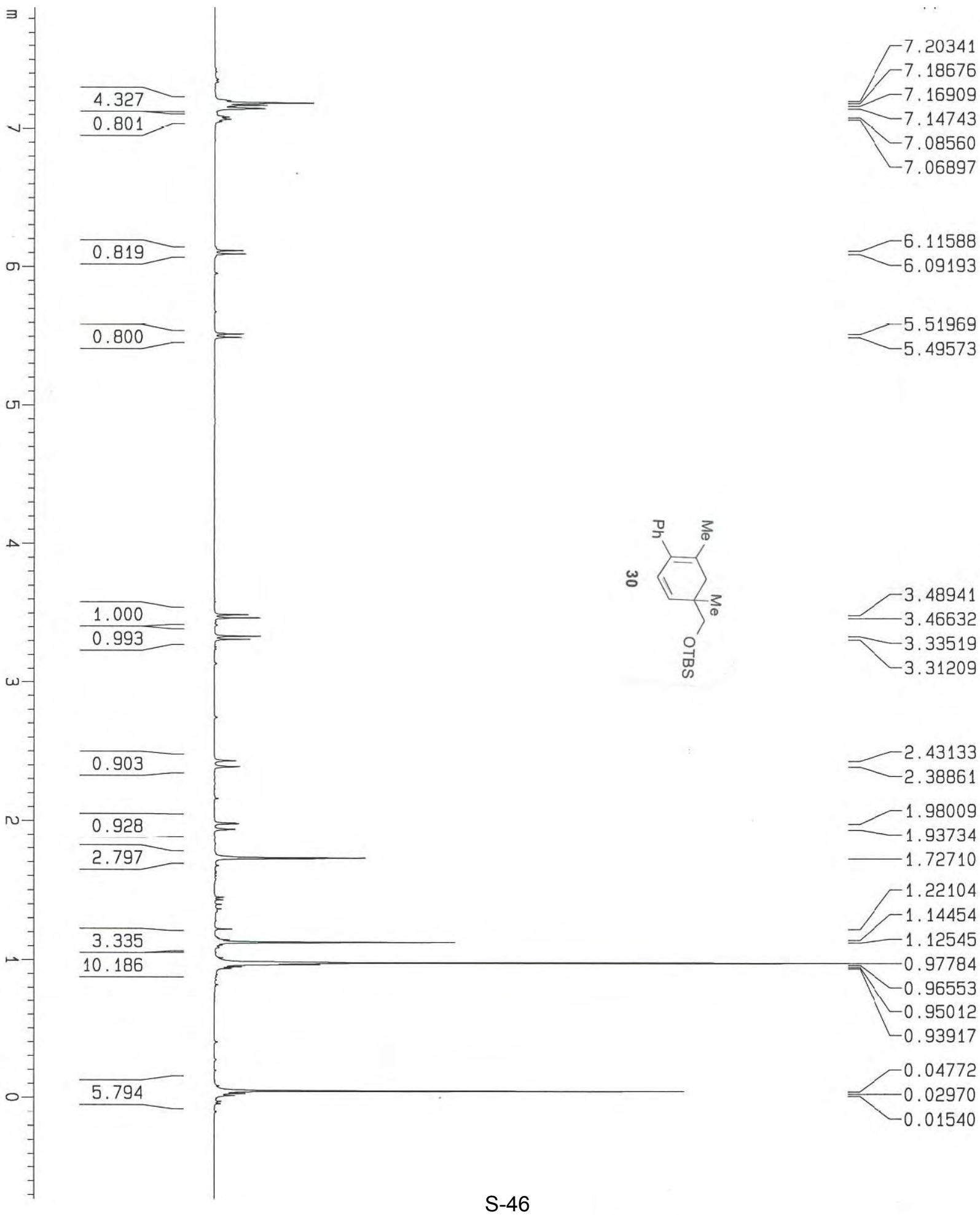

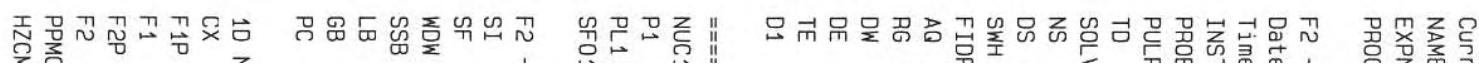




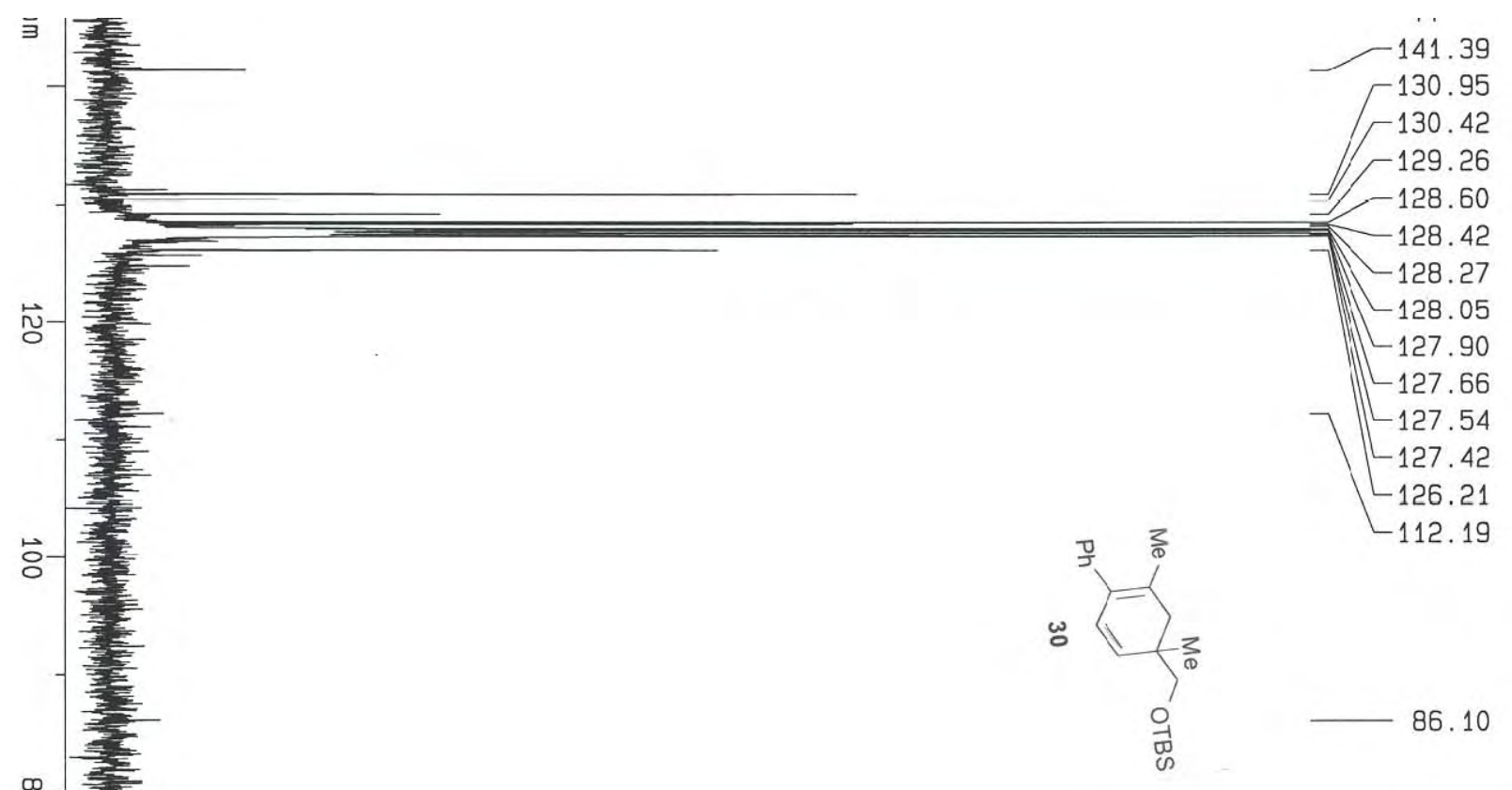

68.86

54.39

40.05

39.58

36.85

36.60

32.77

29.83

25.78

25.64

22.94

20.67

19. 24

18. 24

15.51

13.93

5.75

$-4.87$

$-5.65$

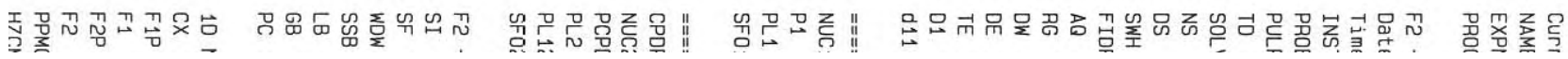



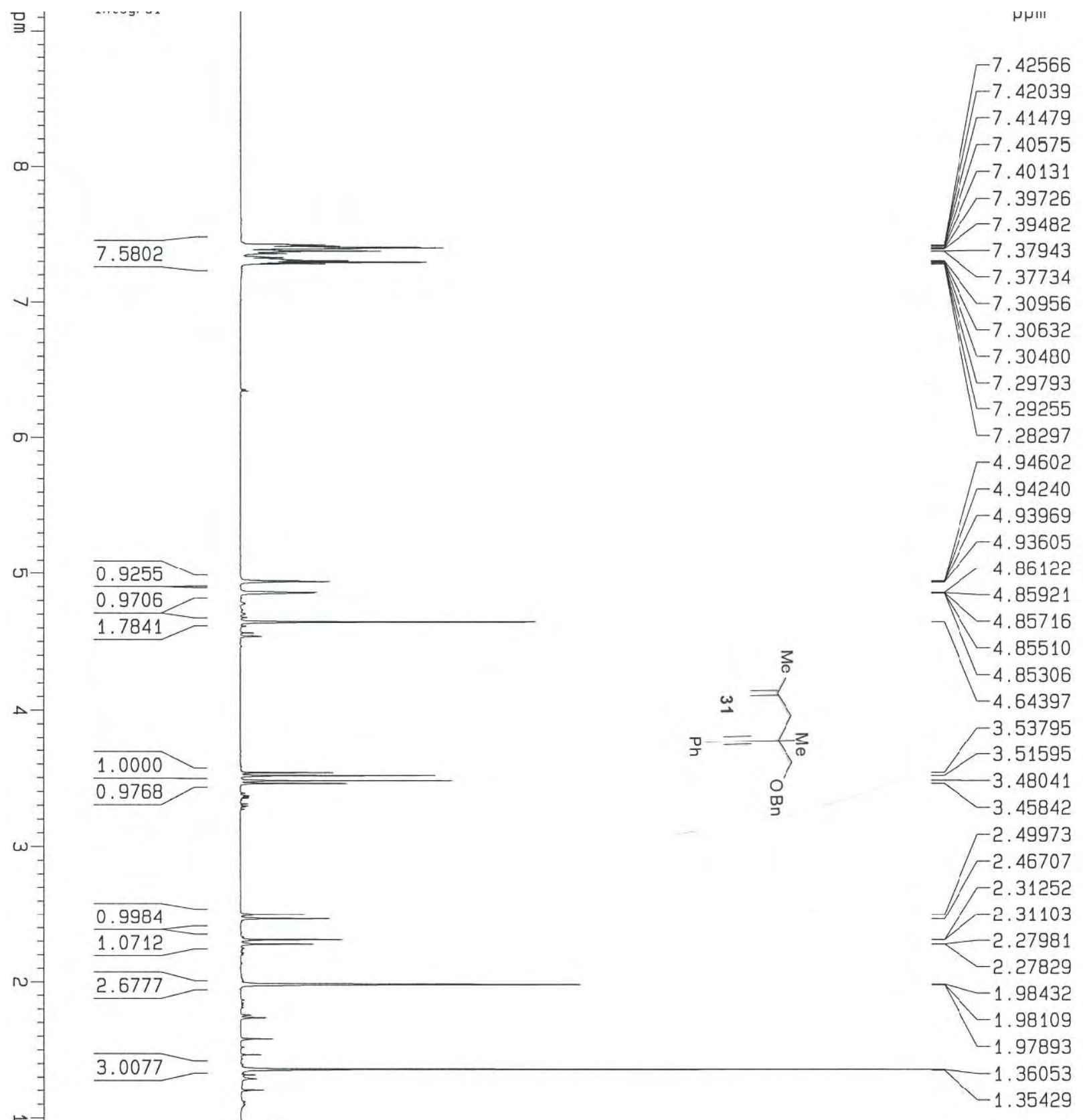

ก
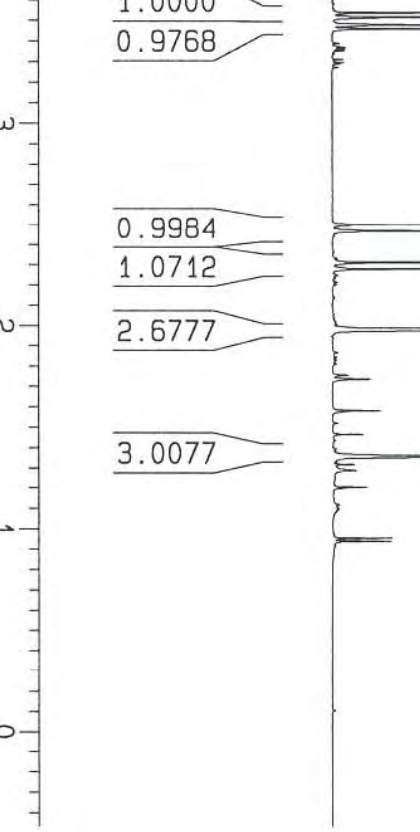


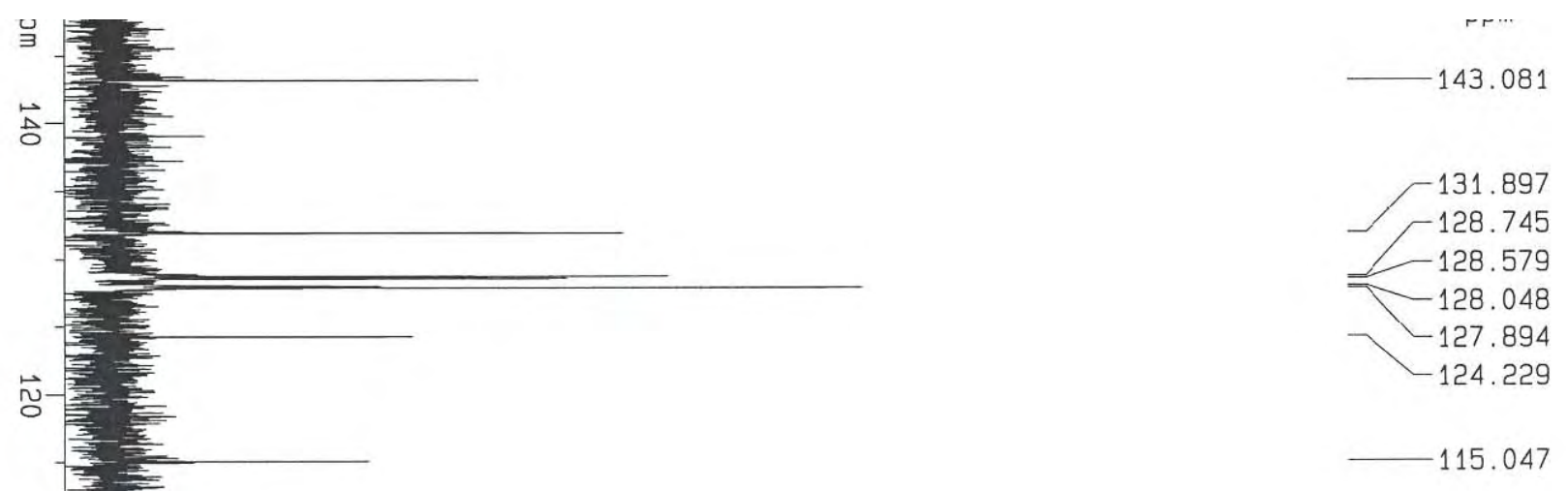

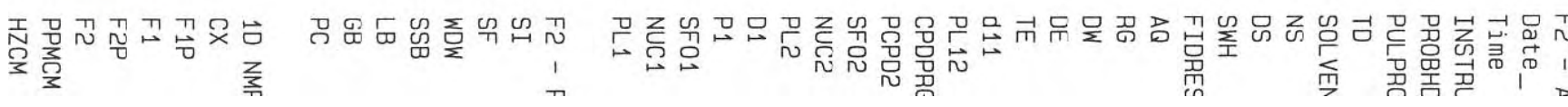



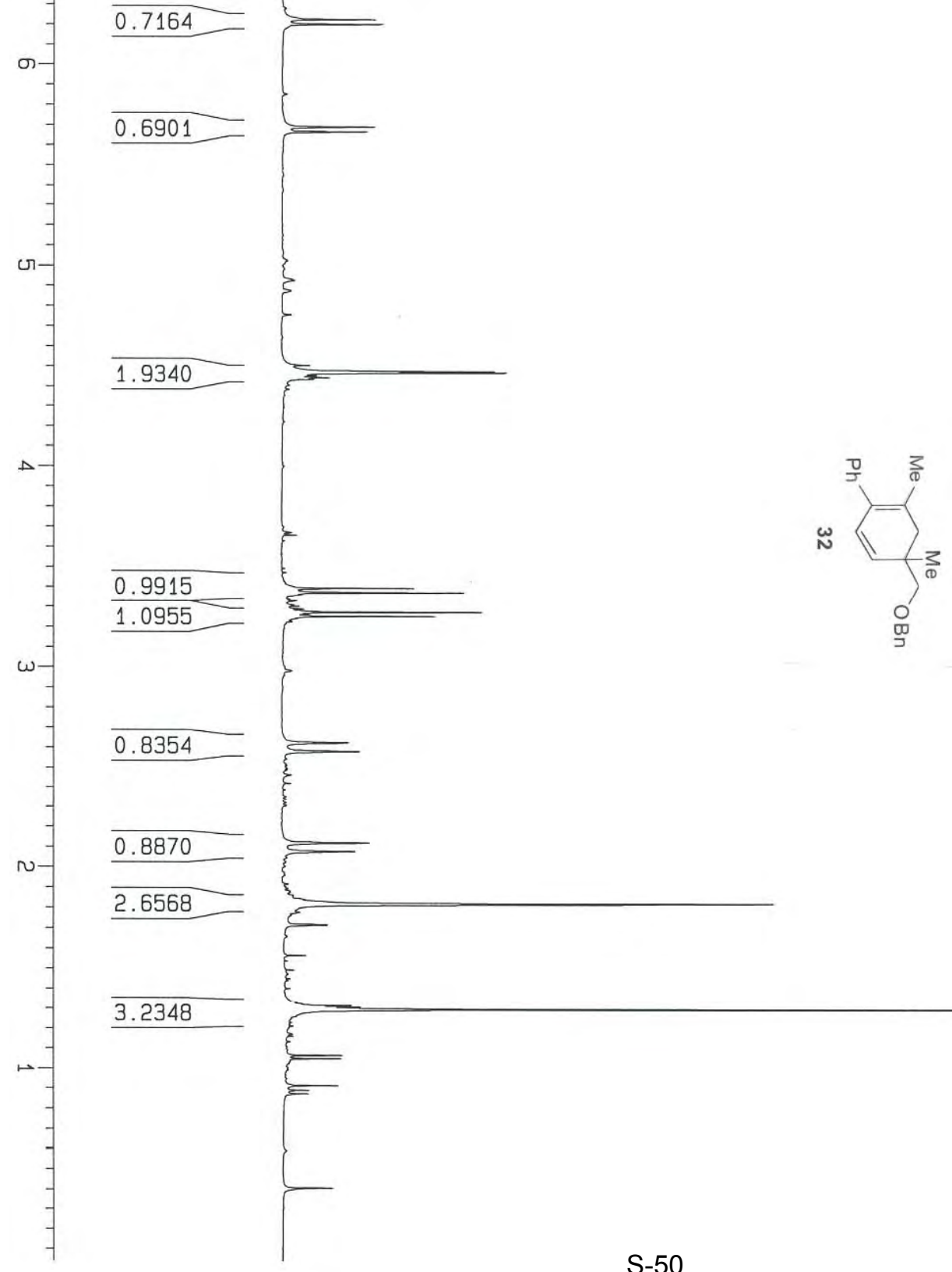

4.47196 

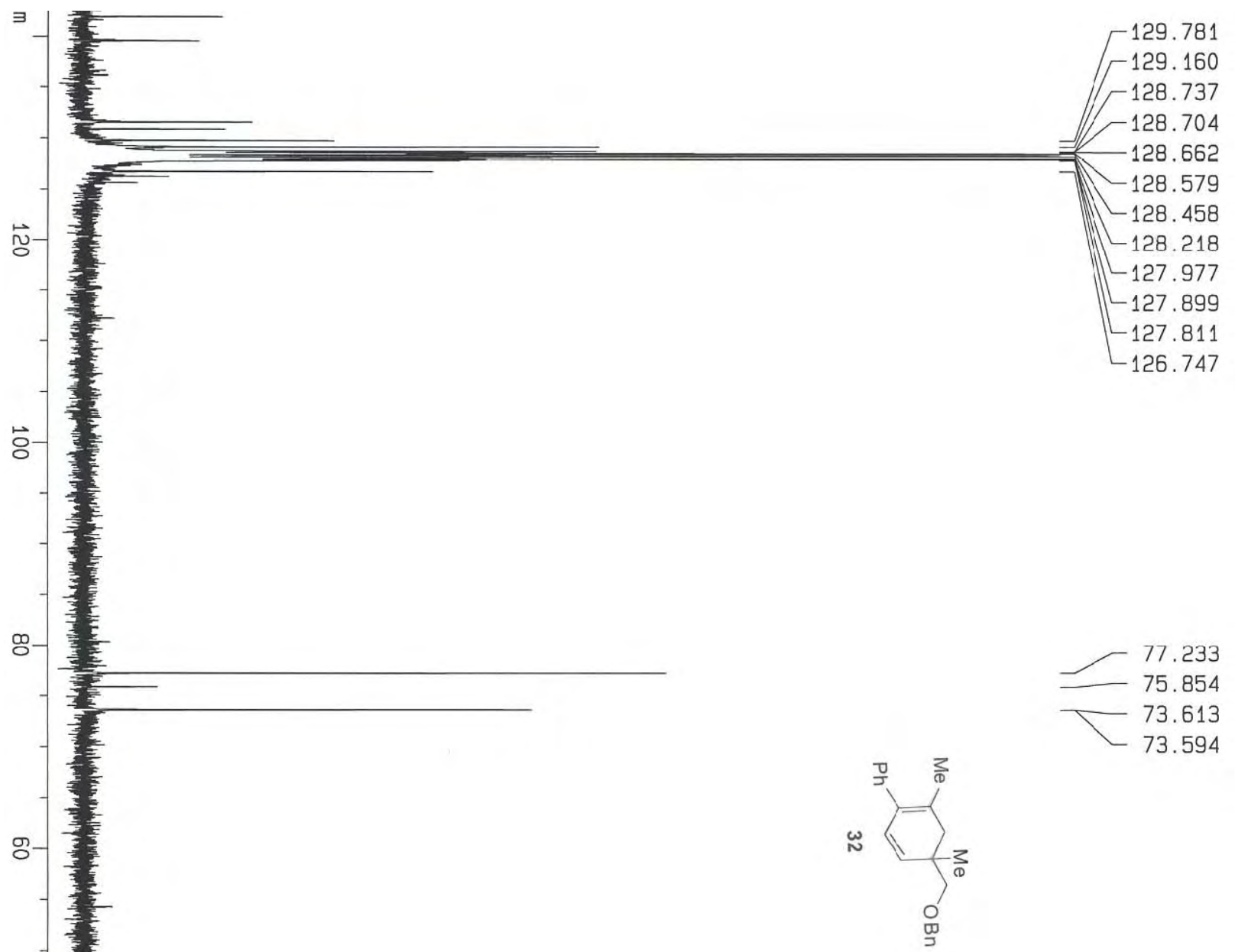


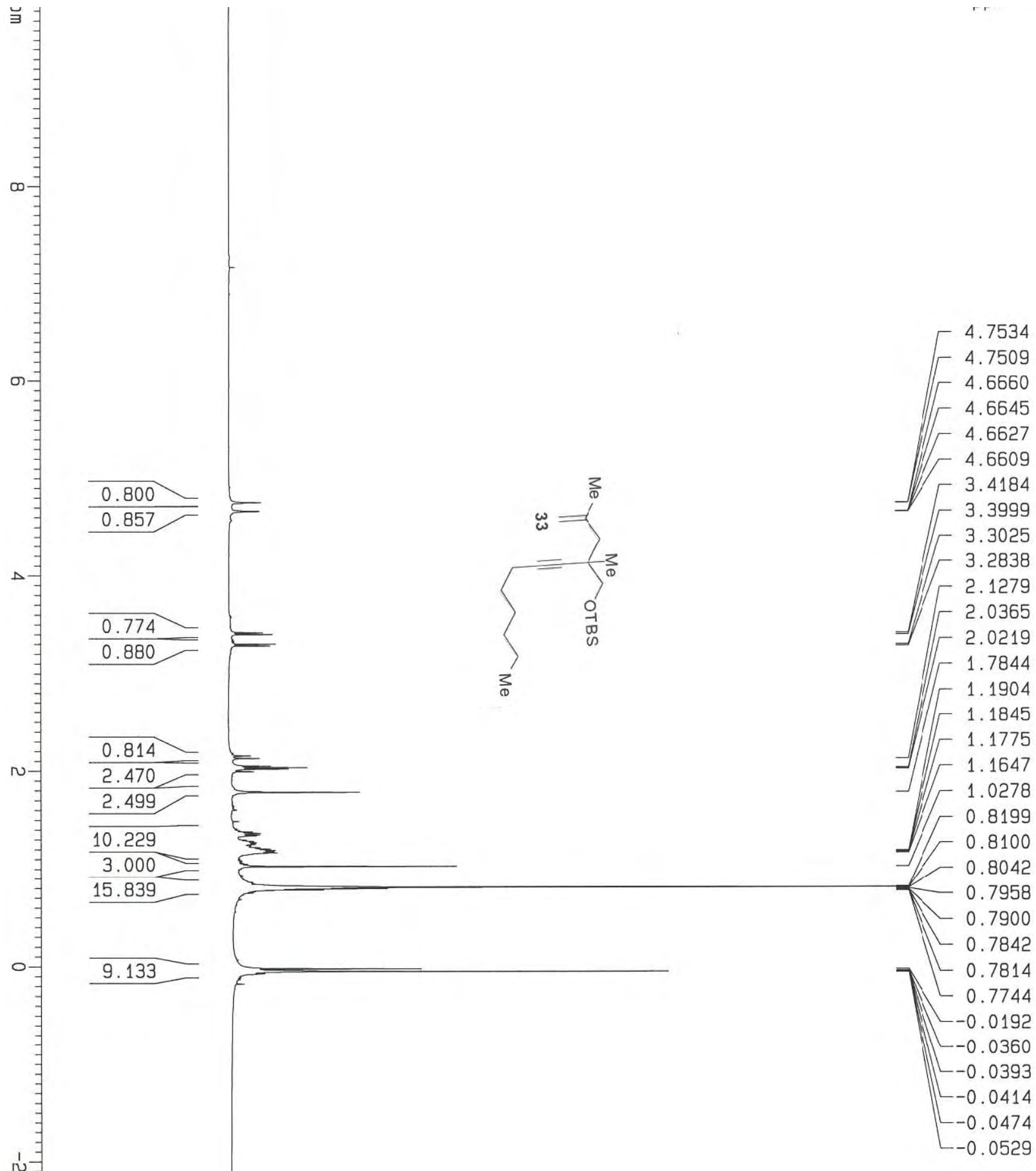




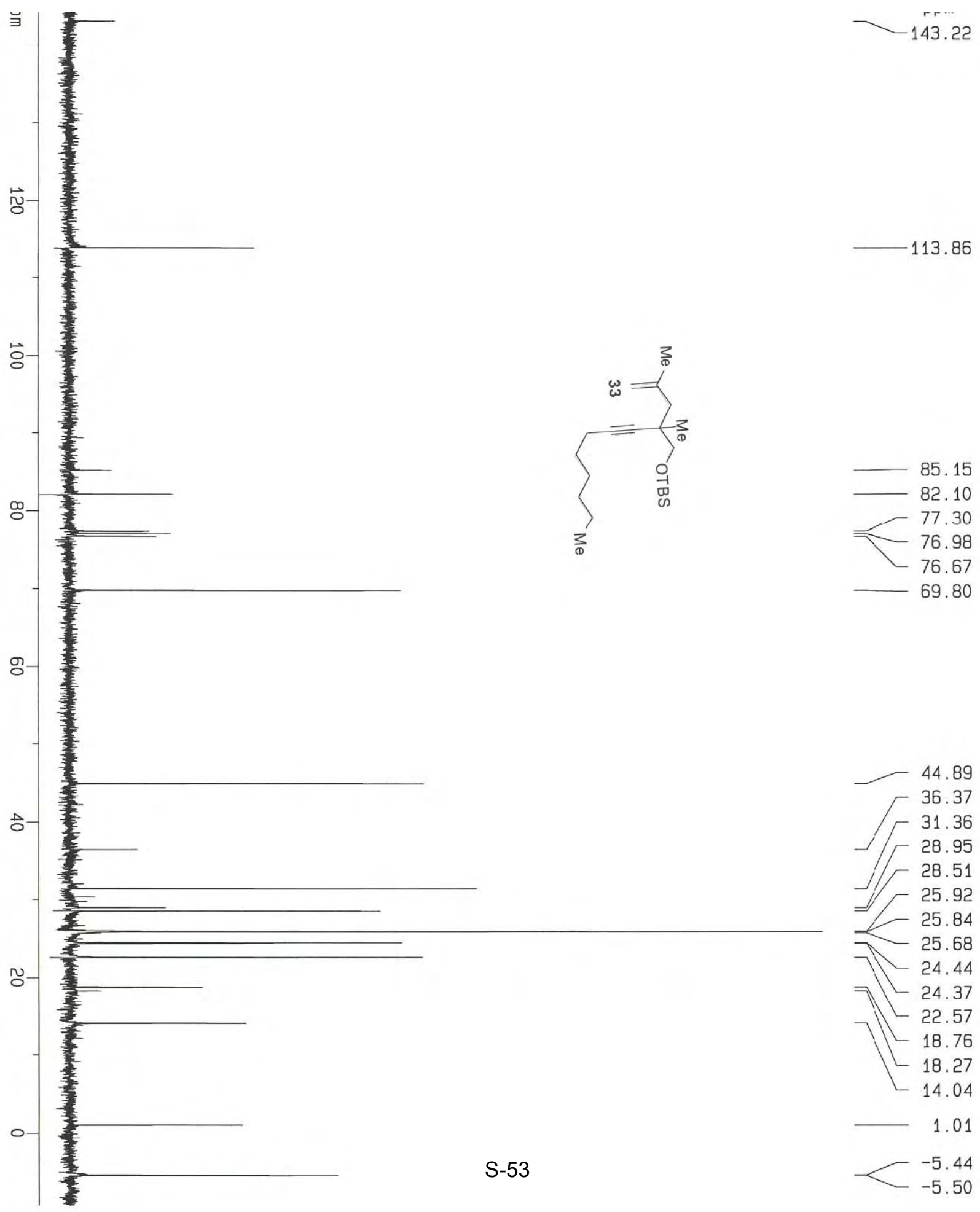




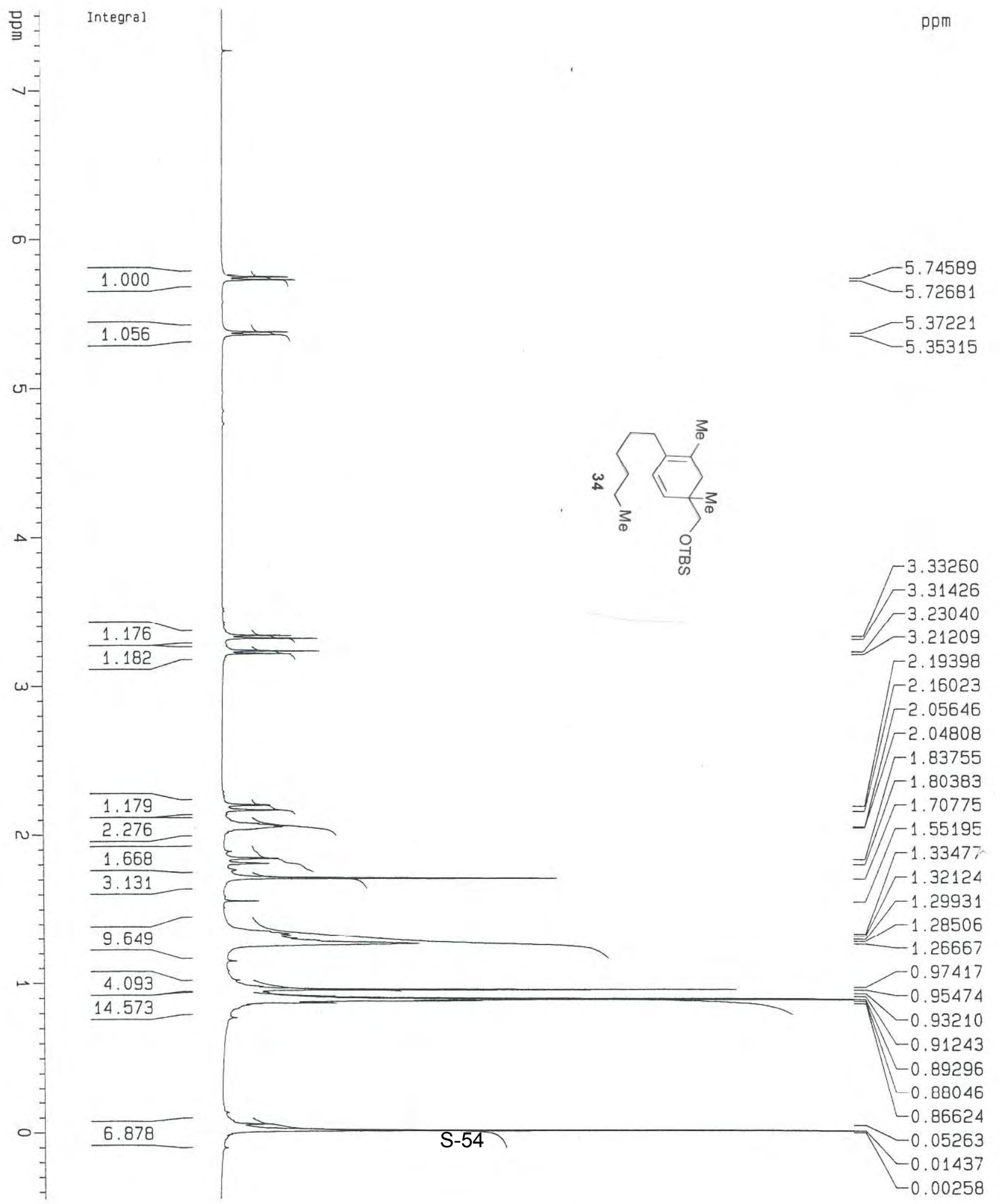




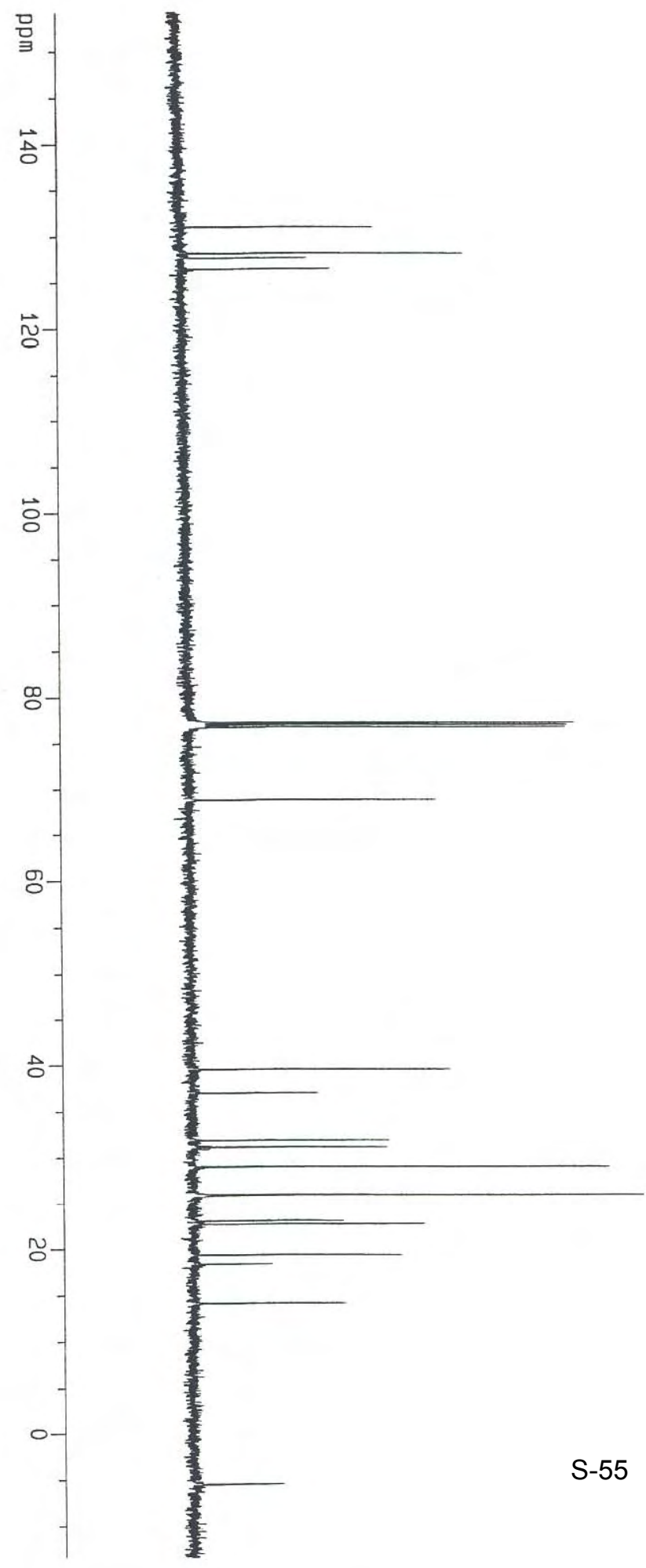

$-77.3$

77.0

76.7

68.7

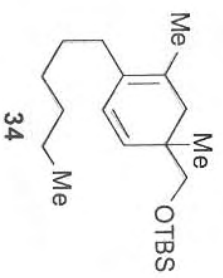

39.5

37.0

31.8

31.1

29.0

25. 9

23.0

22. 7

19.3

18. 3

14.1 


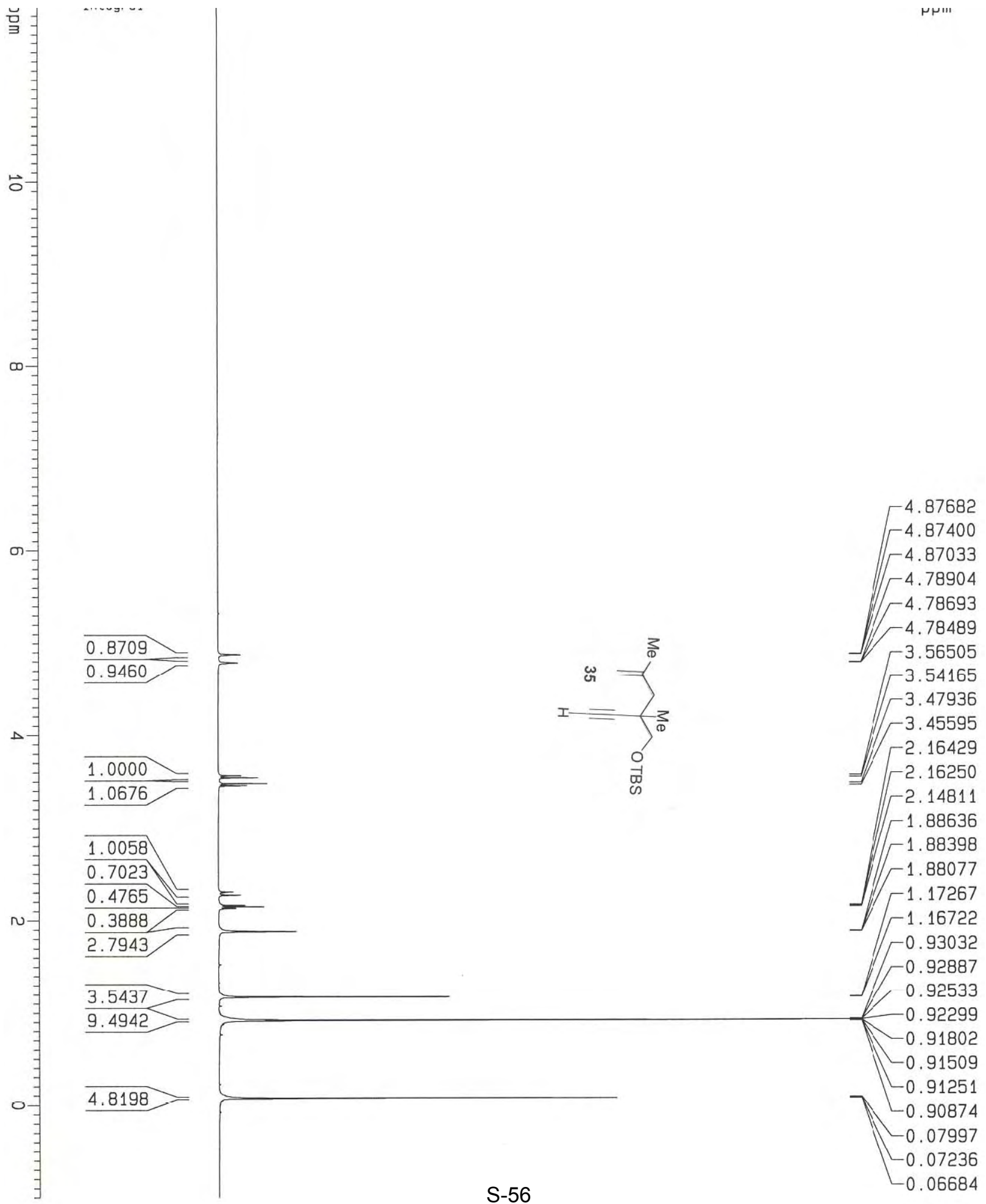




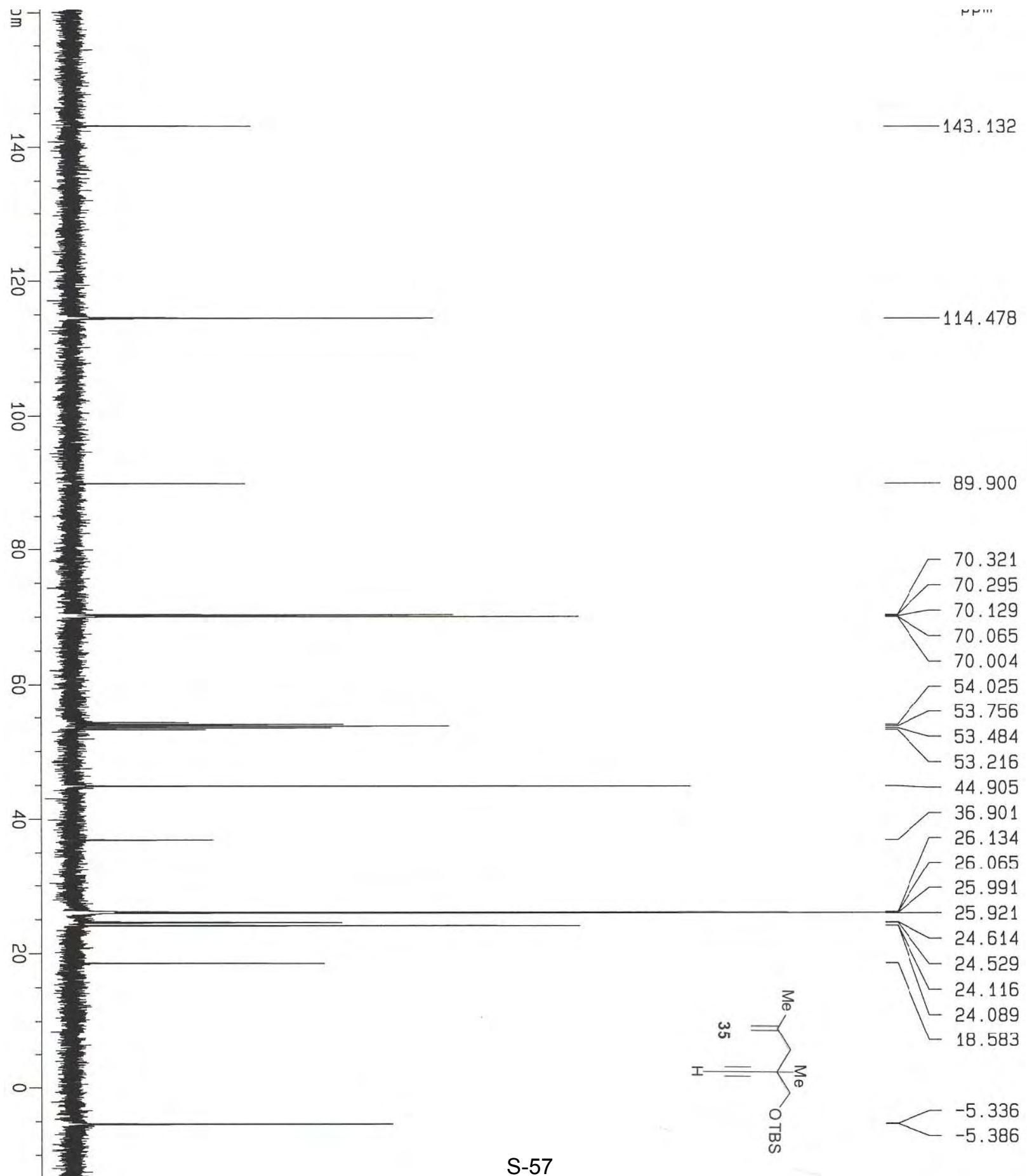




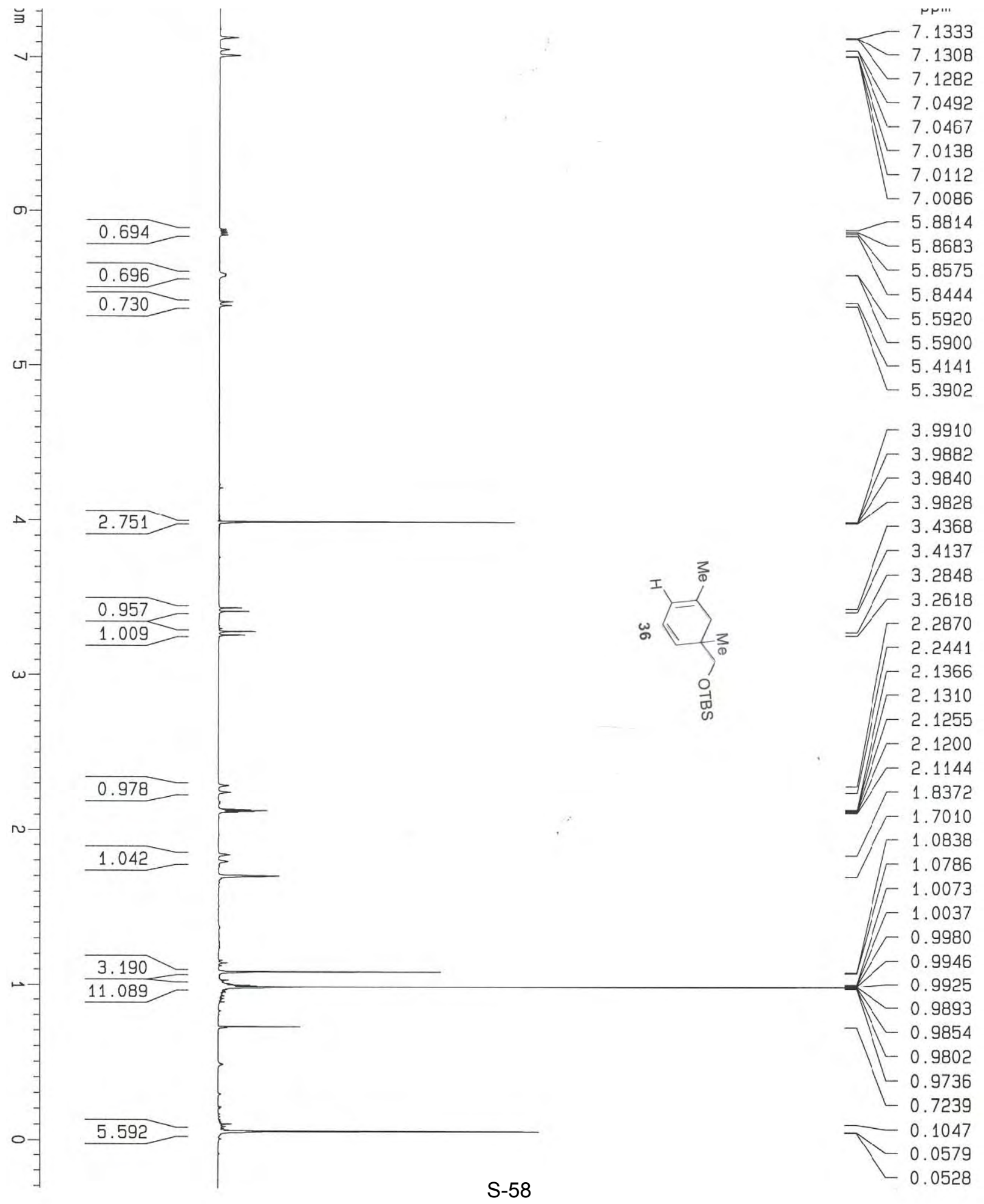




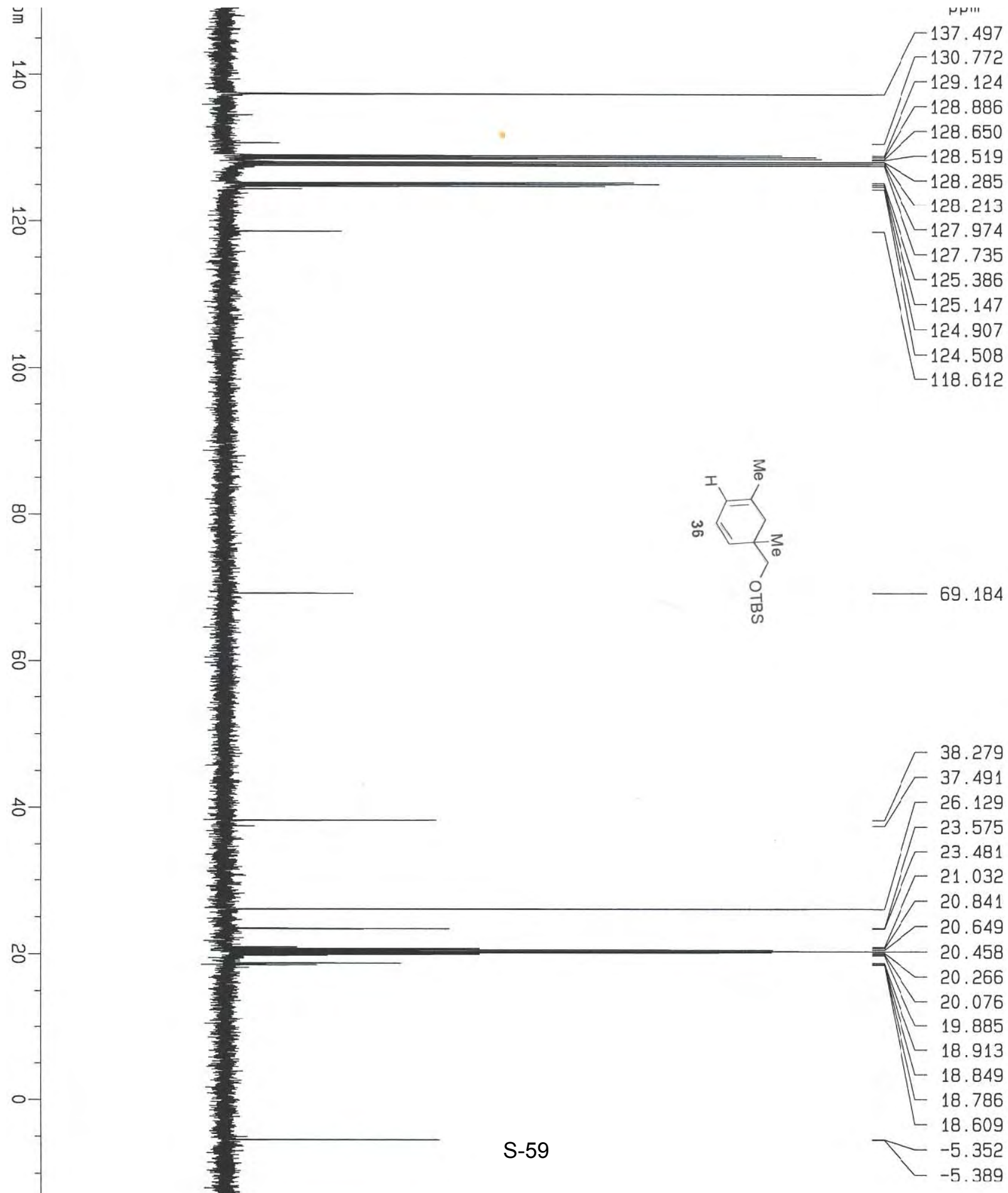




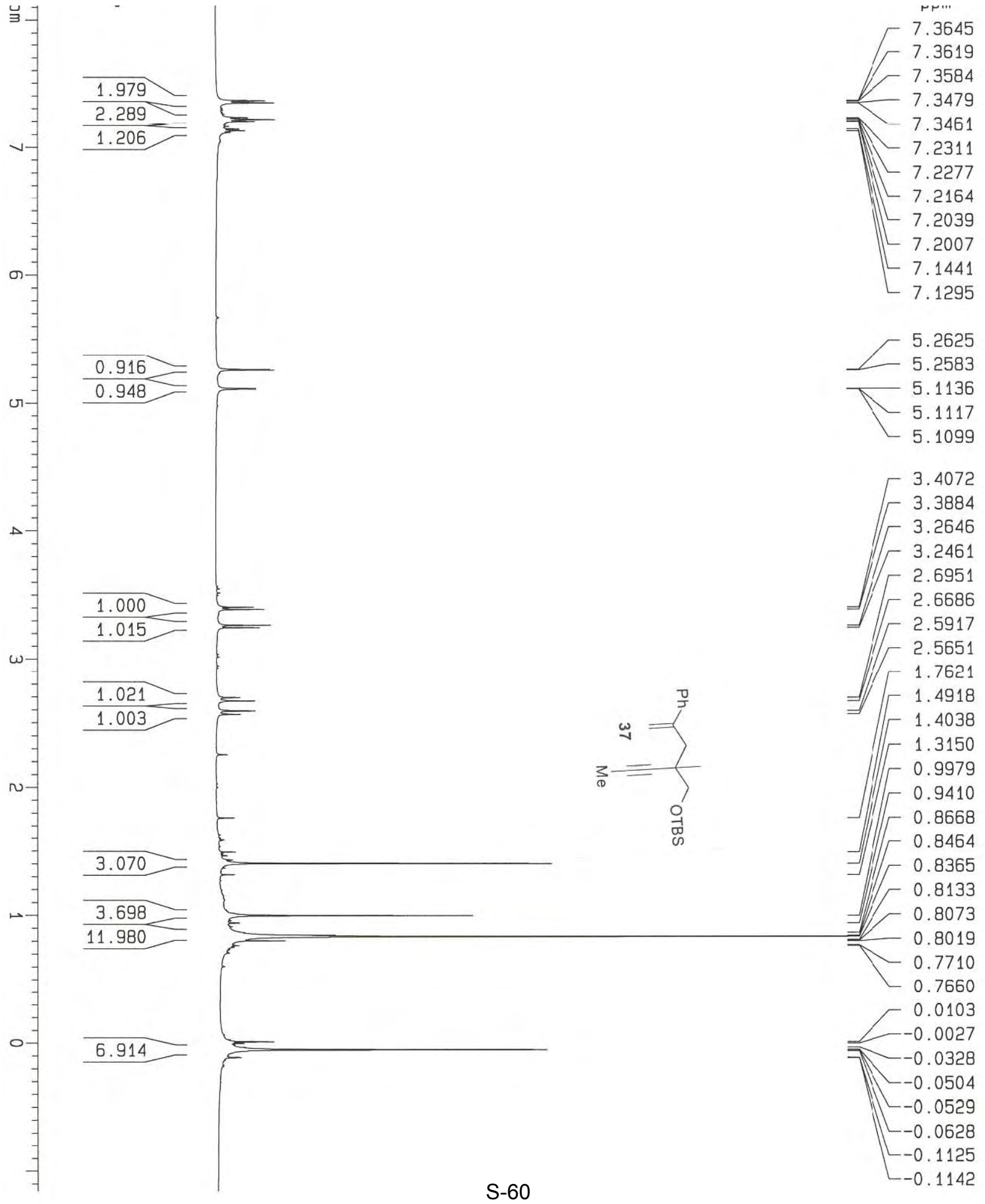



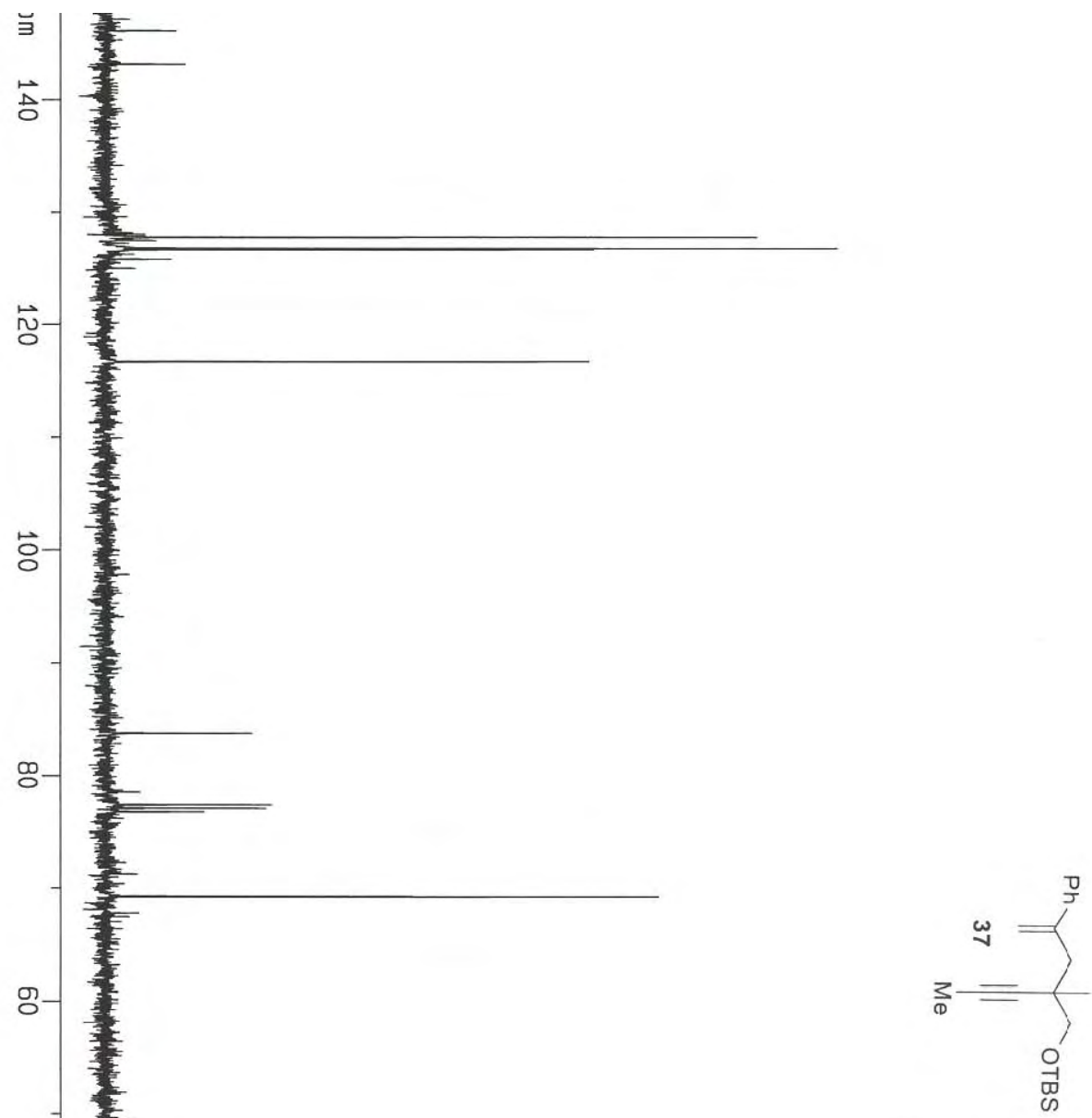

83.77

77.35

77.04

76.72

69.26

41.84

37.28

o-

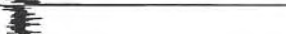

$-25.91$ 24.26

18. 32

3.23

$-5.41$

$-5.48$ 


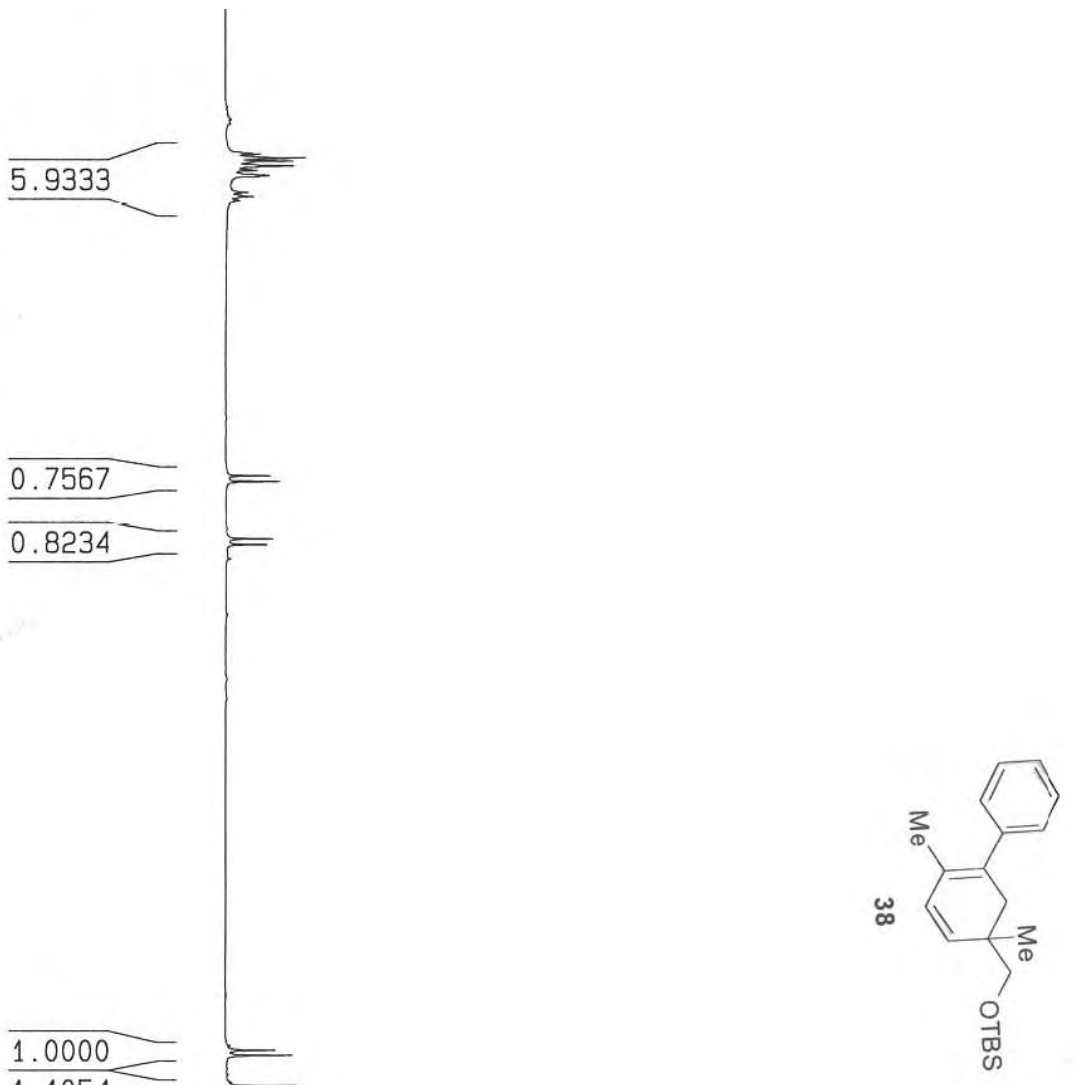

3.62049 $-3.59740$ 3.47088 $-3.44781$ $-2.87801$ - 2.84125 $-2.83654$ $-2.42087$ $-2.41619$ $-2.37946$ $-1.85251$ $-1.84799$ $-1.84344$ $-1.27080$ $-1.24816$ $-1.09747$ $-1.09556$ $-1.09406$ $-1.09234$ $-1.08676$ 1.08524 1.08230 $-1.08099$ $-1.07501$ $-1.07145$ $-1.06974$ $-1.06842$ $-0.15226$ $-0.13945$ 

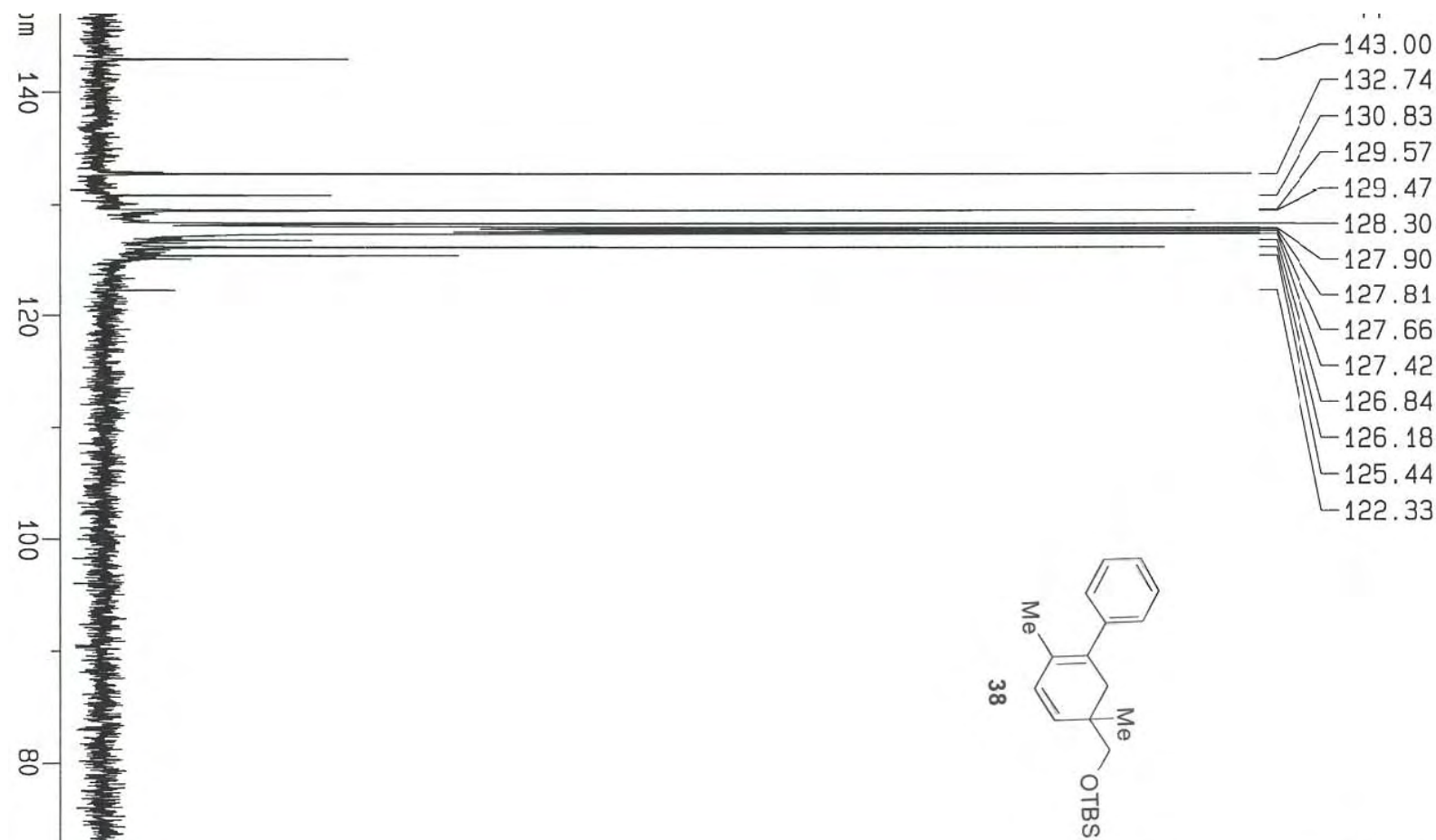

68.74

68.55

g)

음

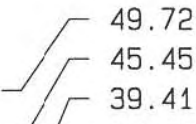

39.30

37.29

32.64

32.52

27.49

25.75

24.37

23. 56

23. 31

22.57

22. 51

18. 29

18. 19

13.96

1.03

$-5.54$

$-5.68$ 


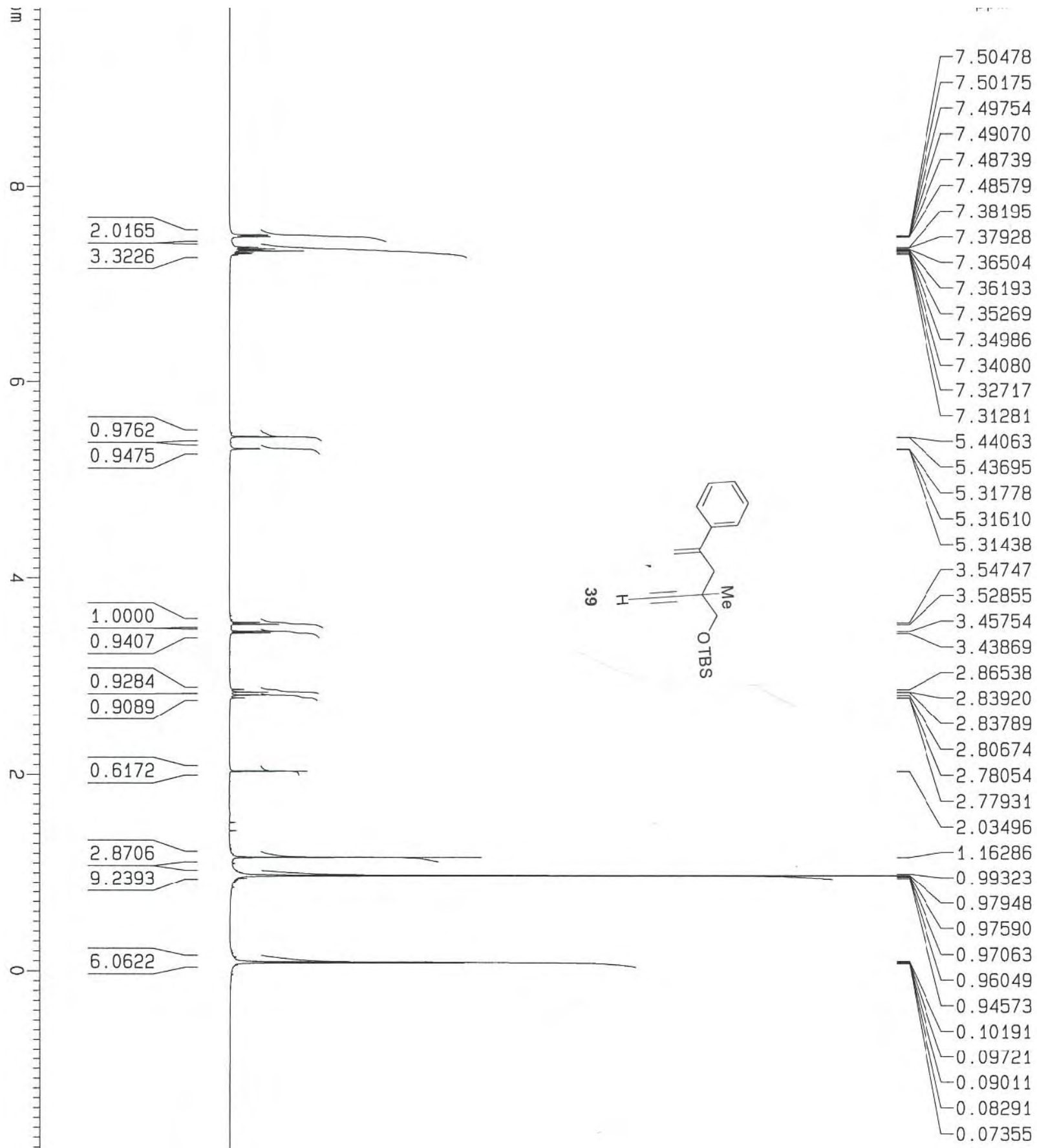



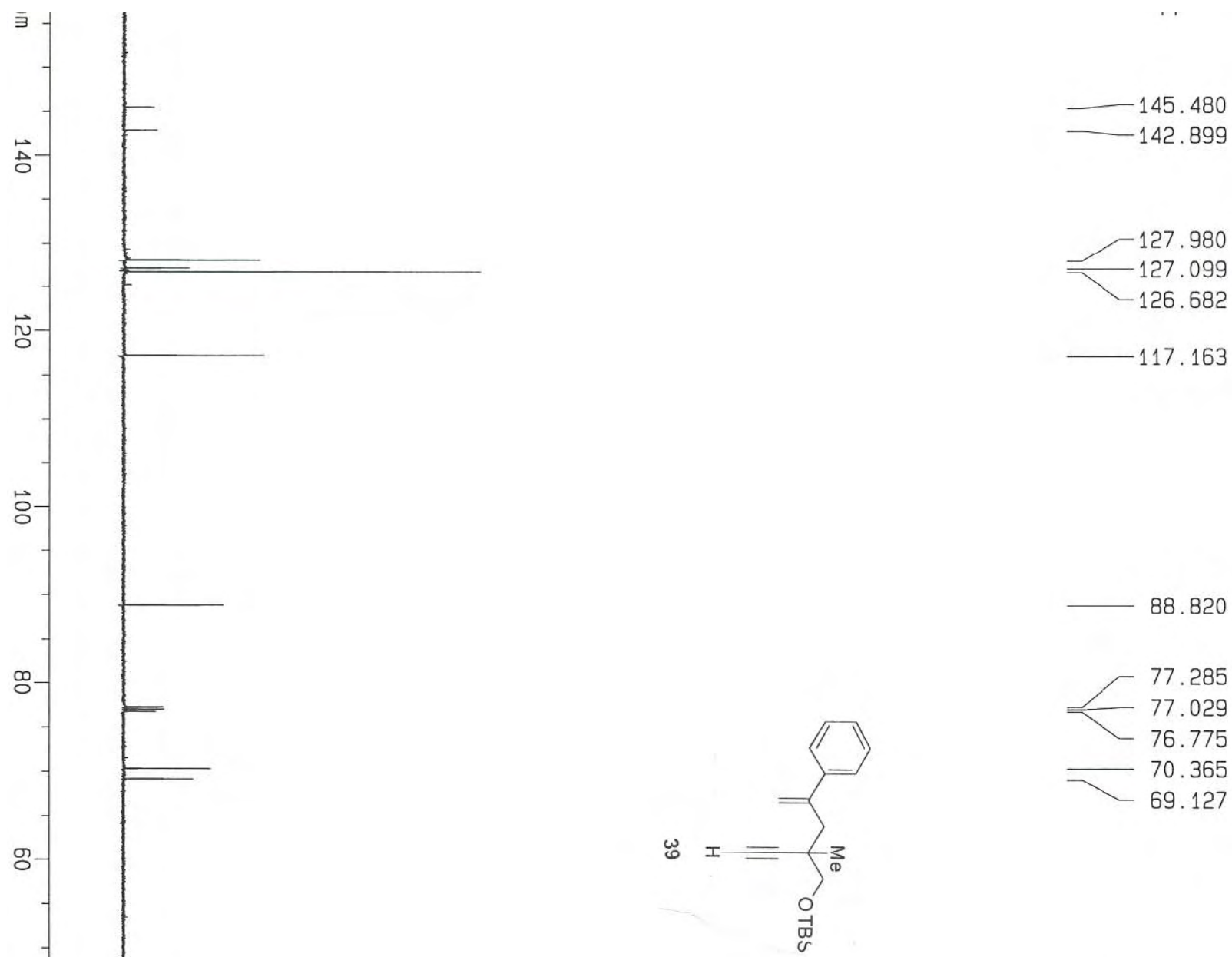

88.820

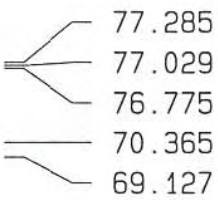

41.431

37.800

하

응

ळ

음

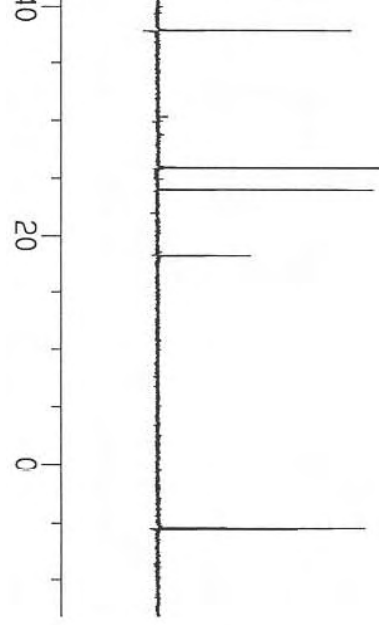




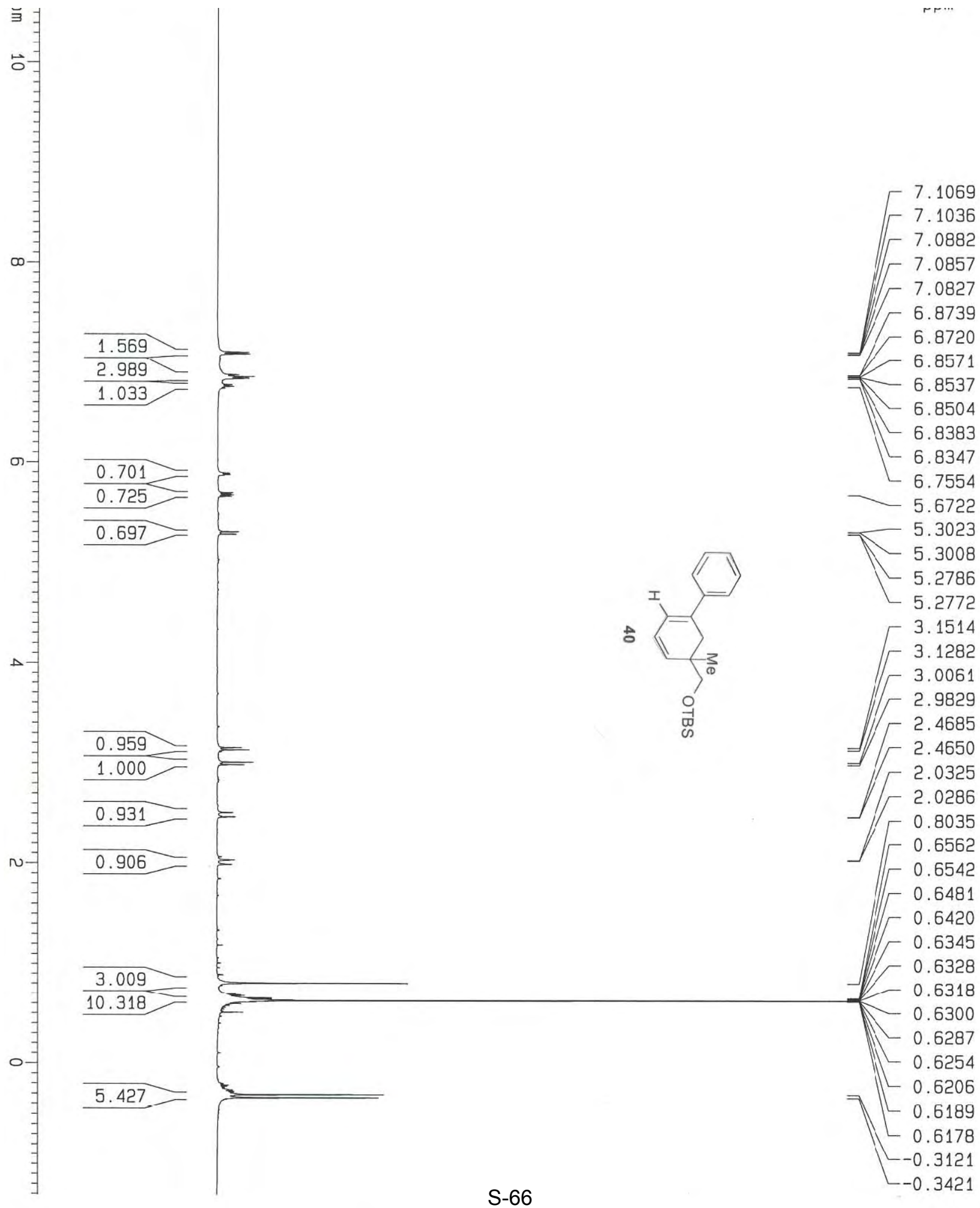




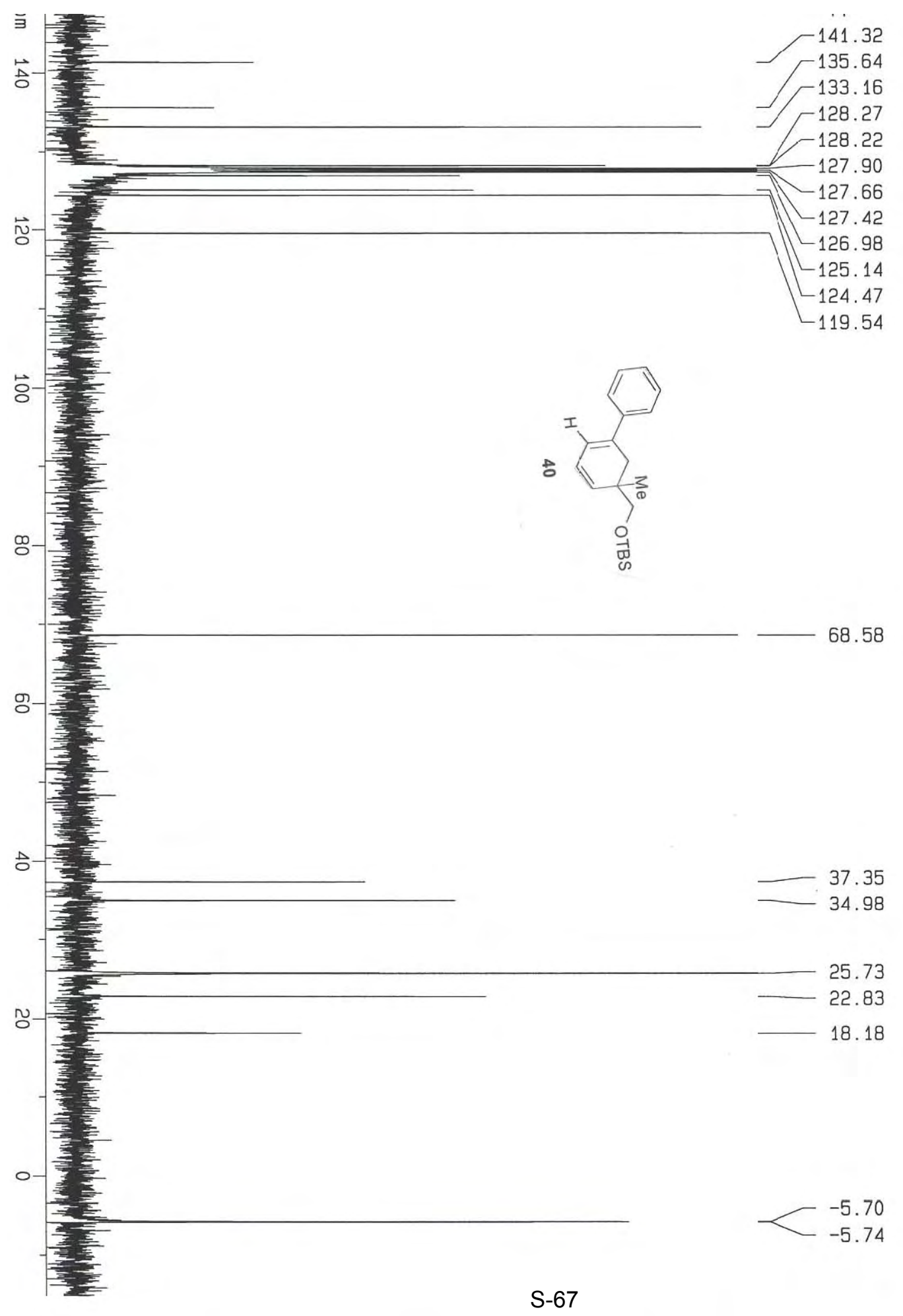




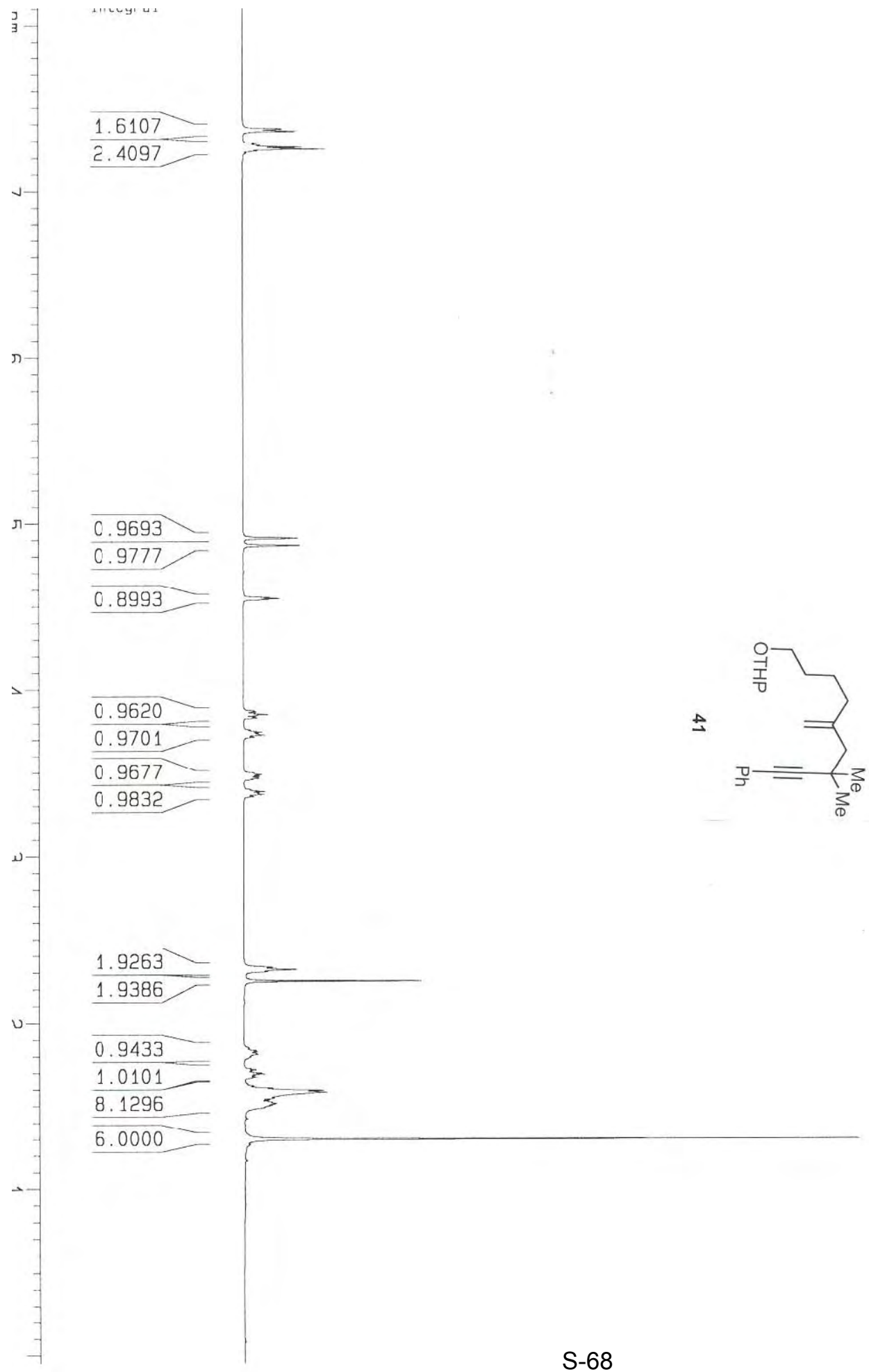




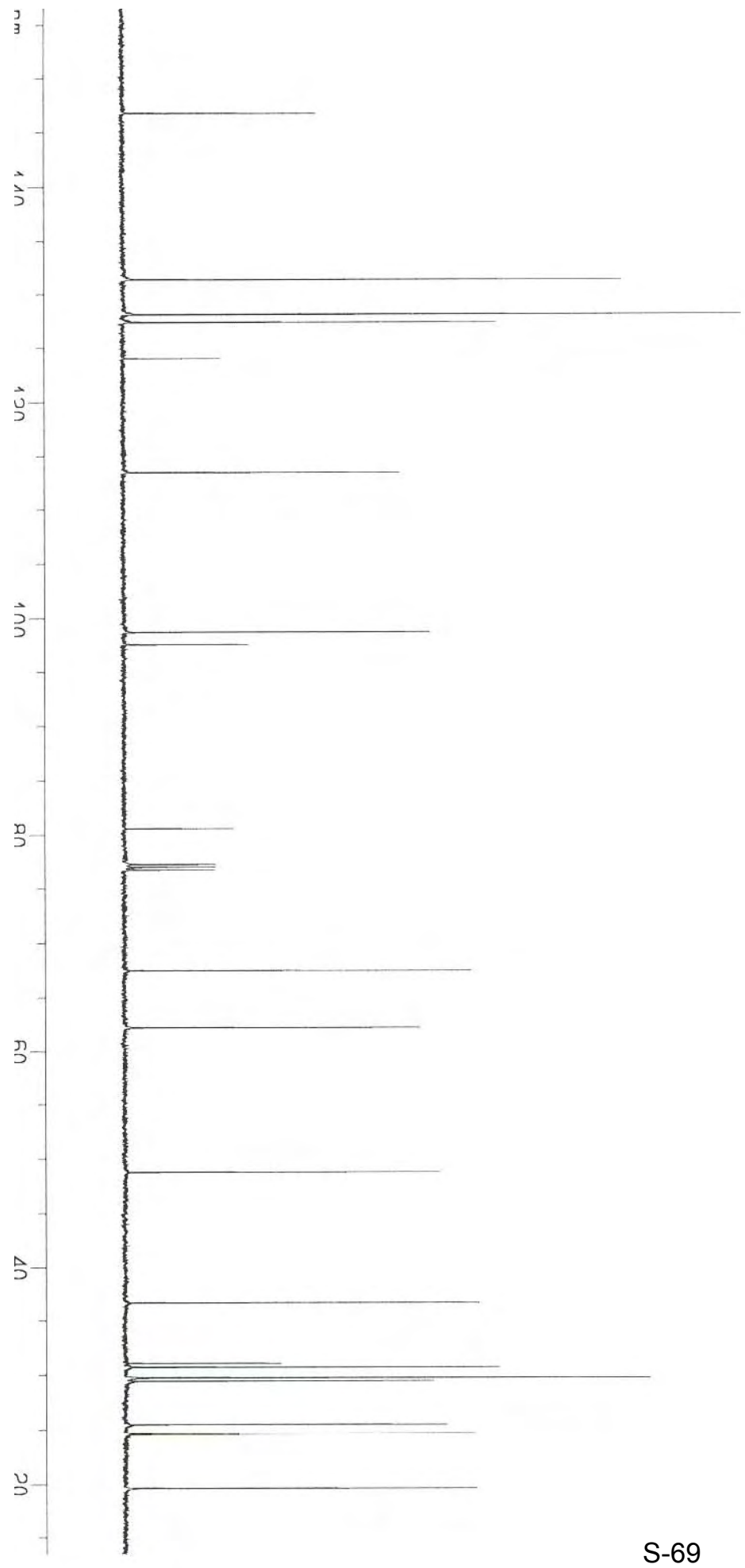

$-131.311$ $-128.085$ $-127.351$ $-123.997$

$-113.382$

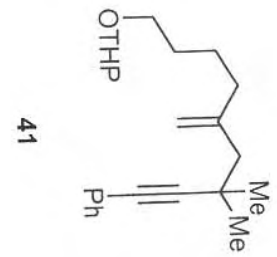

98.709 97.597

80.531

77.257 77.002 76.749

67.446 62. 195

48.740

36. 629 31.038 30.695 29. 722 29. 410 25.446 24.583 19.597 


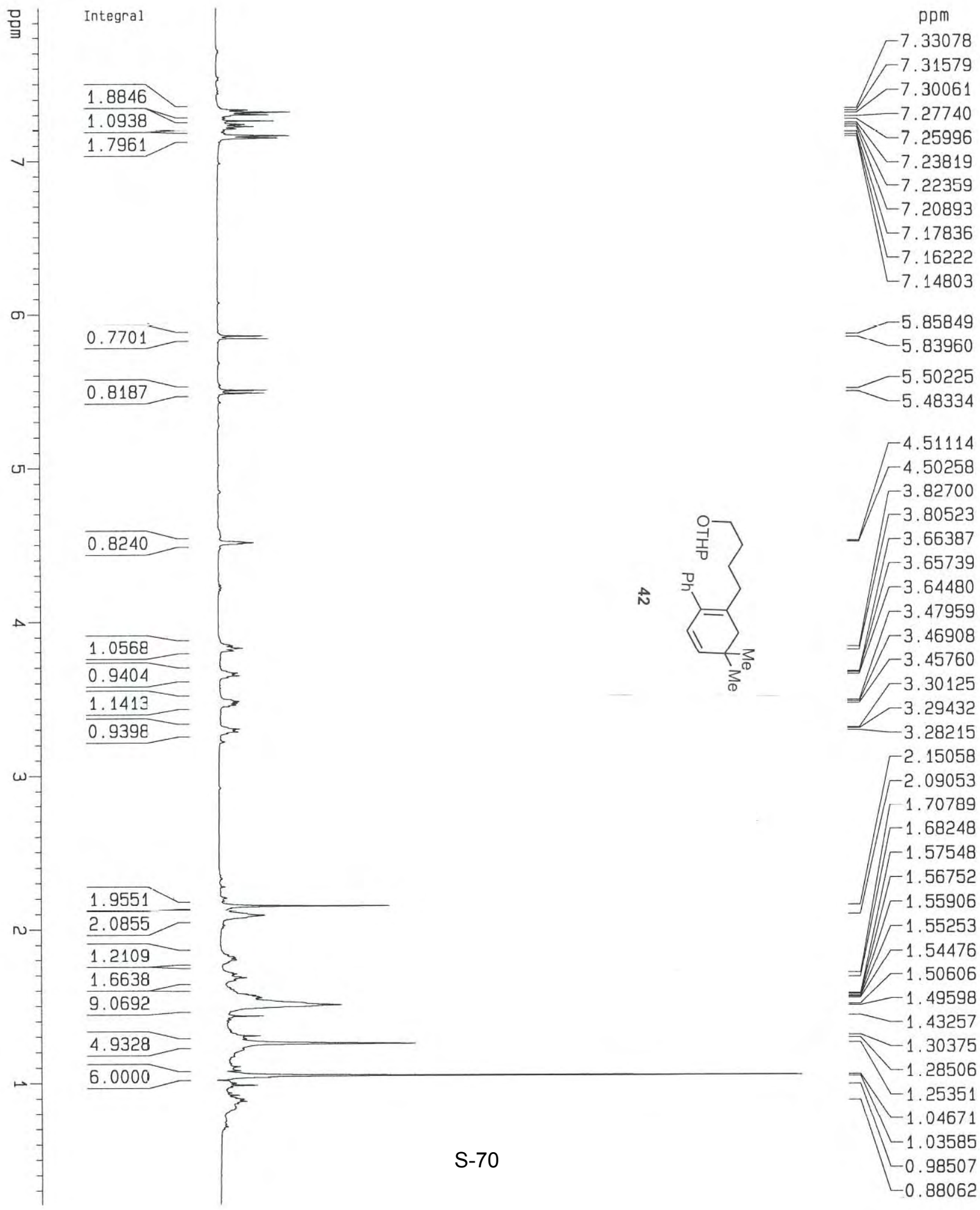




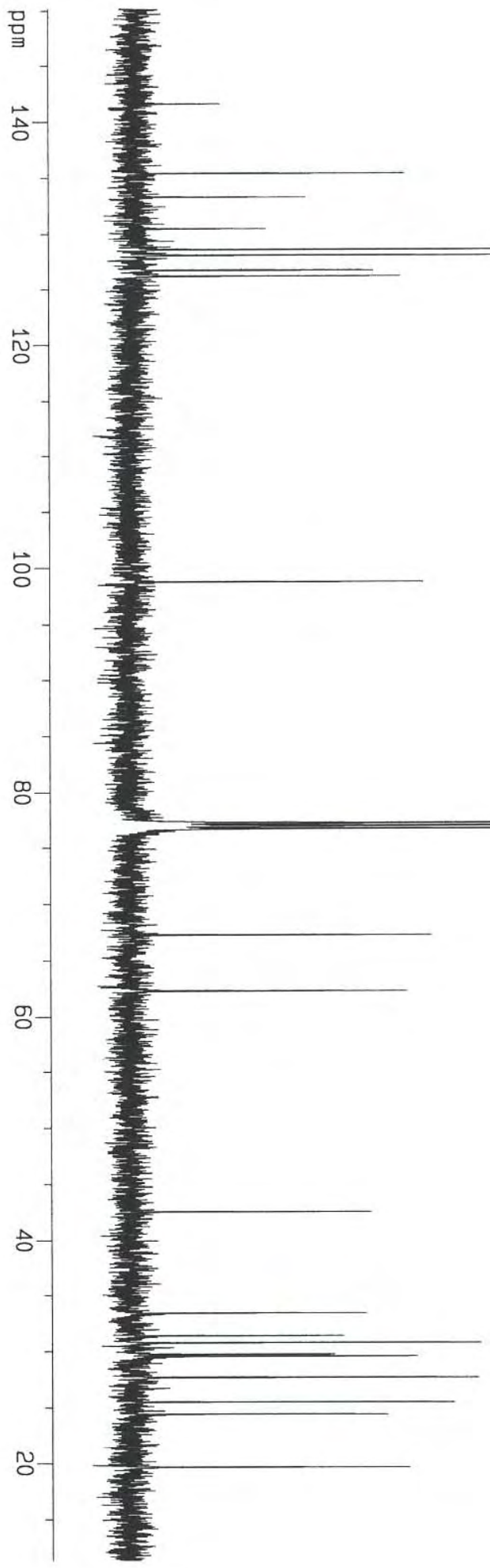




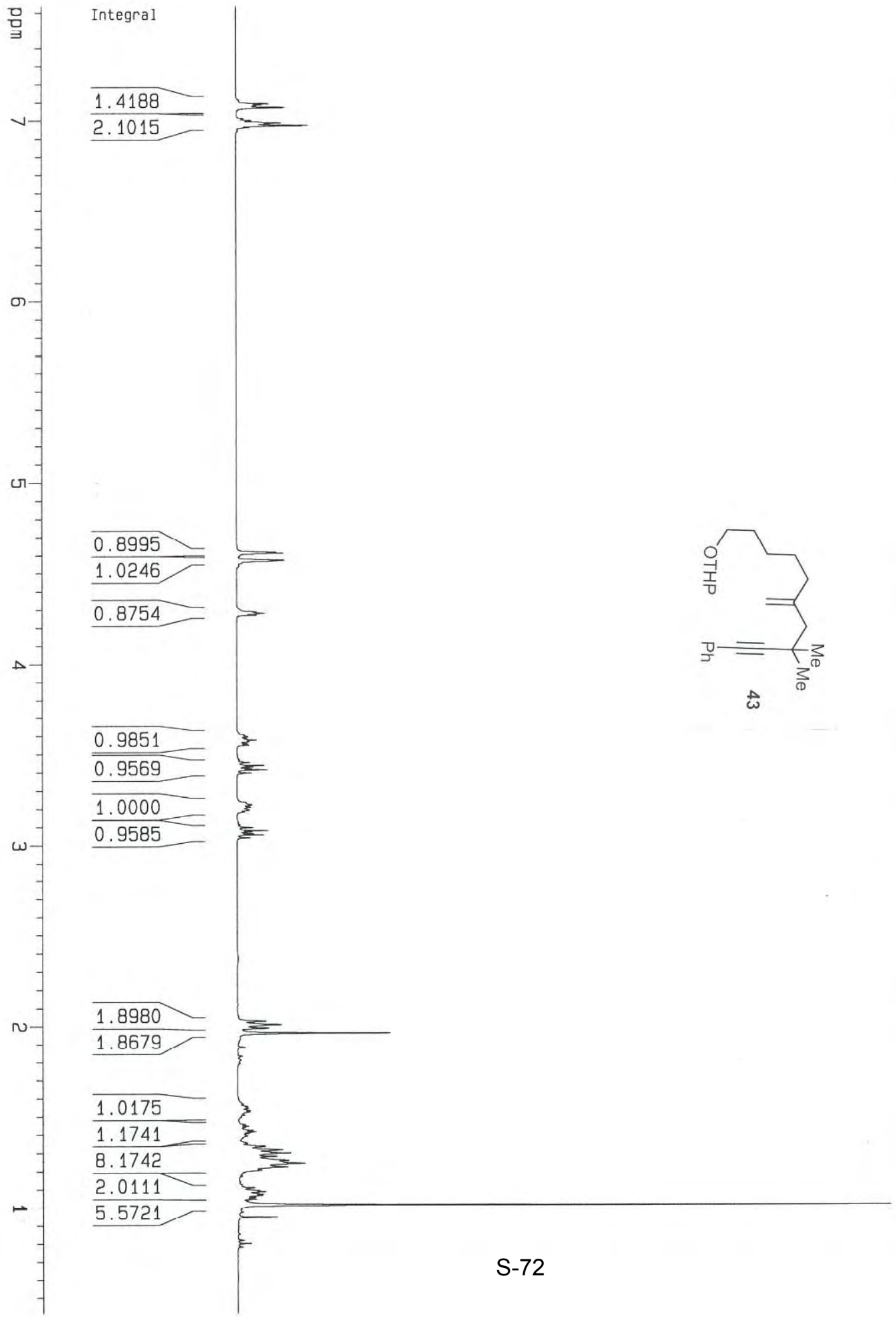



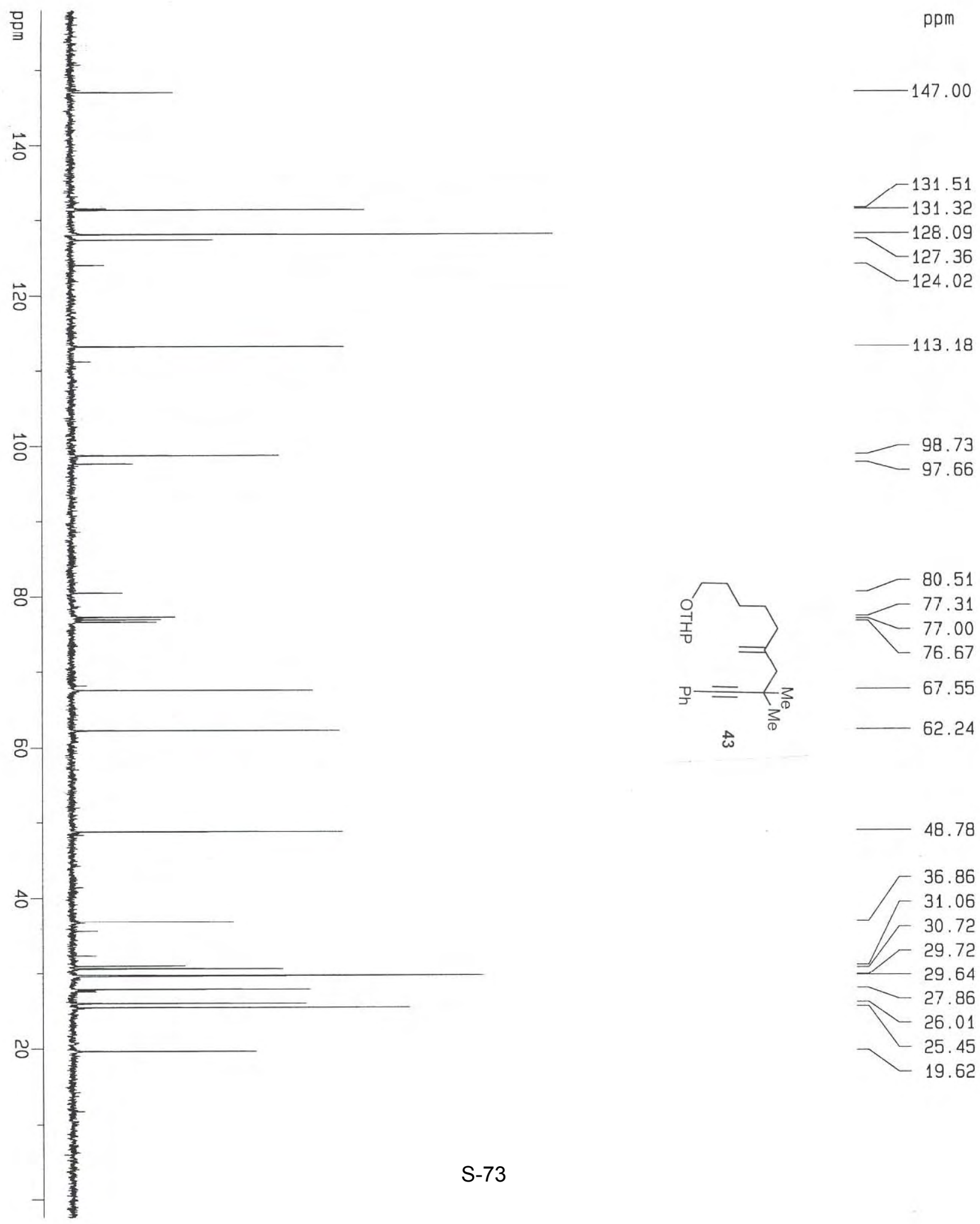


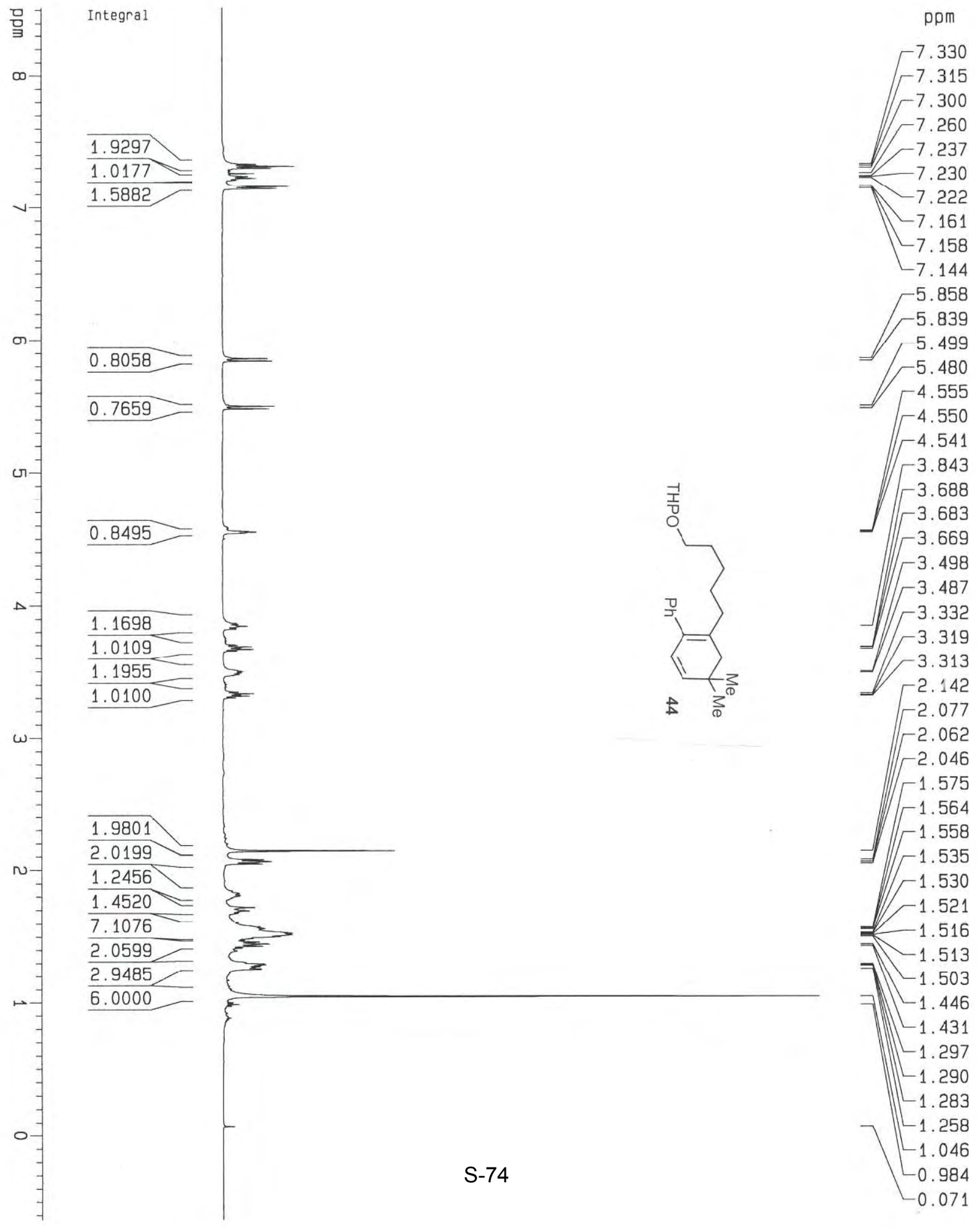



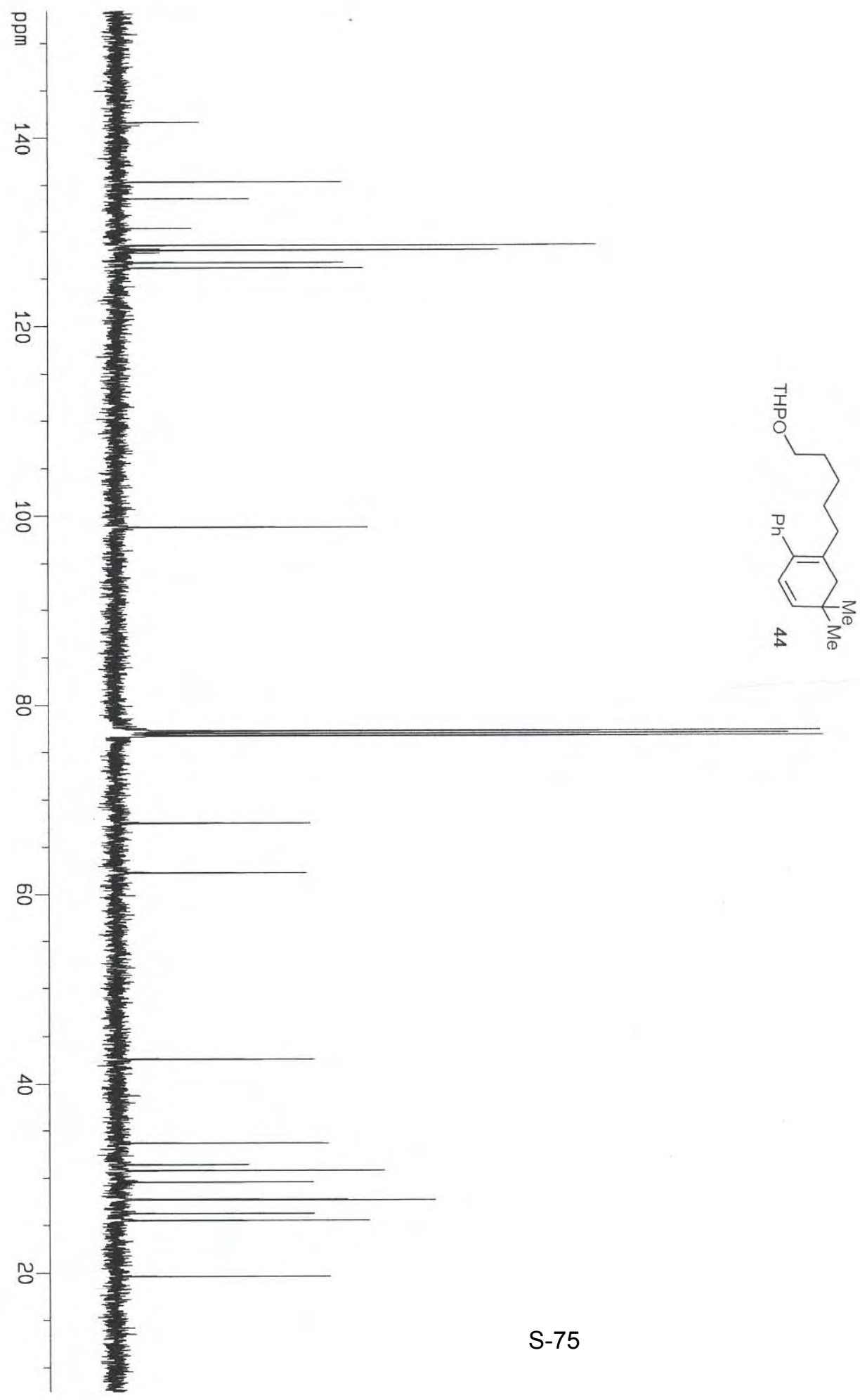

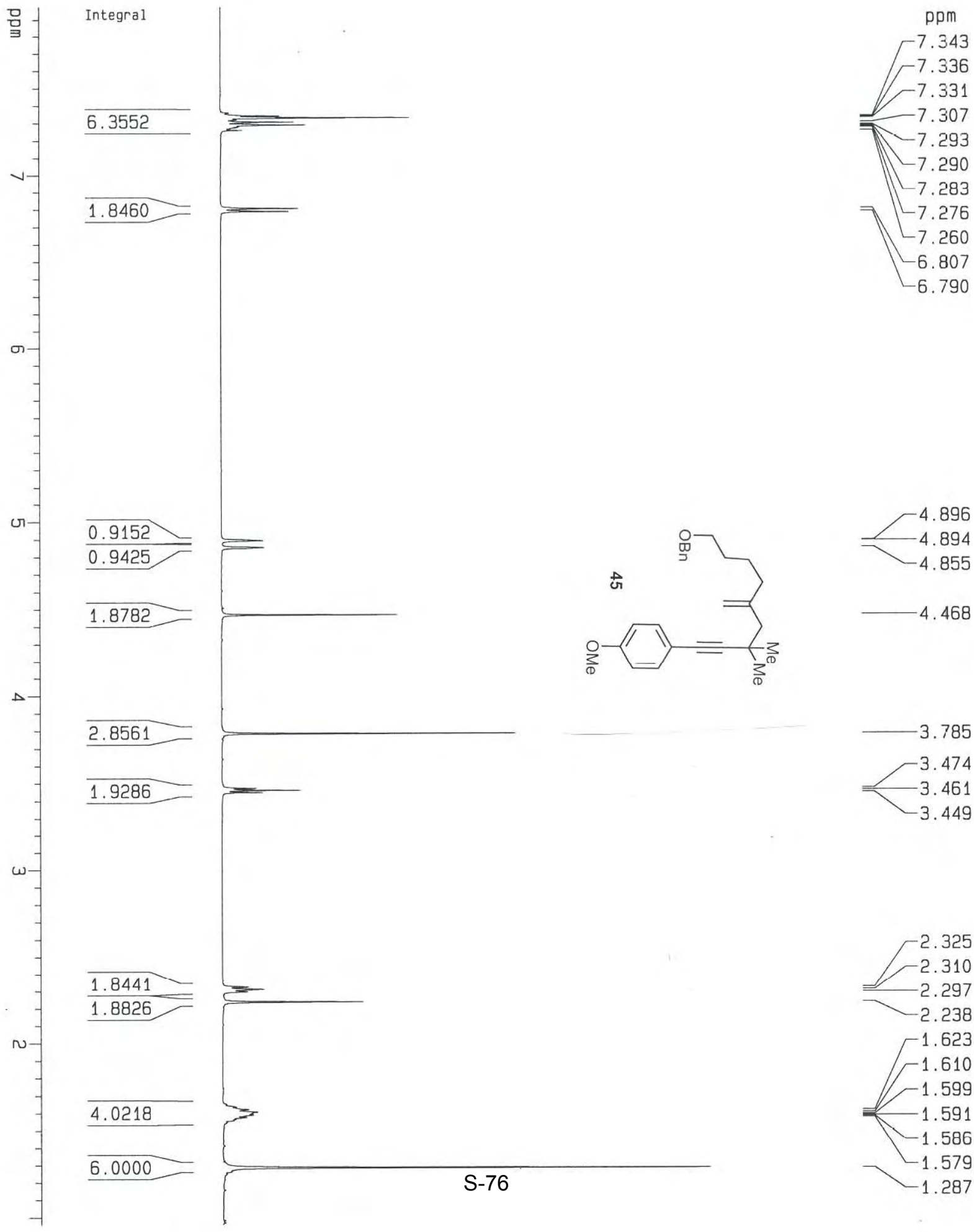

3.785

3.474

3.461

3.449

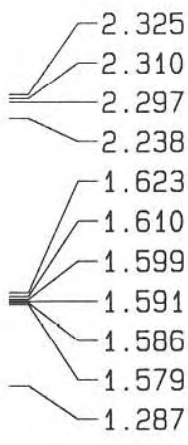




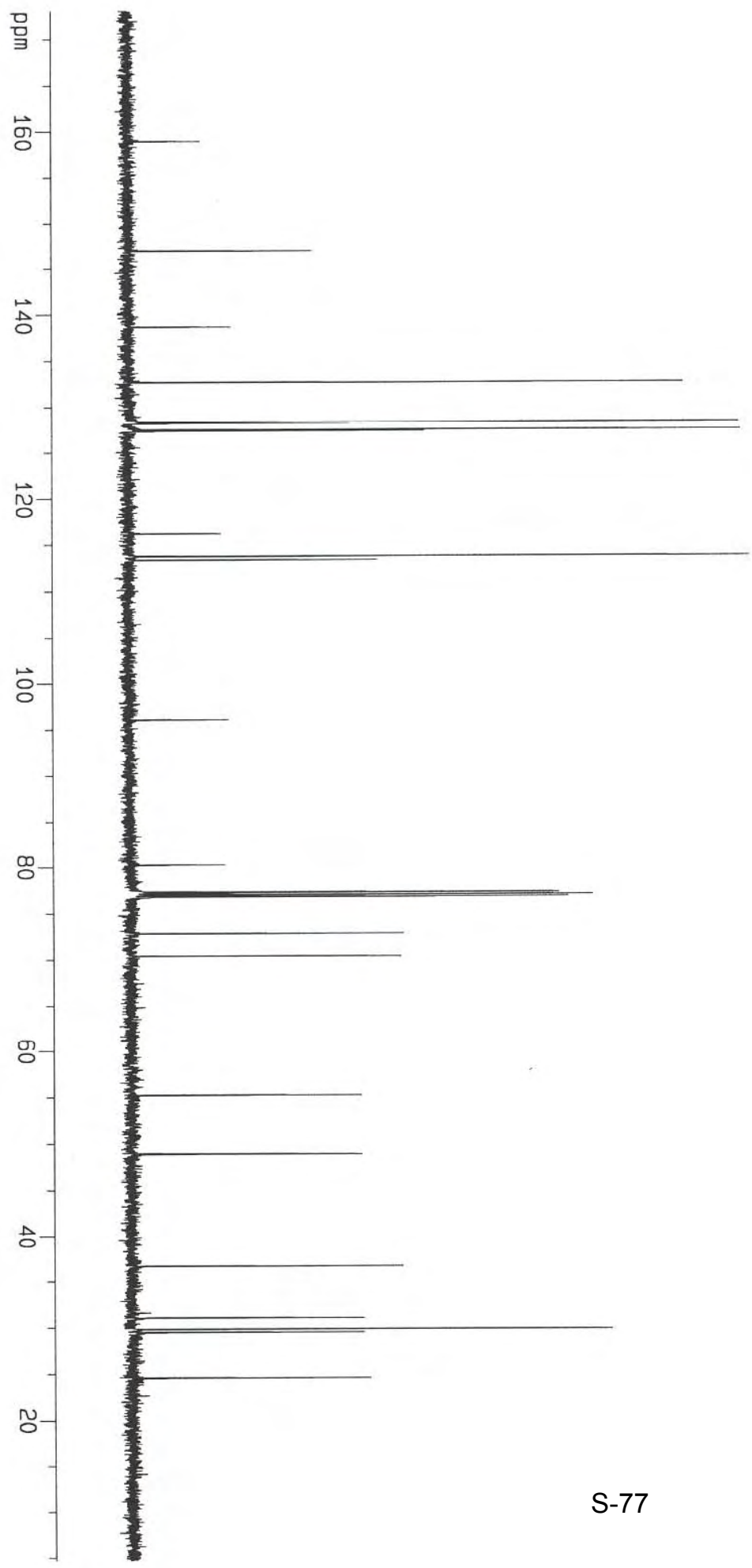

$-158.894$

146.897

138.653

132.652

128. 306

$-127.571$

127.425

$-116.216$

113.724

113.298

96.036

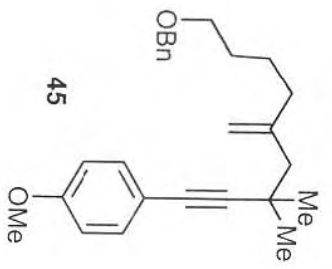

80.212

77.253

76.999

76.744

72.795

70.368

55.201

48.866

36.628

31.010

29.827

29.469

24.537 


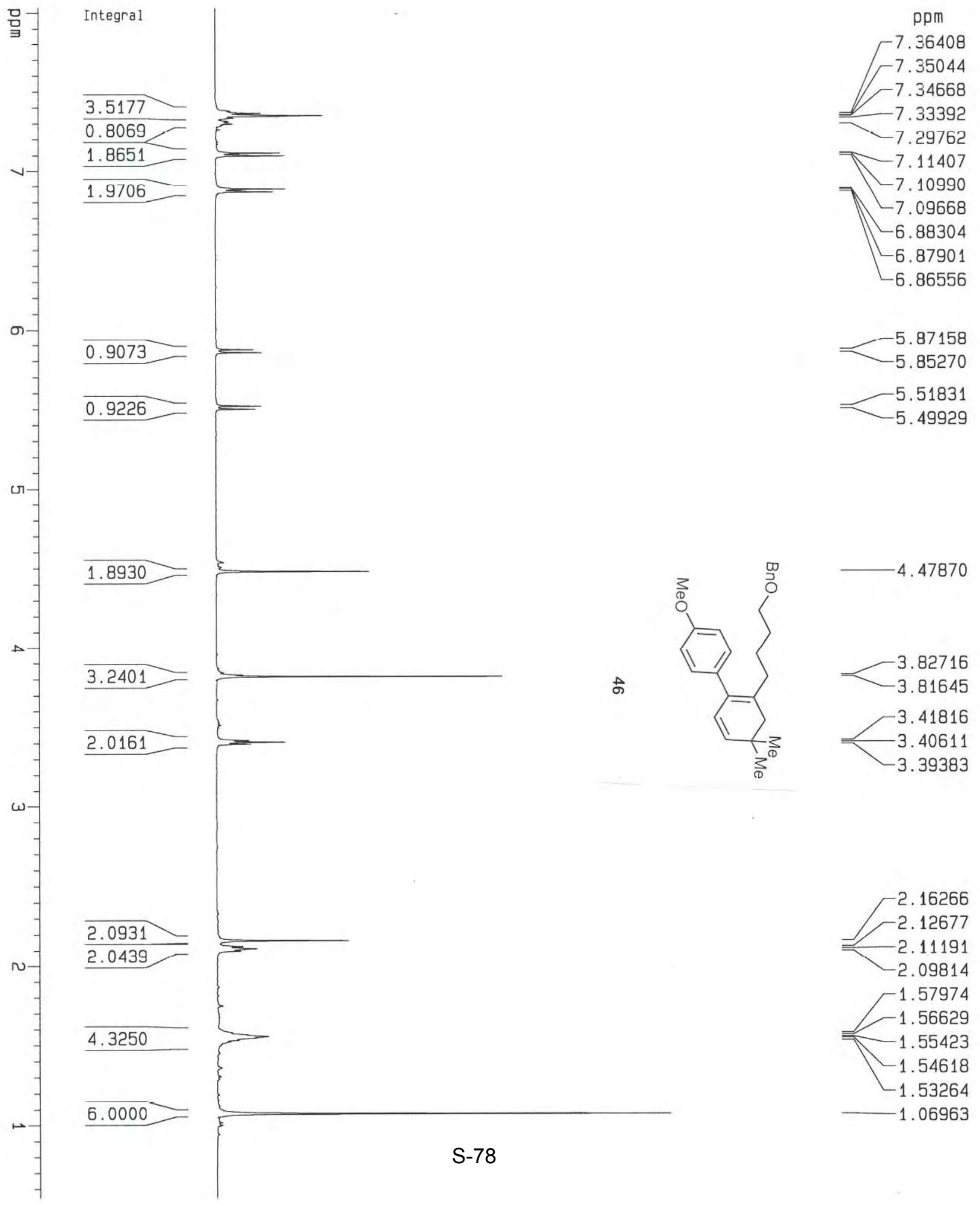



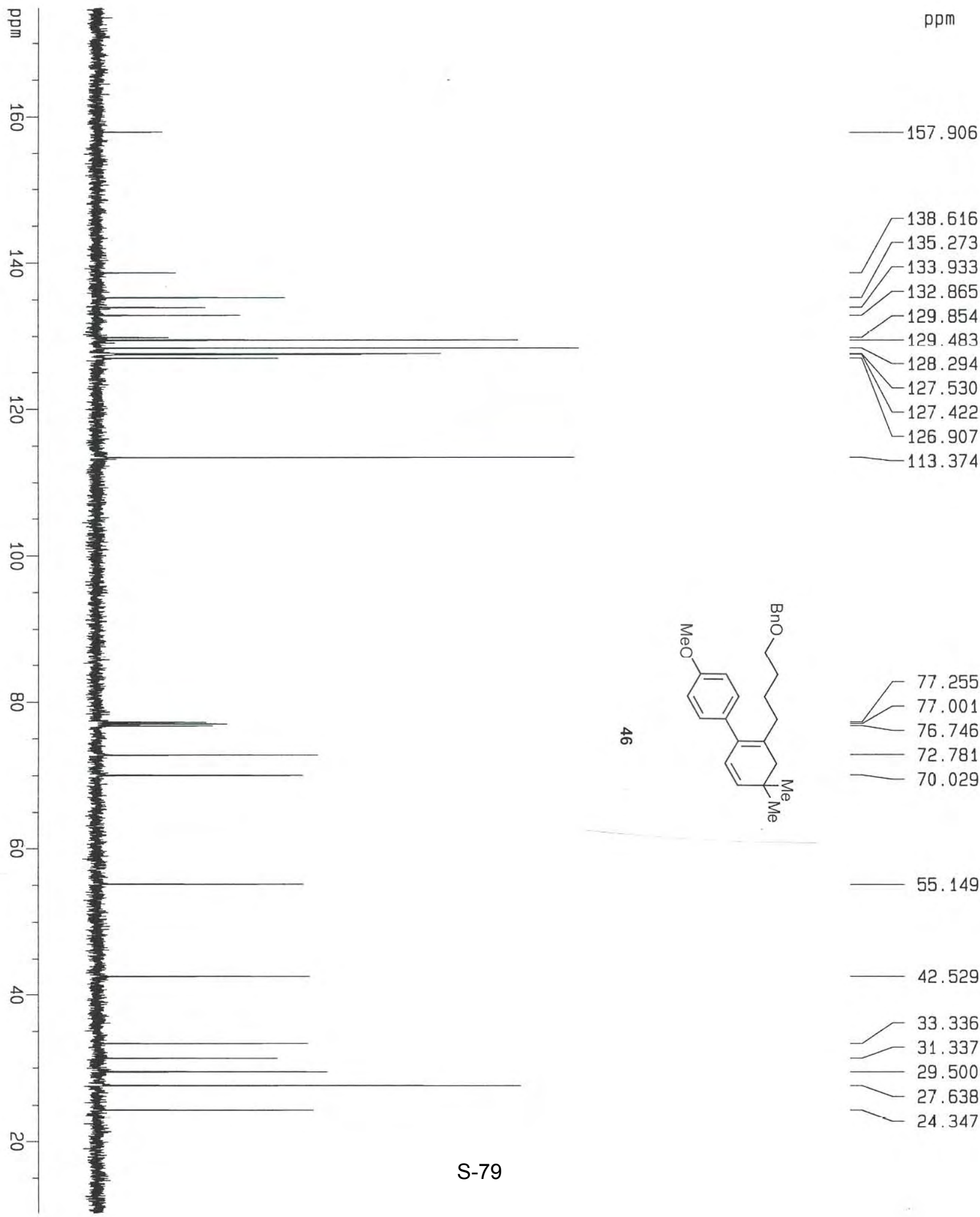
135.273 133.933 $-132.865$ $-129.854$ 129. 483 128.294 $-127.530$ $-127.422$ 126.907 $-113.374$
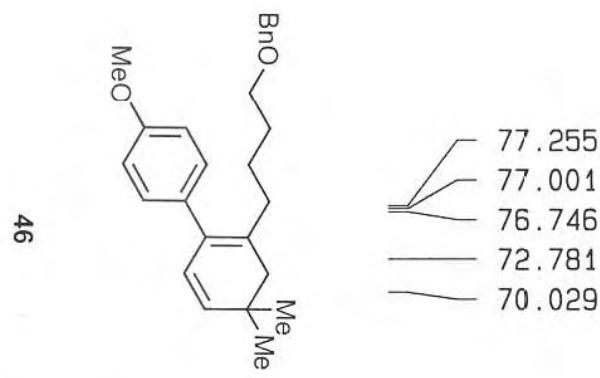

55.149

42.529

33. 336

31.337

29.500

27.638

24.347 


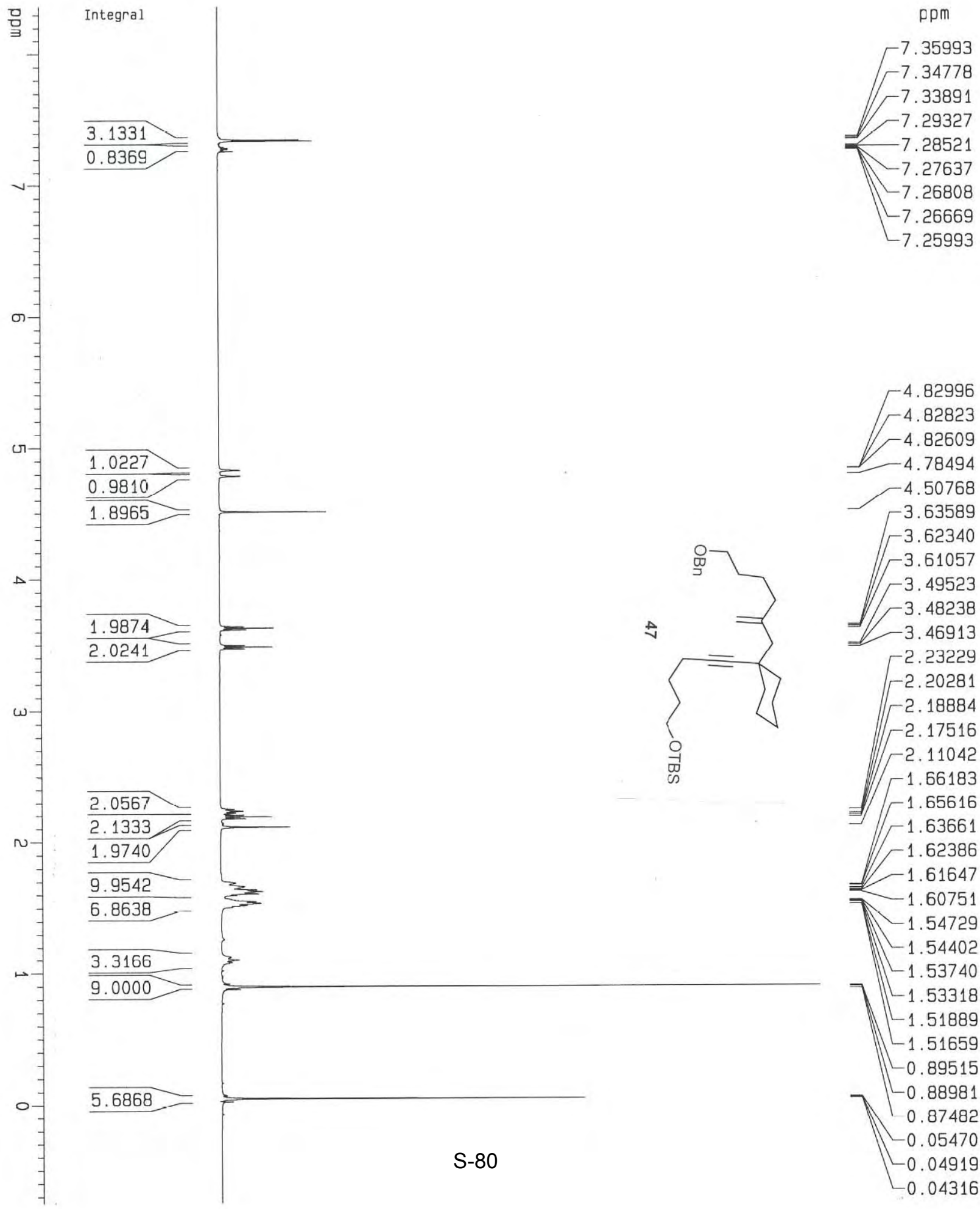




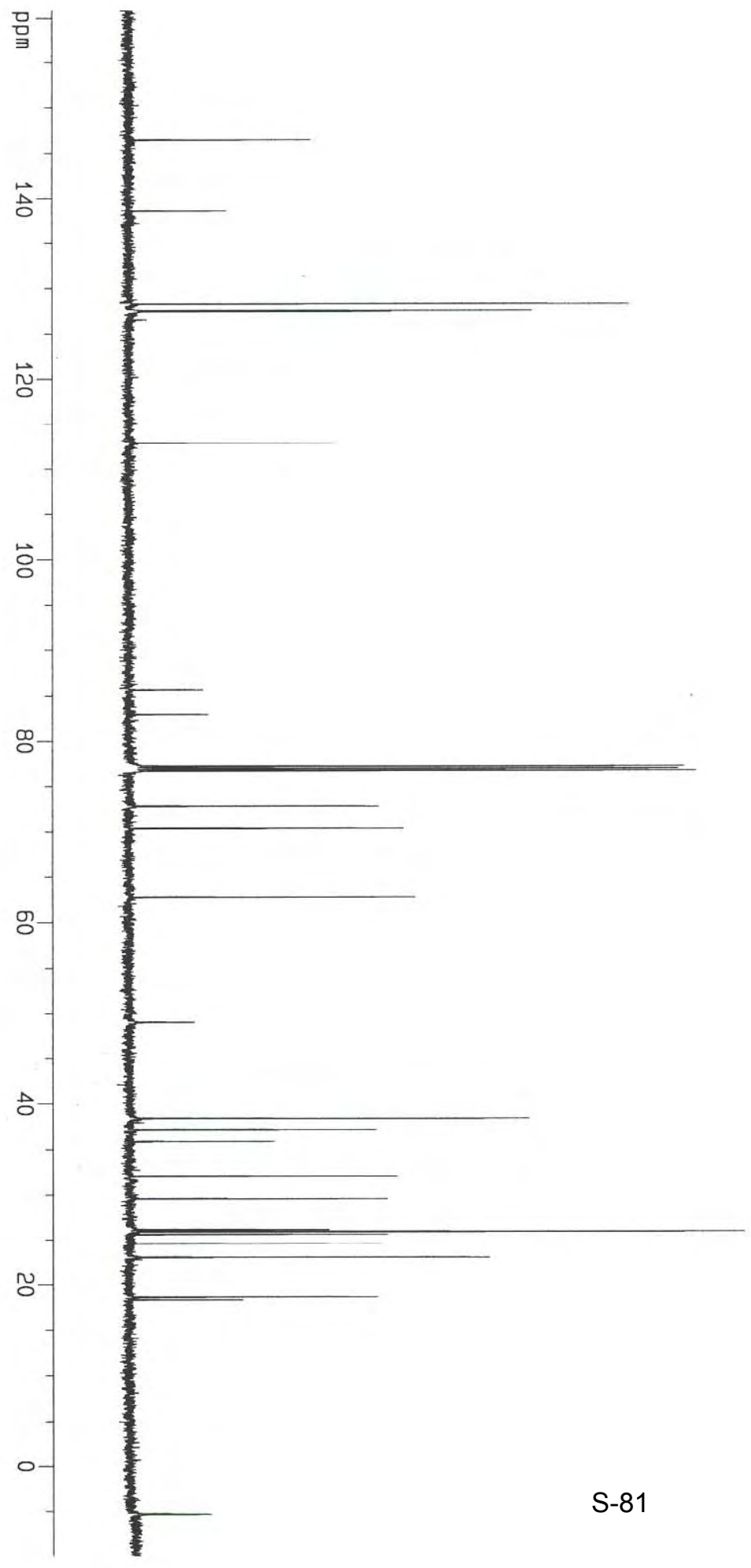

128. 285

127.551

127.408

112.873
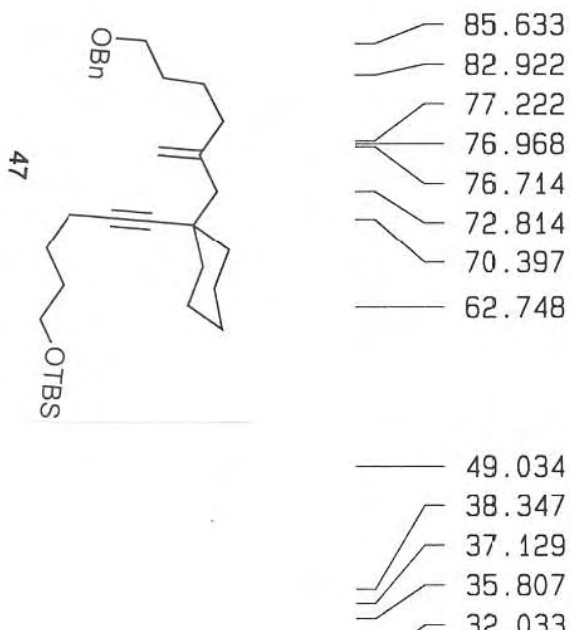

49.034

38.347

37.129

35.807

32.033

29.511

26. 144

25.913

25.598

24.532

22. 970

18. 591

18. 296 


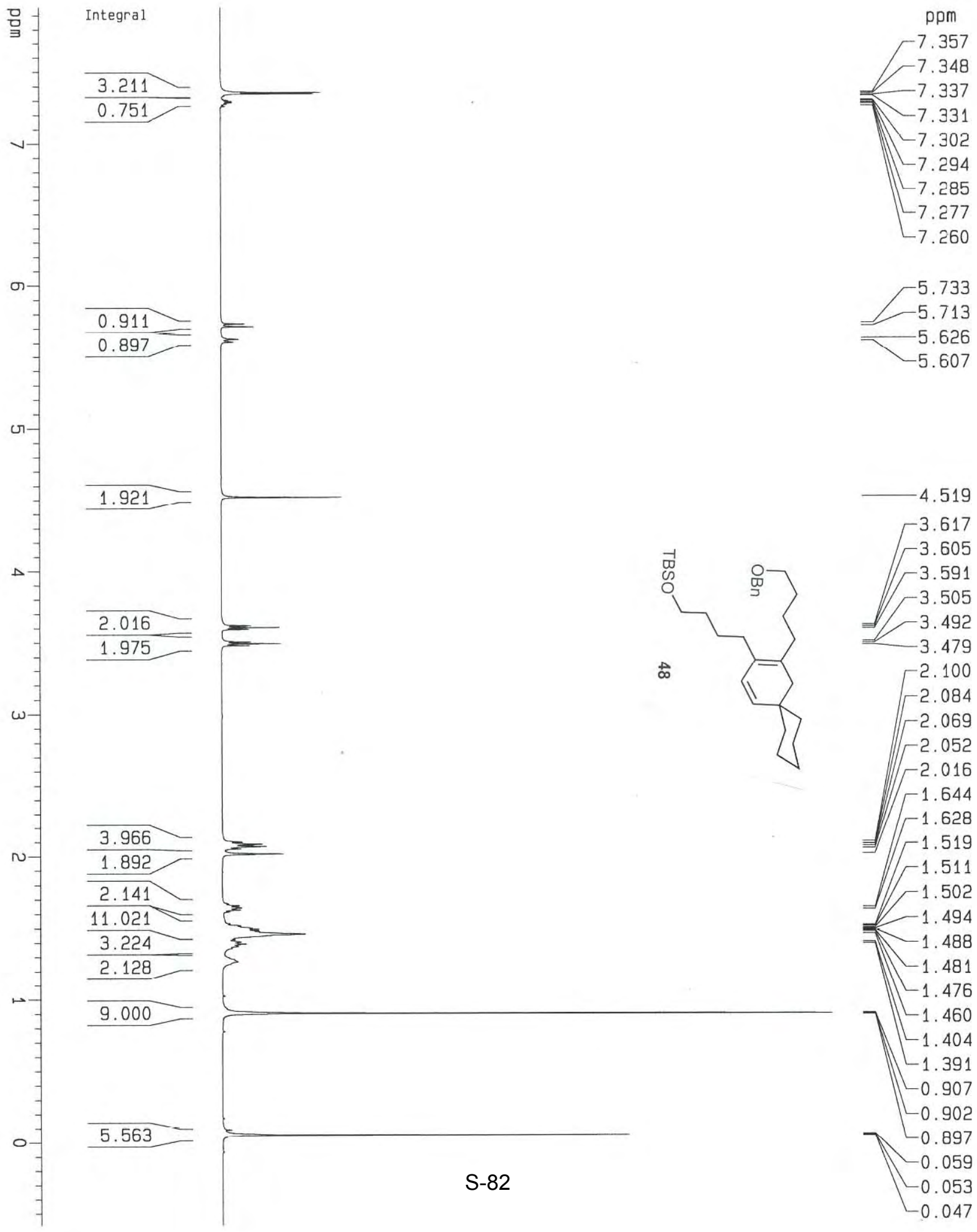



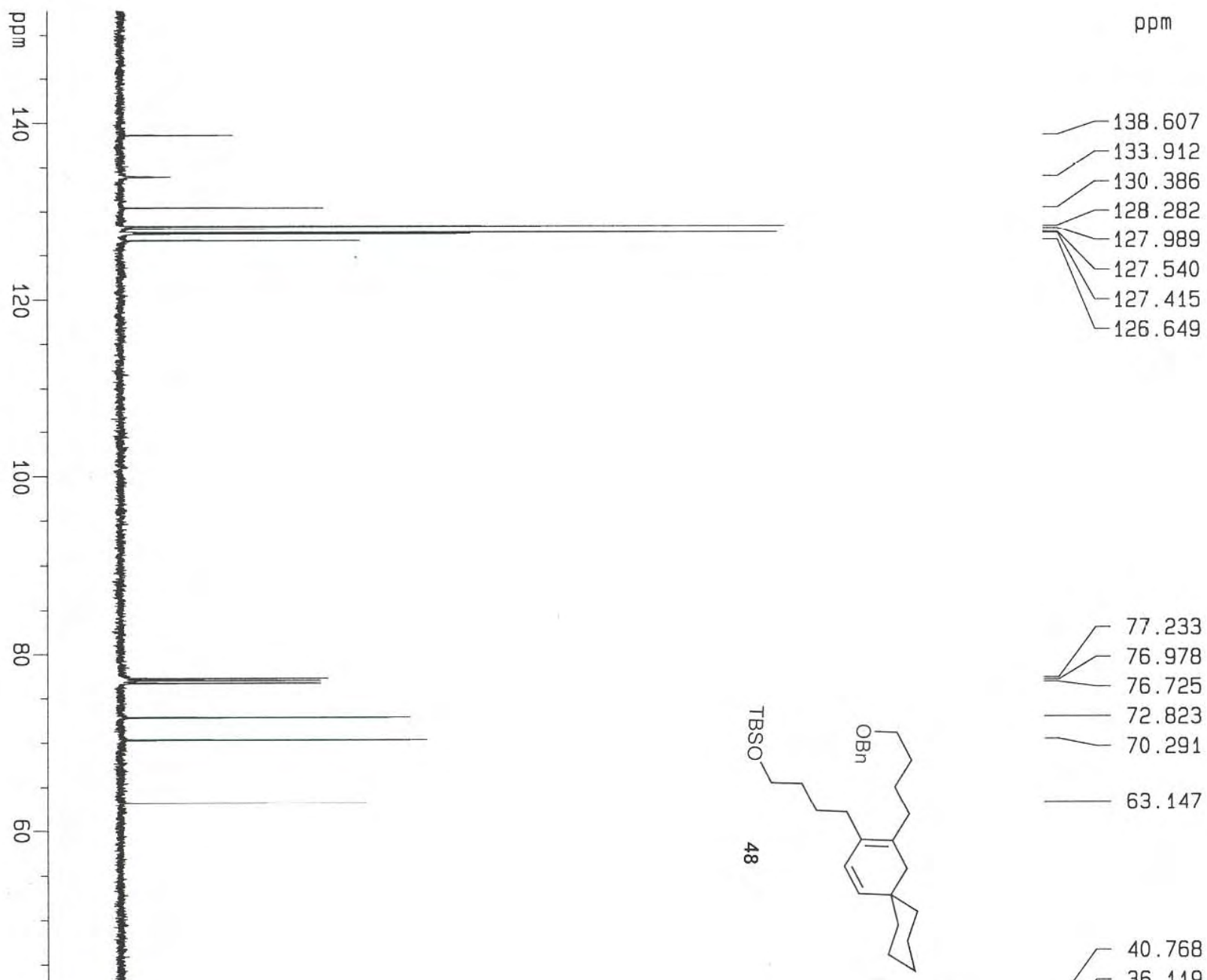


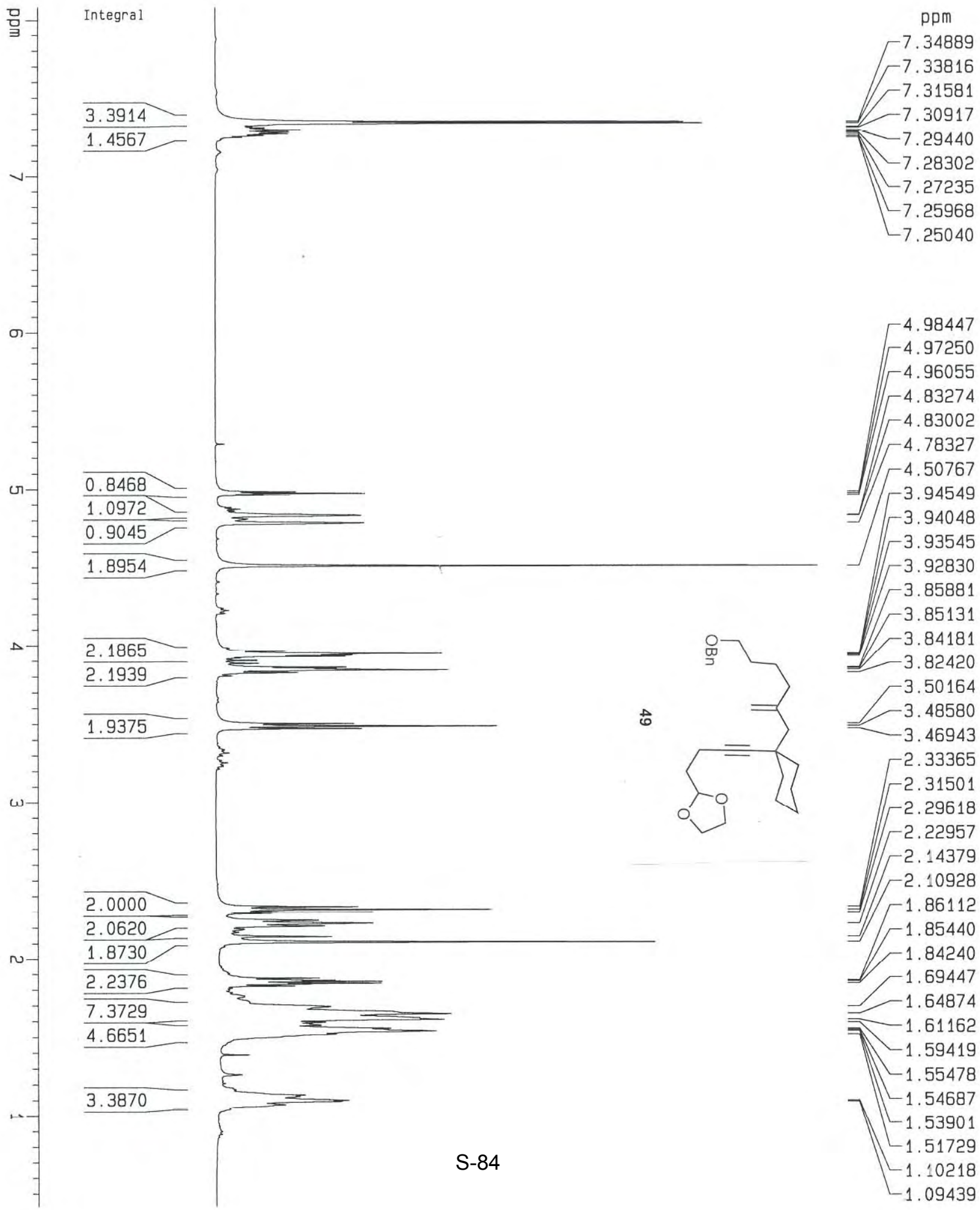



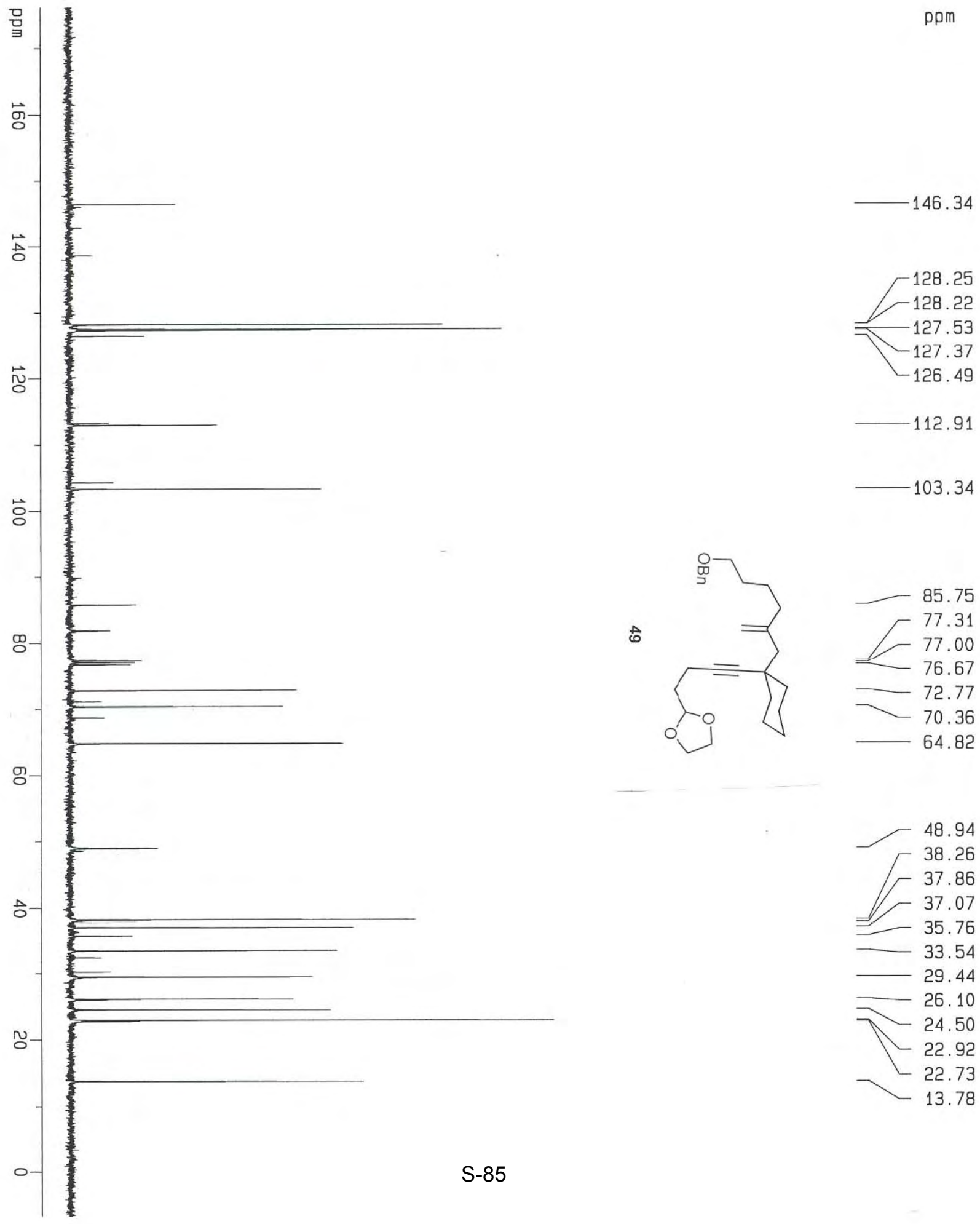

$-112.91$

$-103.34$
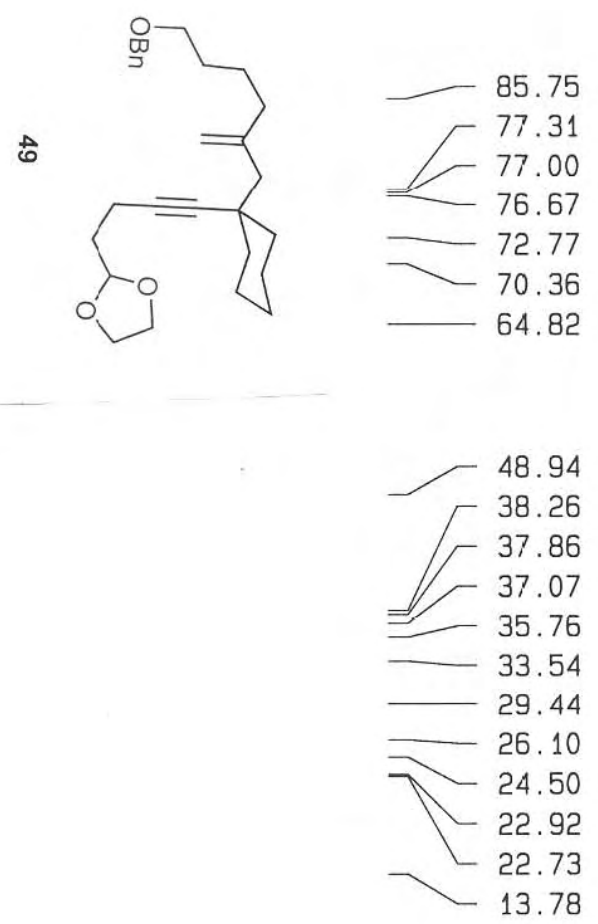


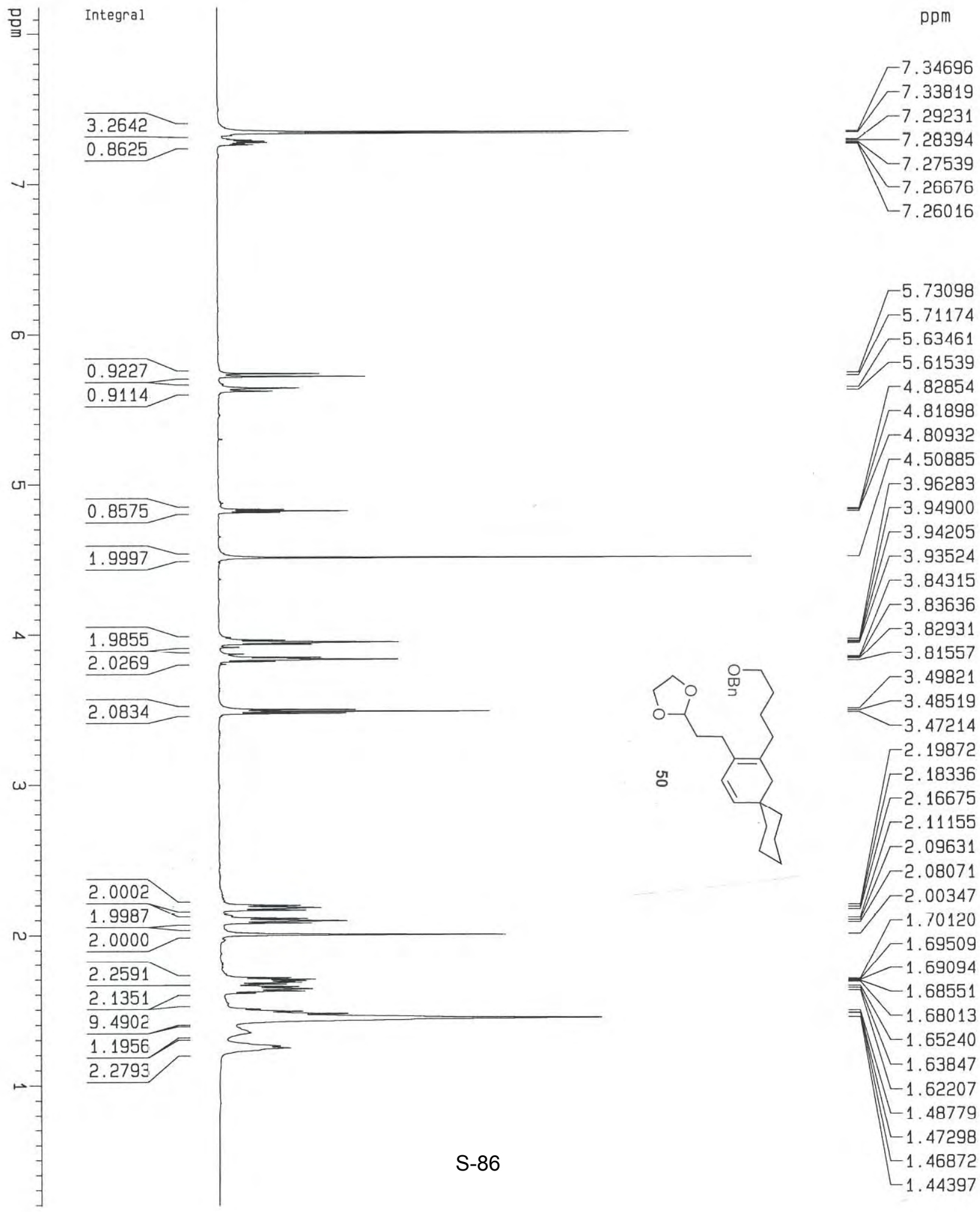



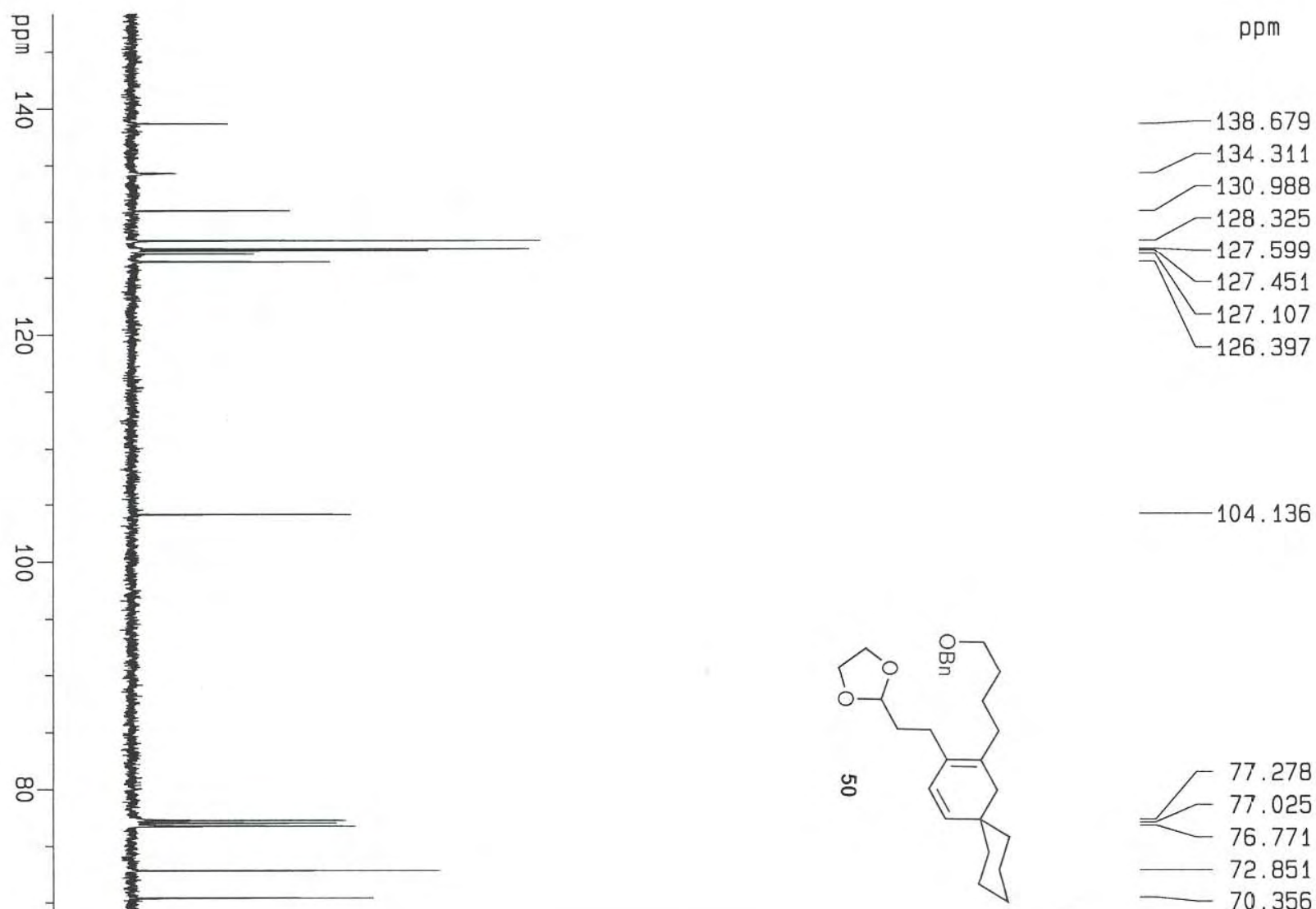

客

ø

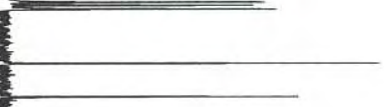

8

บ 


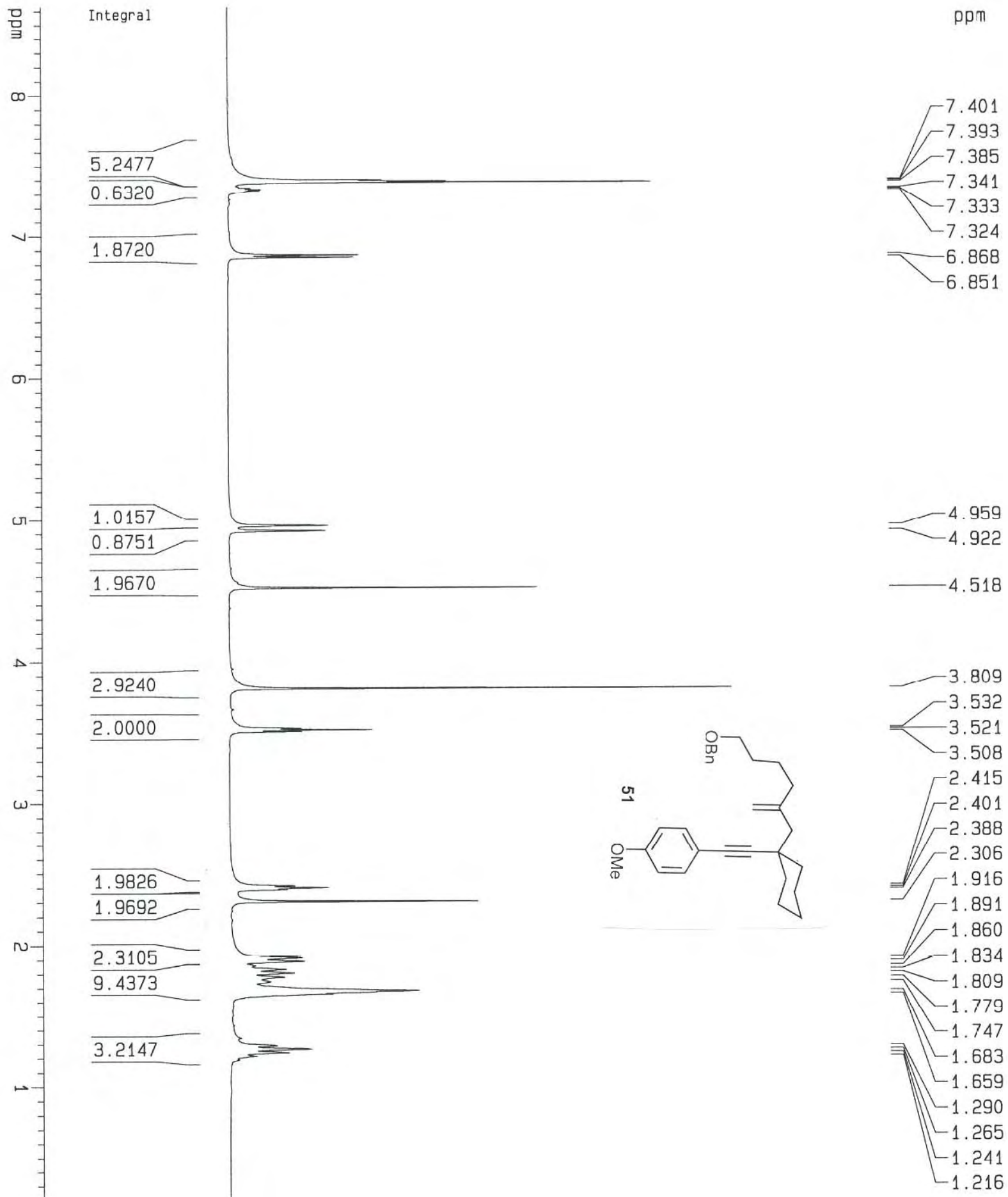



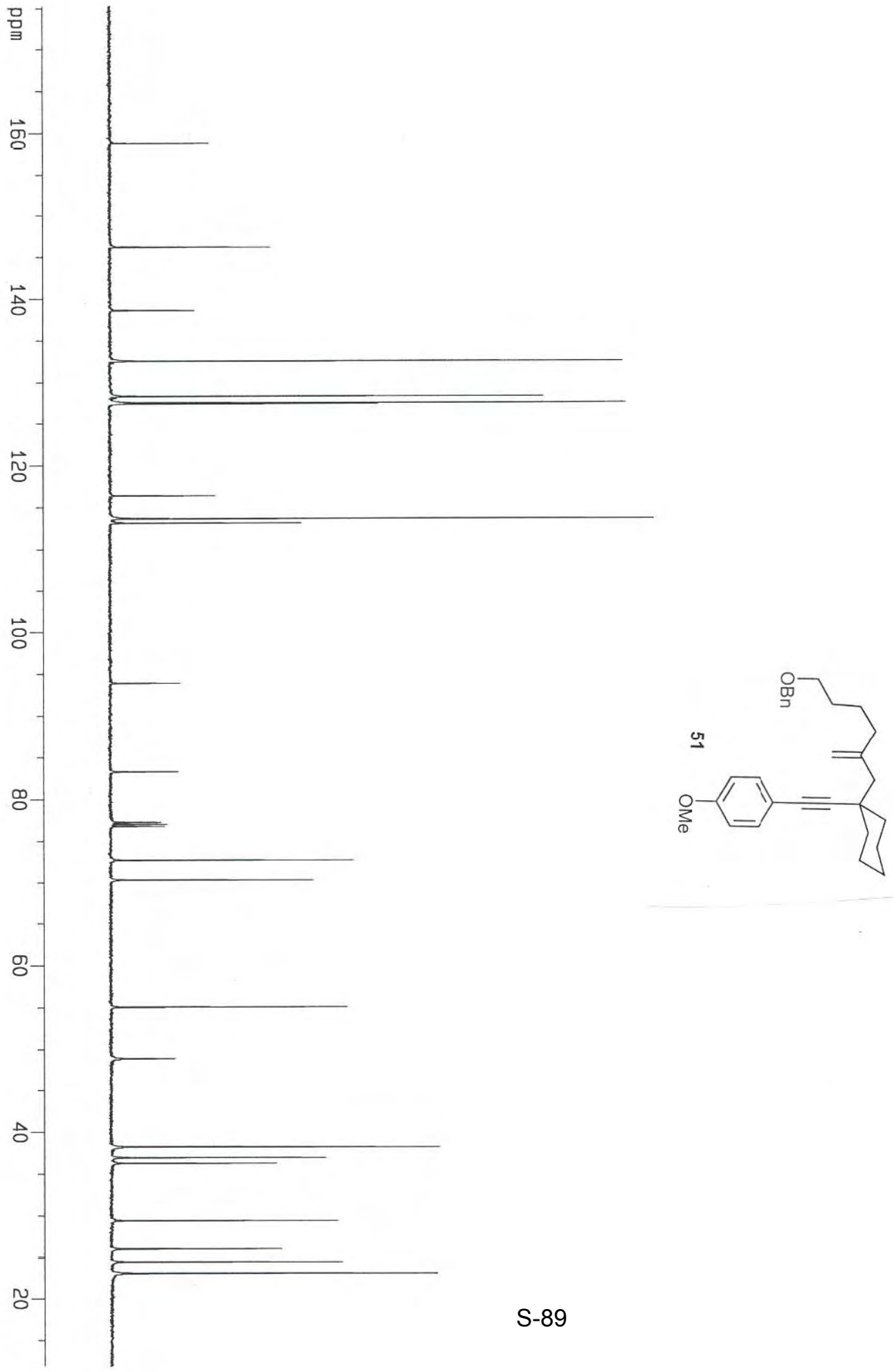

93.881

83. 268 77.253 76.999 76.744 72.677 70.282

55.041 48.889

38.200 36.939 36.232 29. 421 26.085 24.488 23.022

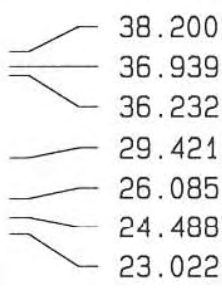




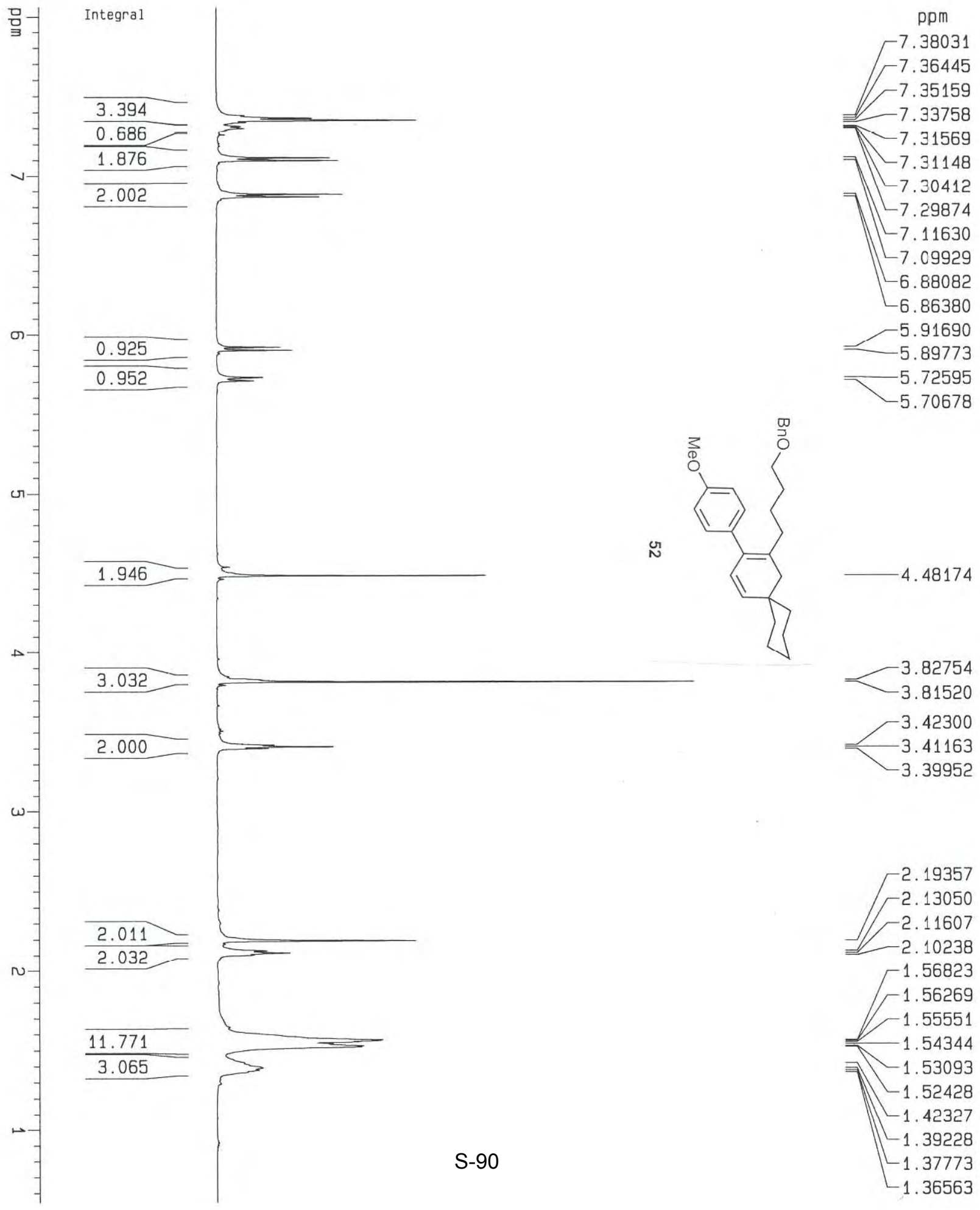



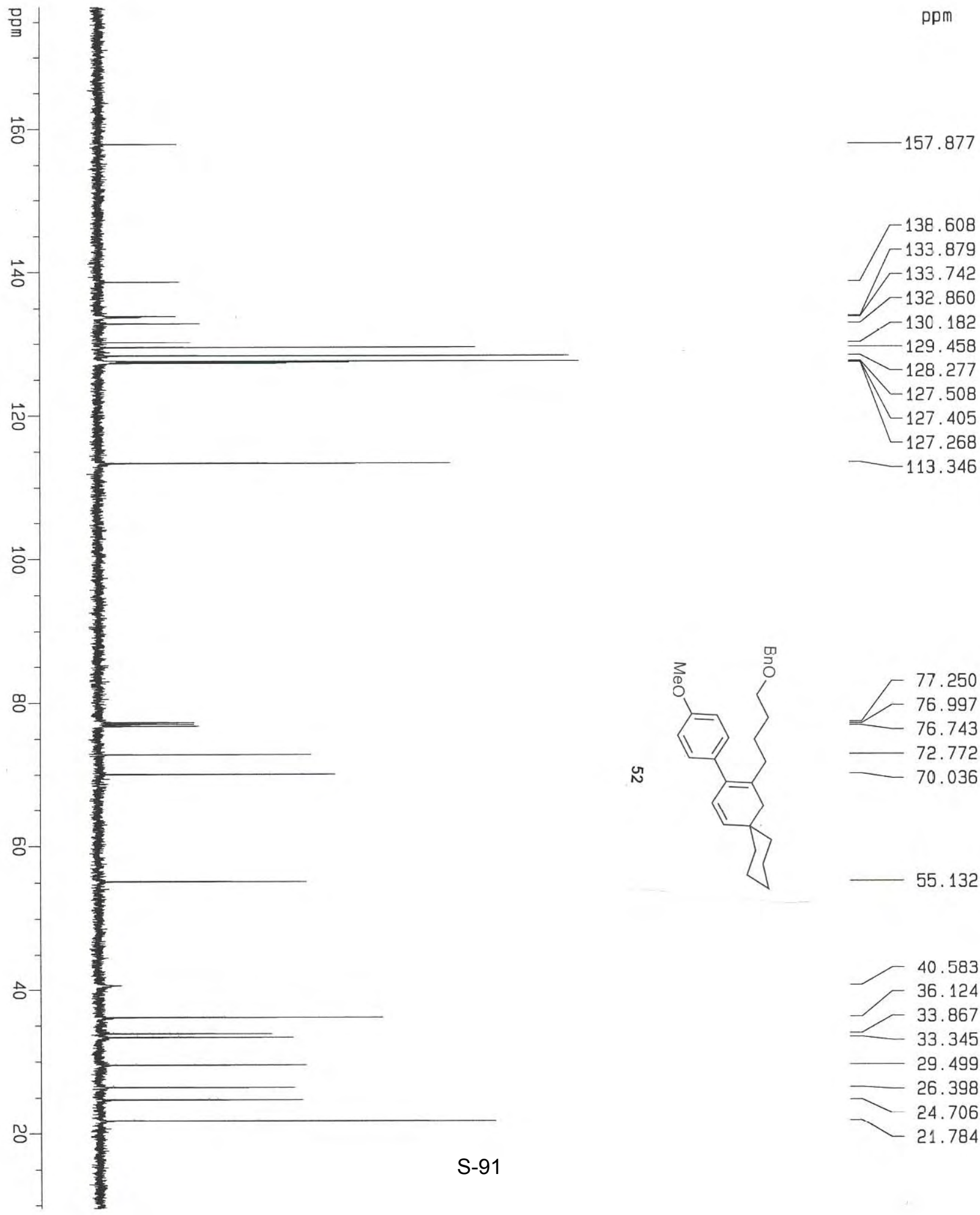

$-157.877$ 


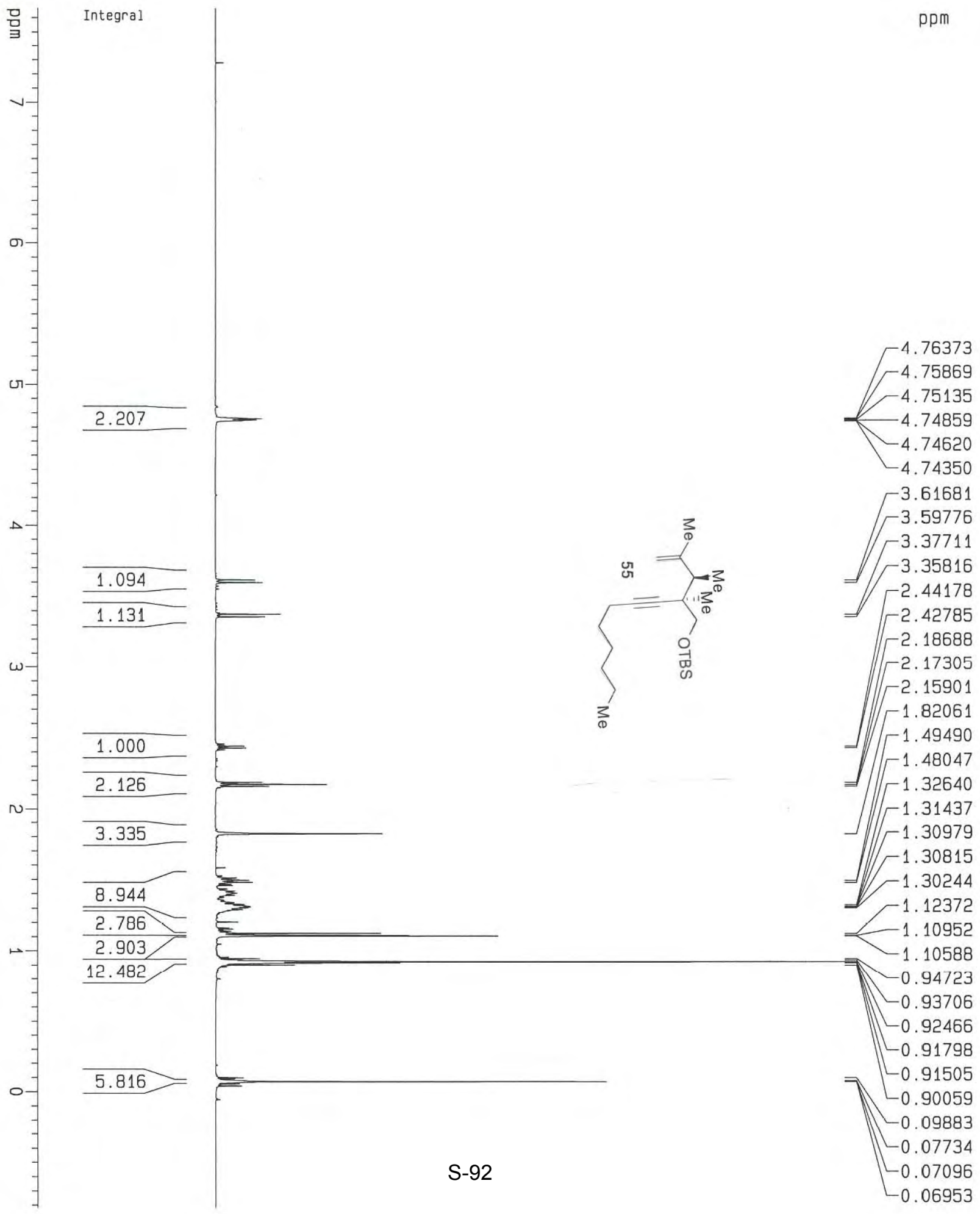




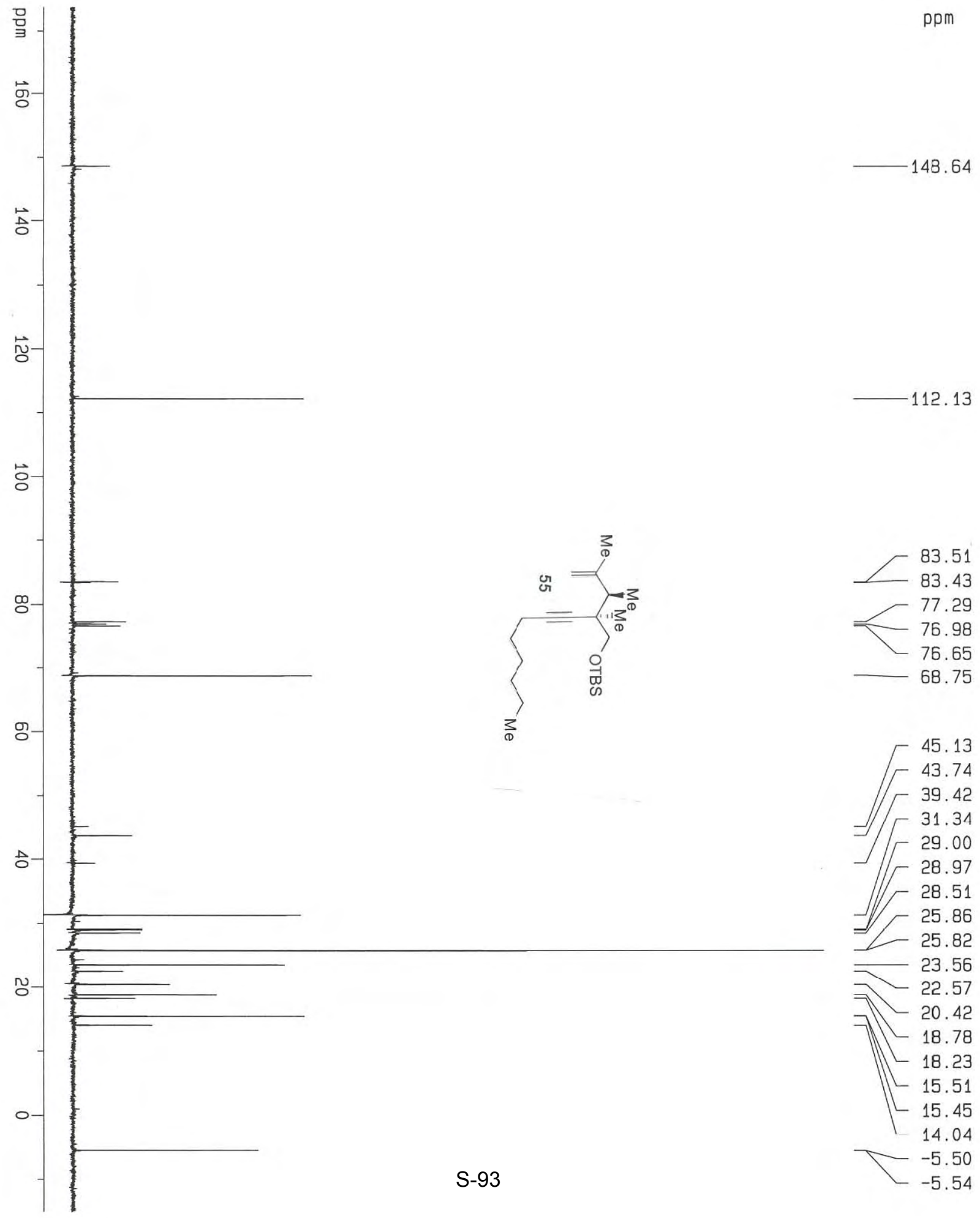




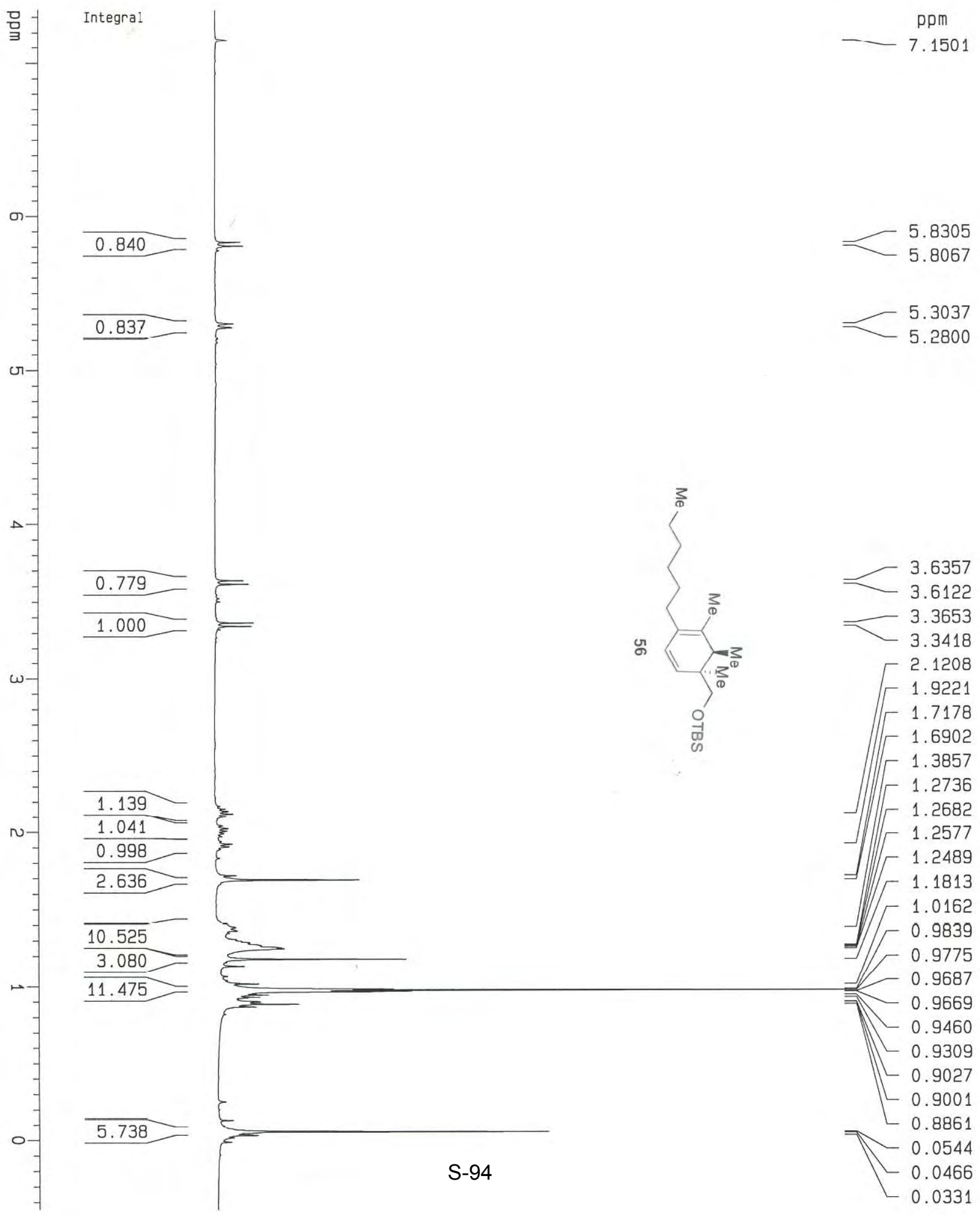




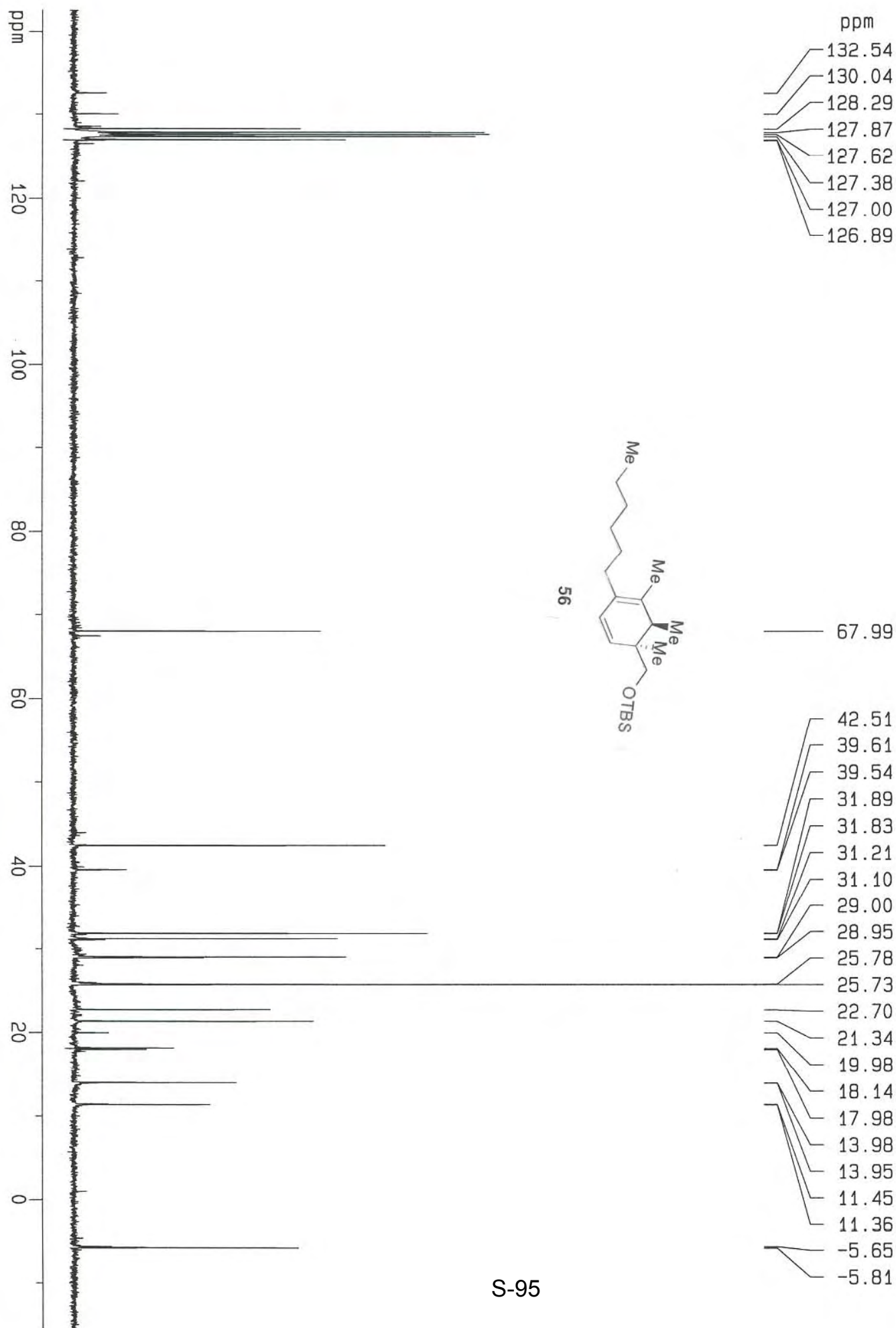



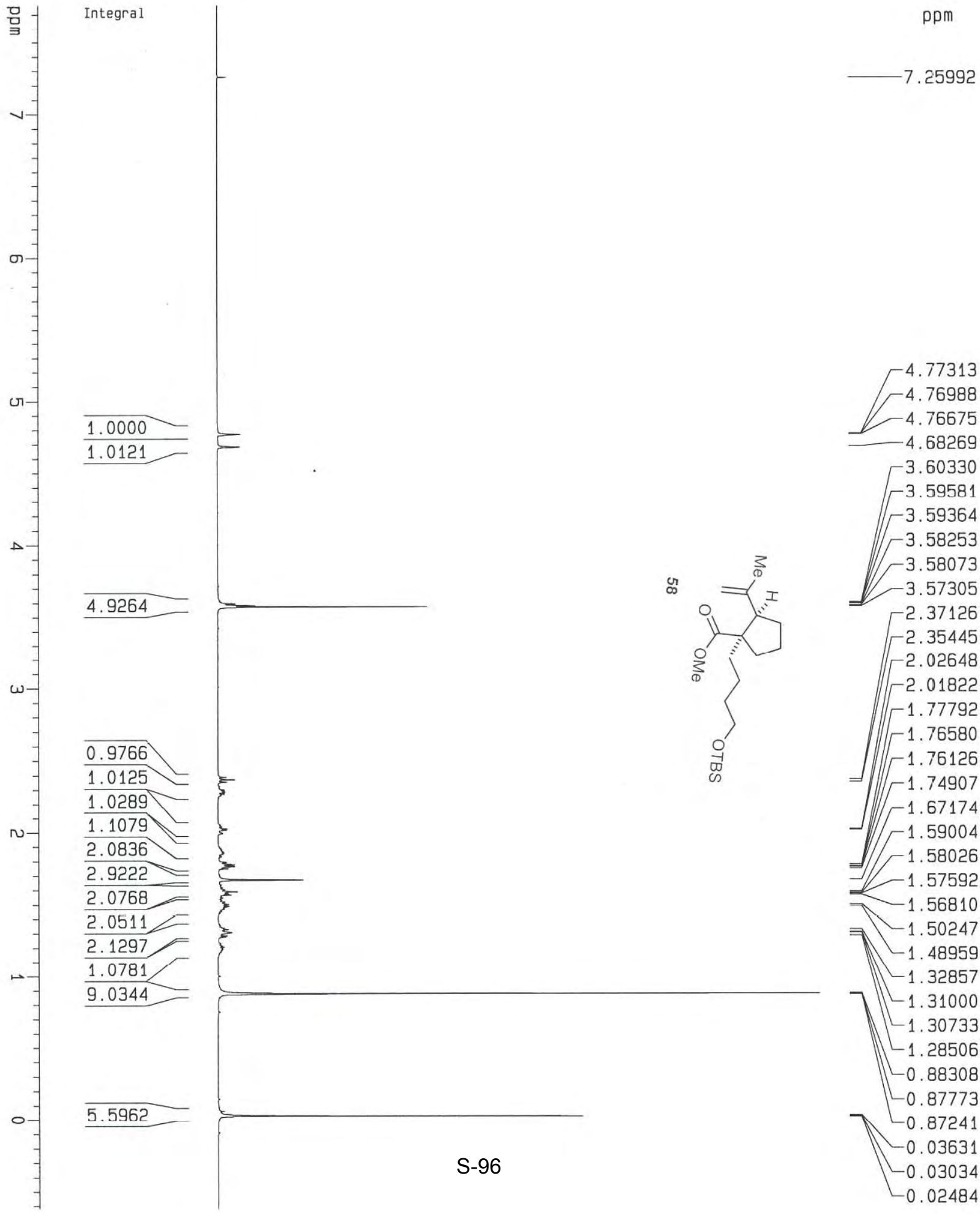

$-3.60330$

$-3.59581$

$-3.59364$

$-3.58253$

$-3.58073$

$-3.57305$

$-2.37126$

$-2.35445$

$-2.02648$

$-2.01822$

$-1.77792$

$-1.76580$

$-1.76126$

$-1.74907$

$-1.67174$

1.59004

$-1.58026$

$-1.57592$

1.56810

$-1.50247$

$-1.48959$

$-1.32857$

1. 31000

$-1.30733$

$-1.28506$

$-0.88308$

$-0.87773$

$-0.87241$

$-0.03631$

$-0.03034$

$-0.02484$ 

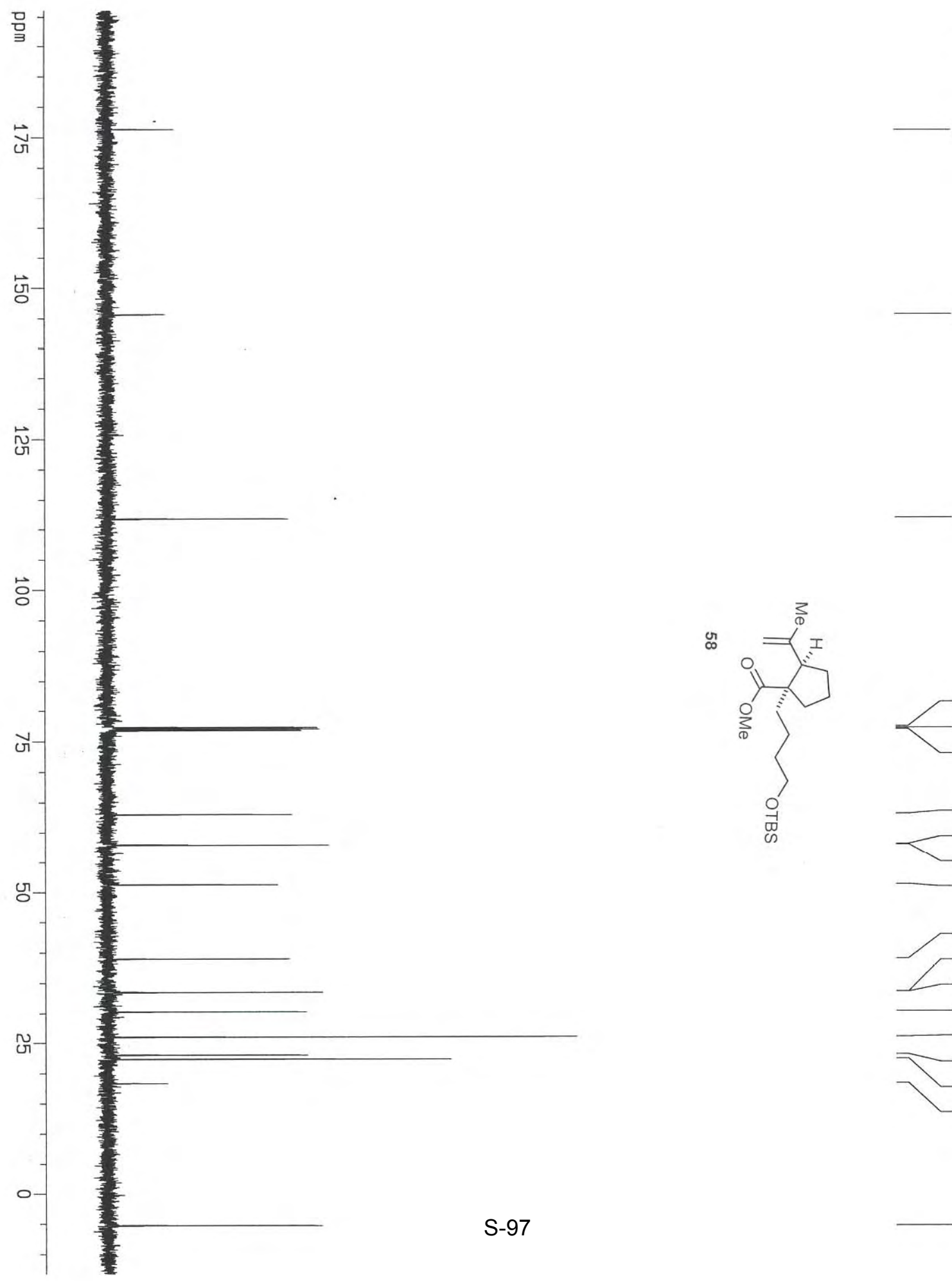

77.258

77.004 76.750

62.946

57.949

57.871

51.163

38.877 33. 476

33. 399

30. 228

25. 927

23. 018

22. 333

18. 301 


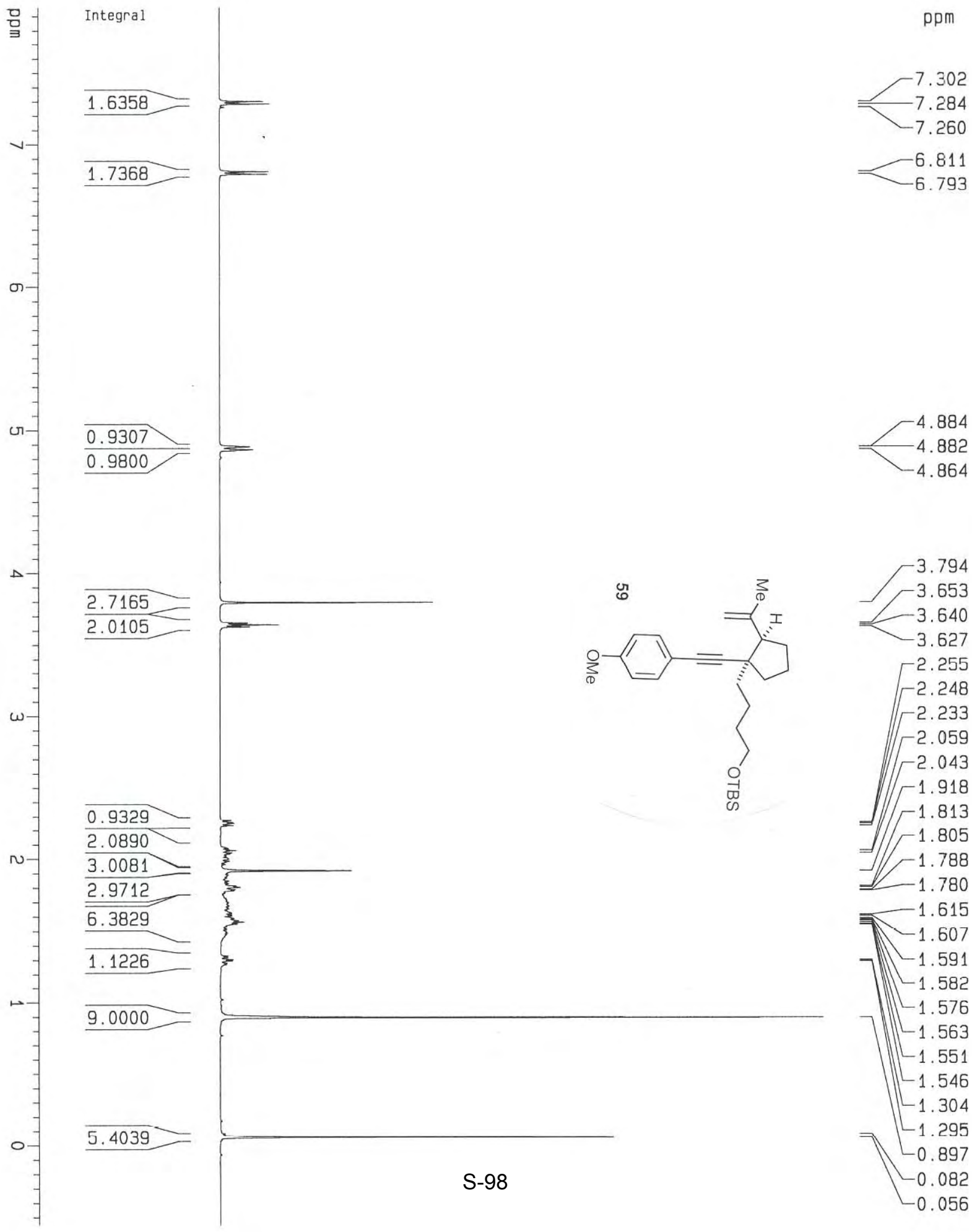




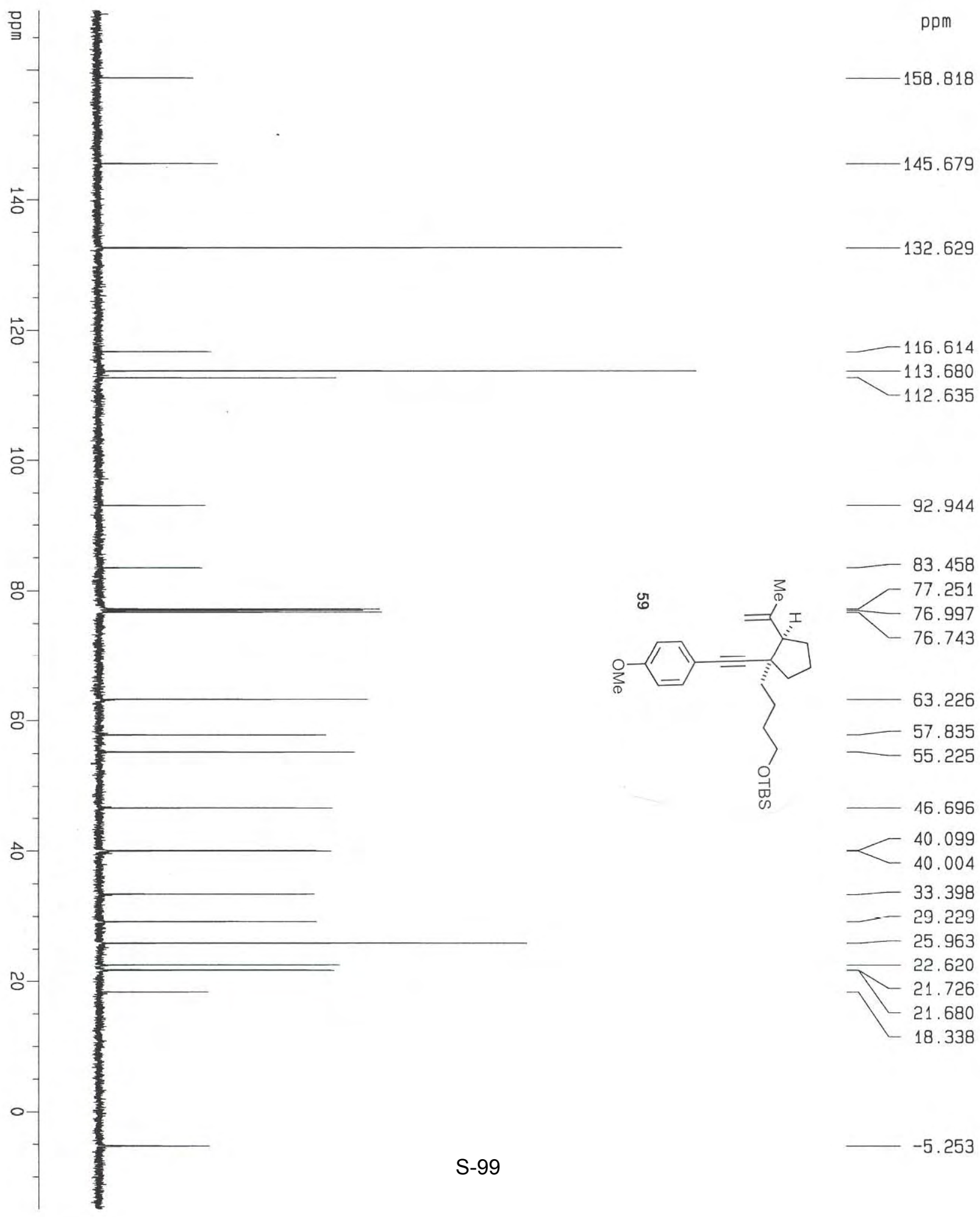



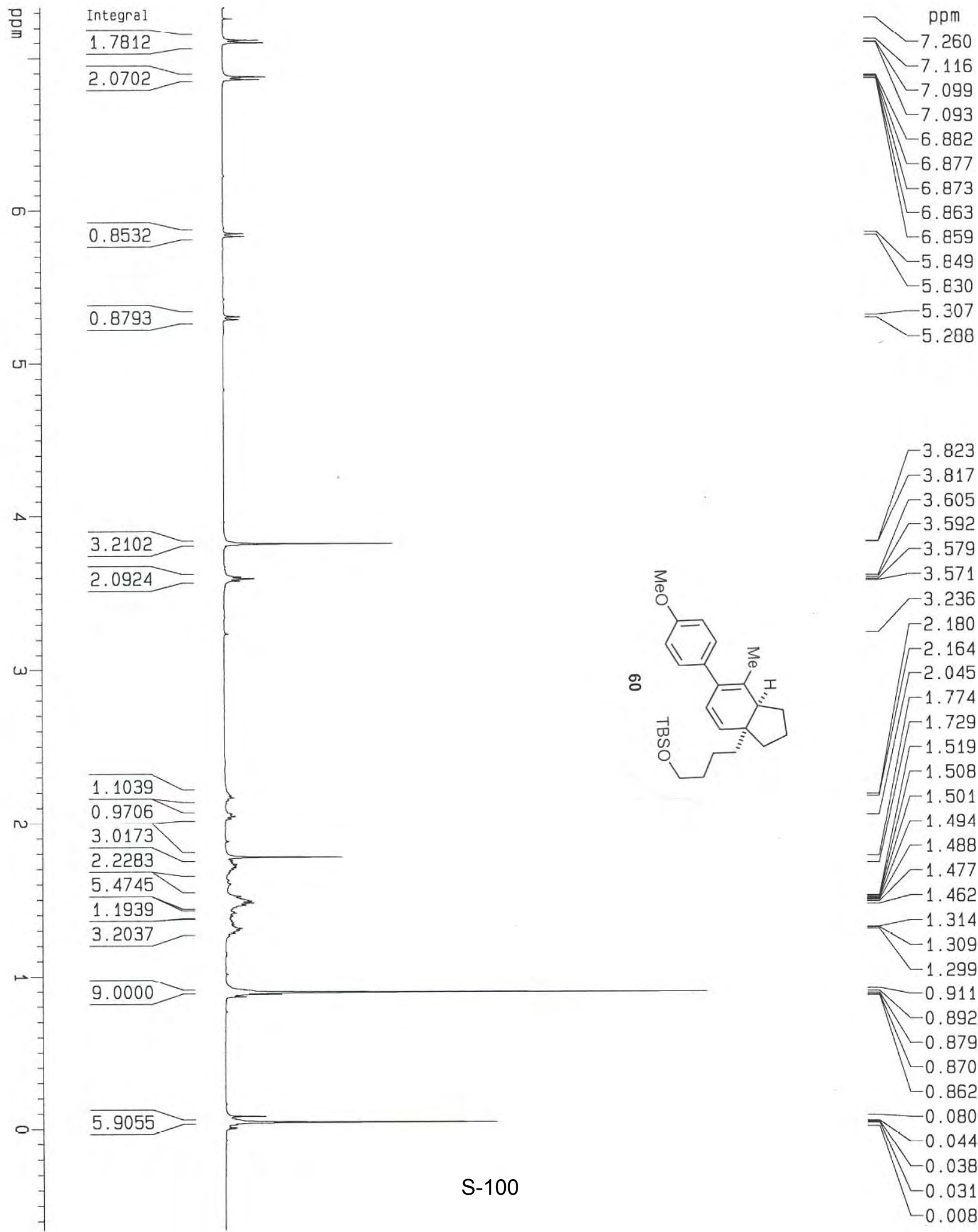

3.823

$-3.817$

$-3.605$

$-3.592$

$-3.579$

$-3.571$

$-3.236$

$-2.180$

$-2.164$

$-2.045$

$-1.774$

$-1.729$

$-1.519$

-1.508

$=-1.501$

-1.494

$-1.488$

$-1.477$

$-1.462$

$-1.314$

1.309

$-1.299$

$-0.911$

$-0.892$

$-0.879$

$-0.870$

$-0.862$

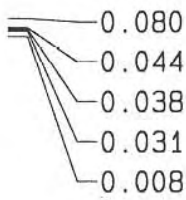



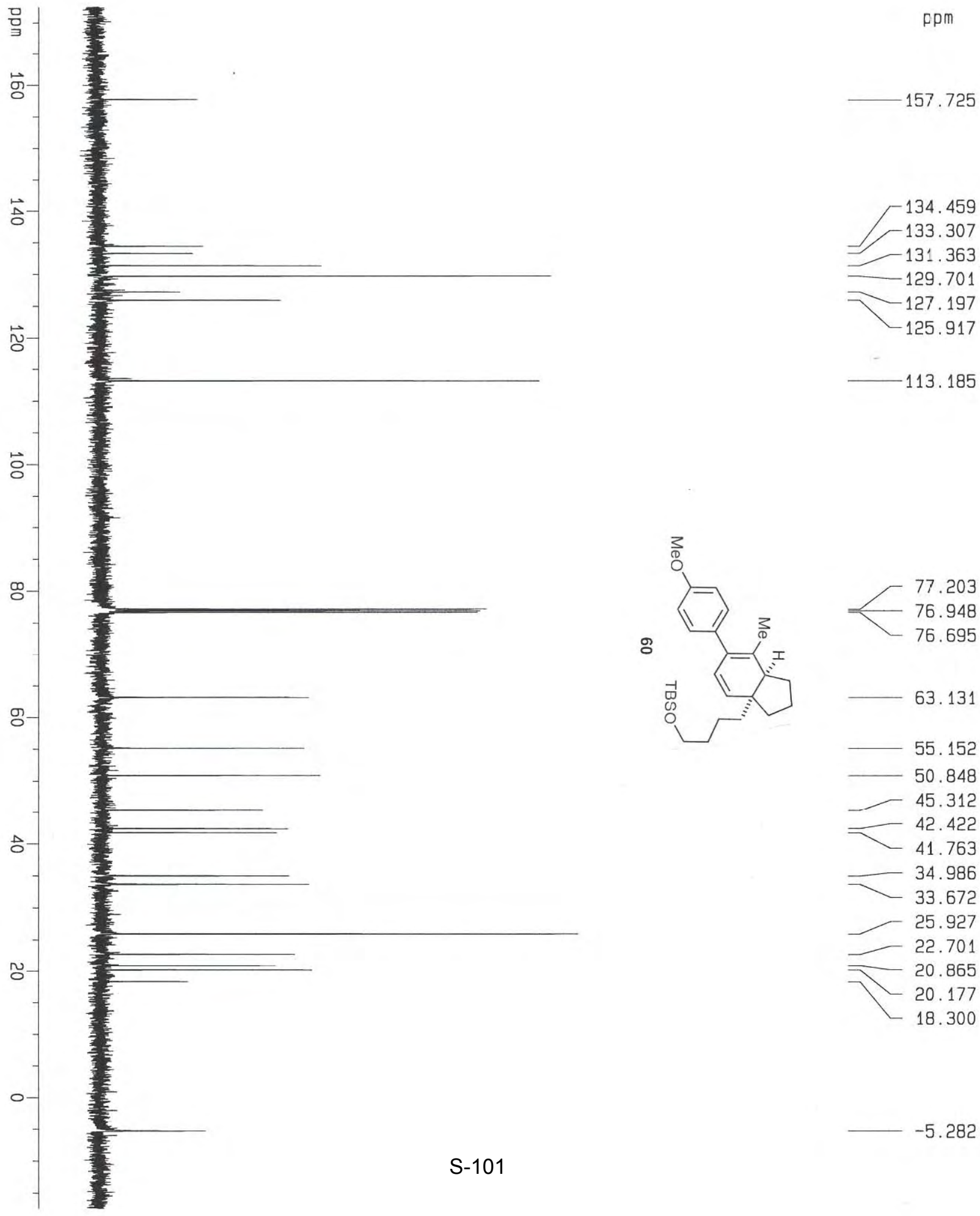


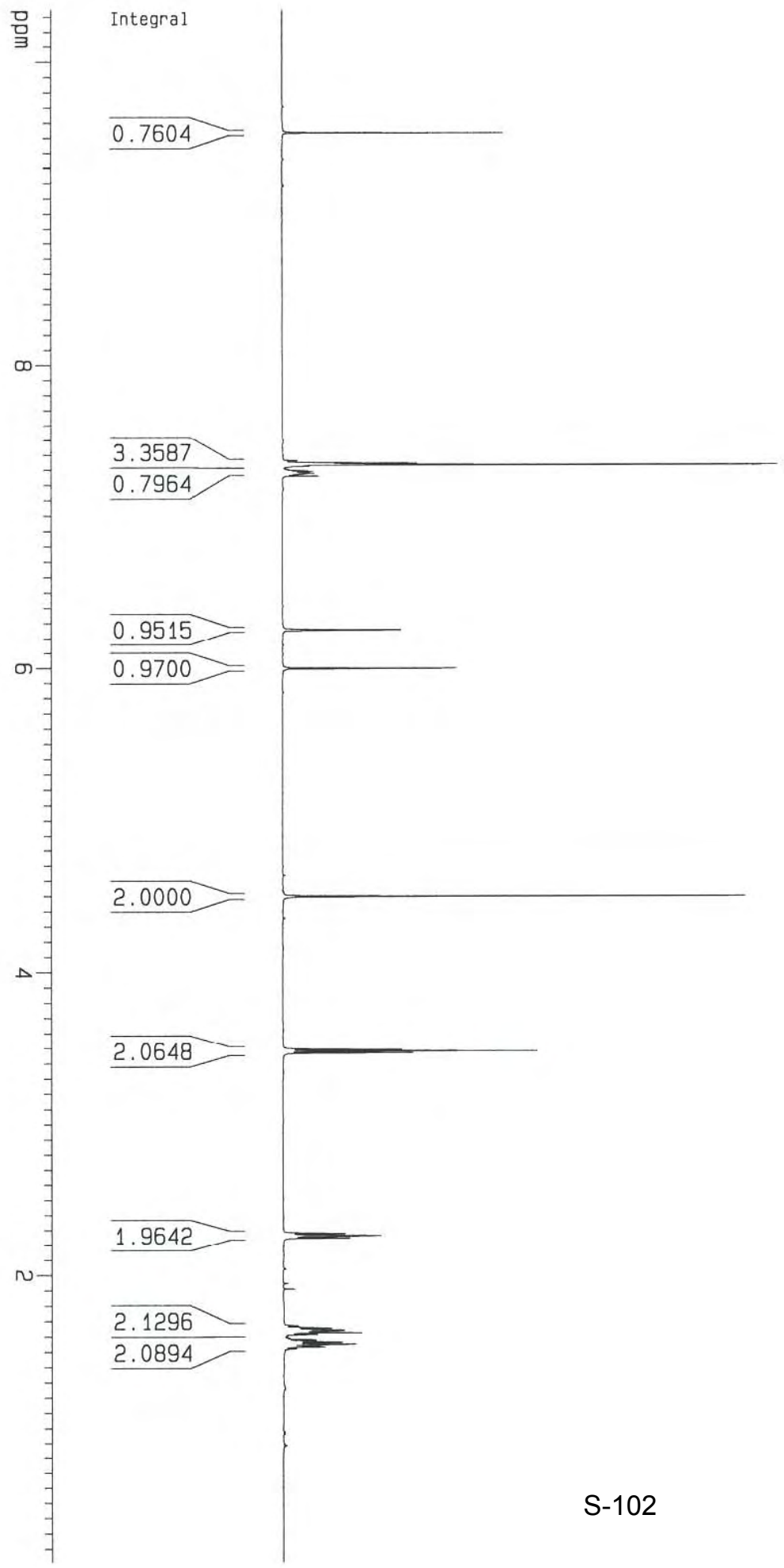




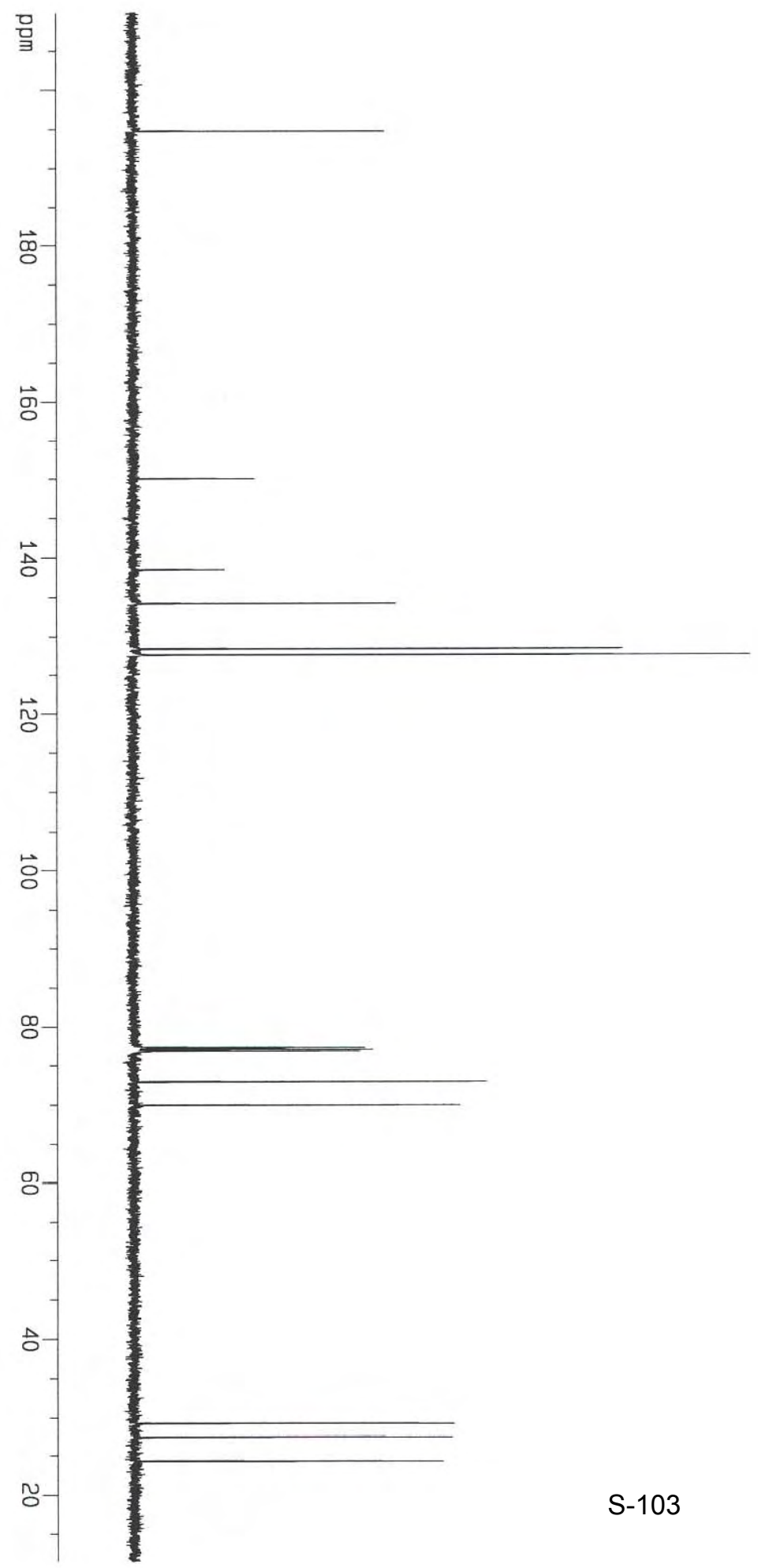

149. 992

$-138.491$

134.192

128.319

$-127.586$

$-127.482$

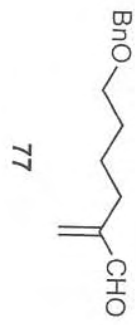

77.255

77.000

76.747

72.874

69.940 


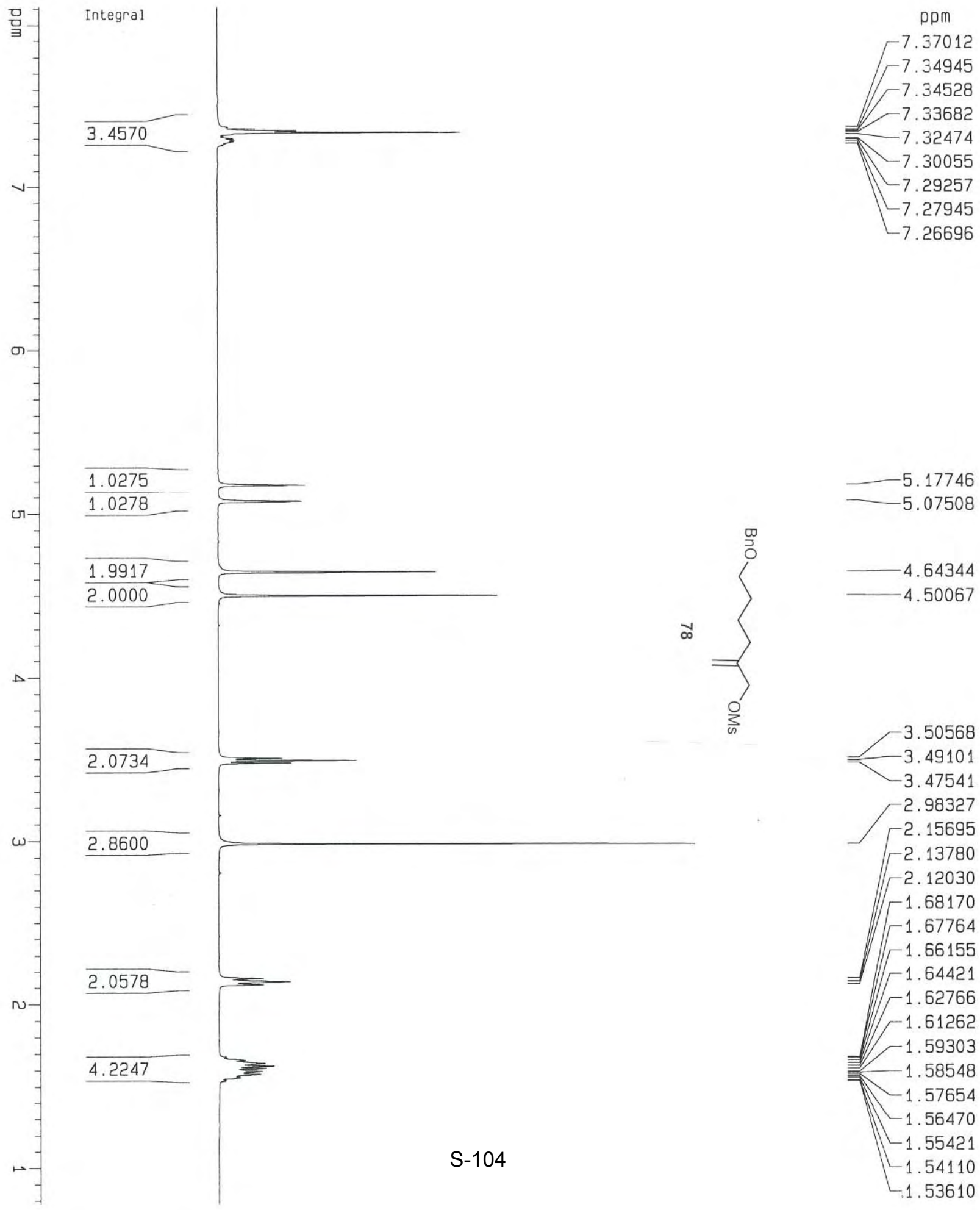




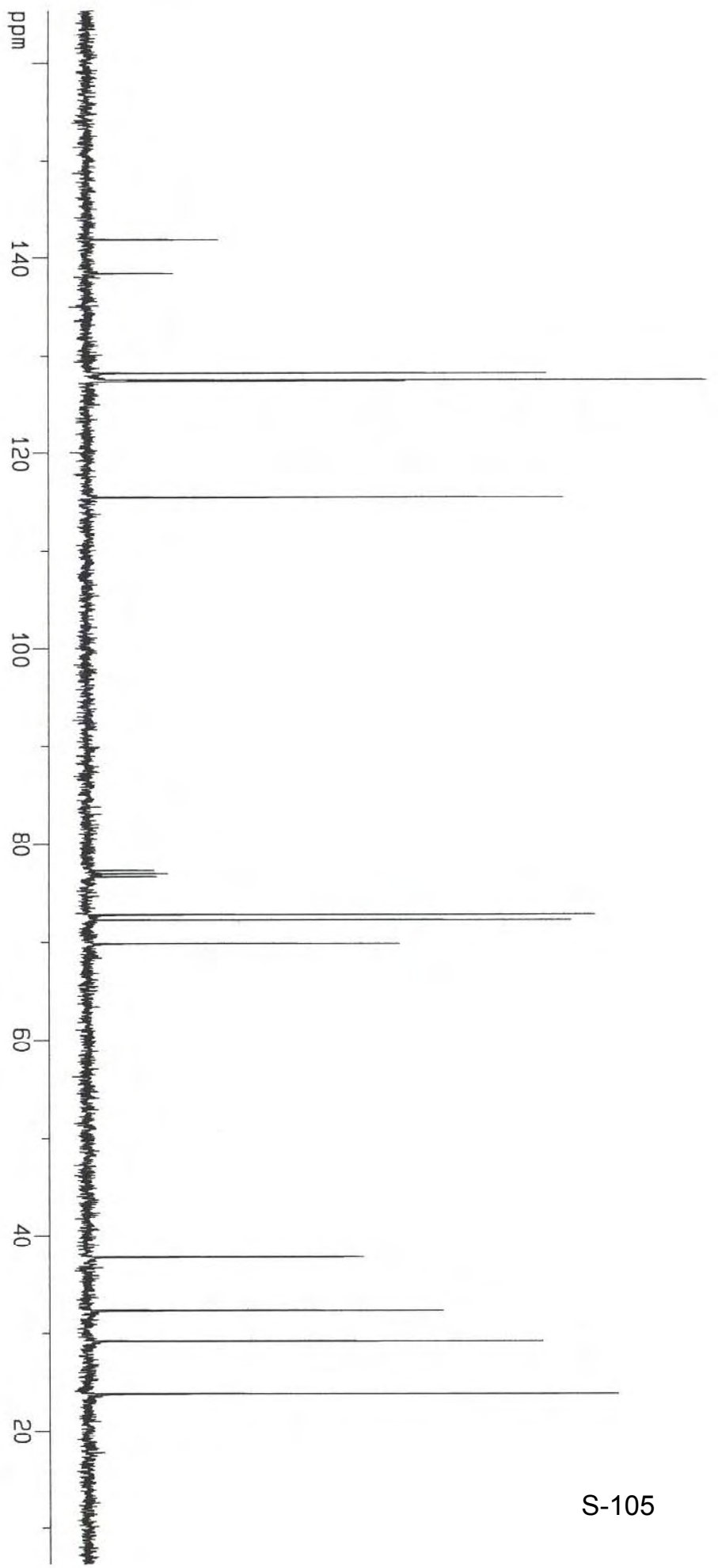

$-128.25$

$-127.53$

$-127.44$

$-115.42$
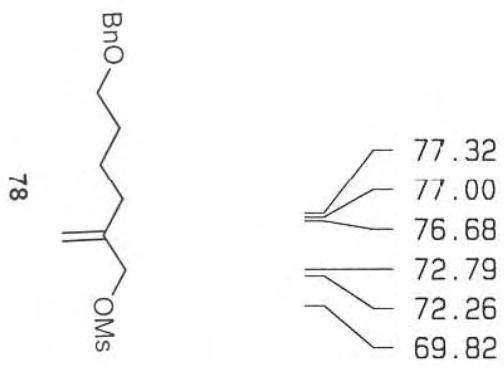

37.71

32.26

29.17

23.82 


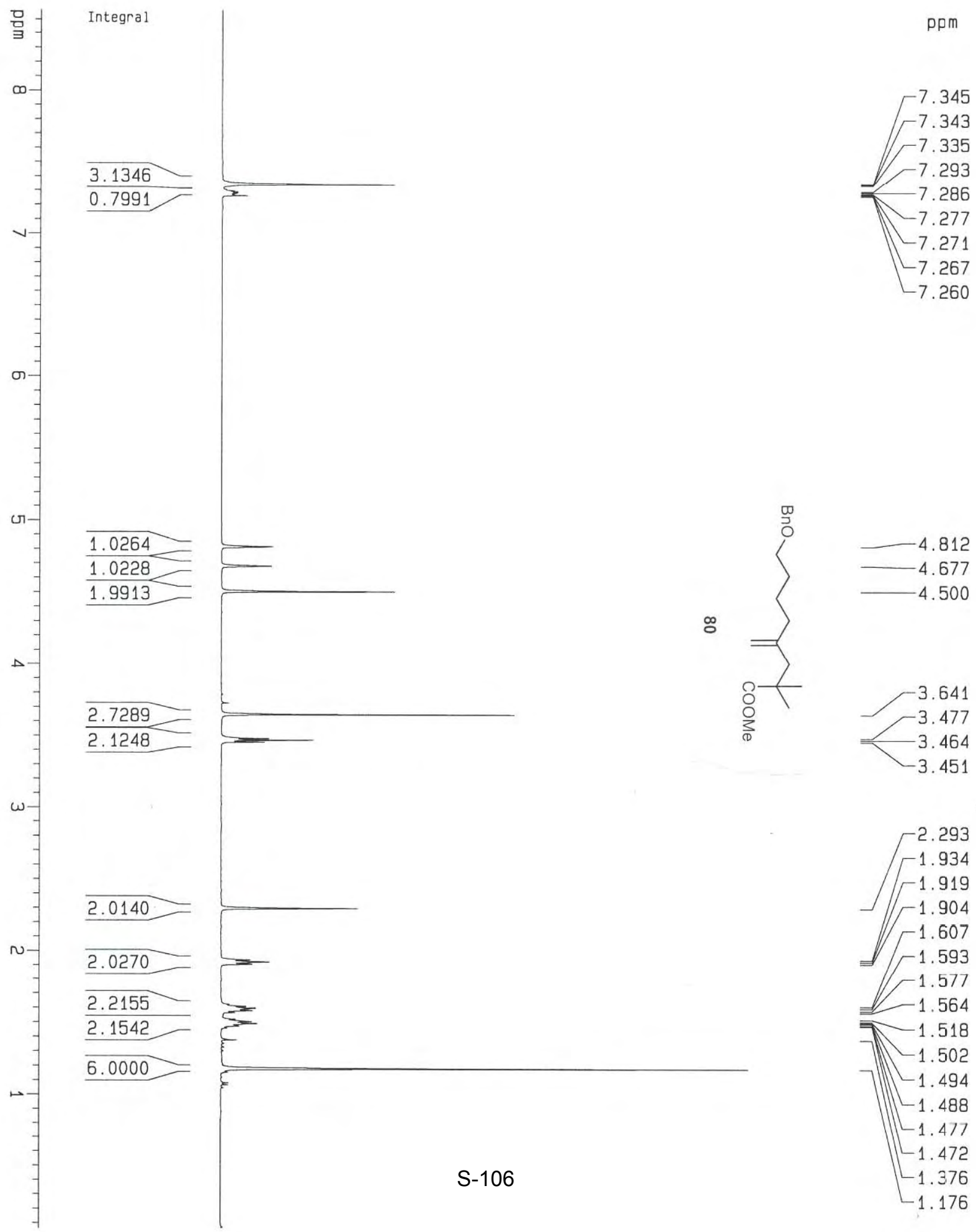



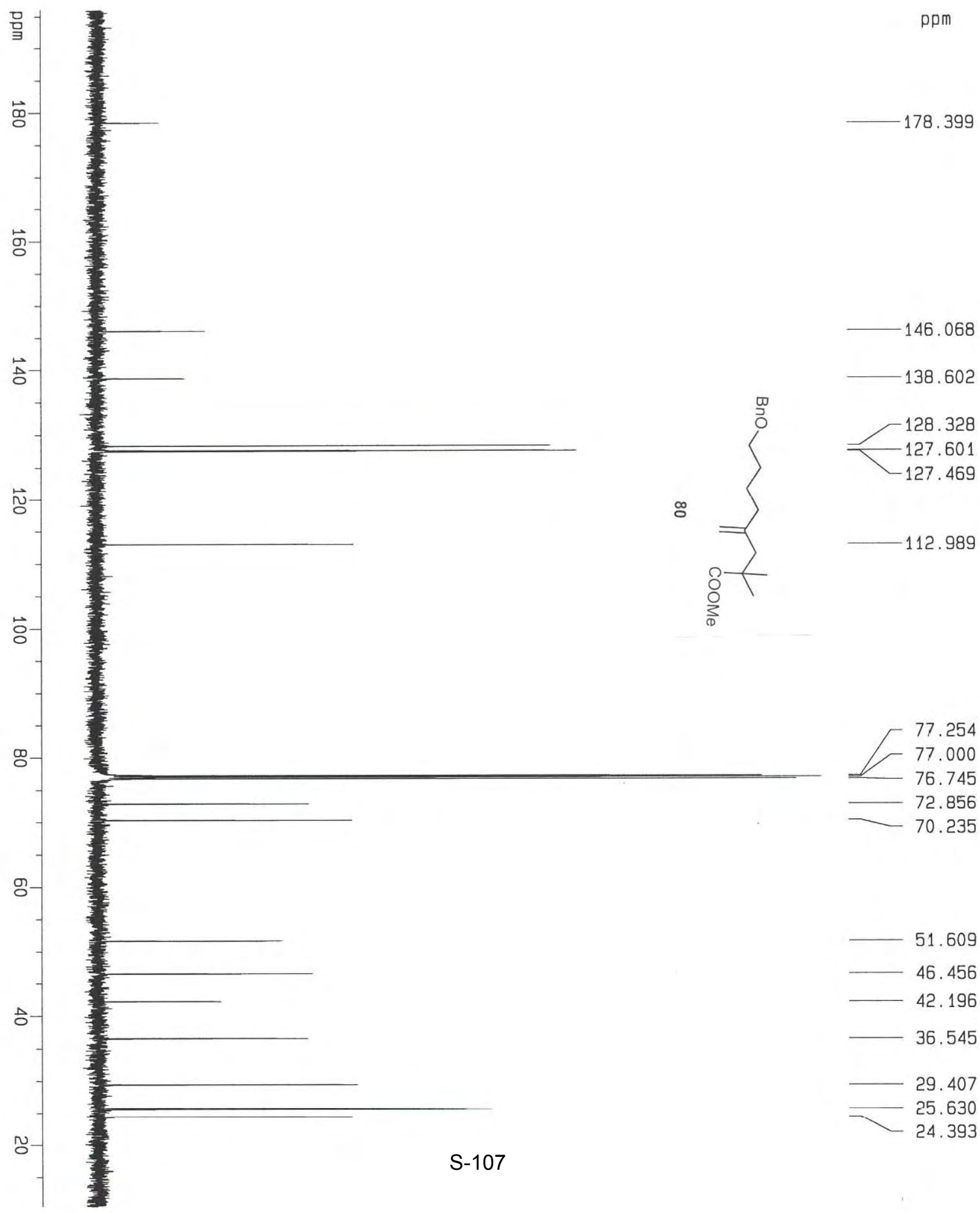


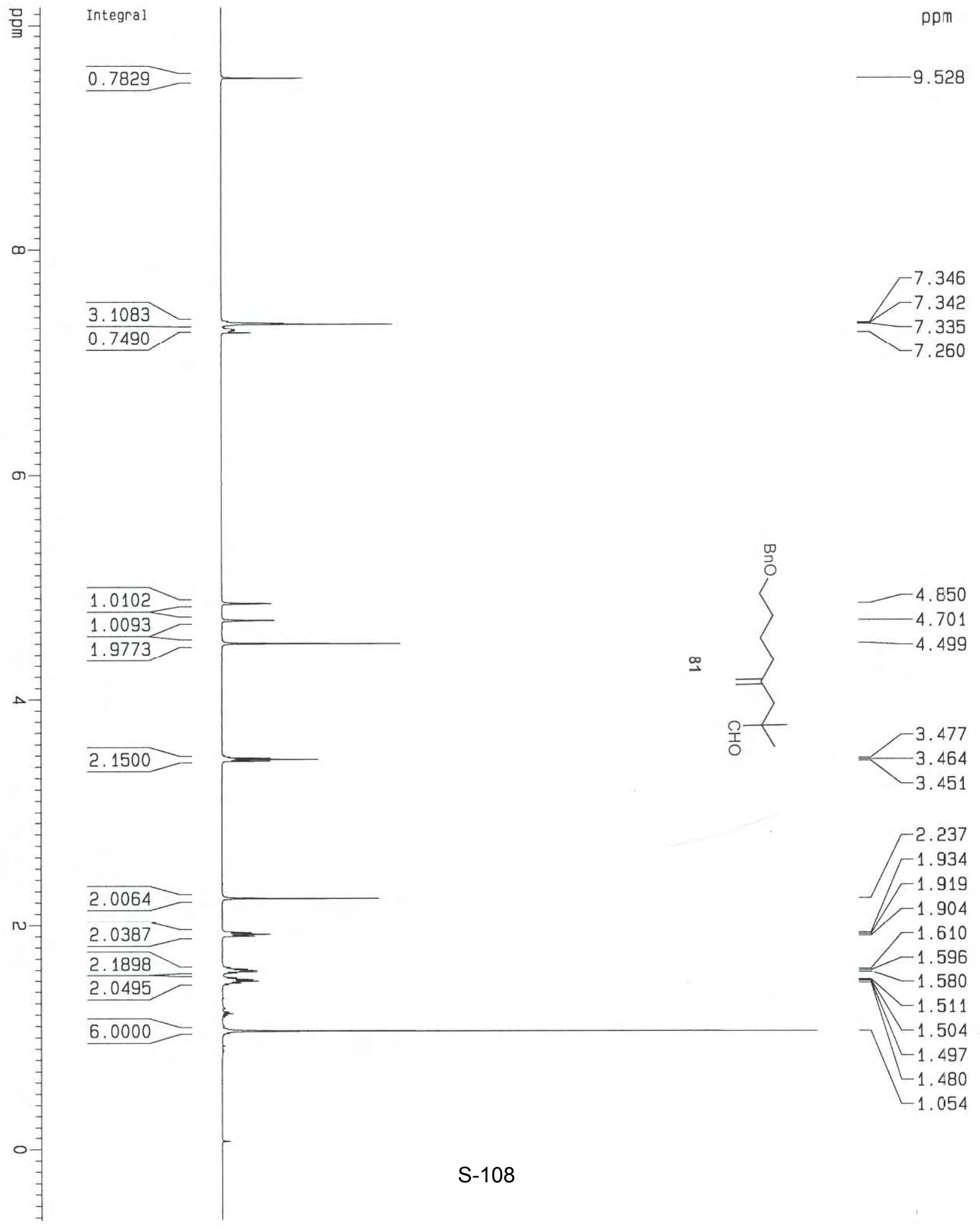




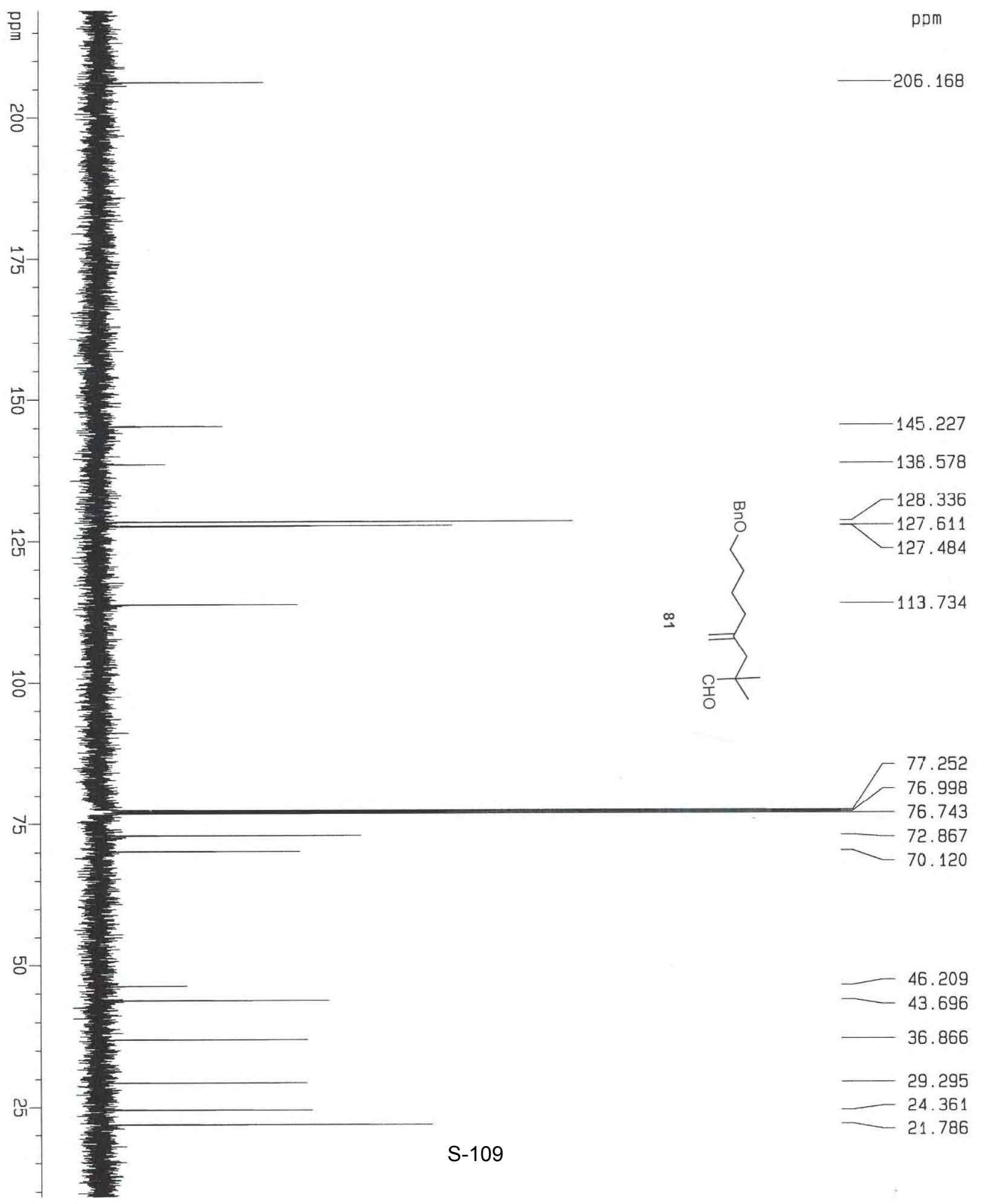




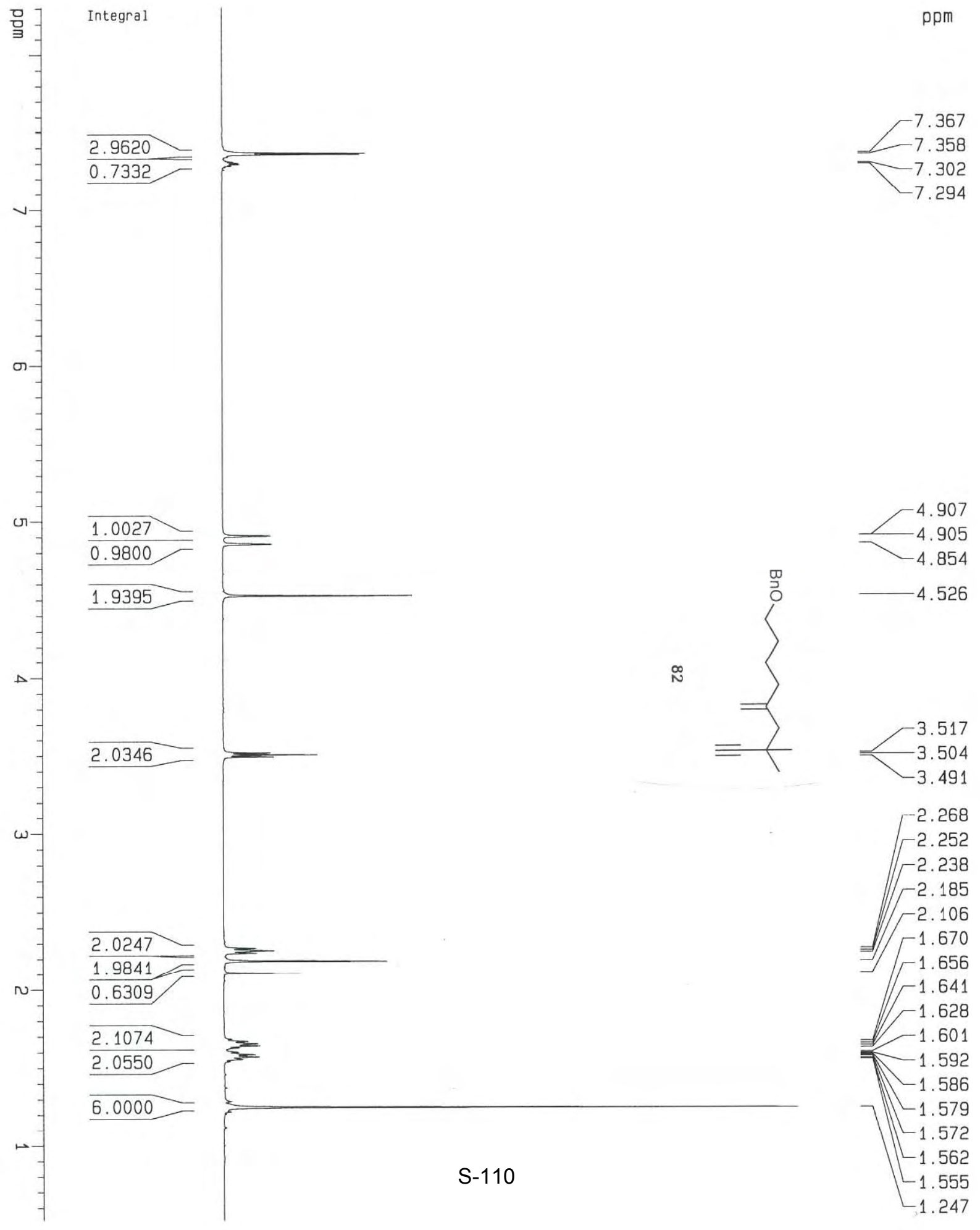



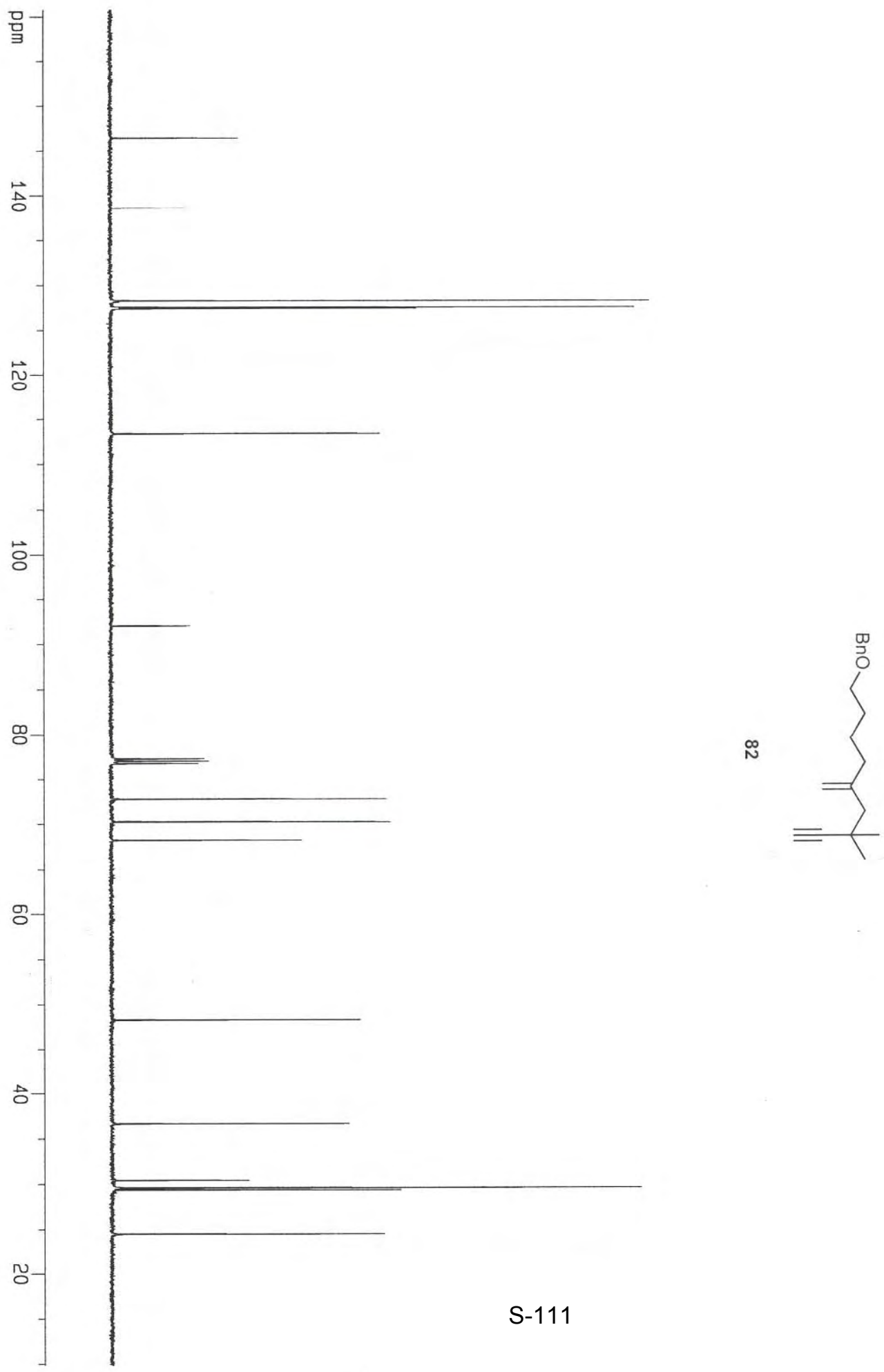

92.028 


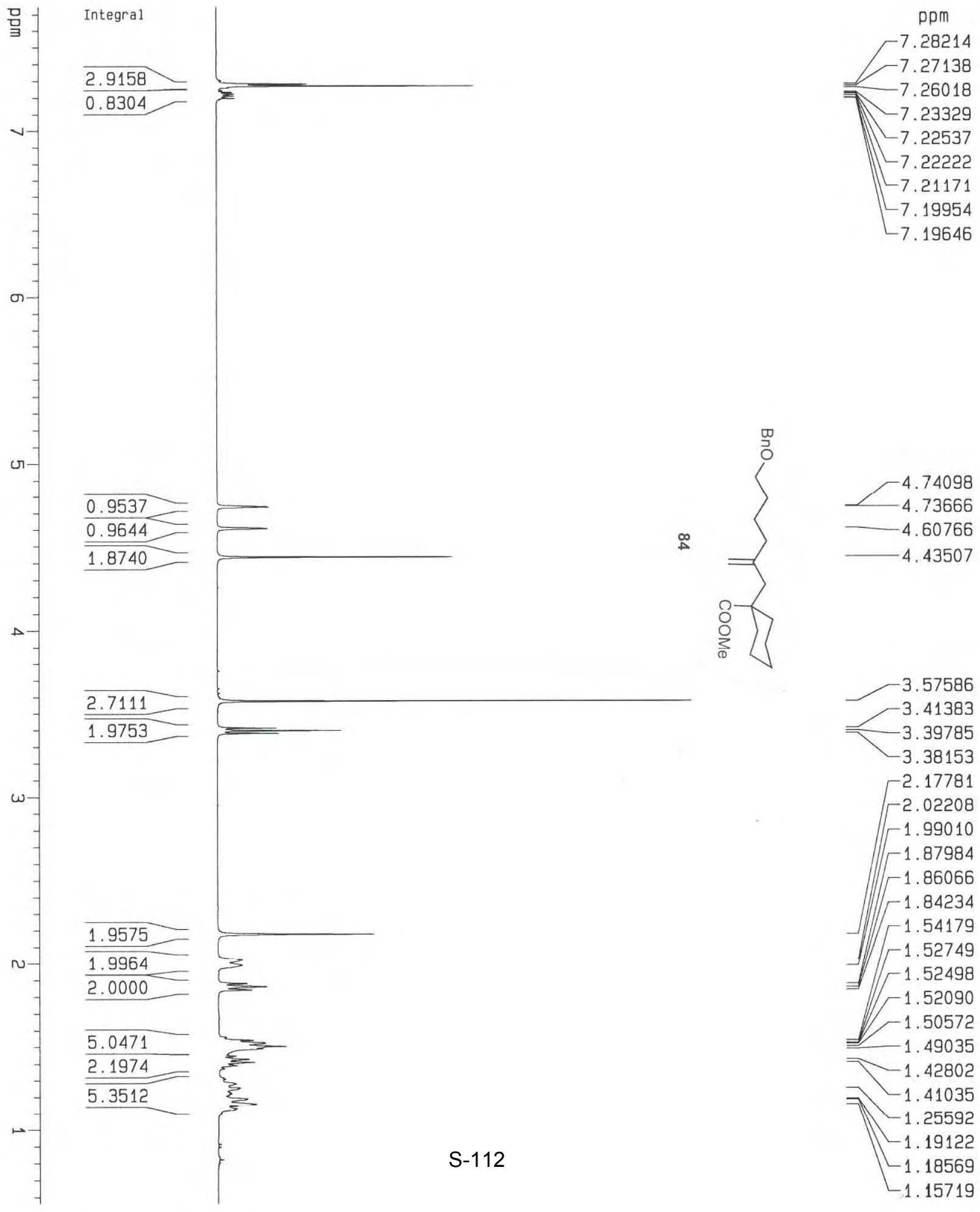


芩

-

ஃ

ø-

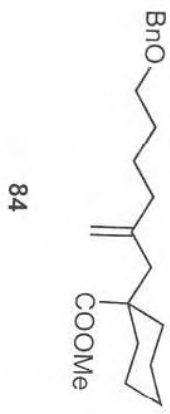

113.20

g

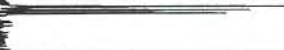

\夕

77.31

77.00

76.67

72.81

70.20

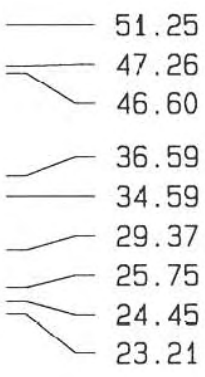




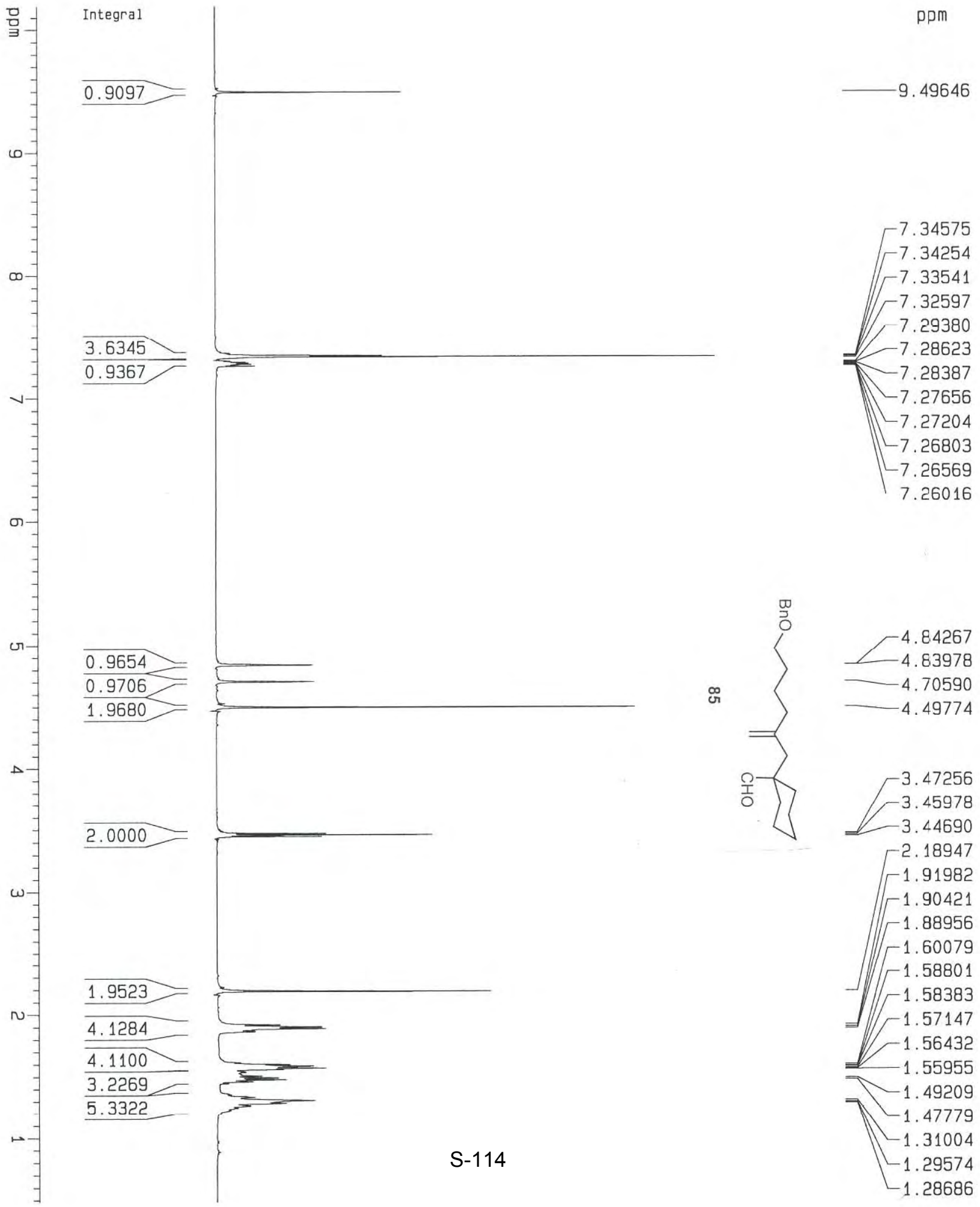




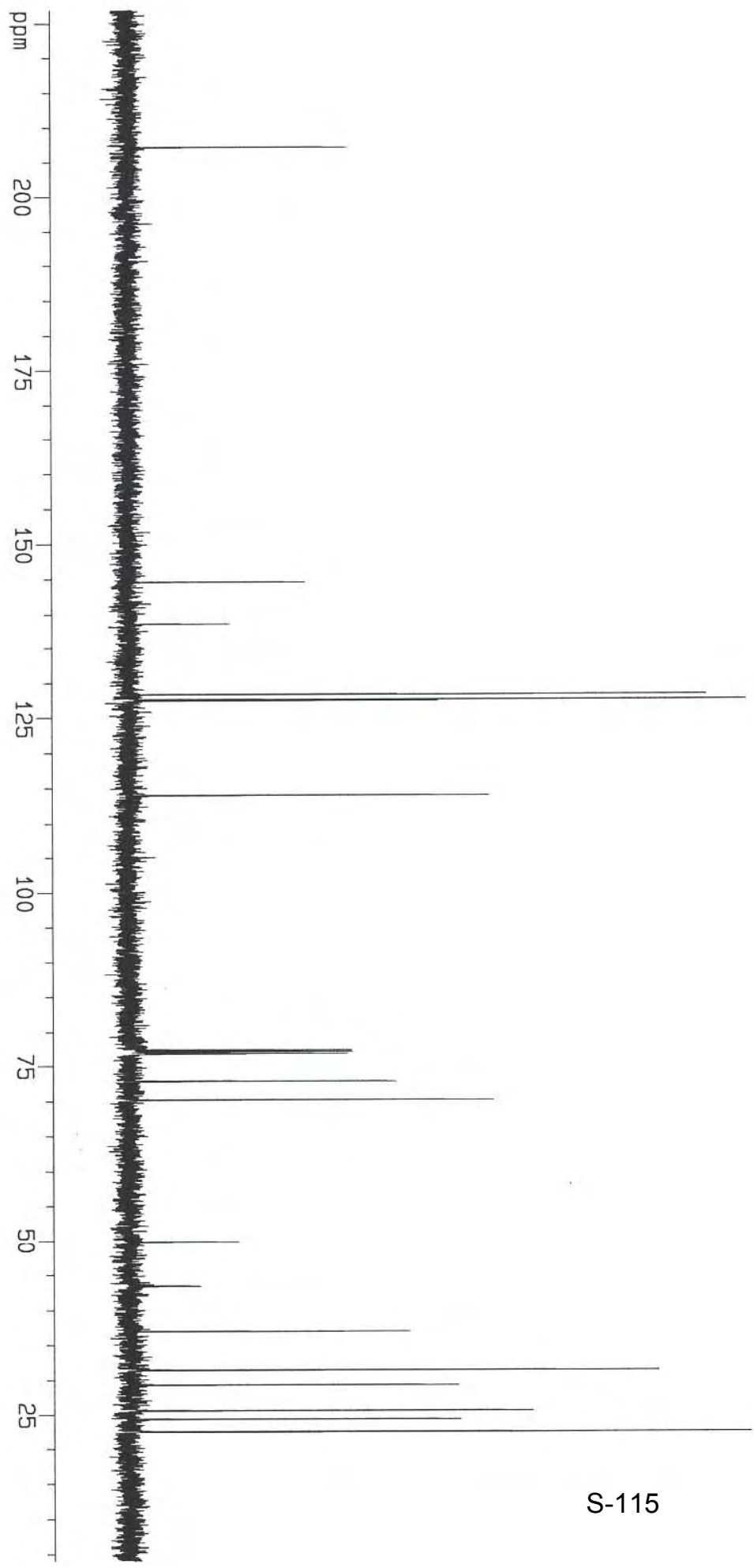




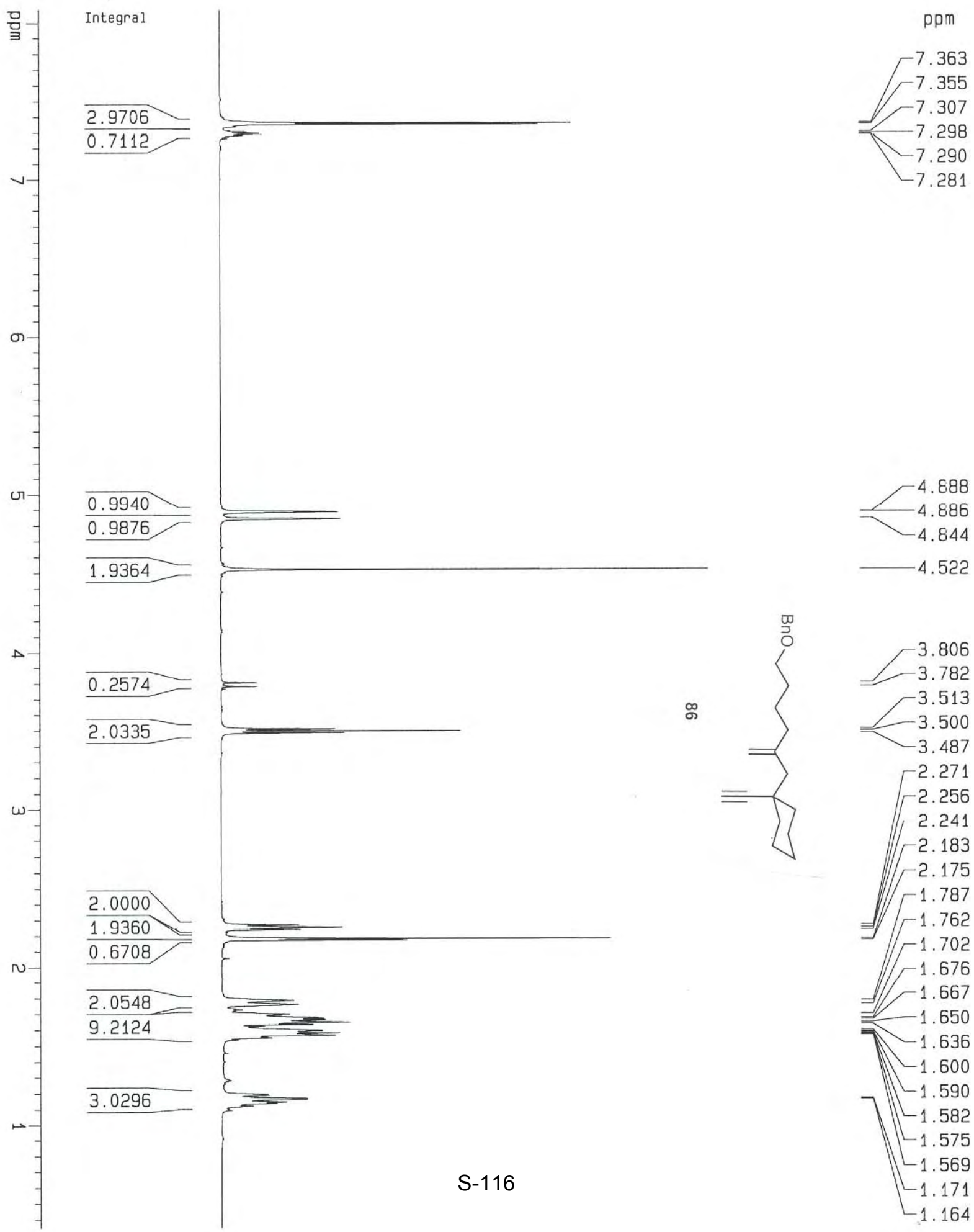




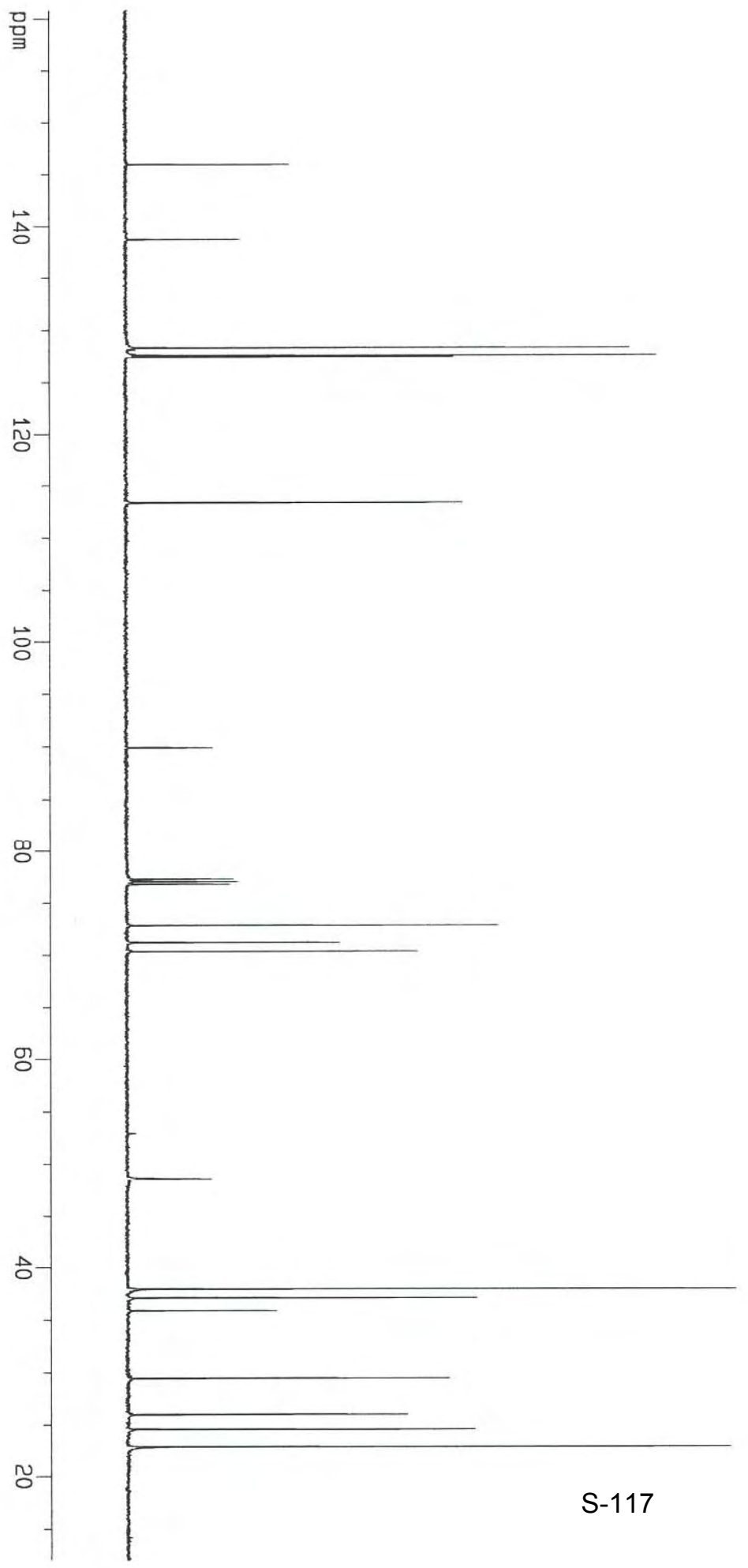



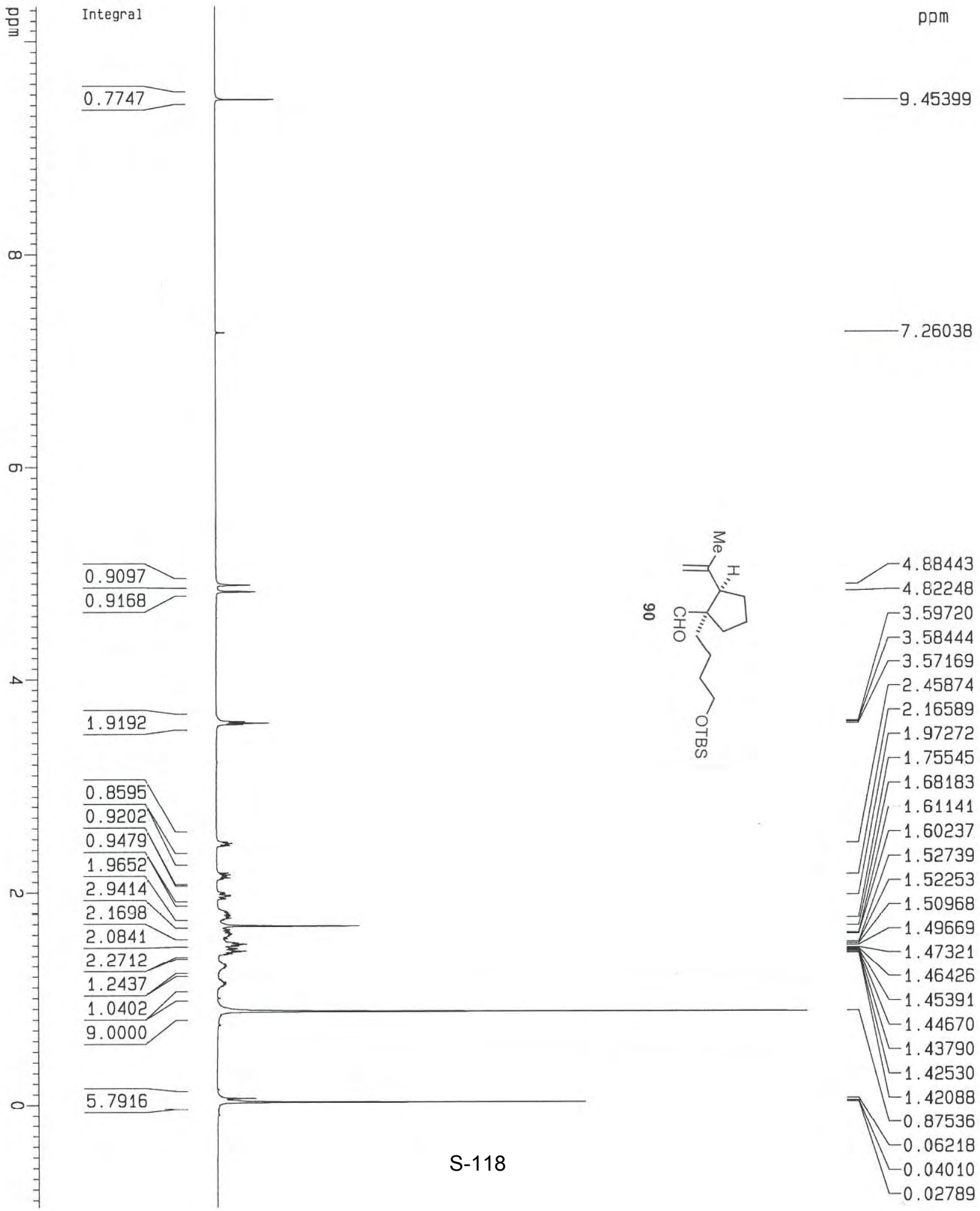


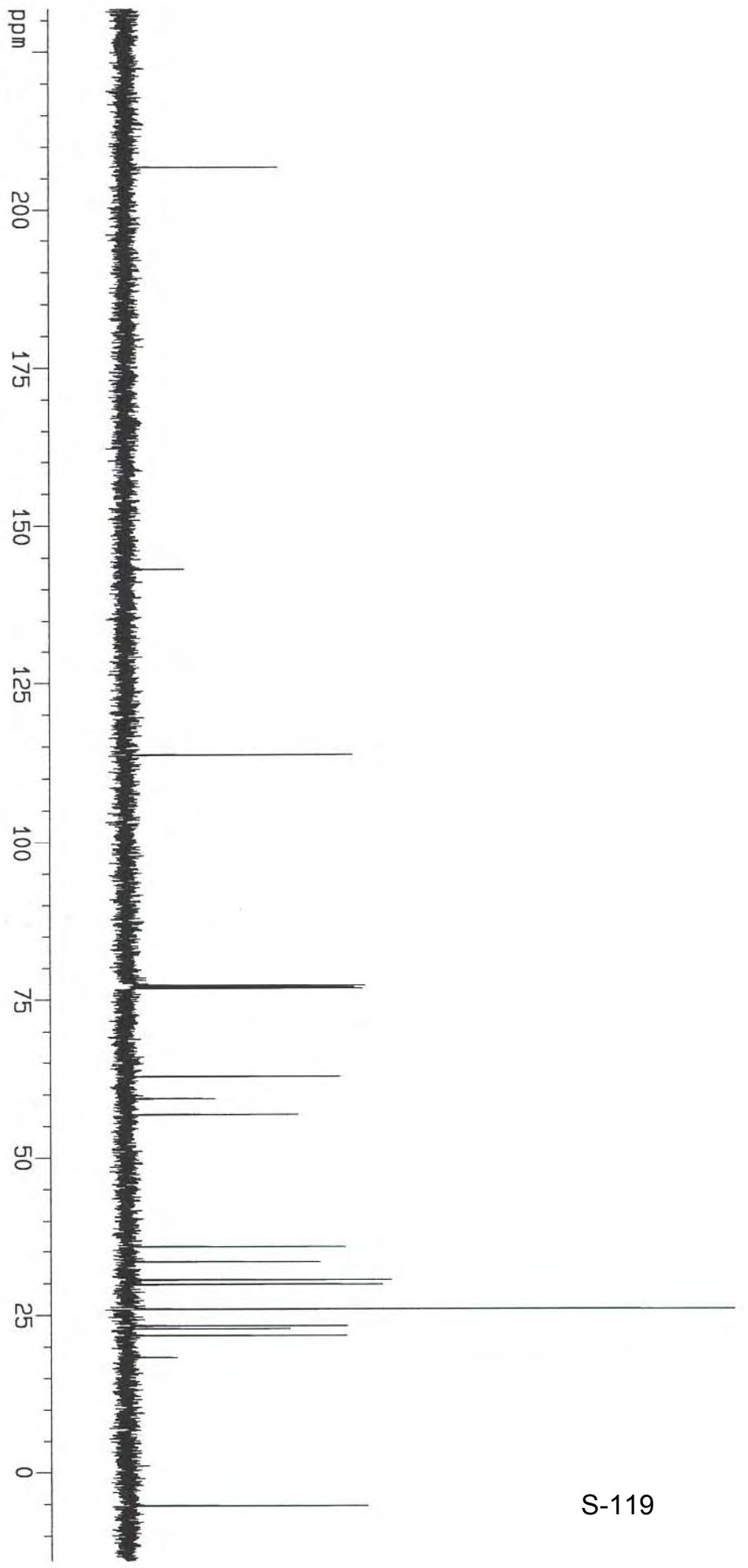

$-206.782$

$-143.122$

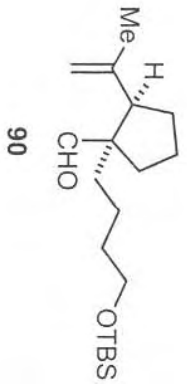

$-113.682$

77.250

76.997

76.743

62.738

59.322

56.772

35.731

33. 357

30.518

29.799

25. 918

23. 270

22. 774

21. 701

18. 297

$-5.315$ 


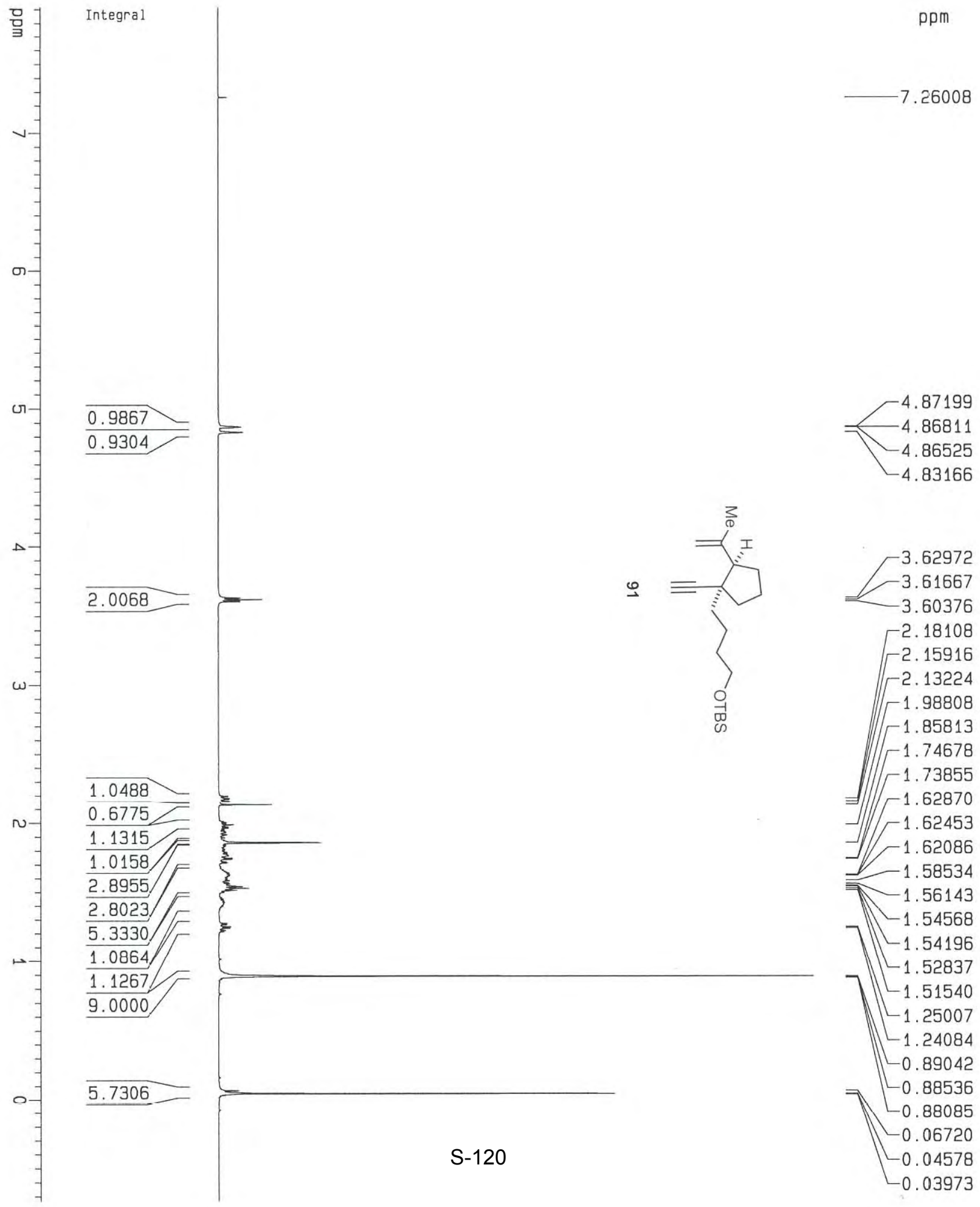



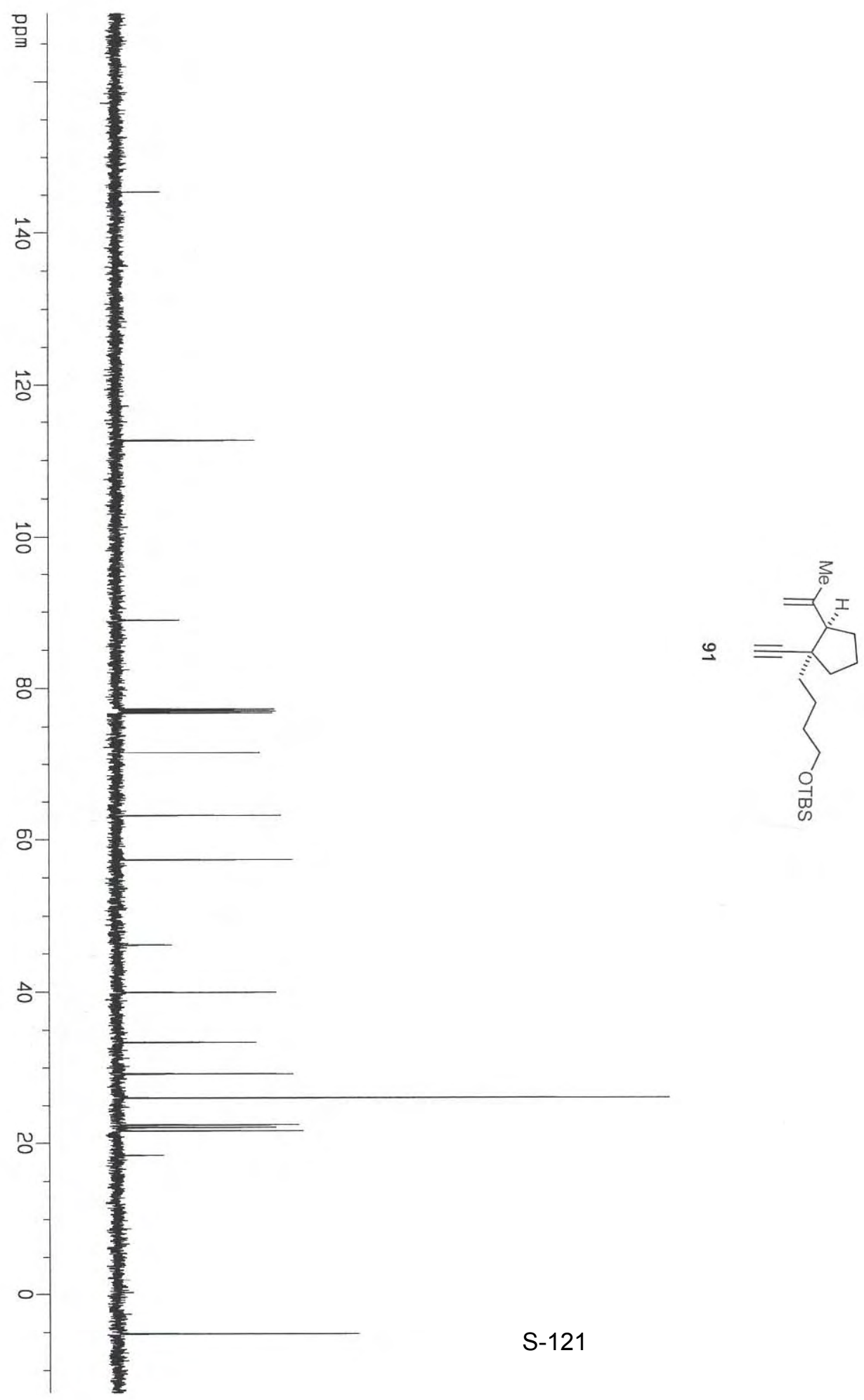